

\section{Ketergantungan \\ Masyarakat Dayak Terhadap \\ Hutan di Sekitar Taman \\ Nasional Kayan Mentarang}

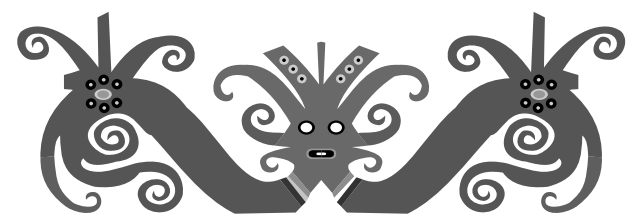

Asung Uluk

Orang Dayak Kenyah Leppo' Ké

dari Desa Long Tebulo, Kec. Pujungan,

Kab. Malinau Kalimantan Timur,

Peneliti di CIFOR dan sebelumnya di WWF

yang bertugas di Kabupaten Malinau selama 10 tahun

\section{Made Sudana}

Peneliti di CIFOR dan sebelumnya di WWF yang bertugas di Kabupaten Malinau selama 5 tahun

\section{Eva Wollenberg \\ Peneliti di CIFOR,}

mengepalai penelitian sosio ekonomi rumah tangga

di Kabupaten Malinau, sejak 1995

Kalimantan Timur 
(C) 2001 oleh Center for International Forestry Research Hak Cipta Dilindungi Undang-undang

Diterbitkan Tahun 2001

Dicetak oleh SMK Grafika Desa Putera, Indonesia

Sampul:

Foto sebelah kanan: Oko Bilung Lerang, Apau Ping - Eva Wollenberg Foto sebelah kiri: Ibu-ibu yang memakai baju tradisional dan mengumpulkan hasil hutan di Long Alango - Alain Compost

Fotografer

Eva Wollenberg

ISBN 979-8764-74-9

Diterbitkan oleh

Center for International Forestry Research (CIFOR)

Alamat Surat: P.O. BOX 6596 JKPWB, Jakarta 10065, Indonesia

Alamat Kantor: Jl. CIFOR, Situ Gede, Sindang Barang,

Bogor Barat 16680, Indonesia

Tel.: +62(251)622622; Fax: +62 (251) 622100

E-mail: cifor@cgiar.org

Web Site: Http://www.cifor.cgiar.org 


\section{Daftar Isi}

Pengantar ix

Ringkasan xi

Abstract xii

Bab 1. Pendahuluan 1

A. Orang Dayak di Sekitar Taman Nasional Kayan Mentarang $\quad 2$

B. Permasalahan yang Dialami Masyarakat 4

Bab 2. Peranan Hutan bagi Masyarakat Dayak di Sekitar Taman Nasional Kayan Mentarang

A. Hutan Merupakan Sumber Kebutuhan Pokok dan Ekonomi Masyarakat Dayak

1. Hutan Sebagai Sumber Bahan Makanan 8

2. Hutan Sebagai Sumber Obat-obatan 15

3. Hutan Sebagai Sumber Bahan Bangunan dan Perahu 16

4. Hutan Sebagai Sumber Pendapatan Uang Tunai 19

5. Hutan Sebagai Sumber Bahan Baku untuk Perlengkapan Kebutuhan Sehari-hari

B. Hutan Merupakan Kebutuhan Masyarakat Dayak secara Langsung dan Tidak Langsung

1. Ketergantungan Masyarakat Dayak terhadap Hutan untuk Memulihkan Kesuburan Tanah 
2. Ketergantungan Masyarakat Dayak terhadap Hutan sebagai Perlindungan Sumber Air

3. Ketergantungan Masyarakat Dayak terhadap Hutan sebagai Sumber Genetik Bibit Tumbuhan atau Binatang

4. Ketergantungan Masyarakat Dayak terhadap Ekosistem Hutan sebagai Hubungan yang Saling Terkait

\section{Bab 3. Keterkaitan Budaya Masyarakat Dayak terhadap Hutan}

A. Pengetahuan dan Keterampilan untuk

Memanfaatkan Hutan dan Mengelola Hutan

1. Di Hutan Tempat Mewariskan Ilmu Pengetahuan Tradisional

2. Keterampilan Orang Dayak dalam Berbagai Cara Berburu dan Menangkap Ikan

3. Keterampilan Orang Dayak dalam Mengelola Hutan

B. Hutan Sebagai Tempat untuk Mengambil Bahan-Bahan Upacara dan Kebudayaan

1. Bahan Upacara

2. Bahan Kebudayaan

3. Tari-tarian dan Lagu-lagu Meniru Kehidupan di Hutan

C. Simbol Status Sosial dan Nama-nama Orang Dayak Mengambil Contoh dari Hutan

1. Simbol Status Sosial

2. Nama-nama Orang Dayak Diambil dari Nama Binatang dan Tumbuhan Berdasarkan Status Sosial 

D. Hutan sebagai Tempat Berteduh dan Mencari Hiburan

\section{Bab 4. Pengaturan Hutan Berdasarkan Hukum Adat} Secara Lokal

A. Sifat Hukum Adat yang Tidak Statis Dibuat dengan Sistem Penyesuaian dengan Keadaan Baru

B. Hukum Adat Terhadap Hutan 81

C. Tana' Ulen di Hulu Bahau 84

1. Konsep Tana' Ulen 84

2. Asal Usul Konsep Tana' Ulen 86

3. Mencegah Konflik dari dalam Wilayah Desa dan Wilayah Adat 88

4. Mencegah Konflik dari Luar $\quad 89$

D. Sanksi-Sanksi Terhadap Pelanggaran Hukum Adat 90

E. Pengakuan Hutan Adat Berdasarkan UndangUndang Negara 91

Bab 5. Kesimpulan dan Rekomendasi Kebijakan 95

Catatan Kaki

Pustaka 103

Lampiran

1. Daftar Sumberdaya Alam yang Diperlukan oleh

Masyarakat di Sekitar Taman Nasional Kayan

Mentarang

2. Jumlah Jenis Hasil Bumi yang Dipanen Rata-rata Per KK Per Desa

3. Persen Jenis Hasil Bumi yang Dipanen Liar Rata-rata Per KK Per Desa 


\section{Daftar Foto}

1. Babi hutan dan dagingnya di L. Tebulo 9

2. Paku bai (Apau Ping) 11

3. Persiapan ubud bambu di Apau Ping 12

4. Kulat long 12

5. Bekkai yang siap untuk dipakai (L. Alango) 14

6. Kayu adau dijemur di hutan sebagai persiapan sebelum bangun rumah 18

7. Gaharu (sekau) (L. Alango) 20

8. Kayu manis (kayu me) di L. Alango 21

9. Mengumpulkan kayu api di Apau Ping 25

10. Orang yang siap berburu dengan bujak sambil pergi ke ladang (Apau Ping) 28

11. Pengumpulan uwai seka (rotan sega) di hutan (Apau Ping) 29

12. Tiga contoh belanyat dari hulu Bahau 30

13. Topi saung seling dan persediaan untuk anyaman (Apau Ping) 32

14. Membuat ma' lema' di Apau Ping 34

15. Ragi disimpan dalam daun sang dengan bawing sebagai pengawet $\quad 35$

16. Ibu-ibu memakai saung sambil cari ikan di L. Alango 36

17. Menambal perahu dengan damar (tu'dan) di Apau Ping 37

18. Ladang (uma) di L. Tebulo 39

19. Sungai Benuang yang tercemar oleh perusahaan batu bara (L. Loreh)

20. Dampak kemarau panjang pada hutan di L. Alango (Agustus 1990)

21. Uwai seka (rotan) yang diambil dari hutan untuk ditanam di kebun (Apau Ping)

22. Belanyat beta (kanan) dan sikep (kiri) 
23. Bading 64

24. Anting-anting dari kepala burung teba'un 70

25. Kulit kayu talun dipakai untuk membuat pakaian tradisional di L. Alango (25a dan 25b) 71

26. Kayu aing untuk membuat pewarna (Apau Ping) 71

27. Penari yang pakai besunung 72

28. Penari yang pakai topi dari bulu burung teba'un dan $\begin{array}{ll}\text { temengang } & 73\end{array}$

29. Kabuk di (a) balai desa dan (b) mandau 75 


\section{Pengantar}

Penulis mengucapkan terimakasih kepada semua pihak yang telah membantu dalam penulisan ini. Tim survei yang ke lapangan dan termasuk yang ikut merencanakan adalah Njau Anau, Asung Uluk, Irang Lawing, An Lenjau, Trivina Adjang, Yutang Bawan, Samuel S.T. Padan, Oktavianus Ramly, Yasan, Marten Markus, Edi Yanto Yusak, Simpson Aber, Dolvina Damus, Normanus Yusak, Godwin Limberg, dan Dr. Cristina Eghenter dari WWF Kayan Mentarang, dan Ani Nawir, Ambar Liano, dan Dr. Lini Wollenberg dari CIFOR. Penelitian tindak lanjut dilakukan oleh Asung Uluk dan Dr. Lini Wollenberg dari CIFOR. Data tambahan untuk melengkapi tulisan ini dikumpulkan oleh Asung Uluk dari CIFOR dan Made Sudana dari WWF Kayan Mentarang. Bantuan transportasi dan logistik diberikan oleh Daud Lalo, Ingan Njuk, Ishak Baya, Jan Jalung, Lukas Bilung, dan Bilung Laing dari WWF Kayan Mentarang.

Nama lokal jenis tumbuhan dalam tulisan ini dibantu oleh Uluk Apui dan Bay Bilung dari Long Tebulo. Nama jenis burung dan binatang oleh Ingan Njuk dari Long Tebulo dan Irang Lawing dari Apau Ping. Nama ilmiah jenis tumbuhan dicocokkan berdasarkan spesimen herbarium WWF Kayan Mentarang yang dibuat oleh Daud Lenjau, Ingan Njuk, Irang Lawing, Laing Alang, Balan Njau, Made Sudana, dan Dr. Rajindra K. Puri. Spesimen herbarium ini diidentifikasikan oleh Ambriansyah dan Zainal Arifin dari Wanariset Samboja, Samarinda. Beberapa jenis tumbuhan diidentifikasikan oleh Apriastini dari LIPI. Tambahan nama ilmiah tumbuhan berdasarkan 
koleksi dari Long Tebulo oleh Dr. Mary C. Stockdale dan Jonathan Corbett dari University of Oxford, Inggris. Penulisan nama ilmiah jenis tumbuhan diperiksa oleh Dr. Kade Sidiyasa dari Wanariset Samboja, Samarinda. Nama jenis ikan berdasarkan koleksi WWF Kayan Mentarang yang dilakukan oleh Swiki dan Limbong bersama Dr. Soetikno Wirjoatmodjo dari LIPI. Tambahan nama ikan oleh Ike Rachmatika Budiawan dari LIPI. Nama reptil dibantu oleh Dr. Djoko Iskandar dari Institut Teknologi Bandung. Penulisan nama lokal dan nama ilmiah dicek kembali dengan penulisan oleh Dr. Rajindra K. Puri dalam buku Bulungan Ethnobiology Handbook (2001)1. Selain itu juga dicocokkan berdasarkan buku PROSEA sebagai referensi.

Data tambahan mengenai asal usul Taman Nasional Kayan Mentarang dibantu oleh Dr. Cristina Eghenter. Cerita tentang kebudayaan diberikan oleh Oko Dan Udau dan Bay Bilung dari Long Tebulo dan Njau Anau dari Long Alango. Hukum adat dan asal-usul tana' ulen diberikan oleh Drs. Ajang Kahang dari Long Uli dan Bpk. Anyi'e Apui, Kepala Adat Besar Hulu Sungai Bahau. Cerita tentang perkembangan ladang, sawah, kolam, pemeliharaan babi hutan, dan pembangkit listrik oleh Bpk. Ajang Apui dan Bpk. Jan Lawai dari Long Alango. Terimakasih kepada semua nara sumber di desa-desa yang tidak bisa disebutkan satu per satu.

Penulis juga mengucapkan terimakasih sebesar-besarnya kepada Dr. Kuswata Kartawinata, Dr. Herwasono Soedjito, Suwito, Godwin Limberg dan Ba'un Uluk yang telah memberi masukan dan menyunting tulisan ini. 


\section{Ringkasan}

Di Indonesia, meningkatnya perusakan hutan mempengaruhi akses masyarakat lokal atas hutan, tetapi hanya sedikit informasi yang tersedia mengenai dampak perusakan hutan terhadap masyarakat yang punya ketergantungan yang tinggi pada hutan. Untuk lebih memahami dampak potensial ini, di sini kami melaporkan mengenai penggunaan hutan dari segi ekonomis dan budaya di tiga desa di Kecamatan Pujungan, Kalimantan Timur, dengan menggunakan data hasil survei rumah tangga yang dilaksanakan tahun 1996. Kami menunjukkan bagaimana kelompok suku lokal Kenyah sangat tergantung pada hutan untuk makanan, obat, pembangunan, pendapatan rumah tangga, juga untuk mempertahankan sumber daya alam seperti air dan kesuburan tanah, dan sebagai sumber dari simbol kebudayaan, bahkan untuk pemberian nama-nama bagi anggota keluarga. Kami menunjukkan keterkaitan antara hutan dengan budaya Kenyah dan mempelajari aturan lokal mengenai penggunaan sumber daya hutan, termasuk konsep tana' ulen. Studi ini menyimpulkan bahwa walaupun ada kebijakan yang memungkinkan pengelolaan hutan oleh adat, kebijakan ini tetap harus diaplikasikan secara formal di wilayah hutan tersebut. Apabila masyarakat lokal belum merasa aman mengenai hak mereka atas tanahnya, cara hidup mereka, yang sangat tergantung pada keberadaan hutan, masih sangat berisiko. 


\section{Abstract}

In Indonesia, rapid deforestation is affecting local populations' access to forest, yet little information is available about the impacts of deforestation on highly forest-dependent populations. To better understand these potential impacts, we report here on economic and cultural uses of the forest for three villages in the Sub-District of Pujungan in East Kalimantan, using data from household suveys conducted in 1996. We show how local Kenyah groups depend on forests for food, medicine, constuction, cash income, as well as to maintain natural resources such as water and soil fertility, and as a source of cultural symbols and even people's names. We show the linkages of the forest to Kenyah culure and review local rules of use of forest resources, including the concept of tana' ulen. The study notes that despite policies making customary management of forest possible, these policies have yet to be formally applied in area. Until the local communities feel more secure about their rights to land, their way of life, which depends so very much on the forest, is at risk. 


\section{Bab 1}

\section{Pendahuluan}

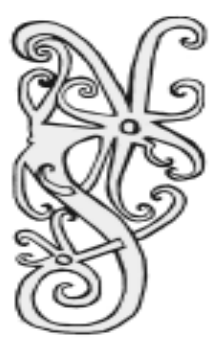

Konversi hutan untuk berbagai kepentingan telah memusnahkan jutaan hektar hutan, terutama setelah keadaan Otonomi Daerah. Pembukaan hutan oleh pemegang IPPK (Izin Pemungutan dan Pemanfaatan Kayu), HPH (Hak Pengusahaan Hutan), perkebunan, pertambangan, dan konversi untuk kepentingan lain telah mendesak para pengelola tradisional yang mendiami wilayah tersebut selama ratusan tahun. Wilayah mereka menjadi semakin sempit, sumber daya alam berkurang, sedangkan kehidupan mereka di bidang pembangunan ekonomi kurang mendapat perhatian.

Sebagian besar masyarakat di Indonesia belum mengetahui ketergantungan masyarakat asli yang mendiami wilayah di pedalaman terhadap hutan, yang merupakan hubungan timbal balik secara harmonis atau selaras. Misalnya, di sekitar Taman Nasional (TN) Kayan Mentarang di Kabupaten Malinau dan Nunukan, Kalimantan Timur, ada sekitar 25.000 penduduk yang hampir semua kebutuhan mereka, termasuk makanan, bahan bangunan, obat, pendapatan tunai, sumber air dan budaya mereka sangat tergantung pada hutan. Tulisan ini dimaksudkan untuk menjelaskan ketergantungan masyarakat asli terhadap hutan, dan pengaruh desakan dari pihak luar sehingga dapat dimengerti dampak kerusakan hutan terhadap kehidupan masyarakat lokal. Di samping itu juga untuk memberi masukan kepada kebijakan 
pemerintah guna mengatasi atau mencegah masalah dan konflik. Kami jelaskan ketergantungan masyarakat dari aspek ekonomi maupun budaya.

Tulisan ini berdasarkan hasil penelitian sosio ekonomi rumah tangga yang merupakan kerjasama CIFOR dan World Wide Fund for Nature - Indonesia Programme pada tahun 1995-96, dan penelitian tindak lanjut sampai tahun 1998, yang telah dilakukan di sekitar TN Kayan Mentarang. Kegiatan penelitian ini dilakukan di tiga kecamatan yang berada di dalam atau sekitar TN Kayan Mentarang yaitu Kecamatan Kerayan, Mentarang, dan Pujungan. Metode yang dipakai termasuk survei rumah tangga (memakai random sampling), wawancara responden utama, dan pengamatan langsung. Laporan ini terfokus pada hasil dari tiga desa di Kecamatan Pujungan yaitu: Long Pujungan dengan 47 Kepala Keluarga (KK), Long Alango $40 \mathrm{KK}$, Apau Ping $32 \mathrm{KK}$, karena penulis paling lama melakukan penelitian di daerah ini dan juga terdapat lebih banyak data pendukung (lihat peta 1). Untuk hasil lain dari penelitian ini dan penjelasan metode, lihat Wollenberg et al. 2001, Uluk dan Wollenberg 1998, Wollenberg dan Uluk 1998. Angka-angka yang dilaporkan di sini adalah jumlah atau prosentase per desa dari tiga desa tersebut.

\section{A. ORANG DAYAK DI SEKITAR TAMAN NASIONAL KAYAN MENTARANG}

Orang Dayak di sekitar TN Kayan Mentarang terdiri dari berbagai subsuku Dayak antara lain: Kayan, Kenyah, Lundayeh, Merap, Punan, Saben, Tagel, dan lain-lain. Mereka adalah pengelola hutan yang bijak, yang telah mengelola hutan selama berabad-abad tanpa menimbulkan kemusnahan hutan, sehingga sampai sekarang kawasan hutan seluas 1,4 juta ha yang ditetapkan sebagai TN Kayan Mentarang masih utuh. Sistem pengelolaan yang diterapkan secara turun-temurun mewariskan hutan utuh yang dapat dinikmati oleh anak cucu mereka pada generasi sekarang. Berdasarkan hasil penelitian ini, dan pengalaman salah seorang penulis penduduk asli setempat (selama 
PENDAHULUAN

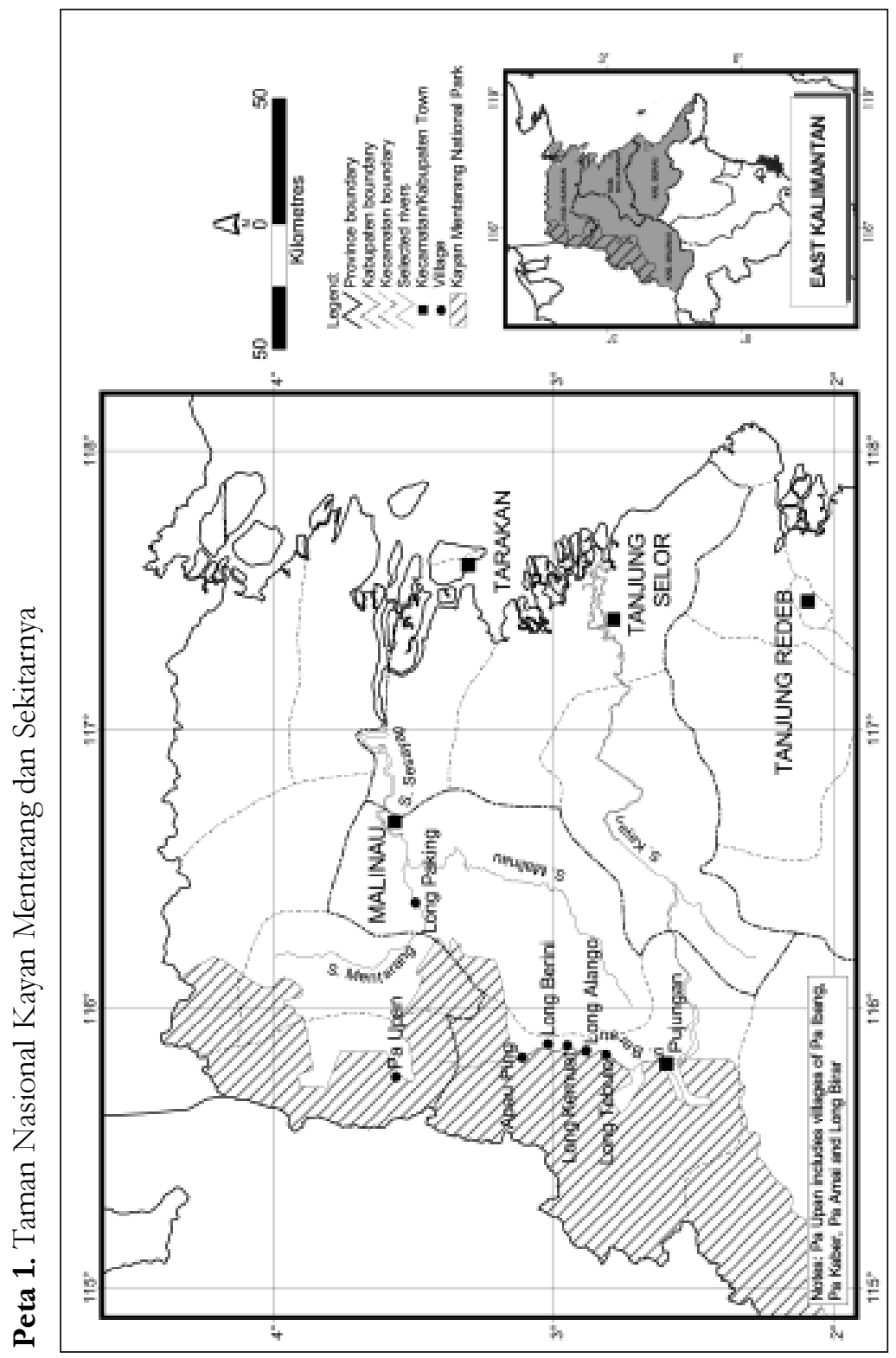


28 tahun), hampir seluruh hidup orang Dayak di sekitar TN Kayan Mentarang tergantung pada hutan. Kehidupan masyarakat tidak dapat dipisahkan dengan hutan. Untuk informasi mengenai sejarah Hulu Bahau, lihat Sellato (2001), Anau (1999), Eghenter dan Sellato (1999).

Hasil hutan bukan hanya merupakan pendapatan sampingan, tapi hubungan antara hutan dan masyarakat Dayak di sekitar TN Kayan Mentarang bagaikan air dengan ikan. Ikan tidak bisa hidup tanpa air, ikan bernafas dan mencari makanan dalam air. Begitu pula bagi orang Dayak di sekitar TN Kayan Mentarang, mereka tidak bisa hidup tanpa hutan yang lestari. Mereka memenuhi hampir semua kebutuhan pokoknya dari dalam hutan.

Tradisi dan budaya masyarakat Dayak sangat berkaitan dengan hutan. Orang Dayak mengambil bahan upacara yang berasal dari hutan. Nama-nama orang Dayak diambil dari nama-nama binatang maupun tumbuh-tumbuhan di hutan. Mereka mencari nafkah dengan cara menirukan kehidupan binatang untuk mengelabui binatang buruannya di hutan.

Berkenaan dengan adanya kemarau panjang tahun 1997-98 yang menyebabkan panen gagal dan sulitnya transportasi melalui sungai telah menyebabkan persediaan barang sangat berkurang. Ditambah lagi adanya krisis moneter yang mengakibatkan harga barang yang membumbung naik, telah menyebabkan orang Dayak lebih menggantungkan diri pada hasil hutan.

\section{B. PERMASALAHAN YANG DIALAMI MASYARAKAT}

Kehidupan masyarakat asli yang sangat tergantung pada hutan sekarang terancam oleh persaingan lahan dan konflik atas hutan untuk berbagai kepentingan pembangunan. Pemanfaatan lahan di bidang pertambangan, eksploitasi hutan atau penebangan kayu, perkebunan intensif, dan lain-lain telah menghasilkan devisa bagi negara. Di lain pihak, kepentingan para investor telah menguasai sebagian besar lahan dan menyudutkan para petani ekonomi lemah ke wilayah yang sempit, terbatas, dan tertinggal. Pengambilan hasil bumi dalam sekala besar 
juga telah mengakibatkan pencemaran, air keruh, dan limbah kotor yang menjadi bagian untuk penduduk asli.

Politik pembangunan telah merugikan hak-hak adat dan pengelolaan secara lokal baik di bidang ekonomi, maupun sosial dan budaya yang mengakibatkan cepatnya sistem dan pola kehidupan masyarakat adat hancur. Hak-hak masyarakat adat dikorbankan untuk pembangunan yang terutama dinikmati kaum elit. Desakan dan intimidasi telah membingungkan sebagian besar warga yang tinggal di pelosok-pelosok.

Sejak adanya reformasi dan kebijakan desentralisasi, ada perdebatan mengenai siapa yang seharusnya mempunyai hak atas kawasan hutan dan siapa yang mendapat hak untuk mengelola hutan. Salah satu konsep hutan kemasyarakatan yang dikenal dengan istilah tana' ulen telah dibahas dalam lokakarya tahun 1998 di Tanjung Selor. Konsep tana' ulen ini dipakai sebagai landasan untuk meningkatkan keterlibatan masyarakat lokal dalam pengelolaan hutan. Kebijakan kehutanan terhadap tana' ulen diperlukan oleh masyarakat lokal untuk mendapatkan kepastian hak atas tanah, hutan, dan kekayaan di dalamnya agar dapat dikelola secara mandiri berdasarkan aturan adat yang disetujui oleh pemerintah. Kebijakan mengenai tana' ulen bisa menjadi upaya alternatif atau inovatif untuk menghindari dan mencegah konflik dalam penggunaan lahan dan hak atas tanah. 


\section{Bab 2}

\section{Peranan Hutan bagi Masyarakat Dayak di Sekitar Taman Nasional Kayan Mentarang}

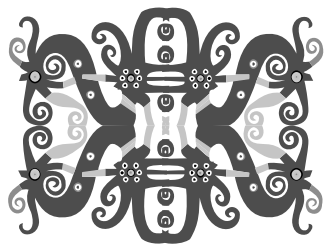

Dalam tulisan ini diuraikan peranan hutan bagi masyarakat Dayak di sekitar TN Kayan Mentarang yang meliputi kebutuhan jenis tumbuhan, binatang, serangga, ikan, jamur, dan lainlain. Contoh-contoh yang disebutkan dalam tulisan ini merupakan jenis-jenis yang paling umum dipakai oleh masyarakat. Jenis-jenis lainnya dapat dilihat dalam Lampiran 1. Lihat juga Puri (2001) untuk penjelasan jenis tumbuhan dan binatang yang dipakai oleh masyarakat setempat. Jenis hasil hutan yang disebutkan termasuk yang berasal dari hutan primer maupun sekunder. Jenis tumbuhan dari tanaman pertanian dan hewan peliharaan dibahas sebagai pembanding. Jumlah jenis hasil bumi yang dipanen diringkas per golongan dalam Lampiran 2 dan 3. Semua nama lokal jenis tumbuhan dan binatang yang dipakai adalah dalam bahasa Dayak Kenyah Leppo’ Ké. ${ }^{2}$

\section{A. HUTAN MERUPAKAN SUMBER KEBUTUHAN POKOK DAN EKONOMI MASYARAKAT DAYAK}

Hasil penelitian ini menunjukkan bahwa masyarakat Dayak di sekitar TN Kayan Mentarang sangat tergantung pada berbagai jenis hasil hutan. Berdasarkan hasil perhitungan data tercatat sebanyak 139 
sampai 214 jenis hasil hutan yang dimanfaatkan untuk berbagai kepentingan dalam waktu satu tahun (1995-96), antara lain sebagai sumber makanan, obat, bahan bangunan, sumber penghasilan uang tunai, upacara dan kebudayaan. Jumlah ini hanya sebagian-mungkin 25 persen - dari semua jenis hasil hutan yang mereka kenal. Jenis tumbuhan yang berasal dari tanaman pertanian sekitar 23 sampai 35 jenis atau hanya sekitar $11 \%$ sampai $25 \%$ dari jumlah semua hasil bumi yang dipakai.

\section{Hutan Sebagai Sumber Bahan Makanan}

\section{a. Di hutan diperoleh protein dari berbagai jenis binatang, serangga dan ikan}

Masyarakat di sekitar TN Kayan Mentarang memperoleh protein dari berbagai jenis binatang buruan. Jenis-jenis paling umum yang menjadi kesukaan masyarakat adalah ba'bui (Sus barbatus) (lihat Foto 1), uca' ano (Muntiacus muntjac), payau (Cerius unicolor), pelanuk (Tragulus javanicus), setung umung (Hystrix brachyura), dan banyak jenis binatang lainnya dapat dilihat dalam tabel terlampir. Jenis binatang yang dipanen dalam satu tahun rata-rata 9 sampai 14 jenis per rumah tangga per kampung, dan 100\% merupakan binatang liar.

Beberapa jenis serangga juga merupakan sumber protein. Sejenis larva kumbang palem dari ordo Coleoptera yang disebut su'et (Rhynchophorus ferrugineus) enak dimakan dan sangat digemari. Jenis lainnya berasal dari larva coleoptera yang hidup di kayu keras, misalnya ulet samban (Monochamus spp.) diambil dari kayu seleman (Weinmannia blumei). Selain itu, larva berbagai jenis lebah yang disebut tilo layuk (Apis dorsata) biasanya diambil di pohon kayu tanyit (Koompassia excelsa). Jenis belalang dari ordo Orthoptera yang disebut pau (Famili Acrididae) biasanya banyak ditemukan di rumputrumputan. Kurang lebih 4 sampai 11 jenis serangga dipanen per rumah tangga per desa di sekitar TN Kayan Mentarang dalam jangka waktu satu tahun. 
Sungai-sungai yang terdapat di dalam hutan kaya dengan berbagai jenis ikan dan jumlahnya sangat banyak. Jenis-jenis ikan yang paling sering ditemukan adalah pasa' (Lobocheilos faliifer), selareng (= patin: Pangasius niewenhuisi), salap (Barbodes balleroides), atuk buleng (=dungan: Hampala macrolepidota bimaculata), padek (Tor if. tambra), teliken (Mystus wyckii), kati (=lele: Chana sp.), betelo (Rasbora sp.), munjuk (=belevan: Osteochilus sp.), tekasang ka (Parbomaloptera sp.), telan (Mastacembelus armatus) dan lain-lain. Rata-rata ada 9 sampai 16 jenis ikan dipanen per keluarga per desa di sekitar TN Kayan Mentarang.

Foto 1. Babi hutan dan dagingnya di L. Tebulo

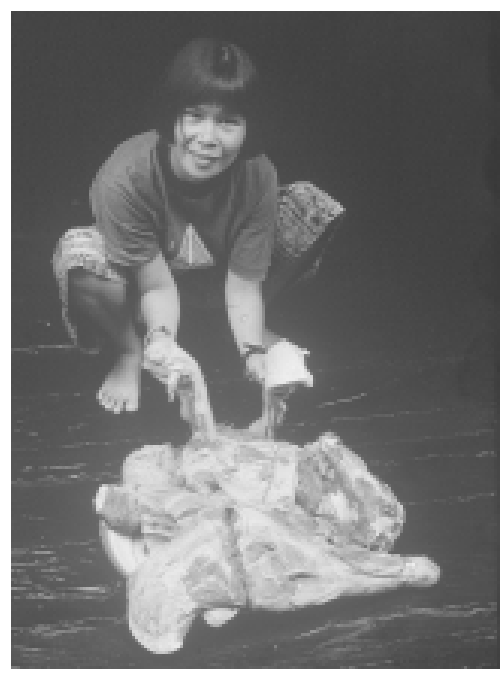

b. Di hutan diperoleh karbohidrat dari berbagai jenis palem dan umbi-umbian

Beberapa rumah tangga di sekitar TN Kayan Mentarang memperoleh karbohidrat dari palu atau sagu dari berbagai jenis palem, misalnya nanga (Eugeissona utilis), talang (Arenga undulatifolia), bo'e (Arenga brevipes), dan lain-lain. Ada satu sampai empat jenis sagu yang dipanen per rumah tangga per desa, sekitar 16\% sampai 19\% dipanen dari 
yang tumbuh liar di hutan, kecuali di Apau Ping 0\% (mungkin memanen sagu dari yang ditanam di kebun, atau kebetulan, tidak panen sagu tahun itu). Salah satu kelompok masyarakat yang sangat tergantung pada sagu adalah masyarakat Punan. Mereka tidak masuk dalam survei ini tetapi diketahui mereka sangat tergantung pada sagu sebagai makanan pokok kalau sedang jalan di hutan. Selain dari palem, karbohidrat juga dapat diperoleh dari berbagai jenis umbi-umbian yang tumbuh secara liar di dalam hutan. Sebagai contoh lundai (Xanthosoma sp., Colocasia gigantea), luan si'ik (Dioscorea pentaphylla), luan bala (Dioscorea alata), dan lain-lain.

Makanan ini sangat penting bagi orang yang sedang melakukan perjalanan di dalam hutan, sehingga apabila sewaktu-waktu mereka menginap di hutan tidak perlu membawa bekal yang banyak dari rumah. Apabila kehabisan beras, makanan inilah yang banyak dimanfaatkan. Selain itu makanan tersebut di atas juga penting untuk makanan selingan atau makanan tambahan apabila bosan dengan jenis makanan pokok.

Sumber karbohidrat dari hutan penting bagi orang Dayak sebagai cadangan bahan makanan untuk dimanfaatkan di musim paceklik, apabila ladang gagal panen di musim kemarau. Menurut pengalaman pada tahun 1997-98 di daerah Sungai Bahau masyarakat mengalami gagan panen karena adanya musim kemarau panjang oleh pengaruh El Niño. Ditambah lagi dengan adanya krisis moneter pada waktu itu, di mana persediaan beras habis dan harga membubung tinggi. Beras yang biasanya seharga Rp. 1.000 per kg, melonjak menjadi Rp. 9.000 per kg. Hal ini selain disebabkan kehabisan stok dalam negeri, beras impor yang harganya sekitar Rp. 2.500 per kg di Tarakan, harus diangkut dengan pesawat MAF (Missionary Aviation Fellowship) dengan ongkos Rp. 6.000 per kg, kemudian pengusaha mengutip keuntungan Rp. 500 per kg. Masyarakat yang umumnya ekonomi lemah tidak mampu menjangkau harga tersebut. Di sinilah terbukti bahwa hutan merupakan lumbung hidup bagi masyarakat Dayak, apabila ladangnya gagal, mereka masih memiliki banyak jenis sumber bahan makanan yang tumbuh secara liar di hutan. 


\section{c. Di hutan diperoleh vitamin dari sayur dan buah-buahan}

Di hutan terdapat berbagai jenis tumbuhan yang digunakan oleh masyarakat sebagai sayur. Beberapa jenis tumbuhan yang paling sering digunakan dalam kehidupan sehari-hari antara lain kelompok pakupakuan, misalnya: paku bala (Stenoclaena palustris), paku bai (Dipląium esculentum) (lihat Foto 2), paku pa'it (Athyrium sorongonense), paku julut (Nephrolepis bisserata), dan lain-lain. Berbagai jenis pucuk daun, ubut, dan rebung (lihat Foto 3) juga diambil sebagai sayuran. Ubut dari pisang hutan ada beberapa jenis seperti ubut utai (Musa sp1.), lebem (Musa sp2.), dan sawan (=punyang: Musa sp3). Ubut dari jenis palem dan ubut rotan hampir semua dapat dimakan, contohnya adalah ubut talang (Arenga undulatifolia), ubut nanga(Eugeissona utilis), ubut nyibung (Oncosperma horridum), ubut uwai tebungen (Calamus ornatus), ubut uwai balamata (Calamus sp1.), ubut uwai pa'it (Calamus sp2.). Ubut dari jenis jahe-jahean hutan dari famili Zingiberaceae banyak dimakan misalnya beberapa jenis nyanding (Etlingera elation), ucuk kuang (Nicolaia speciosa), ubut seriteng, ubut sua', ubut tepo', dan ubut tite'. Selain itu berbagai jenis jamur seperti: kulat long (Amanita sp.) (lihat Foto 4), kulat long belabau (Russula cyanoxantha), kulat tau (Craterellus cornucopides), kulat kedet

Foto 2. Paku bai (Apau Ping)

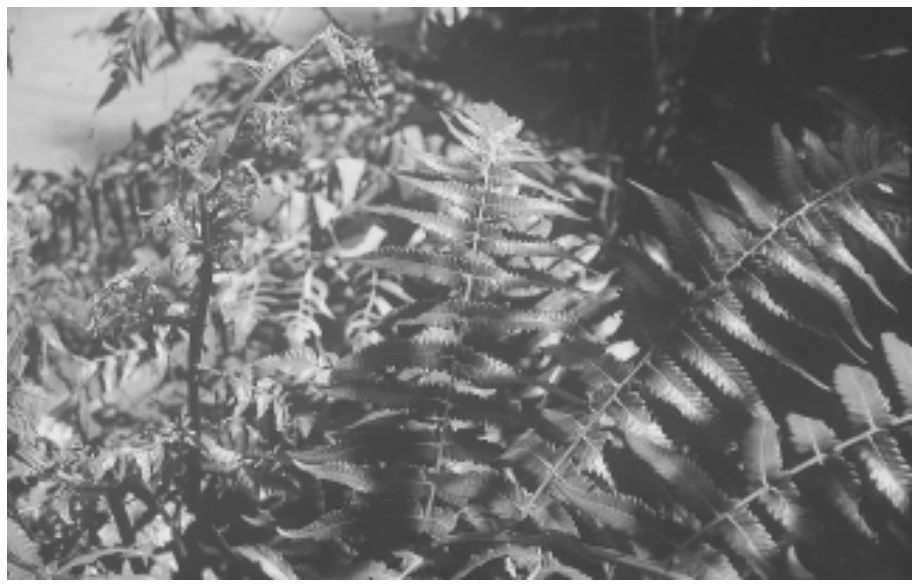


Foto 3. Persiapan ubud bambu di Apau Ping

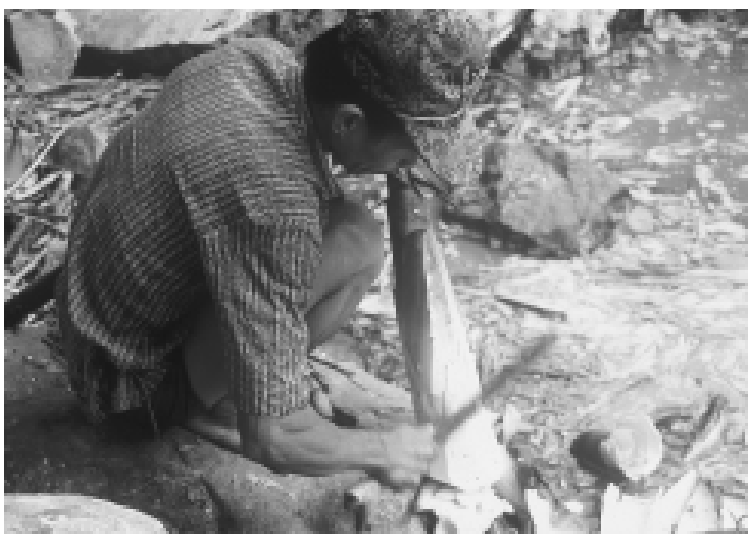

Foto 4. Kulat long

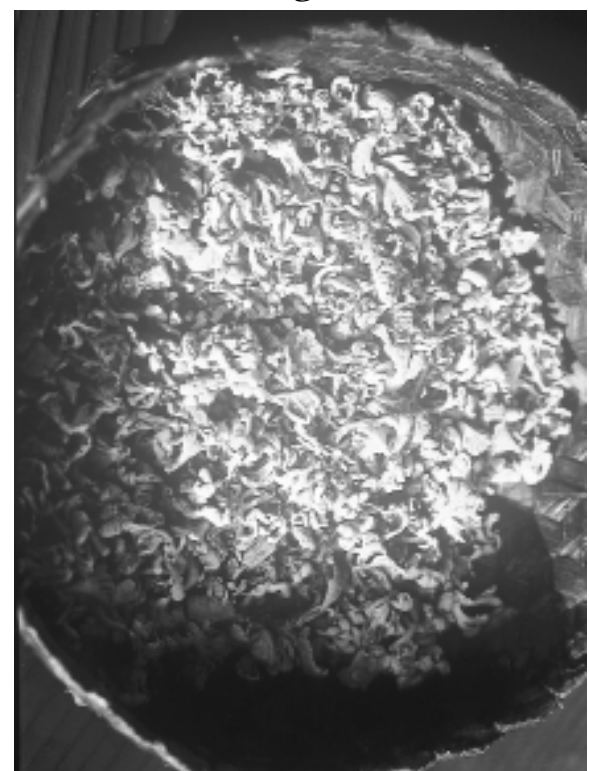


(belum diidentifikasi), kujep (Pleurotus sp.), kulat palan (Agaricus angustus), kulat ulek (Agaricus ariensis), kulat sulip (Hydnum repandum), kulat bulu (Lactarius deliciosus), dan lain-lain. Rata-rata ada 17 sampai 25 jenis sayuran yang dimanfaatkan per keluarga per kampung dalam satu tahun dan antara $72 \%$ sampai $85 \%$ dipanen dari yang tumbuh secara liar di hutan baik di hutan primer maupun hutan sekunder.

Buah-buahan sebagai sumber vitamin yang penting dan sangat digemari sebagai contoh adalah dian da'un (Durio oxleyanus), dian kalang (Durio zibethinus), isau bala (Dimocarpus longan ssp. malesianus var. malesianus), isau bileng (Dimocarpus longan ssp1.), bua' a'bung (Nephelium ramboutan-ake), bua' sanggit (Nephelium lappaceum), bua' unjing (Nephelium maingayi), berenyiu (Mangifera caesia), mangga (Mangifera indica), alim (Mangifera pajang), nakan (Artocarpus integer), kian (Artocarpus odoratissimus), basut (Artocarpus lanceifolius), bitung (Garcinia mangostana), langset (Lancium domesticum), settai (Baccaurea macrocarpa), kelepesso (Baccaurea lanceolata), konye (Baccaureapariiflora), keramo' (Dacryodes rostrata), mejalin (Xanthophyllum scortechinii), mejalin batu (Xanthophyllum exelsa), dan lain-lain. Berdasarkan hasil penelitian ini diketahui bahwa rata-rata ada 8 sampai 12 jenis buahbuahan yang dipanen per keluarga per kampung. Sekitar 17\% sampai $38 \%$ dipanen dari hutan liar. Selebihnya dipetik dari hasil yang ditanam di kebun.

\section{d. Di hutan diperoleh bumbu untuk masakan sehari-hari}

Sebagian bumbu yang dipakai dalam kehidupan sehari-hari berasal dari tumbuhan liar yang terdapat di hutan. Hasil penelitian ini menunjukkan rata-rata ada 6 sampai 10 jenis bumbu yang digunakan per keluarga. Bahan bumbu tersebut yang berasal dari hutan liar berkisar antara 70\% sampai 73\%. Tumbuhan dari hutan liar yang paling umum dijadikan bumbu adalah: bekkai lan (Pycnarhena cauliflora) (lihat Foto 5), bekkai lanya (Coscinium miosepalum), belengla (Litsea cubeba), uba tepuh (Eugenia sp.) sejenis daun salam, ulem (Solanum torum), dan lain-lain. Bahan bumbu yang lain diambil dari hasil yang ditanam di kebun. 
Foto 5. Bekkai yang siap untuk dipakai (L. Alango)

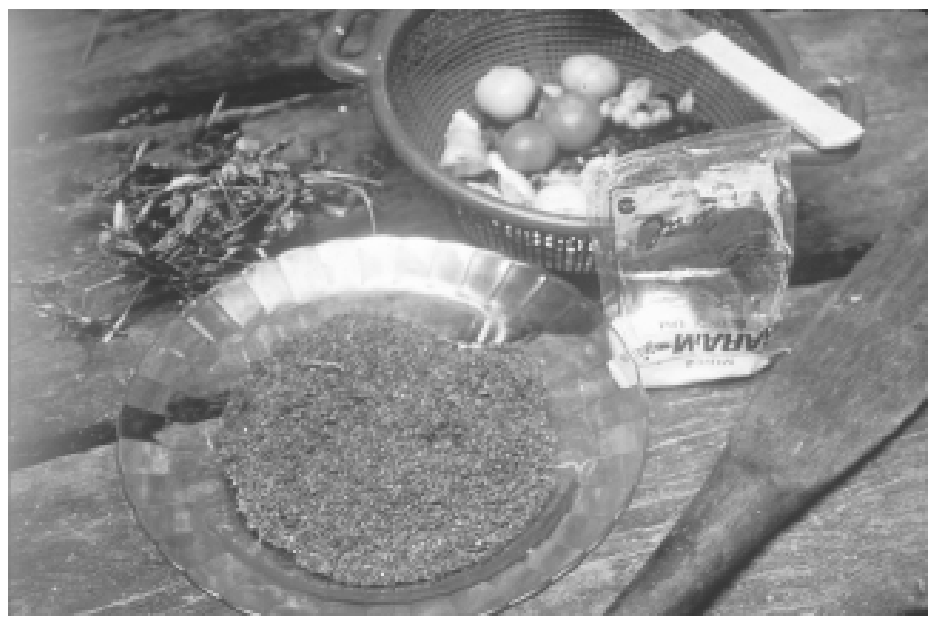

Selain yang telah disebutkan di atas, ada biji-bijian yang berasal dari tumbuhan liar di hutan dapat dimakan dan sangat disukai baik sebagai sayur, bumbu, atau dimakan langsung. Sebagai contoh adalah: beta (Parkia speciosa), payang kayu (Pangium edule), payang kure' (Aleurites moluccana), payang salap (Sumbariopsis albicans), payang aka (nama ilmiah tidak diketahui), bua' bangan (Castanopsis argentea), dan lain-lain. Pada umumnya orang-orang di kampung suka makan payang . Orang di kampung mengatakan, "jika ada payang, ikan terasa tawar", suatu ungkapan yang menyatakan bahwa payang sangat enak.

Kebutuhan keluarga untuk minyak makan dapat terpenuhi dari lemak babi hutan (ba'bui, Sus barbatus) yang digoreng sehingga mengeluarkan banyak minyak. Minyak inilah yang digunakan untuk kebutuhan memasak sehari-hari. Minyak babi tersebut adalah minyak khas yang disukai oleh orang Dayak, karena menurut mereka rasanya lebih enak kalau dibandingkan dengan minyak makan dari toko. Ada juga orang Dayak yang sudah pindah ke kota tapi mereka masih suka dengan minyak babi dari kampung. Kemungkinan untuk mendapatkan minyak dari babi hutan dapat mengurangi pengeluaran biaya, bahkan minyak tersebut dijual untuk menghasilkan uang tunai.

Pengamatan di Sungai Bahau membuktikan kebutuhan masyarakat Dayak terhadap minyak babi. Hasil buruan berupa babi 
lebih disukai daripada binatang yang lainnya. Jika seseorang pergi berburu dan mendapatkan beberapa ekor babi, maka yang lebih diutamakan dibawa pulang adalah lemak dan kulitnya. Apabila dagingnya tidak bisa dibawa pulang, maka ditinggalkan di dalam hutan. Mendapatkan babi gemuk dengan lemak yang tebal adalah kebanggaan. Di kampung biasanya orang-orang bertanya, "Berapa tebal lemaknya?". Babi yang gemuk umumnya mempunyai lemak setebal dua sampai empat jari.

\section{Hutan Sebagai Sumber Obat-obatan}

a. Di hutan diperoleh obat-obatan yang berasal dari tumbuhtumbuhan

Jenis tumbuhan obat yang paling umum dan sering dipakai antara lain: lembang pait (Eurycoma longifolia), lirang tana'(Euphorbia sp.), abung aa' (Ficus glomerata), a'bung bileng (Ficus hemsleyana), kayu pedek (=benua) (Macaranga triloba), paung lung (Xanthosoma sp.), kudip (Dillenia serata), aka lembo' (=aut bulu) (Passiflora sp.), aka pa'it (Fibraurea sp. dan Arcangelisia flava), sekau (Aquilaria sp.), simang, aka pejeling, kerenga mudung (Acorus calamus), dan lainlain. Hasil penelitian ini menunjukkan bahwa, setidaknya ada 4 sampai 12 jenis tumbuhan yang paling umum dipakai per keluarga per kampung untuk obat. Dari jenis-jenis tersebut 36\% sampai $43 \%$ berasal dari hutan liar. Soedjito 1991, mengemukakan bahwa telah diketahui tumbuhan obat-obatan sebanyak 150 jenis dari 132 genera dan 63 famili (hasil penelitian di daerah hulu Sungai Bahau).

\section{b. Di hutan diperoleh obat-obatan yang berasal dari binatang dan serangga}

Selain obat yang diperoleh dari tumbuhan, juga banyak obat-obatan yang diperoleh dari binatang. Sebagai contoh yang paling umum adalah: empedu buang (Helarctos malayanus), empedu kitan (Arctictis 
binturong), burung krukep (Centropus rectunguis), manuk ilang (Copsychus saularis), tanduk payau yang masih muda (Cerrus unicolor), janin pelanuk (Tragulus javanicus.), madu layuk (Apis dorsata), minyak dari ulet samban (Monochamus sp.) dan lain-lain. Empedu dari jenisjenis binatang ini jarang diambil, kadang-kadang dalam satu keluarga hanya memperolehnya satu kali dalam satu tahun. Penggunaan empedu sebagai obat dapat dilakukan dengan berbagai cara. Ada orang yang langsung memakannya, dan ada juga yang mencampur dengan minyak kelapa sebagai obat gosok untuk mengurut orang yang salah urat atau keseleo. Burung krukep digunakan untuk obat patah tulang. Sedangkan manuk ilang dipakai sebagai obat untuk anak-anak yang belum bisa berbicara atau gagap. Diyakini bahwa kalau anak tersebut diberi makan daging burung ini, maka bisa berbicara lancar, karena burung ini banyak bicara. Tanduk payau yang masih muda dan janin pelanuk biasanya direndam di dalam $\boldsymbol{a r a k}^{6}$ sebagai obat.

Sebagian orang mengambil bagian binatang bukan untuk obat, tetapi lebih suka menjual bagian dari binatang ini ke Malaysia karena harganya mahal di sana. Bagian binatang yang sering dijual adalah batu bangat (Presbytis hosei) dan batu settong umung (Hystrix brachyura). Orang Dayak di daerah Sungai Bahau pada umumnya tidak menggunakannya sebagai obat.

\section{Hutan Sebagai Sumber Bahan Bangunan dan Perahu}

Kayu-kayu di daerah Sungai Bahau yang dapat dimanfaatkan sebagai bahan bangunan dan perahu sangat banyak jenisnya. Masyarakat mempunyai banyak pilihan untuk memanfaatkan jenis-jenis yang disukai. Umumnya mereka memanfaatkan jenis-jenis kayu yang berkualitas baik sebagai pilihan utama, kemudian pilihan kedua untuk jenis kayu lainnya. Hasil penelitian ini menunjukkan bahwa ada 10 sampai 13 jenis kayu yang dimanfaatkan rata-rata per keluarga per kampung, dalam tahun 1995-96. Jenis-jenis tersebut 94\% sampai 95\% dipanen dari yang tumbuh liar di hutan. 


\section{a. Kayu-kayu yang penting untuk bahan bangunan rumah}

Masyarakat memilih beberapa jenis kayu yang memiliki kualitas baik sebagai bahan bangunan rumah dari segi kekuatan, tahan lama, serat halus, dan sebagainya. Berdasarkan penggunaannya, kayu-kayu tersebut dapat dikelompokkan sebagai berikut:

(1) Untuk tiang rumah antara lain; kayu belien (=ulin: Eusideroxylon zwageri), lemelai (Pternandra sp.), kayu merang (Diospyros sp.) dan lain-lain. Kayu-kayu ini kuat, tahan air, tidak diserang serangga, dan tahan lama karena tidak mudah lapuk. Kayu ulin dapat bertahan sampai ratusan tahun.

(2). Untuk gelagar, kaso, dan reng biasa digunakan kayu kapun (Dryobalanops lanceolata), penjae (=laran ba'bui: Hopea mengerawan), pilong (Ochanostachys amentacea), pung ubi (Santivia tomentosa), dan lain-lain. Kayu-kayu ini umumnya kuat, berserat lurus sehingga mudah dikerjakan apabila digergaji dan diketam.

(3). Untuk dinding biasanya dipakai kayu penjae (Hopea mengerawan) dan adau (Elmerrillia mollis)(lihat Foto 6). Kayu ini berserat halus, mudah diketam untuk dibuat halus permukaannya karena seratnya lurus.

(4). Untuk atap dibuat sirap dari kayu nyeliwai (Quercus argentea) dan kayu belien (Eusideroxylon zwageri), dan kayu benato (Shorea argentifolia Sym.). Kayu nyeliwai paling banyak digunakan di hulu Sungai Bahau. Kayu ini berserat lurus yang menyebabkan mudah dibelah menjadi ukuran kecil yang tipis, dan kayu ini tetap kuat karena adanya serat melintang yang besar (sel jari-jari kayu).

\section{b. Kayu-kayu yang penting untuk perahu}

Sarana transportasi di daerah Sungai Bahau adalah perahu. Perahu dipakai sehari-hari untuk pergi ke ladang, ke kampung tetangga, dan 
Foto 6. Kayu adau dijemur di hutan sebagai persiapan sebelum bangun rumah di Apau Ping

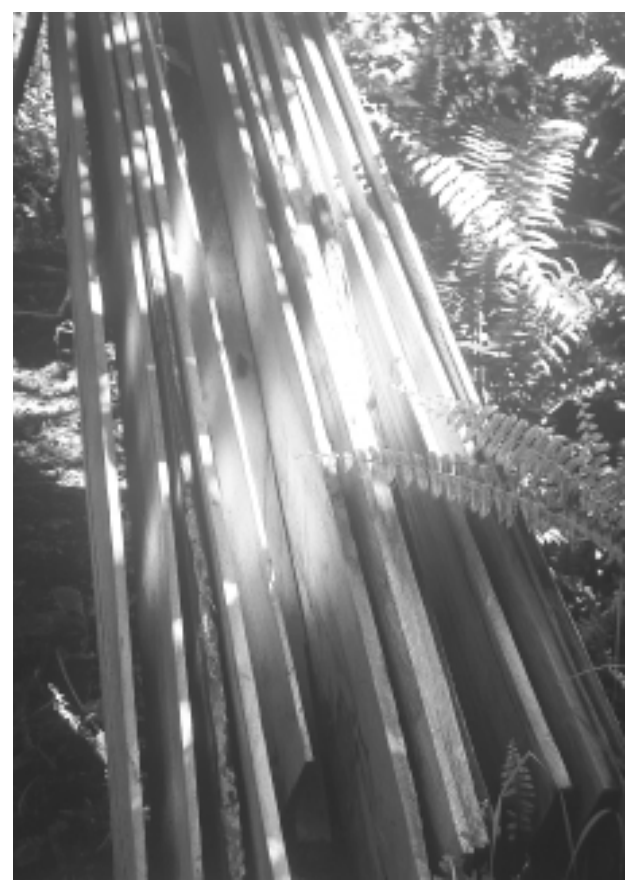

bepergian jauh misalnya ke kota. Di Sungai Bahau walaupun banyak jeram yang sangat berbahaya tetapi masyarakat di sana sudah biasa mondar-mandir melewati arus sungai yang deras. Perahu buatan sendiri biasa digunakan terjun di jeram kemudian ditarik ke atas batu. Masyarakat sudah mahir dengan dinamika air ketika banjir maupun dalam keadaan surut.

Kayu-kayu yang digunakan untuk membuat perahu juga merupakan kayu terpilih. Ada beberapa jenis kayu yang paling umum dipakai dapat dikelompokkan sebagai berikut:

(1). Untuk lunas atau batang alut (alas perahu) biasa digunakan kayu saleng (Diospyros borneensis), tebulo (Eugenia sp.), dan penjae (Hopea mengerawan). Karena kayu ini kuat dan licin, tidak lengket jika kandas di batu. 
(2). Untuk kapi (dinding perahu) biasa digunakan kayu adau (Elmerrillia mollis) dan penjae (Hopea mengerawan) karena kayu ini ringan, seratnya bagus, dan tahan air.

(3). Untuk dayung biasa digunakan kayu nyeliwai bala (Quercus argentea), nyeliwai bileng (Quercus gmelliflora). Kayu ini seratnya lurus, mudah dibikin pipih, dan kuat karena ada serat yang melintang (sel jari-jari kayu).

(4). Untuk tanggar (semacam tongkat untuk mendorong jika kandas atau melewati jeram), kayu yang biasa digunakan adalah tema (Memecylon garcindes), tema bala (Memecylon costatum), dan lain-lain. Kayu ini dipilih karena umumnya lurus, panjang, kuat, bulat, dan tahan air.

(5). Untuk menambal perahu apabila terjadi kebocoran, terutama pada sambungan bagian-bagian papannya, digunakan tu'dan (damar) yang berasal dari pohon-pohon yang tumbuh secara liar di hutan (lihat bagian damar di bawah ini). Damar ini ditumbuk lalu dipanaskan sampai cair disebut lisan. Damar cenderung lebih disukai karena damar tidak ditembus oleh air.

\section{Hutan sebagai Sumber Pendapatan Uang Tunai}

\section{a. Pendapatan dari kayu gaharu (Aquilaria spp.) dan kayu manis (Cinnamomum burmanni)}

Gaharu adalah zat ekstraktif berupa resin yang diproduksi oleh jenis kayu tertentu yang berfungsi untuk menangkal serangan hama dan penyakit yang berasal dari luar. Zat ekstraktif ini bersifat racun, sehingga agen perusak kayu (seperti: serangga, bakteri, dan jamur) tidak bisa masuk ke dalam kayu. Di bagian kayu gubal sering terbentuk endapan zat ekstraktif ini, karena bagian kayu tersebut luka ${ }^{7}$ yang disebabkan oleh ranting patah, diserang binatang, atau faktor perusak yang lain. Secara alami zat ekstraktif ini mengendap di bagian dalam kayu teras yang menyebabkan warna kayu menjadi gelap kehitaman. Gaharu (lihat Foto 7) berbau harum yang menyebabkan harganya 
mahal. Gaharu digunakan sebagai dupa dengan harum khas, dipasarkan ke Saudi Arabia, Hong Kong, Singapura, dan tempat lain dengan harga tinggi. Untuk informasi lebih mendalam mengenai keadaan gaharu di hulu Sungai Bahau, lihat Momberg et al. (2000) dan Wollenberg (2001).

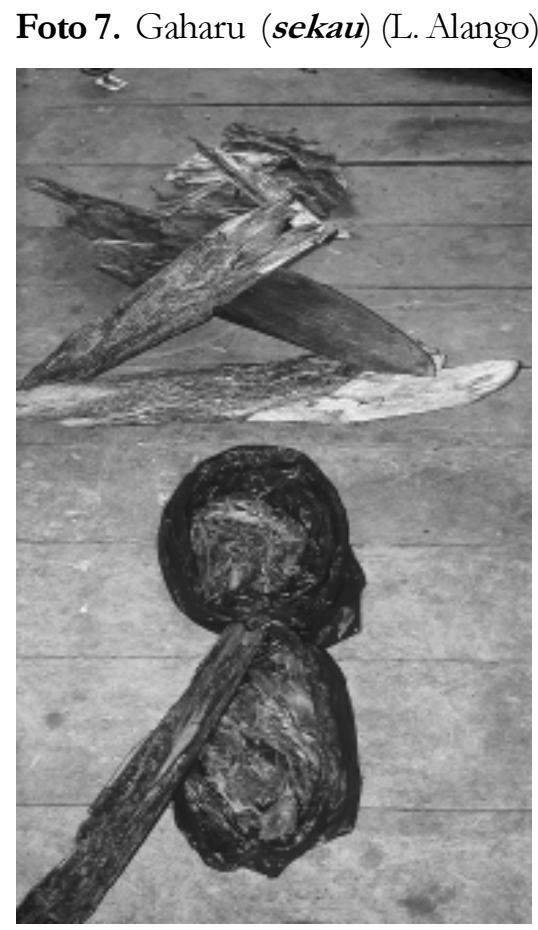

Di daerah Sungai Bahau masyarakat mengenal lima jenis gaharu yang disebut sekau antara lain: sekau mu'dung (Aquilaria malaccensis), sekau buaya (Aquilaria beccariana), sekau nyibung, sekau bai, dan sekau cabut. Gaharu merupakan sumber pendapatan utama untuk memperoleh uang tunai. Berdasarkan hasil penelitian ini ratarata $40 \%$ sampai $81 \%$ rumah tangga per kampung mendapatkan uang tunai dari hasil gaharu. Rumah tangga yang mengandalkan sumber pendapatan dari kayu gaharu tersebut rata-rata memperoleh uang tunai sekitar 56\% sampai $69 \%$ dari rata-rata jumlah pendapatan total. 
Jika dibandingkan dengan sumber pendapatan dari hasil hutan lainnya (misalnya: rotan, kayu manis, ketipai, buah-buahan, dan lainlain), pendapatan dari gaharu mencapai 92\% sampai 100\%. Ini menunjukkan bahwa pendapatan dari hasil kayu gaharu menduduki tempat teratas dibandingkan dengan sumber pendapatan uang tunai lainnya, baik yang berasal dari hutan primer maupun dari hutan sekunder.

Pada saat ini gaharu super dijual seharga 7 juta rupiah per kg. Harga gaharu cenderung terus meningkat sejak tahun 1990 sampai 1999. Namun sebagian masyarakat meramalkan bahwa harga gaharu di suatu saat akan jatuh, sedangkan harga hasil hutan lainnya meningkat.

Selain gaharu, sumber pendapatan yang penting lainnya adalah kayu manis (kayu me: Cinnamomum burmanni) (lihat Foto 8). Harga kayu manis relatif stabil yaitu sekitar 1 - 1,5 ribu rupiah per $\mathrm{kg}$ kalau dijual di kampung. Hasil penelitian ini menunjukkan bahwa pendapatan uang tunai dari hasil penjualan kayu manis hanya terdapat

Foto 8. Kayu manis (kayu me) di L. Alango

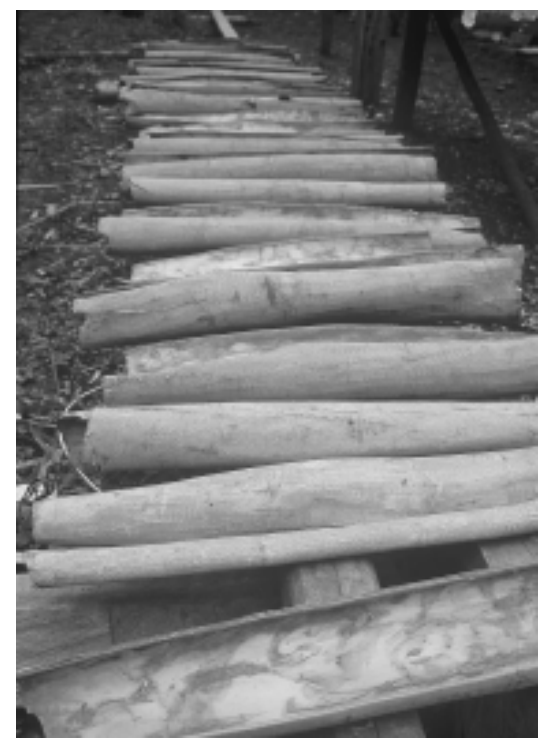


di Apau Ping dan Long Alango, yaitu sekitar satu sampai tujuh keluarga atau sekitar 3\% sampai $22 \%$ dari penduduk per desa. Dibandingkan dengan pendapatan uang tunai dari penjualan hasil hutan lainnya, hasil penjualan kayu manis mencapai 4\%.

\section{b. Pendapatan dari penjualan hasil hutan selain gaharu dan kayu manis}

Selain gaharu dan kayu manis masih ada berbagai hasil hutan yang bisa jadi sumber pendapatan. Hasil hutan dimaksud merupakan pilihan yang dapat saling menggantikan di saat harga salah satu jenis mengalami fluktuasi. Hasil penelitian ini menunjukkan rata-rata 6 sampai 22 rumah tangga, atau sekitar 19\% sampai 55\% rumah tangga per desa mendapatkan uang tunai dari penjualan hasil hutan selain gaharu dan kayu manis.

Pasar hasil hutan selalu berubah pada setiap beberapa tahun. Sejak tahun 1973-85 harga rotan mentah Rp. 125 per kg, kemudian pada tahun 1986-89 naik menjadi Rp. 500 per kg. Mulai tahun 1989 harga rotan menurun sampai jatuh tidak ada harga. Pada tahun 199196 masyarakat tidak ada lagi yang menjual rotan mentah, sebab tidak ada pembeli ${ }^{8}$. Pada tahun 1997-98 harga rotan mulai membaik sekitar 2 - 4 ribu per kg.

Penjualan kayu-kayu bangunan sudah tidak ada sampai sekarang. Pada tahun 1969-73 dan 1989 penjualan kayu-kayu bangunan sangat ramai akibat banjir-kap. Banjir-kap itu adalah istilah yang dipakai di Malinau yang bermaksud penebangan liar. Kayu yang dekat pinggir sungai ditebang secara tidak resmi dan dibawa ke pembelinya lewat sungai. Sekarang masyarakat menjual kayu dalam bentuk barang jadi, misalnya perahu sangat laku dijual walaupun dengan harga tinggi. Demikian juga halnya dengan damar, sudah tidak laku lagi, masyarakat memungut damar untuk kebutuhan sendiri. Getah ketipai (Palaquium quercifolium) masih memiliki harga, tetapi hanya untuk memenuhi pasaran lokal saja, misalnya antar keluarga dalam satu kampung dengan harga jual Rp. 4-5 ribu per batang berdiameter $2 \mathrm{~cm}$ dengan panjang $5 \mathrm{~cm}$. 
Penjualan hasil hutan berupa buah-buahan cenderung meningkat pada tahun-tahun belakangan ini. Harga buah mata kucing (isau bala: Dimocarpus longan ssp. malesianus var. malesianus) meningkat dari Rp. 5.000 per kaleng ( $1 \mathrm{kaleng}=12-13 \mathrm{~kg}$ ) pada tahun 1986 menjadi Rp. 7.000 per kaleng tahun 1987 (lihat juga Puri 1998). Pada tahun 1998 meningkat tajam mencapai Rp. 18.000 per kaleng. Jadi selama tiga tahun ini harga buah mata kucing rata-rata meningkat 98,5\% per tahun. Keadaan ini sangat dipengaruhi oleh keadaan perekonomian dalam negeri terutama gejolak moneter, pangsa pasar, dan kelancaran transportasi dari hulu ke hilir. Buah-buahan yang lain juga mengikuti perkembangan harga yang baik, seperti: dian da'un (Durio oxleyanus), dian kalang (Durio zibethinus), bua' a'bung (Nephelium ramboutan-ake), bua' sanggit (Nephelium lappaceum), bua' unjing (Nephelium maingayi), berenyiu (Mangifera caesia), mangga (Mangifera indica), alim (Mangifera pajang), nakan (Artocarpus integer), kian (Artocarpus odoratissimus), basut (Artocarpus lanceifolius), bitung (Garinia mangostana), dan langset (Lansium domesticum).

Telah disebutkan di atas bahwa buah-buahan ini masih banyak dipanen dari hutan liar, yaitu sekitar 17\% sampai 38\%. Masyarakat akan tetap dapat memanen hasil secara berlanjut hanya kalau hutan masih bagus. Pemanenan buah-buahan ini tanpa menimbulkan kerusakan terhadap hutan. Cara memanen yang baik memungkinkan untuk bisa menjual hasilnya setiap tahun. Ini sangat berbeda jika dibandingkan dengan penjualan dari penebangan kayu, yang dampaknya sangat merusak apabila dilakukan dalam sekala luas.

\section{c. Penjualan hasil hutan berupa barang-barang hasil olahan}

Barang-barang hasil olahan dijual untuk menghasilkan uang tunai. Jenis-jenis barang olahan yang umum dijual adalah tikar, topi, dan tas rotan (dalam penelitian ini hasil penjualan barang olahan digabung dengan penjualan arak). Hasil penelitian ini menunjukkan rata-rata 16 sampai 18 rumah tangga, atau berkisar antara 38\% sampai 52\% rumah tangga per kampung mendapatkan penghasilan uang tunai dari penjualan barang-barang olahan pada tahun 1995-96. Pada 
perkembangan belakangan ini semakin banyak barang-barang olahan yang dapat dijual, antara lain: sumpit, sambe', ki'ba, ingen, tapan, dan lain-lain. Barang-barang ini sumber bahan bakunya berasal dari tumbuhan yang tumbuh liar di hutan.

Penjualan hasil hutan berupa barang-barang olahan dalam bentuk kerajinan dapat meningkatkan nilai tambah jika dibandingkan dengan penjualan langsung dalam keadaan mentah. Selain masyarakat mendapat hasil penjualan yang lebih tinggi, persediaan bahan baku juga dapat dihemat. Apabila menjual rotan mentah secara langsung, harganya murah dan perlu banyak rotan yang dijual. Sehingga sangat cepat menghabiskan persediaan sumber bahan baku di hutan. Sebagai contoh, satu belanyat (semacam tas dari rotan) ukuran sedang dibuat dari 45 - 50 batang ${ }^{9}$ rotan sega (Calamus caesius) dengan panjang 4 $5 \mathrm{~m}$ atau kurang lebih 1 gelung yaitu sekitar $4 \mathrm{~kg}$. Belanyat ini bisa dijual seharga 30 - 40 ribu rupiah pada tahun 1998. Sedangkan $1 \mathrm{~kg}$ rotan sega dijual kepada pedagang sekitar 2 - 4 ribu rupiah per kg. Orang yang membuat belanyat mendapat keuntungan senilai 14 32 ribu rupiah per belanyat atau sekitar 3,5 - 8 ribu rupiah per $\mathrm{kg}$ rotan sega. Besarnya keuntungan tergantung keahlian orang yang membuat belanyat tersebut, orang yang sudah mahir menganyam rotan mampu membuat belanyat yang berasal dari rotan yang berkualitas rendah (harga murah) menjadi sebuah belanyat yang bagus dengan harga mahal.

\section{Hutan sebagai Sumber Bahan Baku untuk Perlengkapan Kebutuhan Sehari-hari}

Orang Dayak dalam kehidupan sehari-hari banyak membutuhkan perlengkapan hidup, antara lain untuk memasak dan mengolah makanan, untuk membantu dalam mencari nafkah, untuk meringankan beban kerja, dan melindungi diri dari alam. Dalam tulisan ini yang dikelompokkan dalam perlengkapan kebutuhan sehari-hari meliputi: kayu bakar, getah parang, damar, sumpit, ki'ba, topi, tikar, tali, daun pembungkus, dan daun untuk atap. Barang-barang ini dibuat dari bahan-bahan yang diperoleh dari hutan. 
Foto 9. Mengumpulkan kayu api di Apau Ping

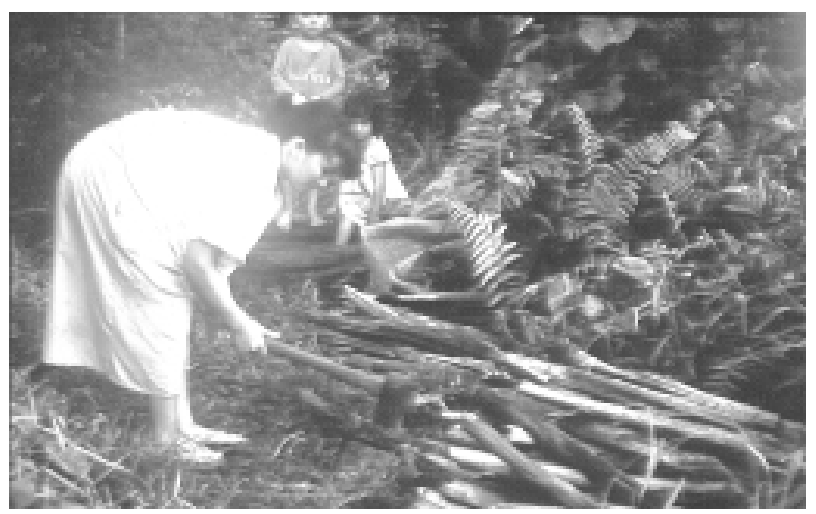

\section{a. Hutan merupakan sumber untuk memperoleh kayu bakar}

Pada umumnya orang Dayak di sekitar TN Kayan Mentarang menggunakan kayu bakar untuk keperluan memasak sehari-hari (lihat Foto 9a dan 9b). Hampir semua jenis kayu dapat digunakan sebagai kayu bakar. Kayu-kayu ini dapat diperoleh dengan mudah di hutan, baik di hutan rimba maupun di hutan-hutan sekunder muda bekas perladangan. Hasil penelitian ini menunjukkan bahwa ada beberapa jenis kayu tertentu yang paling disukai dan paling banyak dipakai sebagai kayu api di daerah Sungai Bahau. Jenis kayu api yang paling disukai antara lain: kayu japa'(Vitex pinnata), bine (Macaranga sp.), bela'ban (Tristaniopsis whiteana), palan (Lithocarpus spp.) dan lain-lain. Alasan dipilihnya kayu-kayu ini karena bagus dimakan api (mudah terbakar), mudah kering, dan tidak jauh dari rumah. Kebanyakan jenis kayu yang disukai oleh orang setempat untuk kayu api ada di jekkau (hutan sekunder bekas ladang).

Kayu yang bagus dimakan api adalah kayu keras (umumnya berat). Kayu yang disebutkan di atas adalah kayu keras kecuali kayu bine yang agak lemah. Kayu tersebut dipakai karena mudah didapat di hutan-hutan sekunder bekas ladang. Batang kayu yang masih kecil mudah dipotong memakai kapak sehingga tidak perlu tenaga banyak. Kayu ini pada umumnya mudah diangkut karena ladang dekat dengan rumah. Kayu-kayu besar walaupun lebih dekat, misalnya penjae 
(=laran ba'bui: Hopea mengerawan) tidak digunakan sebagai kayu api. Kayu yang besar sulit ditebang dan dipotong karena harus menggunakan gergaji rantai (chainsaw) dan lebih sulit untuk dibelahbelah karena besar.

Pada saat orang perlu menginap di hutan karena keperluan mencari hasil hutan atau berpergian jauh, mereka harus memasak di dalam hutan. Kayu api yang paling disukai di dalam hutan adalah kayu palan (Lithocarpus spp.), karena kayu ini mudah ditebang, mudah dibelah karena seratnya lurus, mudah kering karena pori kayu ini besarbesar, dan mengandung resin yang mudah dimakan api. Dalam keadaan segar (mentah), apabila kayu ini diraut halus bisa menyala oleh api kecil. Sedangkan potongan kayu palan lainnya yang sudah dibelah sebesar tiga jari, dapat kering dalam tempo setengah jam dan mudah menyala.

Orang Dayak selain membutuhkan kayu bakar untuk memasak, mereka juga perlu kayu bakar untuk menghangatkan badan yang disebut mendu (berdiang), terutama untuk anak kecil, pada musim hujan, dan apabila berada di dalam hutan. Jika berada di rumah mereka sering membakar kayu di bawah kolong untuk mengusir nyamuk dan untuk berdiang bagi anjing peliharaan. Kayu bakar juga dipakai untuk memasak makanan anjing, yaitu ubi yang biasanya harus direbus lama.

\section{b. Di hutan diperoleh getah parang ketipai (Palaquium quercifolium) untuk kebutuhan sehari-hari}

Semua orang Dayak di sekitar TN Kayan Mentarang membutuhkan parang untuk kehidupan sehari-hari, baik orang perempuan maupun laki-laki. Getah ketipai (Palaquium quercifolium) digunakan untuk merekatkan parang dengan tangkainya. Parang digunakan sebagai perlengkapan hidup untuk mencari nafkah dan perlindungan diri. Setiap pergi masuk hutan atau ke ladang mereka pasti membawa parang. Parang juga sangat berguna di dapur untuk membersihkan ikan, memotong daging dan kayu api. 
Getah ketipai diperoleh dari tumbuhan yang tumbuh liar di hutan. Selain getah ketipai ada sejenis getah lainnya yang berasal dari getah liana yang disebut aka plutan (Willughbeia sp.), yang bisa dipakai untuk getah parang. Getah plutan ini dipakai apabila ketipai sulit ditemukan. Jadi keduanya bisa saling menggantikan.

\section{c. Di hutan diperoleh tumbuh-tumbuhan untuk membuat sumpit}

Sumpit merupakan alat untuk berburu khas bagi orang Dayak. Sumpit terdiri dari beberapa bagian yaitu: (1) Buluh sumpit terbuat dari kayu yang dilubangi di bagian dalamnya. Kayu yang paling disukai untuk membuat sumpit adalah kayu bitung (Garinia mangostana), belien (=ulin: Eusideroxylon wwageri), dan kayu balet (Dipterocarpaceae). (2) Langan (anak sumpit sebesar lidi) terbuat dari kulit pelepah daun talang (Arenga undulatifolia). Langan ada dua macam yaitu langan lat dan langan bela'dang. Langan lat adalah anak sumpit biasa tanpa besi atau logam. Sedangkan langan bela'dang di ujungnya ada besi atau logam berbentuk segitiga. (3) Piping (pendorong) anak panah bagian belakang terbuat dari bagian dalam pelepah daun nanga (Eugeissona utilis) yang mirip seperti gabus, ringan didorong oleh tenaga angin. (4) Salo atau ipo'adalah racun sumpit yang dioleskan di ujung anak sumpit tersebut. Salo atau ipo' merupakan racun yang sangat kuat untuk binatang maupun bagi manusia. Racun ini berupa getah yang diambil dari pohon salo (=kayu ipo': Antiaris toxicaria) yang berasal dari tumbuhan liar di hutan. Selain racun yang berasal dari tumbuhan ada juga yang menggunakan racun yang berasal dari bisa ular yaitu sejenis ular cobra yang sangat berbisa, antara lain njau liban (= cobra coklat. Ophiophagus hannah) dan buah (= cobra hitam. Naja sumatrana).

Penggunaan sumpit dan racun untuk berburu binatang nampaknya ada kecenderungan mulai berkurang untuk generasi sekarang. Kebanyakan orang muda sekarang lebih senang menggunakan senapan buatan sendiri, karena lebih mudah memperoleh binatang. Ada juga beberapa keluarga yang masih mempertahankan cara berburu dengan menggunakan anjing dan 
bujak (lihat Foto 10), terutama kampung-kampung yang terletak di hulu, karena harga peluru sekarang sangat mahal. Peluru sulit didapat dari Malaysia karena petugas lebih tegas. Ada kemungkinan di masa yang akan datang berburu dengan anjing, sumpit, dan bujak akan meningkat sebab mahalnya peluru.

Foto 10. Orang yang siap berburu dengan bujak sambil pergi ke ladang (Apau Ping)

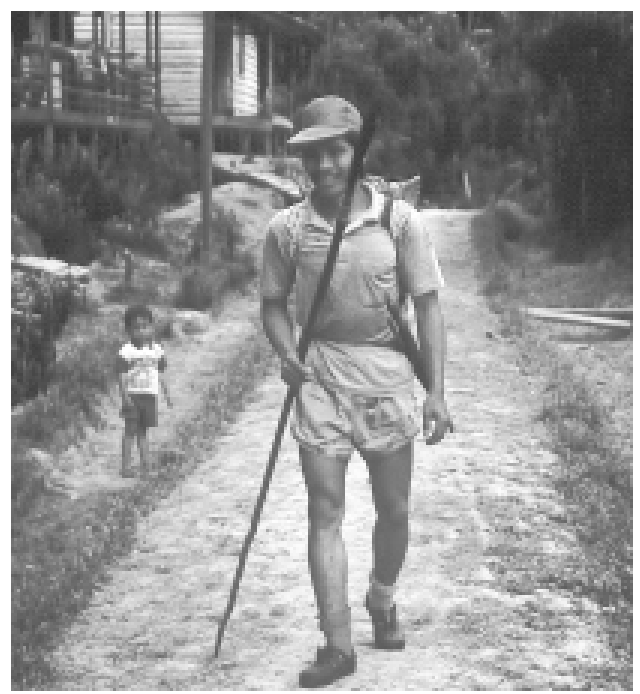

\section{d. Di hutan diperoleh bambu dan rotan untuk membuat alat- alat perlengkapan kerja}

Bambu dan rotan banyak dimanfaatkan untuk membuat alat-alat perlengkapan kerja seperti alat untuk menggendong barang seharihari, alat menggendong padi, menangkap ikan, membersihkan beras, tikar untuk alas tidur, alas menjemur padi, serta barang-barang kerajinan misalnya topi untuk perhiasan dan kebudayaan. Jenis-jenis bambu yang paling banyak digunakan adalah bulo lung (Dendrocalamus asper), bulo latung (Schizostachyum brachycladum), bulo lan (Schizostachyum latifolium), bulo panyut bileng (Bambusa inlgaris), bulo panyut bila' (Bambusa vulgaris cl. vittata) dan bulo pusa 
(Schizostachyum sp.). Jenis-jenis rotan adalah uwai seka (Calamus caesius) (lihat Foto 11), uwai tebungen (Calamus ornatus), uwai balamata (Calamus sp1.), uwai seringan (Daemonorops hallierianus), uwai semule' (Daemonorops periacanthus). Jumlah jenis bambu dan rotan yang dipanen per rumah tangga per desa ada 6 sampai 9 jenis. Dari jenis-jenis tersebut 95\% sampai 99\% dipanen dari hutan liar.

Orang Dayak lebih suka menggendong barangnya pada saat membawa dalam perjalanan, baik pada waktu mengangkut barang dari ladang maupun dari hutan atau sewaktu bepergian. Alat-alat yang biasa digunakan untuk menggendong barang adalah: ki'ba, ingen, belanyat beta, dan belanyat kalung. Ki'ba adalah semacam tas ransel terbuat dari rotan, berlobang besar-besar seperti keranjang berbentuk segi empat dan sangat elastis. Ingen adalah alat khusus untuk menggendong padi yang bentuknya juga segi empat terbuat dari bambu dianyam rapat tidak ada lobang. Ingen kurang elastis dibanding ki'ba. Belanyat beta adalah tas seperti keranjang kecil

Foto 11. Pengumpulan uwai seka (rotan sega) di hutan (Apau Ping)

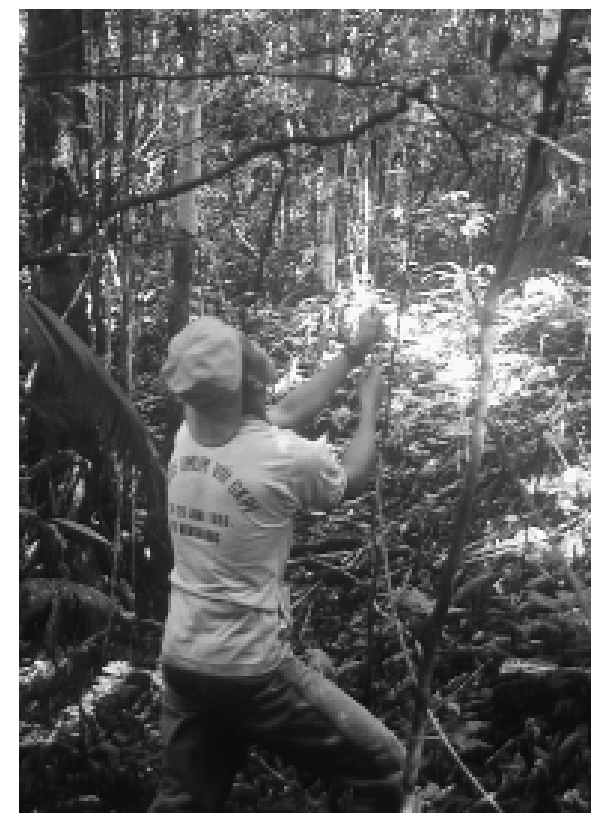


dengan banyak lubang. Belanyat beta umumnya dipakai untuk membawa ikan pada saat menjala, dan juga sering dipakai untuk membawa bekal ketika masuk hutan atau ke ladang. Pada jaman dulu belanyat beta dipakai khusus untuk upacara yang disebut melaki. ${ }^{10}$ Sedangkan belanyat kalung adalah tas indah yang bentuknya bulat ukurannya bervariasi dari kecil sampai besar (lihat Foto 12). Anyaman belanyat kalung ini memiliki corak ukiran khas Dayak dengan berbagai motif tertentu. Belanyat kalung hanya dibuat dari rotan yaitu uwai seka, sedangkan ki'ba dan belanyat beta dapat dibuat dari jenis rotan lain. Dalam kehidupan sehari-hari ki'ba dan belanyat beta lebih banyak digunakan untuk menggendong barang dan fungsinya lebih serbaguna, ingen umumnya hanya untuk menggendong padi. Sedangkan belanyat kalung hanya dipakai untuk bepergian ke tempat-tempat umum, tempat keramaian, atau ke pesta. Belanyat kalung sering diperjualbelikan secara lokal dan bahkan sampai ke luar pulau. Ada juga yang menggunakan belanyat kalung sebagai cenderamata.

Foto 12. Tiga contoh belanyat dari hulu Bahau

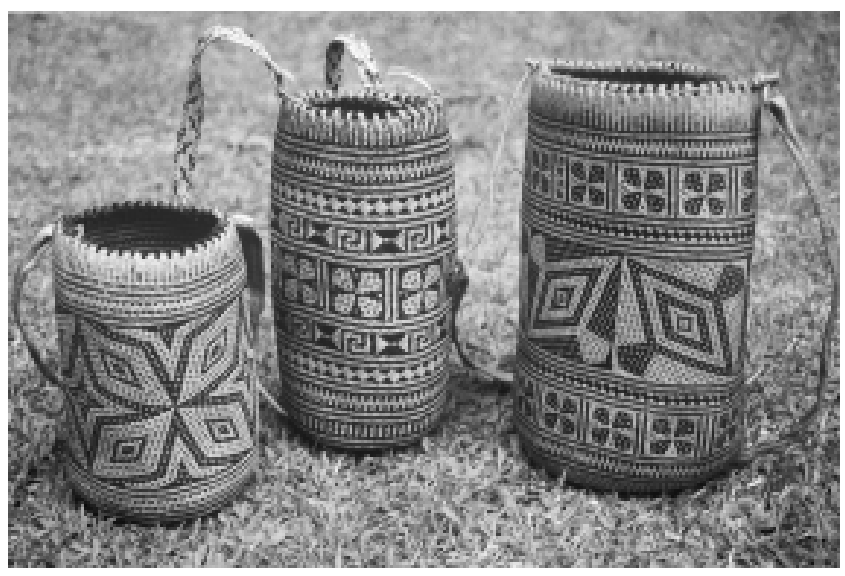

Alat lain yang dibuat dari bambu atau rotan adalah bubu, bading, kebang, tapan, terayung, taing, pat, saung seling, dan kerajinan lainnya. Bubu dan bading adalah alat untuk menangkap 
ikan di sungai berupa perangkap yang bentuknya bulat seperti botol tetapi ukurannya besar dengan panjang $1 \mathrm{~m}$. Kebangadalah alat untuk menumbuk bumbu dan sambal yang bentuknya seperti lesung, dibuat dari seruas bambu yang dipotong ujungnya dan dibiarkan satu bukunya. Bambu yang dipakai adalah bulo lung karena ruasnya kuat. Pasangannya adalah tun (=alu) yaitu alat untuk menumbuknya. Tapan adalah alat untuk membersihkan beras dari kotoran berupa sekam padi yang masih tersisa, atau biji padi yang belum terkupas, dan kotoran lain yang terikut. Beras diletakkan di atas tapan kemudian digoyang dan digetar-getarkan atau diayun-ayunkan sehingga kotorannya keluar. Terayung adalah anyaman dari bambu yang bentuknya lebar, ukurannya 0,5 x $1 \mathrm{~m}$ dipakai untuk alas barang di dalam ki'ba supaya barang-barang yang ukurannya kecil tidak jatuh. Terayung dibuat dari bulo pusa. Taing adalah tikar yang ukurannya relatif besar umumnya $5 \times 10$ m anyamannya agak kasar dipakai untuk alas menjemur padi atau sebagai karpet lantai di dalam rumah. Taing dibuat dari uwai semule'atau uwai seringan. Pat adalah tikar untuk alas tidur yang sangat halus dengan motif hitam puth yang indah. Gambar di dalamnya menunjukkan corak khas Dayak. Pat dibuat hanya dari uwai seka. Saung seling adalah topi yang berukuran lebar terbuat dari bambu juga dengan corak yang khas berisi lukisan tertentu lambang bangsawan (lihat Foto 13). Jenis bambu yang dipakai untuk saung seling adalah bulo panyut bila' atau bulo panyut bileng: Saung seling hanya dimiliki oleh orang tertentu keturunan bangsawan. Selanjutnya akan dibahas dalam bagian kebudayaan.

\section{e. Tali dan bahan pengikat}

Hampir setiap perlengkapan yang telah disebutkan di atas membutuhkan tali untuk mengikat. Begitu pula dalam kegiatan seharihari, sering kali ada keperluan untuk mengikat barang-barang. Hasil penelitian ini menunjukkan bahwa ada empat sampai delapan jenis tali dan bahan pengikat yang dibutuhkan per rumah tangga per desa. Dari jenis tersebut $88 \%$ sampai $96 \%$ diperoleh dari tumbuhan liar di hutan. 
Foto 13. Topi saung seling dan persediaan untuk anyaman (Apau Ping)

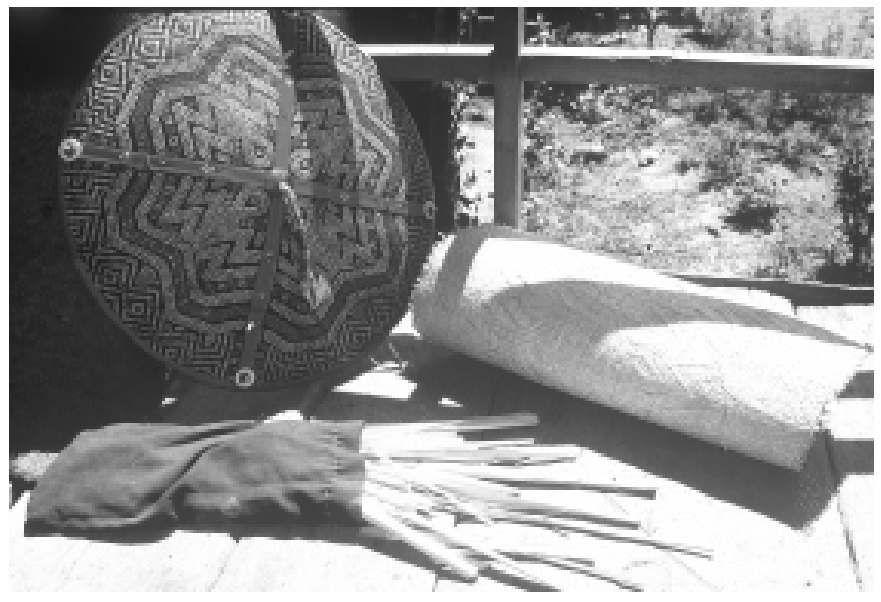

Berdasarkan hasil wawancara, masyarakat di sekitar TN Kayan Mentarang membedakan tali dengan bahan pengikat. Tali dan bahan pengikat dapat berfungsi sama yaitu untuk mengikat sesuatu dalam kegiatan sehari-hari. Tali lebih cenderung dikategorikan sebagai alat yang sudah jadi melalui proses pengolahan bahan baku tertentu, umumnya lebih kuat, lebih indah, dan lebih tahan lama. Sehingga tali ini dipakai untuk keperluan jangka panjang dan dapat dipakai di tempat umum. Jenis-jenis tali yang dimaksud ada dua macam yaitu tali te' bala dan tali te' pute'(te'= kulit kayu). Dalam penggunaan sehari-hari kedua jenis tali ini digunakan pada alat-alat sebagai berikut: tali ki'ba (tali untuk alat gendongan ke ladang atau ke hutan), tali belanyat (tali untuk sejenis tas yang indah terbuat dari rotan), tali ingen (tali yang dipakai pada alat menggendong padi), tali sikep (tali yang dipakai pada alat untuk menangkap ikan), tali ba' (tali yang dipakai pada alat untuk menggendong bayi), tali saung (tali yang dipakai pada sejenis topi yang lebar diikat di kepala agar tidak lepas diterbangkan angin), tali biru (tali untuk membuat jerat), dan lain-lain. Bahan tali ini berasal dari serat kulit kayu yang pohonnya tumbuh liar di hutan antara lain: talun (=dengeng. 
Artocarpus elasticus) menghasilkan tali te' bala, dan kayu te' (Goniothalamus sp.) menghasilkan tali te' pute'.

Sedangkan sebutan bahan pengikat dipakai untuk jenis bahan yang dipakai langsung tanpa diolah, misalnya lemba' (Musa sp.) diambil pucuk yang muda dibelah-belah lalu dikeringkan kemudian dipakai untuk menjahit saung sang (topi). Lidi daun sang (Licuala valida) yang masih muda dipakai untuk mengikat atap yang terbuat dari daun. Jenis-jenis rotan adalah yang paling banyak dipakai, contohnya uwai seka (Calamus caesius), uwai tebungen (Calamus ornatus), uwai semule (Calamus sp.), uwai seringan (Calamus sp.). Bahan pengikat lainnya adalah jenis liana yang disebut dengan nama aka (liana), misalnya aka te' ayang (Bauhinia semibifida), aka tat (= akar berduri: belum diidentifikasi), aka kelesei (Spatholobus ferrugineus), aka kelesei atuk (Spatholobus sp.), aka padem (Meremia sp.), aka kepun (Rhizanthes sp.), dan lain-lain. Semua jenis liana ini dipanen dari yang tumbuh liar di hutan. Liana yang tumbuh di bekas ladang jarang digunakan karena kebanyakan bahan pengikat ini dibutuhkan pada saat kegiatan di hutan. Bahan pengikat ini biasanya digunakan untuk mengikat pondok apabila bermalam di hutan sehingga membutuhkan bahan yang praktis. Selain itu biasa juga dibutuhkan untuk mengikat binatang buruan, misalnya babi diikat dengan tali lalu dihanyutkan di sungai, sekali-sekali ditarik apabila tersangkut.

\section{f. Daun untuk pembungkus makanan, atap dan kerajinan}

Hasil penelitian ini menunjukkan bahwa setiap rumah tangga di sekitar TN Kayan Mentarang menggunakan 6 sampai 11 jenis daun per rumah tangga per kampung. Dari jenis-jenis daun tersebut $48 \%$ sampai 67\% dipanen dari hutan liar dalam waktu satu tahun 199596. Sebagian daun ada yang dipanen dari hasil yang ditanam di kebun. Daun-daun tersebut dimanfaatkan untuk berbagai keperluan dalam kehidupan sehari-hari.

Kebiasaan hidup masyarakat sehari-hari suka makan nasi lembek yang disebut ma'lema'(lihat Foto 14) atau Iuba' laya (atau kalau nasi dicampur dengan talas disebut ma' upa'), baik untuk 
Foto 14. Membuat ma' lema'di Apau Ping

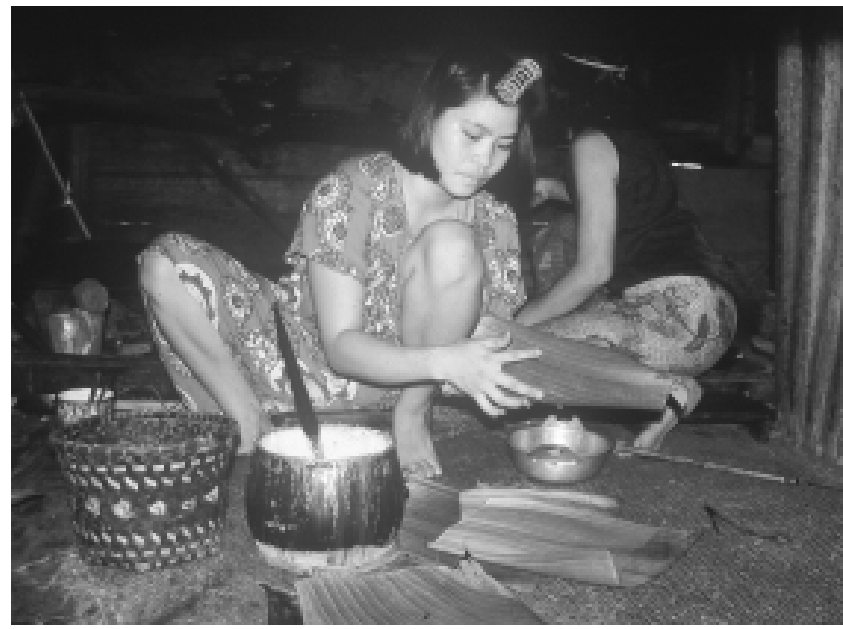

dimakan di rumah maupun untuk bekal ke ladang atau ke hutan. Nasi lembek ini biasanya dibungkus dengan daun. Kebiasaan ini lebih sering ditemukan pada saat ada upacara atau pesta. Selain untuk bungkus nasi, kue-kue yang disebut saga juga dibungkus dengan daun. Daun-daun yang biasa digunakan adalah daun njuk (Maranta arundinacea), daun dalui (Halopegia blumei), daun nyanding (Etlingera elatior), daun pedek (Macaranga triloba), daun kayu kubung (Macaranga gigantea), daun utai (Musaspp.), daun sang (Licuala valida), dan lain-lain.

Selain daun untuk pembungkus ada juga daun yang digunakan untuk atap, terutama di pondok di ladang. Daun-daun ini biasanya dirakit sedemikian rupa, ditusuk dengan tali yang nampaknya seperti dijahit sehingga rapi dan tidak bocor. Ada beberapa jenis daun yang telah disebutkan di atas juga dapat digunakan sebagai atap, seperti: sang dan daun dalui. Jenis daun yang juga baik digunakan adalah daun birai (Salacia affinis var. borneensis), daun kian (Artocarpus odoratissimus), dan daun jaunglan (Zingiber sp.).

Ada beberapa jenis daun yang digunakan untuk bahan kerajinan tangan. Daun-daun tersebut antara lain: daun da'a (Pandanus cf. Kaida) untuk tapung da'a (topi), daun sang (Licuala valida) (lihat 
Foto 15) untuk saung (sejenis topi yang lebar yang dipakai pada saat bekerja di ladang untuk pelindung panas) (lihat Foto 16). Jenis-jenis kerajinan dibahas lebih lanjut dalam bahasan kebudayaan.

Semua jenis daun yang disebutkan di atas ditemukan di hutan liar. Ada kecenderungan sekarang masyarakat menanam di pula (kebun) antara lain: daun dalui (Halopegia blumei) dan daun da'a (Pandanus if. kaida) ditanam hanya untuk kepentingan daunnya saja, daun nyanding (Etlingera elatior) ditanam untuk diambil umbut, bunga, buah, dan daunnya, kian (Artocarpus odoratissimus) untuk diambil daun dan buahnya, dan peti (Musa paradisiaca) untuk diambil daun, bunga, dan buahnya.

Foto 15. Ragi disimpan dalam daun sang dengan bawing sebagai pengawet

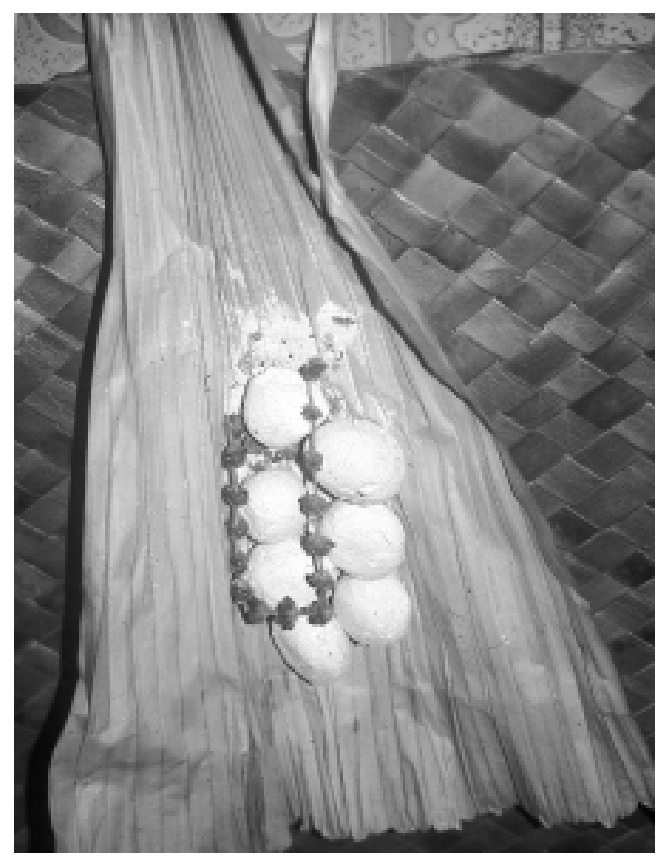


Foto 16. Ibu-ibu memakai saung sambil cari ikan di L. Alango

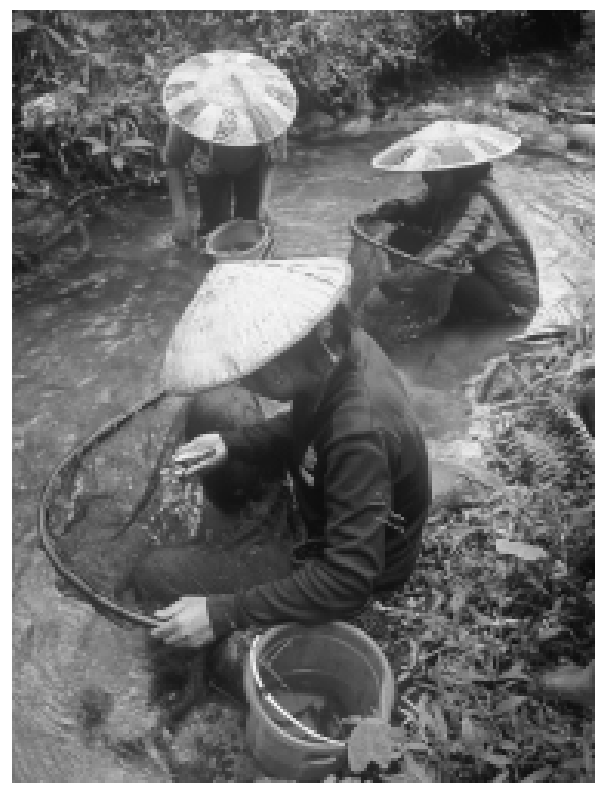

\section{g. Damar untuk dempul perahu dan penerangan pengganti minyak tanah}

Damar atau resin disebut tu'dan merupakan zat ekstraktif yang mengeras berbentuk padat yang berasal dari berbagai jenis tumbuhan di dalam hutan. Damar ini dapat mencair apabila dipanaskan dan bersifat sebagai perekat yang dapat menyatu dengan kayu, kemudian mengeras lagi setelah dingin. Sifat damar seperti ini baik untuk mendempul perahu. Mula-mula damar ini ditumbuk halus lalu dipanaskan sehingga mencair seperti lem yang disebut lisan. Untuk menambal perahu apabila ada kebocoran, terutama pada sambungan bagian-bagian papannya, damar cenderung lebih disukai karena damar tidak tembus air (lihat Foto 17).

Selain itu damar juga dapat dimanfaatkan untuk penerangan apabila menginap di hutan. Damar penting sebagai barang substitusi di masa krisis ekonomi seperti sekarang ini, dan juga penting waktu terjadi kemarau panjang di mana harga minyak tanah melambung 
tinggi dan kadang-kadang persediaan tidak ada. Khususnya untuk orang yang tinggal lama di dalam hutan. Sebagai contoh berdasarkan pengamatan dan pengalaman bersama orang Dayak di hutan. Orang yang mencari gaharu menebang pohonnya yang dilakukan siang hari kemudian dipotong kecil-kecil. Bagian batang yang ada isinya dibawa ke pondok. Sampai di pondok, di malam hari mereka membersihkan gaharu tersebut dengan menggunakan damar sebagai penerangan. Gaharu dibersihkan dengan cara meraut dengan pisau kecil. Hanya gaharu yang bersih yang mereka bawa pulang, sehingga tidak perlu menggendong kotoran yang berat. Untuk bekerja di hutan orang lebih cenderung menggunakan damar sebagai lampu, sebab tidak harus menggendong minyak yang berat dari rumah dan dapat lebih hemat dari segi uang untuk beli minyak. Pada waktu hujan, apabila kayu api banyak yang basah, maka damar inilah sebagai penyulut yang pertama. Setelah damar menyala cukup besar baru kemudian kayunya bisa terbakar.

Masyarakat yang membutuhkan damar dapat mengambil di dalam hutan yang dihasilkan dari beberapa jenis tumbuhan. Ratarata per keluarga memperoleh damar yang berasal dari tiga sampai lima jenis tumbuhan, di mana tumbuhan penghasil damar tersebut

Foto 17. Menambal perahu dengan damar (tu'dan) di Apau Ping
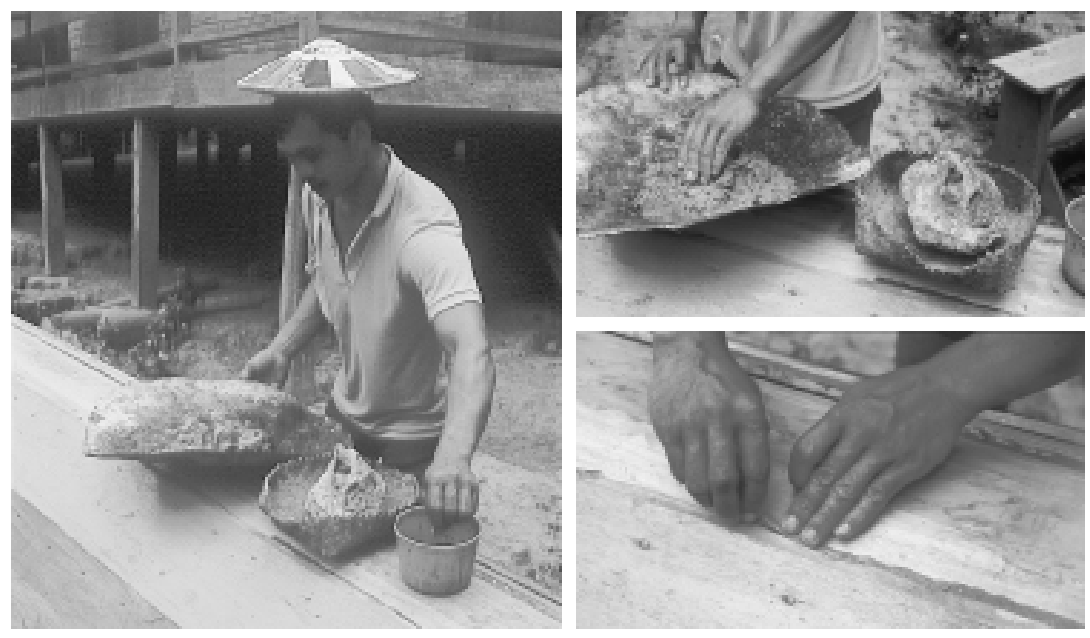
$100 \%$ berasal dari hutan rimba. Kayu-kayu penghasil damar adalah kayu tumu (Agathis borneensis), dan hampir semua jenis dari famili Dipterocarpaceae terutama kayu kapun (Dryobalanops lanceolata), penjae (Hopea mengerawan), dan lain-lain. Keperluan terhadap damar ini hanya sedikit saja. Setiap keluarga membutuhkan sekitar 1\% sampai 5\% saja dari seluruh kebutuhan yang lain.

\section{B. HUTAN MERUPAKAN KEBUTUHAN MASYARAKAT DAYAK SECARA LANGSUNG DAN TIDAK LANGSUNG}

Secara langsung ataupun tak langsung masyarakat Dayak di sekitar TN Kayan Mentarang membutuhkan hutan untuk memulihkan kesuburan tanah. Hutan juga dibutuhkan secara tidak langsung untuk perlindungan sumber air. Selain itu ada masyarakat yang secara langsung ataupun tak langsung mengambil bibit tumbuhan untuk ditanam di kebun. Anak babi hutan untuk bibit ternak juga ada yang ditangkap di hutan.

\section{Ketergantungan Masyarakat Dayak terhadap Hutan untuk Memulihkan Kesuburan Tanah}

Sebagian lahan hutan yang berada dalam wilayah desa difungsikan untuk membuat ladang untuk menanam padi. Ladang dalam bahasa Dayak Kenyah disebut uma'(lihat Foto 18). Sistem perladangan ini dilakukan secara gilir balik, berpindah dari lokasi satu ke lokasi lainnya untuk mendapatkan tanah yang subur, kemudian ke lokasi semula apabila lokasi tersebut sudah kembali kesuburannya. Tanah yang sudah digarap dengan ditanami beberapa jenis tanaman berkurang kesuburannya. Tanah ini kemudian ditinggalkan beberapa tahun (ratarata 6 sampai 15 tahun) untuk mengembalikan kesuburannya. Tanah yang telah berkurang kesuburannya ini dibiarkan menjadi hutan agar subur kembali. Hal ini membuat masyarakat Dayak tidak harus memupuk. Pembakaran daun-daun dan ranting pada saat penyiapan 
lahan dapat memperbaiki kualitas lahan dengan meningkatkan kesuburan tanah. Abu sisa pembakaran menambah kesuburan dengan pengembalian mineral yang berasal dari daun dan ranting. Daun dan ranting yang sulit dibusukkan oleh bakteri dan jamur dapat dipercepat melalui pembakaran. Sedangkan panas yang timbul dari pembakaran dapat merubah sifat fisik dan kimia tanah di permukaan.

Foto 18. Ladang (uma) di L. Tebulo

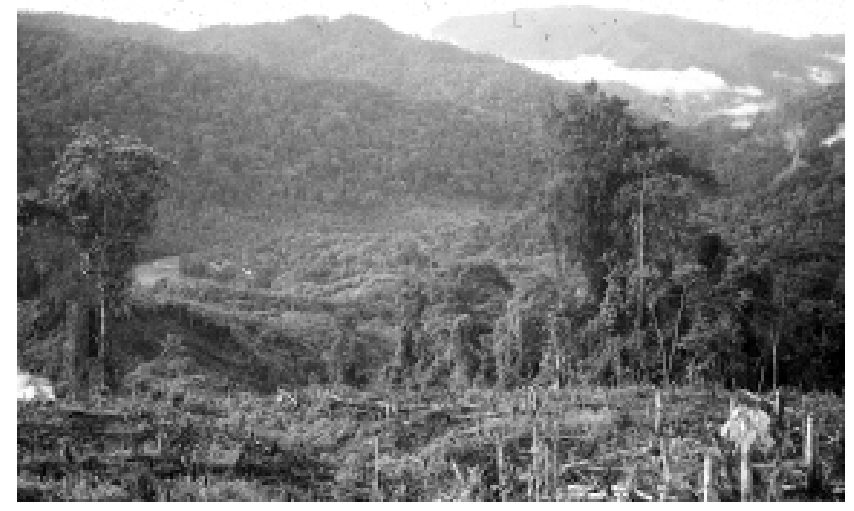

Suatu areal lahan biasanya dikerjakan selama dua sampai lima tahun. Pada tahun pertama ditanami padi, tahun kedua ditanami jagung, kacang-kacangan, dan sayuran, tahun ketiga ditanami singkong, pepaya, pisang, tebu, dan lain-lain. Pada tahun ke empat sampai tahun ke lima biasanya pisang, pepaya dan tebu masih ada, walaupun sudah mulai tumbuh semak di sekitarnya. Tahun berikutnya semak belukar semakin besar tumbuh menjadi hutan sekunder muda. Pada saat ini masyarakat sudah mulai meninggalkannya karena sudah disibukkan oleh kegiatan berladang di tempat lain. Biasanya bekas ladang ini sulit diurus, karena jaraknya yang jauh dari rumah dan berjauhan lokasinya dengan ladang baru.

Ada juga kebiasaan masyarakat yang suka berkebun. Selama memelihara tanaman semusim, mereka menanam tanaman keras seperti beberapa jenis buah-buahan. Akhirnya lahan ini menjadi kebun 
jangka panjang yang disebut pula. Umumnya pula ini dekat dengan kampung. Dalam keadaan tertentu orang Dayak berpindah kampung karena suatu alasan, maka bekas kampung yang disebut lepu' un ini dicirikan oleh adanya kebun buah. Lama-kelamaan lepu'un ini menjadi hutan sekunder yang didominasi oleh pohon buah-buahan.

Jangka waktu yang dibutuhkan untuk memulihkan kesuburan tanah bukan menunggu sampai hutan menjadi dewasa, melainkan hanya beberapa tahun sampai belasan tahun saja sudah digarap lagi. Alasannya karena tanah pada hutan sekunder muda lebih subur dan lebih mudah dikerjakan sebab tidak perlu menebang hutan rimba dengan pohon kayu yang besar-besar. Ladang yang hasilnya baik menandakan bahwa tanah di situ bagus, oleh sebab itu ada kecenderungan lokasi itu akan lebih sering dibuka. Lokasi ini dapat dibuat ladang lagi pada tahun berikutnya, biasanya hanya diulang dua kali saja baru dibuat kebun. Lokasi yang baik ini diolah lagi setelah jekkaunya berumur enam sampai tujuh tahun. Ladang yang biasabiasa saja dapat dikerjakan lagi setelah jekkaunya berumur 15 tahun. Sedangkan ladang yang tidak baik, atau yang gagal panen umumnya tidak diolah lagi. Dibandingkan dengan hasil penelitian lain, Colfer et al. 1997 mengemukakan bahwa jangka waktu yang dibutuhkan selama regenerasi hutan untuk mengembalikan kesuburan tanahnya yang disebut sebagai masa bera kurang lebih sekitar 8 sampai 15 tahun $^{11}$, di Long Ampung sekitar 8 sampai 12 tahun dan di Long Segar sekitar 12 sampai 15 tahun.

Hasil penelitian Riswan dan Kartawinata (1985) dalam Soedjito dan Kartawinata (1987) mengemukakan bahwa hutan sekunder "jekkau" (hutan sekunder yang berumur sekitar 15 tahun) lebih tinggi kesuburannya dibandingkan dengan hutan $\mathbf{m b a}$ '(hutan rimba/primer), berdasarkan analisis kandungan nitrogen pada daundaun dari jenis tumbuhan yang berasal dari hutan sekunder lebih tinggi dibandingkan dengan yang berasal dari hutan rimba (penelitian dilakukan di Long Sungai Barang, Apo Kayan, Kalimantan Timur).

Orang Dayak memiliki pola tertentu dalam sistem pengelolaan tanah dan hutan yang membentuk siklus kurang lebih sama dengan masa bera. Proses pengembalian unsur hara ke dalam tanah secara alami bergantung dari tumbuh-tumbuhan hutan. Dengan 
demikian secara tidak langsung ada ketergantungan terhadap hutan bagi masyarakat Dayak untuk mengembalikan kesuburan tanah. Pola pengelolaan lahan dengan sistem gilir balik seperti ini memungkinkan untuk mengelola lahan tertentu saja dan membiarkan lahan lainnya tetap hutan rimba. Sebagai bukti terakhir sejak perpindahan kelompokkelompok suku yang menempati lokasi-lokasi sekarang menunjukkan masih adanya hutan rimba yang lebat dekat dengan kampung namun tidak digunakan untuk membuat ladang. Hutan rimba ini dipertahankan dan dikelola berdasarkan hukum adat secara lokal, yang disebut tana' ulen (lihat dibawah).

Ada beberapa alasan mengapa orang Dayak cenderung masih suka membuat ladang. Topografi yang bergunung-gunung dengan lereng yang agak curam sulit membuat sawah dan saluran irigasi. Kebanyakan mereka yang memiliki lokasi lahan di tempat datar sudah menggunakan lahannya untuk membuat sawah. Walaupun demikian karena sawah masih dipandang sempit mereka tetap membuat ladang untuk meningkatkan hasil padi selain yang dari sawah. Mereka mengatakan bahwa hasil dari sawah saja tidak cukup. Hasil padi ini biasa dijual untuk membeli berbagai kebutuhan pokok seperti: garam, gula, parang, sepatu belabak, dan lain-lain. Rata-rata ada $5 \mathrm{KK}$ sampai $14 \mathrm{KK}$ atau sekitar 15\% sampai 35\% keluarga per desa mendapatkan uang tunai dari menjual padi. Selain itu orang masih perlu membuat ladang untuk menanam sayur-sayuran seperti: timun, labu, jagung, kacang, ubi, pisang, pepaya, dan lain-lain. Sebagian orang suka membuat ladang karena rasa beras padi ladang jauh lebih enak dan harum dibanding dengan rasa beras padi dari sawah. Sebagian mengatakan karena pengaruh kebiasaan dan tradisi budaya yang sudah turun-temurun dari dulu, sehingga walaupun sudah memiliki sawah mereka tetap membuat ladang.

Mengapa orang Dayak masih suka membuat ladang dengan membuka hutan rimba, alasannya adalah untuk kepemilikan lahan. Menurut hukum adat, siapa yang membuka hutan rimba pertama kali maka merekalah yang berhak memiliki dan mengelola tanah tersebut. Sedangkan jika orang lain mau menggarapnya mereka boleh meminjam selama diberi ijin. Oleh sebab itu mereka membuka hutan rimba untuk mempersiapkan lahan untuk anak-anak mereka. Sebelum 
membuka hutan mereka harus mengadakan rapat dan minta ijin dari kepala desa atau kepala adat. Hal ini hanya kadang-kadang terjadi, biasanya mereka membuka hutan rimba hanya apabila sudah terbentuk rumah tangga baru dalam keluarga, kemudian mereka memisahkan diri dari keluarga orang tuanya dengan membuat rumah baru. Kebanyakan keluarga baru masih tinggal bersama orang tuanya untuk mengelola lahan bersama-sama. Tanda-tanda batas kepemilikan lahan antar penduduk di hutan adalah pohon-pohon, sungai kecil, batu atau tanda alam yang lain.

Beberapa masyarakat lainnya mengatakan bahwa ada kecenderungan masyarakat untuk membuat sawah, karena hasil sawah lebih baik dibandingkan dengan hasil ladang sedangkan hama padi di ladang lebih banyak daripada di sawah. Hal ini disebabkan oleh dekatnya ladang dengan hutan rimba. Hama padi terdiri dari berbagai jenis serangga, burung, dan mamalia kecil dan besar. Hama dari serangga antara lain: tekunyung (=wereng: Nilavarwata lugens), bekulun (=penggerek batang padi: Tryporiza incertulas ), ulet pute' (=larva: Tryporiza incertulas), ulet bileng (=larva: Heliothis armigera), pau (Locusta spp.), asu bulan (Famili: Gryllotalpidae). Hama dari jenis burung yang paling umum adalah: upit saleng (Lonchura fuscans), dan upit bala (Lonchura malacca). Hama dari jenis mamalia kecil adalah belabau uma' (Rattus rattus), dan belabau jami (Rattus tiomanicus). Hama yang merupakan mamalia besar adalah kuyat (Macaca fascicularis), ba'bui (Sus barbatus), dan payau (Cerrus unicolor).

\section{Ketergantungan Masyarakat Dayak terhadap Hutan Sebagai Perlindungan Sumber Air}

Masyarakat membutuhkan air bersih untuk minum, mandi, mencuci, dan sebagainya. Hutan berfungsi untuk mengatur sumber air yang sangat penting bagi masyarakat. Selain air bersih, masyarakat sangat tergantung pada air sungai untuk transportasi, tenaga listrik dan irigasi untuk sawah serta kolam. 


\section{a. Kebutuhan air bersih}

Di hulu Sungai Bahau di mana hutan masih bagus, air sungai tetap mengalir sepanjang tahun. Di musim kemarau juga masih terdapat hujan walaupun dengan intensitas yang lebih kecil. Airnya bersih bebas dari pencemaran. Masyarakat di sana pada umumnya terbiasa dengan keadaan yang alami dan lestari. Mereka khawatir dengan pencemaran lingkungan seperti yang sudah terjadi di daerah Malinau, khususnya di Long Loreh, pada Sungai Benuang ${ }^{12}$ yang dulu merupakan sumber konsumsi masyarakat. Masyarakat di Loreh banyak yang mengeluh tentang air minum, karena Sungai Benuang sekarang sudah tercemar oleh adanya perusahaan batu bara (lihat Foto 19). Pencemaran ini disebabkan oleh lumpur dari dalam tambang yang bercampur dengan air batu bara bekas tampungan hujan. Akibat kandungan lumpur yang pekat ini mengakibatkan air Sungai Benuang secara fisik tidak layak dikonsumsi. Pencemaran ini juga disebabkan oleh limbah oli, minyak solar, dan lain-lain karena ada kegiatan mekanik (bengkel) di sebelah industri pertambangan. Ada juga kekhawatiran masyarakat bahwa dalam kegiatan pertambangan terdapat bahan-bahan kimia yang mengandung racun.

Foto 19. Sungai Benuang yang tercemar oleh perusahaan batu bara (L. Loreh)

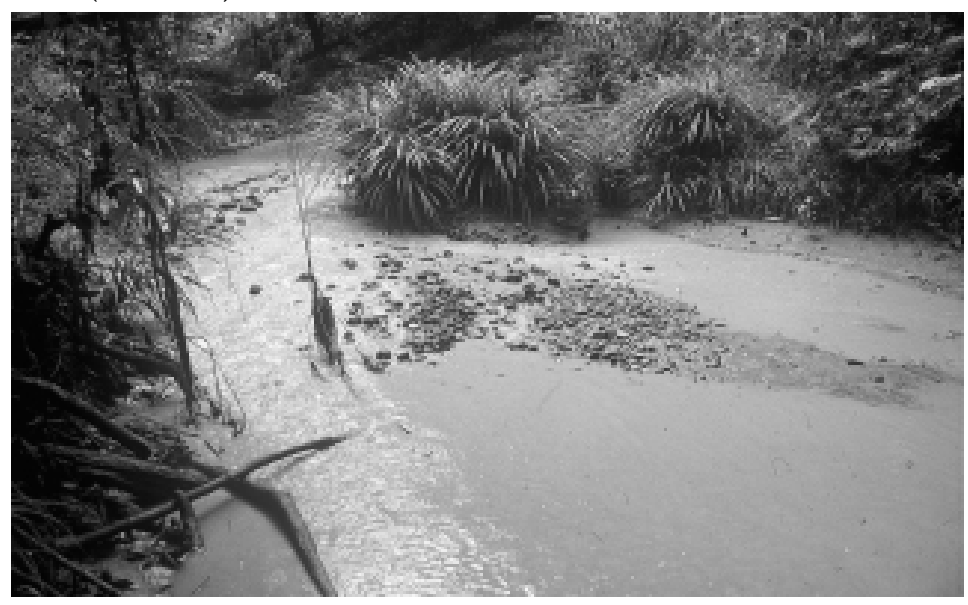


Masyarakat di hulu Sungai Bahau mempunyai hubungan keluarga dengan masyarakat di Long Loreh, maka informasi tentang keadaan air sungai di Long Loreh diketahui oleh masyarakat di Sungai Bahau. Hal ini menimbulkan kekhawatiran masyarakat tentang persediaan air bersih untuk kebutuhan sehari-hari di masa mendatang.

\section{b. Sawah}

Penggarapan sawah sangat tergantung pada persediaan air yang biasanya dialirkan dari anak sungai. Berbeda dengan pola perladangan yang telah dijelaskan di atas, membuat sawah merupakan pola perkembangan baru. Sejak Kepala Adat Besar Hulu Bahau "Apui Njau”" ${ }^{13}$, pada jaman Belanda pulang dari Jawa (konon beliau pernah belajar bersawah selama di penjara Belanda di Batavia) kira-kira tahun 1925-an beliau mengajarkan cara membuat sawah di wilayah Adat Hulu Sungai Bahau. Berkat peninggalan beliau itulah sehingga terdapat banyak sawah di wilayah Hulu Bahau sampai sekarang.

Perkembangan sawah sekarang nampaknya semakin banyak. Karena semakin banyak orang percaya bahwa hasil padi sawah lebih baik. Terutama jika terjadi musim kemarau, maka hasil padi sawah tetap baik, tetapi padi ladang sama sekali tidak baik. Sawah banyak terdapat di Long Tebulo, setiap keluarga yaitu $22 \mathrm{KK}$ atau $100 \%$ keluarga memiliki sawah dengan luas rata-rata 3 ha. Sedangkan di Long Alango luas sawah cenderung bertambah, saat ini ada $63 \%$ keluarga memiliki sawah, terhitung ada $47 \mathrm{KK}$ dari $75 \mathrm{KK}$ memiliki sawah dengan luas rata-rata sekitar 2 ha. Di Long Uli 76\% keluarga mempunyai sawah, dari $17 \mathrm{KK}$ ada $13 \mathrm{KK}$ yang membuat sawah. Di Apau Ping sebanyak 24\% keluarga mempunyai sawah, dari $51 \mathrm{KK}$ ada $12 \mathrm{KK}$ yang membuat sawah. Di Long Berini tidak ada sawah. Di Long Kemuat $100 \%$ keluarga mempunyai sawah. Di Long Peliran ada $5 \mathrm{KK}$ yang membuat sawah dari jumlah keluarga $12 \mathrm{KK}$. Sedangkan di Pujungan hanya sedikit petani yang mempunyai sawah, yaitu hanya $5 \mathrm{KK}$ dengan luas rata-rata 0,5 ha. Di Long Aran ada 4 KK dengan rata-rata 0,25 ha. 
Ada juga pendapat bahwa jika sawah dikerjakan terusmenerus, maka lama kelamaan tanahnya akan tidak subur lagi. Alasan ini juga yang menyebabkan mereka kembali ke ladang. Sebagian orang mengatakan, bahwa walaupun padi ladang itu subur, tetapi kalau tidak mendapat air akan tidak ada buahnya. Sebaliknya, walaupun padi sawah itu kurus tetapi tetap ada buahnya. Ada juga yang mengatakan bahwa kesuburan di sawah itu tetap saja. Sawah peninggalan Apui Njau dari tahun 1925 masih dikerjakan sampai sekarang kurang lebih sudah berusia 75 tahun, namun masih tetap subur. Di Long Tebulo orang sudah mengerjakan sawah selama lebih dari sepuluh tahun tetapi masih tetap subur. Namun pada umumnya beberapa orang yang punya sawah juga mengerjakan ladang. Selama dua tahun belakangan ini banyak keluhan dari masyarakat, karena panen padi di ladang gagal akibat musim kemarau panjang (lihat Foto 20). Banyak di antara mereka yang ingin mengerjakan sawah saja. ${ }^{14}$

Hasil padi sawah cenderung lebih stabil, sedangkan hasil padi ladang kadang banyak kadang sedikit sekali. Jika dibandingkan hasil rata-rata per ha antara padi ladang dan padi sawah, maka padi sawah lebih banyak hasilnya. Sebagai contoh, ladang seluas 4 ha membutuhkan

Foto 20. Dampak kemarau panjang pada hutan di L. Alango (Agustus 1990)

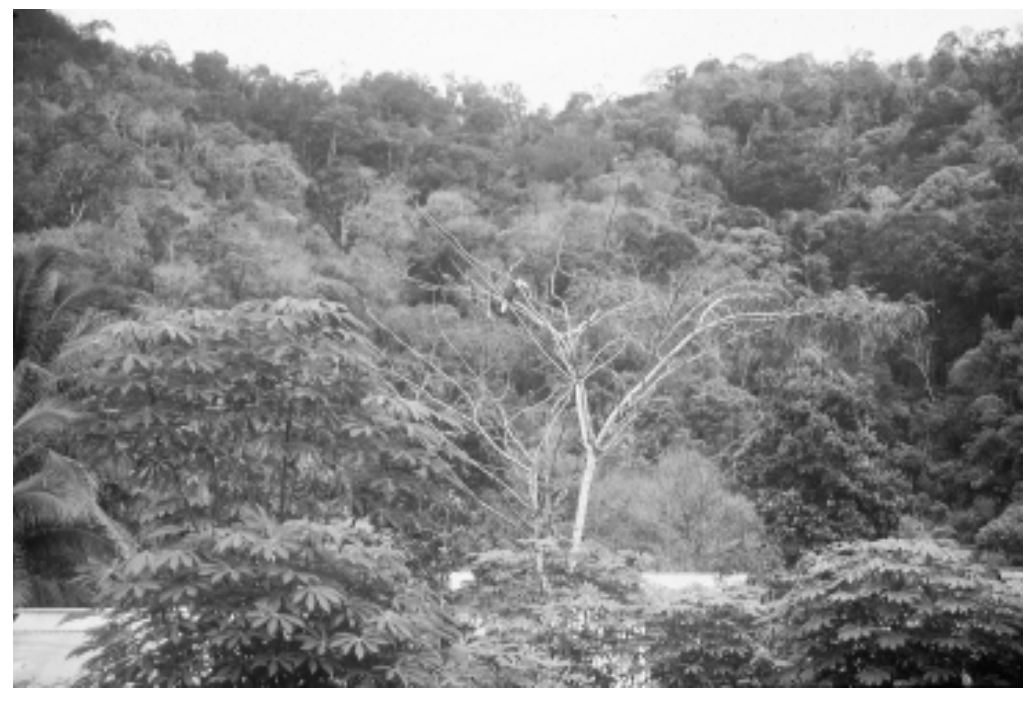


bibit rata-rata 6 kaleng (1,5 kaleng per ha). Hasil ladang semuanya kurang lebih 100 kaleng ( 25 kaleng per ha). Luas sawah 2 ha membutuhkan bibit rata-rata 1 kaleng (0,5 kaleng per ha). Hasil sawah semuanya 80 kaleng (40 kaleng per ha). Hasil padi sawah jauh berlipat ganda dibandingkan hasil padi ladang. Perbedaan curahan waktu dan tenaga kerja antara padi sawah dan padi ladang belum jelas di Hulu Bahau, tetapi menurut beberapa orang, padi sawah lebih ringan.

\section{c. Kolam ikan}

Pada perkembangan belakangan ini nampaknya banyak masyarakat yang mulai membuat kolam ikan yang disebut beng atuk (Leppo' Ké). Kebutuhan air untuk kolam dialirkan dari anak-anak sungai yang mata airnya berasal dari lereng-lereng gunung yang berhutan lebat. Banyak jenis ikan yang sudah dikembangbiakkan di kampungkampung di Hulu Sungai Bahau. Kolam dibuat pertama kali di Long Alango pada tahun 1957-58 oleh Apui Njau dengan membawa ikan mujair dari Tanjung Selor. Kemudian banyak orang yang memelihara ikan di Long Alango dengan membuat kolam di sebelah timur kampung, sampai sekitar tahun 1970-an. Setelah itu timbul anggapan dari masyarakat, bahwa dengan adanya kolam di sebelah timur kampung lama-kelamaan dapat mengakibatkan erosi dari rembesan air yang mengalir di bawah kampung ke arah barat menuju Sungai Bahau. Akibatnya bisa menghanyutkan kampung tersebut. Dengan adanya anggapan ini banyak orang berhenti membuat kolam.

Kemudian pada bulan Februari 1997 pertanyaan itu diajukan kepada staf World Wide Fund for Nature (WWF) Kayan Mentarang yang kebetulan melakukan pertemuan di Long Alango. Dialog dengan masyarakat waktu itu, staf WWF Kayan Mentarang menyatakan bahwa tidak apa-apa bila dibuat kolam di sebelah timur kampung. Penyebab erosi bukan kolam melainkan jika kayu-kayu di pinggir sungai di tebang, maka akar-akar yang mengikat tanah akan mati dan tanah akan mudah longsor. Setelah itu sekitar tahun 1998-99 banyak lagi orang membuat kolam sampai sekarang. Ada sekitar 40\% rumah tangga di Long Alango memiliki kolam khusus untuk ikan. Sedangkan 
beberapa keluarga lainnya memelihara ikan di sawah. Di Long Tebulo sekitar 50\% keluarga memiliki kolam ikan secara khusus dan ada juga yang memelihara ikan di sawah. Di Apau Ping hanya satu keluarga yang memiliki kolam ikan. Ikan yang paling banyak dipelihara di kolam, yaitu ikan mujair dan ikan mas yang didatangkan dari Tanjung Selor atau Tarakan. Bibitnya dapat dipesan dengan naik pesawat MAF. Ikan ini cepat berkembang biak dan cocok di air tenang. Selain bibit ikan yang didatangkan dari luar ada juga ikan yang ditangkap di Sungai Bahau dipelihara di kolam. Sampai saat ini banyak jenis ikan sungai yang sudah dipelihara termasuk yang hanyut melalui saluran air yang berasal dari bendungannya di hulu sungai.

Di depan telah disebutkan bahwa rata-rata ada sekitar 73\% sampai $100 \%$ ikan dipanen dari yang hidup secara liar. Berarti ada sekitar 0\% sampai 27\% dipanen dari hasil budidaya atau kolam. Adanya kolam dapat memenuhi konsumsi ikan sewaktu-waktu apabila diperlukan secara tiba-tiba, misalnya kedatangan tamu, ikan di kolam menjadi simpanan yang mudah diambil. Selain itu, memelihara ikan di kolam juga dapat mengurangi penangkapan ikan liar di sungai, sehingga kelestarian ikan di alam bisa dipertahankan. Di lain pihak, ada kemungkinan dampak ikan peliharaan yang didatangkan dari luar ini terhadap ekosistem liar apabila nanti ada yang terlepas ke sungai. Ikan mujair yang cepat berkembang biak dapat menjadi pesaing bagi jenis ikan yang hidup di habitat aslinya di sungai. Dampak ini belum jelas sekarang.

\section{d. Pembangkit listrik tenaga air}

Sejak tahun 1990an air sungai juga dibutuhkan sebagai pembangkit listrik tenaga air (PLTA). Dengan menggunakan PLTA masyarakat memperoleh listrik untuk penerangan, TV, radio, tape, untuk dinamo mesin penggilingan padi, mengetam kayu, dan lain-lain.

Ada enam desa yang sudah menggunakan PLTA di hulu Sungai Bahau. PLTA pertama kali dibuat di Long Alango pada tahun 1993, mula-mula secara swadaya lalu dibantu oleh Menteri Kehutanan Djamaludin Suryohadikusumo pada tahun 1996. Di lokasi Apau Ping 
dibuat PLTA pada tahun 1994 oleh orang Swis (anggota misi dari gereja) untuk keempat desa yaitu Desa Apau Ping, Long Pengayan, Long Tua, dan Long Lat. Di Long Tebulo dibuat PLTA pada tahun 1994 secara swadaya, dan masih rencana untuk membuat PLTA di Long Berini dan Long Kemuat. Penggunaan PLTA ini tidak menimbulkan pencemaran udara, dan menghemat pengeluaran uang karena mengurangi konsumsi bahan bakar minyak. Lestarinya hutan di hulu sungai dapat menyediakan air dalam jumlah yang konstan sehingga listrik tetap berjalan.

\section{Ketergantungan Masyarakat Dayak terhadap Hutan sebagai Sumber Genetik Bibit Tumbuhan atau Binatang}

Orang Dayak suka menanam bibit tumbuhan yang bermanfaat bagi mereka. Tumbuhan ini biasanya ditanam dekat rumah yang disebut pula (kebun). Apabila mereka pindah kampung maka bekas kampung dengan kebun buahnya ini di sebut lepu' un. Di hutan diambil bibit tumbuh-tumbuhan yang baik, dipilih berdasarkan pengalaman mereka untuk mendapatkan hasil yang lebih baik dan lebih banyak. Bibit tumbuhan yang diambil dari hutan masih sedikit jenisnya, sebagai contoh: dian da'un (Durio oxleyanus), dian kalang (Durio ribethinus), isau bala (Dimocarpus longan ssp1.), isau bileng (Dimocarpus longan ssp2.), bua' a'bung (Nephelium ramboutan-ake), bua'sanggit (Nephelium lappaceum), bua' unjing (Nephelium maingayi), berenyiu (Mangifera caesia), mangga (Mangifera indica), alim (Mangifera pajang), nakan (Artocarpus integer), kian (Artocarpus odoratissimus), basut (Artocarpus lanceifolius), bitung (Garinia mangostana), langset (Lancium domesticum), payang (Pangium edule), kayu me (Cinnamomum burmanni), uwai seka (Calamus caesius) (lihat Foto 21), daun dalui (Halopegia blumei), bekkai lan (Pycnarhena cauliflora), bekkai lanya (Coscinium miosepalum), belengla (Litsea cubeba), uba tepuh (Eugenia sp.) sejenis daun salam, ulem (Solanum torum), dan lain-lain. Jenis-jenis ini sudah ditanam di kebun-kebun dari dulu. Di masa mendatang mungkin lebih banyak lagi bibit tumbuhan yang dibutuhkan. 
Foto 21. Uwai seka (rotan) yang diambil dari hutan untuk ditanam di kebun (Apau Ping)

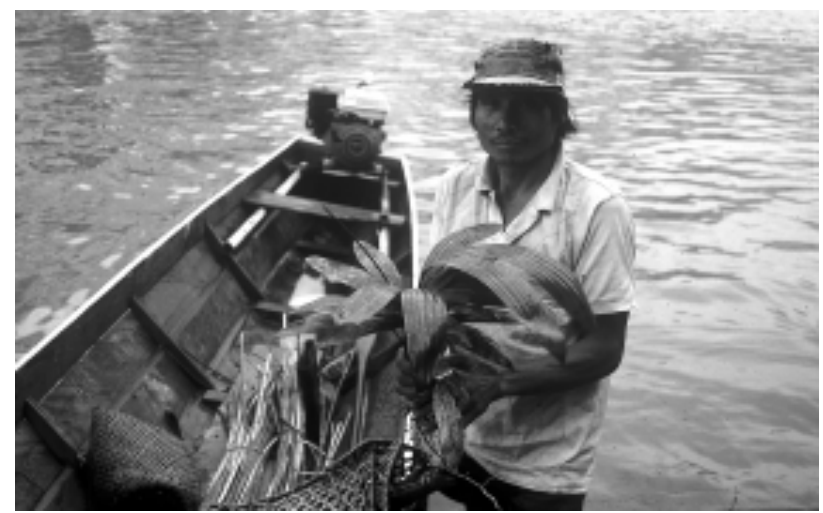

Hasil penelitian ini menunjukkan bahwa baru sedikit saja tumbuh-tumbuhan yang dibudidayakan untuk ditanam di kebun. Hasil dari hutan liar lebih besar dibandingkan dengan hasil pertanian. Telah disebutkan bahwa hasil pertanian berkisar antara 11\% sampai $25 \%$ saja. Berdasarkan hasil perhitungan data bahwa buah-buahan yang dipanen dari hasil budidaya pertanian atau penanaman di kebun berkisar antara 62\% sampai $83 \%$, selebihnya dipanen dari yang tumbuh liar di hutan. Sayur-sayuran yang dipanen dari hasil budidaya berkisar antara $15 \%$ sampai $28 \%$. Kayu yang dibudidayakan masih sangat sedikit, sekitar 5\% sampai $6 \%$ yang dipanen dari yang ditanam mungkin karena masih banyak tersedia di hutan liar, bambu dan rotan sekitar 1\% sampai $5 \%$ dihasilkan dari tumbuhan yang ditanam, obat dan bahan kesehatan kulit sekitar $57 \%$ sampai $64 \%$, bumbu $27 \%$ sampai 30\%, daun untuk bungkus, atap dan kerajinan tangan sekitar 33\% sampai 52\%, bahan upacara 36\% sampai 56\%.

Bibit tumbuhan yang berasal dari hutan liar ini memiliki genetik $^{15}$ yang beraneka ragam. Orang Dayak bisa memilih jenis-jenis tumbuhan untuk dijadikan bibit sesuai dengan sifat genetik yang dimilikinya, seperti rasa manis, buahnya banyak, buahnya yang besar, dan sebagainya. Keanekaragaman genetik ini akan dibutuhkan di masa mendatang untuk memenuhi berbagai kebutuhan hidup manusia 
seperti: bahan makanan, obat-obatan, perkakas dan sebagainya. Kebutuhan terhadap suatu genetik tertentu berubah sesuai dengan keadaan alam, selera masyarakat, dan konsumsi pasar. Tersedianya berbagai genetik tumbuhan dan makhluk hidup di hutan merupakan cadangan berbagai kebutuhan umat manusia di masa yang akan datang.

Selain bibit tumbuhan, bibit binatang sudah ada yang dimanfaatkan antara lain: ba'bui (babi hutan: Sus barbatus) dan payau (Cerrus unicolor). Sebagai contoh, babi hutan sering ditangkap pada saat berenang menyeberangi sungai. Anak babi hutan yang masih kecil ditangkap kemudian dipelihara di rumah. Pada waktu masih kecil anak babi hutan ini terus menerus diberi makanan sehingga menjadi jinak. Hal ini sering dilakukan di Long Alango. Ada sekitar 10\% sampai 15\% rumah tangga di hulu Sungai Bahau memelihara babi hutan. Babi hutan sangat mudah menyesuaikan diri dengan makanannya. Babi dapat makan singkong, talas, dan sisa-sisa nasi yang tidak dimakan lagi. Pemeliharaan babi hutan ini dapat memberi kesempatan untuk melakukan kawin silang dengan buin (babi peliharaan: Sus domesticus), untuk mendapatkan bibit unggul yang tahan terhadap penyakit, mudah mengurus makanannya, cepat besar dan gemuk. Pemeliharaan babi dapat menggantikan daging binatang buruan, sehingga konsumsi binatang dari alam bisa dikurangi untuk dilestarikan.

Sedangkan bibit ikan yang berasal dari sungai yang sudah dibudidayakan ada beberapa jenis. Pak Jan Lawai di Long Alango mengatakan bahwa ia lebih banyak memelihara jenis ikan yang bibitnya diambil dari Sungai Bahau. Contohnya ikan selareng (=patin: Pangasius sp.), salap (Barbodes balleroides), padek (Tor if. tambra), kati (=lele: Chana sp.), betelo (Rasbora sp.), dan lain-lain. Selain bibit ikan yang diambil secara sengaja di sungai, juga ada bibit ikan yang kebetulan masuk ke kolam ikut aliran air dari hulu sungai yang jenisnya bermacam-macam. 


\section{Ketergantungan Masyarakat Dayak terhadap Ekosistem Hutan sebagai Hubungan yang Saling Terkait}

Secara langsung ataupun tidak langsung orang Dayak sangat tergantung pada ekosistem hutan. Hutan merupakan sumber makanan dan perlindungan berbagai jenis satwa yang membentuk interaksi yang saling terkait. Jika salah satu jenis satwa terganggu maka satwa yang lain juga dapat terganggu. Begitu pula jika hutan terganggu maka tempat mencari makan orang Dayak akan terganggu yang akibatnya hasil buruan mereka juga berkurang. Akibat selanjutnya, jika tidak ada pilihan lain maka makanan orang Dayak juga berkurang. Oleh sebab itu orang Dayak melindungi hutan tertentu agar selalu mendapatkan binatang buruan. ${ }^{16}$

Dalam kaitannya dengan ketergantungan orang Dayak terhadap ekosistem hutan ini dapat dijelaskan dari kehidupan mereka tentang cara mencari nafkah. Orang Dayak mengamati beberapa indikasi sebagai ciri di mana dan kapan ada binatang. Berdasarkan indikasi ini maka orang Dayak mudah mendapatkan binatang buruan. Ada suatu tempat yang disukai oleh binatang untuk minum ataupun mencari makanan. Juga ada cerita orang Dayak tentang hubungan babi dengan lebah, babi dengan $\boldsymbol{d u k}$, dan babi dengan kupu-kupu dalam kaitannya binatang ini mencari makan di dalam hutan. Di sungai juga orang Dayak mengamati perilaku ikan dan di mana ikan biasa terdapat dalam jumlah banyak.

\section{a. Sungan dan ketina' ba'bui tempat berburu}

Di dalam hutan terdapat tempat binatang biasa minum yaitu di sumber air asin yang disebut sungan. Orang Dayak sudah tahu di mana tempat-tempat sungan tersebut. Binatang yang biasa minum air sungan adalah bangat (Presbytis hoser) dan uca' ano (Muntiacus muntjac) biasanya waktu pagi sekitar jam 9 sampai jam 10 dan sore sekitar jam 3 sampai jam 4. Sedangkan yang biasa minum waktu malam hari adalah payau (Cerrus unicolor). Sungan ini biasanya terdapat di pinggir 
anak-anak sungai yang kecil. Sungan ini dilindungi oleh orang Dayak. Siapapun yang datang berburu di sungan ini tidak boleh menebang kayu atau memotong pohon-pohon kecil di sekitarnya. Mereka khawatir kalau sungan ini rusak maka binatang tidak mau lagi minum di sana.

Selain sungan ada juga tempat babi berkubang yang disebut ketina' ba'bui. Ketina' ini biasa terdapat di pematang gunung, di lereng, dan di tempat-tempat biasa air tergenang. Ketina' ada yang berbentuk kubangan biasa seperti kolam dan ada juga yang berbentuk lubang seperti goa. Di ketina' ini biasanya babi tidur.

Orang Dayak berburu dengan mengintip binatang buruan di sungan atau di ketina' dengan menggunakan bujak atau sumpit. Selanjutnya dijelaskan pada bagian lain dalam tulisan ini.

\section{b. Hubungan babi dan duk dimanfaatkan untuk berburu}

Ada suatu cerita tentang pola babi dan $\boldsymbol{d} \boldsymbol{u k}$ dalam mencari makanan. Menurut orang Dayak di mana ada musim buah yang banyak, ke situ babi hutan berpindah mencari makanan. Babi yang berpindah ini mengikuti jenis monyet yang disebut duk (Macaca nemestrina). Babi dan duk membentuk hubungan yang saling menguntungkan (simbiosis mutualisme). Duk makan buah di atas pohon sambil menjatuhkan kulit dan bijinya. Sedangkan babi di bawah pohon memakan jatuhan sisa-sisa duk tersebut dari atas. Kadang-kadang babi juga dapat buah yang baik. Kalau babi sudah kenyang makan, maka babi tidur di tanah. Kemudian $\boldsymbol{d u k}$ turun untuk mencari kutu babi untuk dimakan. Biasanya babi banyak sekali kutunya. Babi senang dicari kutunya karena mengurangi rasa gatal maupun sakit di badannya. Duk senang karena mendapat makanan enak. Inilah sebabnya babi suka mengikuti duk. Jika ada suara duk maka babi akan datang ke sana. Dengan pengetahuan ini, maka orang Dayak sering menirukan suara dukuntuk menipu babi agar datang mendekat. Jika sudah dekat langsung dibujak (ditombak). Cara berburu seperti ini disebut ngeduk. Selanjutnya akan dijelaskan pada bagian kebudayaan. 
Hampir semua jenis buah-buahan di hutan disukai oleh $\boldsymbol{d u k}$ dan babi. Di mana buah-buahan ini terdapat dijadikan indikasi bahwa di situ biasa ada babi dan duk. Sebagai contoh buah-buahan yang paling disukai yaitu: settai (Baccaurea macrocarpa), lepesso (Baccaurea lanceolata), konye (Baccaurea parriflora), keramo' (Dacryodes rostrata), mejalin (Xanthophyllum scortechinii), mejalin batu (Xanthophyllum excelsa), isau bala (Dimocarpus longan ssp1.), isau bileng (Dimocarpus longan ssp2.), bua' a'bung (Nephelium ramboutan-ake), bua' sanggit (Nephelium lappaceum), bua' unjing (Nephelium maingayi), berenyiu (Mangifera caesia), mangga (Mangifera indica), alim (Mangifera pajang), adiu (Garcinia forbesii), bitung (Garcinia mangostana), langset (Lancium domesticum), penjae (Hopea mengerawan, =laran ba'bui artinya buah laran yang suka dimakan babi), bua' palan (Lithocarpus nieuwenhuisii), bua' palan timai (Lithocarpus conocarpus), bua' bangan (Castanopsis argentea), bangan su'et (Lithocarpus coopertus), nyeliway (Quercus argentata), bua' beta (Parkia speciosa), dan masih banyak buah yang lain.

\section{c. Hubungan babi dan lebah dalam perpindahan dimanfaatkan untuk berburu ba'bui satung}

Menurut pengalaman orang Dayak ada hubungan antara babi dan lebah waktu perpindahan ke lokasi lain. Konon babi berpindah mengikuti lebah, di mana lebah ini mencium bau bunga yang banyak maka mereka pindah melawan arus angin mencari sumber bau bunga tersebut. Umumnya kalau lebah pindah dalam koloni besar suaranya nyaring dan babi mendengar mereka ke mana arahnya. Babi mengikuti arah yang diisyaratkan oleh lebah tersebut. Dalam perjalanannya mereka bertemu dengan pasangannya lalu kawin. Babi hamil sampai di tempat tujuan menunggu musim buah jatuh siap melahirkan anaknya. Anak babi yang baru lahir mendapatkan makanan berlimpah di musim buah.

Perpindahan babi ini sering melewati sungai-sungai besar dekat dengan perkampungan. Apabila musim babi pindah (migrasi) masyarakat suka menghadang di pinggir sungai, karena babi yang 
berpindah biasanya dalam rombongan yang besar sekitar 10 sampai 30 ekor babi dewasa dan bahkan bisa mencapai ratusan jika anak mereka banyak. Saat babi menyeberangi sungai, babi-babi tersebut berenang secara serentak. Musim babi berenang disebut ba'bui satung, ketika babi sedang berenang disebut ba'bui nyatung ${ }^{17}$. Babi yang sedang berenang ini sangat mudah ditangkap, baik dengan bujak (tombak) atau parang (pisau), kadang-kadang ditangkap hidup-hidup jika babi tersebut masih kecil. Babi yang masih kecil ini dipelihara di rumah. Jika sudah besar baru dipotong. (Lihat bab hutan sebagai sumber bibit binatang peliharaan).

\section{d. Kupu-kupu digunakan sebagai tanda musim berburu ba'bui satung}

Kupu-kupu kuning dan hijau di pinggir sungai yang berkelompok dalam jumlah besar digunakan sebagai tanda adanya musim ba'bui satung. Kalau ditanyakan kepada orang Dayak, mengapa kupu-kupu dijadikan ciri untuk musim babi berenang, biasanya mereka mengatakan itu adalah pengalaman dari dulu, katanya.

Cerita ini nampaknya terkait juga dengan perpindahan babi yang mengikuti lebah berpindah pada saat musim bunga. Kemungkinan kupu-kupu ini menetas dari kepompongnya tepat pada saat musim bunga mulai. Pada saat perpindahan babi ini, kupu-kupu suka mengisap garam yang berasal dari kencing dan kotoran binatang. Biasanya babi dalam rombongan yang banyak suka mencari cacing di tempat-tempat becek di pinggir sungai sambil meninggalkan kencing dan kotorannya. Hubungan ekologi antara kupu-kupu dan babi inilah yang digunakan oleh orang Dayak untuk mengetahui kapan ada babi dalam jumlah banyak, terutama untuk berjaga-jaga kemungkinan ba'bui satung.

Jadi hubungan antara musim bunga, perpindahan lebah, kupukupu menetas dari kepompong, musim buah, dan perpindahan babi memiliki siklus secara periodik yang tentunya dipengaruhi oleh iklim dan musim. Saling keterkaitan antara faktor-faktor yang menentukan siklus ini di alam, berperan bagi orang Dayak secara tidak langsung. 


\section{e. Hubungan antara ikan dengan pohon dimanfaatkan saat menjala}

Selain yang telah disebutkan di atas, hutan juga mempengaruhi ikanikan di sungai. Secara tidak langsung tumbuh-tumbuhan di dalam hutan menghasilkan buah-buahan yang merupakan makanan bagi ikan. Hampir semua jenis buah-buahan yang jatuh di sungai dimakan oleh ikan. Jenis buah yang paling disukai oleh paling banyak jenis ikan adalah buah dari berbagai jenis Ficus seperti: bua' lunuk (Ficus stupenda), bua'lunuk nyambung (Ficus xylophylla), bua'lunuk timai (Ficus benjamine), abung aa' (Ficus glomerata), a’bung bileng (Ficus hemsleyana), abung selareng ${ }^{27}$ (Ficus uncinata), dan hampir semua jenis ficus yang lain. Buah pohon yang lain yang juga disukai adalah $\boldsymbol{b u a}^{\prime}$ laran (Dipterocarpus oblongifolius) dan hampir semua buah dari famili Dipterocarpaceae yang lainnya. Buah-buahan seperti isau (Dimocarpus spp.), a'bung (Nephelium spp.), juga banyak dimakan oleh ikan.

Menurut orang Dayak, ikan di hulu sungai lebih enak dibandingkan ikan di hilir (dekat laut). Di wilayah hulu sungai hutan masih bagus, banyak terdapat buah-buahan sebagai makanan ikan dibandingkan dengan sungai di bagian hilir yang tidak ada hutannya. Di musim buah-buahan ikan biasanya gemuk-gemuk. Dari hutan juga banyak terdapat serangga yang jatuh ke dalam sungai. Mungkin karena makanan ikan di dalam hutan lebih bervariasi maka rasa dagingnya lebih enak. Oleh sebab itu keutuhan hutan sangat penting terhadap ekosistem perairan sungai dan secara tidak langsung mempengaruhi daya dukung sumberdaya ikan terhadap kebutuhan masyarakat Dayak.

Di pinggir-pinggir sungai yang ada pohon ficus atau pohon lainnya yang sedang berbuah maka di dalam sungai di bawah pohon tersebut biasanya banyak terdapat ikan. Jika ada buah yang jatuh ke dalam sungai maka ikan-ikan yang sembunyi di bawah batu akan keluar mengejar buah tersebut. Kebiasaan ikan seperti ini sudah diketahui oleh orang Dayak, sehingga jika mereka menjala ikan maka dicari lokasi yang ada pohon di atas sungai. Di bawah pohon ini dilemparkan batu kecil, untuk menipu ikan agar keluar dari persembunyiannya. Ikan akan datang ke tempat batu itu dilemparkan dikira ada buah yang jatuh. Kemudian orang menebarkan jala di tempat tersebut. 


\section{e. Musim dingin digunakan sebagai tanda untuk menangkap atuk pale'.}

Pada bulan-bulan tertentu kondisi udara relatif dingin, air sungai kecil dan jernih karena kemarau. Pada saat itu ada suatu pola di mana ikan-ikan selalu bertelur. Ikan-ikan yang berasal dari sungai besar masuk ke sungai kecil untuk melepaskan telurnya. Biasanya jumlah ikan yang bertelur ini sangat banyak bisa sampai ratusan bahkan lebih. Musim ikan bertelur ini disebut atuk pale' (atuk=ikan, pale'=bertelur dan berkumpul). Sungai-sungai yang biasa dimasuki oleh ikan untuk bertelur hanya anak sungai tertentu saja, dan jenis ikan yang bertelur hanya jenis ikan tertentu untuk satu anak sungai. Ikan lainnya bertelur di anak sungai yang lain. Tetapi bisa juga ikan yang jenisnya berbeda bertelur di sungai yang sama pada musim yang lain. Setelah melepaskan telurnya ikan-ikan tersebut kembali ke sungai besar. Telur ikan tersebut nantinya akan menetas di sungai kecil dan baru masuk ke sungai besar setelah dewasa.

Orang Dayak hafal dengan perubahan iklim ini, ketika udara terasa dingin hal itu menandakan musim atuk pale'. Umumnya orang Dayak sudah siap menjaga di muara sungai untuk memasang pukat. Ikan yang di angkap hanya ikan yang besar-besar saja, sedangkan ikan kecil-kecil akan lolos lewat pukat tersebut. 


\section{Bab 3 \\ Keterkaitan Budaya Masyarakat Dayak terhadap Hutan}

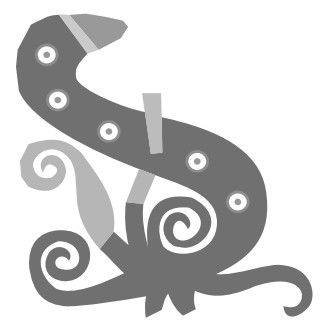

\section{A. PENGETAHUAN DAN KETERAMPILAN UNTUK MEMANFAATKAN HUTAN DAN MENGELOLA HUTAN}

Orang Dayak mewariskan ilmu pengetahuan tradisional untuk memanfaatkan dan mengelola hutan, sehingga orang Dayak terampil hidup di dalam hutan tanpa tersesat, dapat menyelamatkan diri dari binatang buas dan memperoleh makanan di hutan. Dalam mengelola hutan, orang Dayak sangat terampil sehingga tidak menimbulkan kerusakan hutan yang luas. Orang Dayak juga terampil mencari makanan dengan berbagai cara berburu, berbagai cara menangkap ikan, dan mencari sayur dari berbagai jenis tumbuhan.

\section{Di Hutan Tempat Mewariskan Ilmu Pengetahuan Tradisional}

Hutan berfungsi sebagai objek dan tempat belajar untuk mewariskan ilmu-ilmu tradisional dari orang tua kepada anaknya. Di hutan orang tua mengajar anak-anaknya tentang tumbuh-tumbuhan yang bisa dimakan, obat-obatan, tumbuhan beracun, bagaimana mengenal ciri- 
cirinya, apa namanya, dan bagaimana memanfaatkannya. Di hutan orang tua Dayak juga mengajar anak-anaknya berburu, ngasu (berburu dengan anjing), ngeduk (berburu meniru gaya monyet), meleput atau nyumpit (yaitu menembak dengan menggunakan hembusan angin dari mulut melalui pipa pembuluh), menjala, pasang pukat, dan lain-lain untuk mendapatkan nafkah sehari-hari.

Belajar di dalam hutan melalui kebiasaan yang semula ikutikutan masuk ke hutan dari sejak kecil, mereka secara tidak sengaja mendapatkan pengalaman dan pelajaran dari orang tuanya untuk mengenal hutan, cara menyelamatkan diri, dan berbagai cara hidup di dalam hutan. Pengetahuan yang diwariskan secara turun-temurun itu merupakan pendidikan informal yang sangat berharga bagi orang Dayak maupun masyarakat luas apabila dikaji dan dikembangkan lebih lanjut. Sebagai contoh dalam mengenal tanaman obat dan racun, manfaatnya untuk jenis penyakit apa, bagaimana cara pengolahannya, dan sebagainya. Pengetahuan ini juga penting bagi masyarakat luas.

\section{Keterampilan Orang Dayak Dalam Berbagai Cara Berburu dan Menangkap Ikan}

\section{a. Minjung}

Berbagai cara dilakukan oleh orang Dayak untuk memenuhi kebutuhan bahan makanan (lihat juga Puri 1997). Antara lain adalah minjung yaitu berburu dengan cara meleput atau nyumpit. Anak sumpit yang sangat ringan terdorong oleh angin di dalam pipa pembuluh dapat melesat sejauh $100 \mathrm{~m}$. Buruan yang berjarak sekitar 10 sampai $15 \mathrm{~m}$ akan terluka apabila kena oleh anak sumpit tersebut. Biasanya anak panah ini tertancap di tubuh binatang buruan. Anak sumpit yang mengandung racun dapat membunuh binatang sejenis kuyat, kijang, pelanuk, beruang, dan sebagainya dalam tempo satu jam. Pada umumnya binatang yang sudah kena racun pasti mati tidak bisa bertahan hidup. Jenis-jenis burung besar seperti temengang (Buceros rhinoceros) dan teba'un (Rhinoplax irgil) juga bisa mati. Untuk meniup sumpit dengan menghembuskan angin yang kuat dari dalam 
mulut ada cara tertentu dan teknik yang baik yang sudah dikuasai oleh orang Dayak. Perburuan ini diatur dengan beberapa peraturan, terutama untuk babi (lihat bagian hukum adat di bawa).

Sebelum mereka pergi berburu ke dalam hutan mereka harus melihat arah angin. Mereka tidak mau mengikuti arah angin, sebab binatang mencium bau mereka yang dibawa oleh angin. Sebaliknya mereka pergi berburu dengan melawan arah angin. Dengan melawan arah angin ini, binatang buruan dapat ditelusuri di dalam hutan.

\section{b. Mabang sungan}

Selain itu pemburu juga dapat menunggu binatang yang datang minum air asin. Dalam bahasa Dayak Kenyah disebut mabang sungan (mabang $=$ menunggu, mengintai, menghadang; sungan $=$ mata air asin). Biasanya jenis-jenis binatang seperti bangat (Presbytis hoser), uca' ano (Muntiacus muntjac), dan jenis burung punai mba' (Treron curvirostra) suka minum air asin untuk mendapatkan mineral. Jika musim kemarau biasanya di pagi hari sekitar jam 9 sampai jam 10 dan sore hari sekitar jam 15 sampai jam 16, binatang tersebut datang ke sungan. Umumnya mereka berombongan.

Kalau angin baik biasanya binatang tersebut tidak mencium bau manusia, sehingga pemburu dapat berjaga-jaga dekat dengan sungan sekitar 10 sampai $15 \mathrm{~m}$. Pemburu tahu persis di mana mengambil posisi untuk menjaga dan dari mana arah binatang yang akan datang, supaya binatang tidak melihat mereka. Untuk mabang sungan ini mereka membuat tempat persembunyian dari daun-daun kayu yang diatur sedemikian rupa agar mereka terlindung.

Jika binatang sudah datang ke sungan kemudian minum, binatang yang datang pertama tidak disumpit. Binatang itu dibiarkan minum sampai puas, kemudian setelah rombongan berikutnya datang, biasanya lebih banyak, maka boleh disumpit. Jika binatang yang datang pertama disumpit maka rombongan berikutnya tidak mau datang. Jika kelompok bangat ada 11 ekor maka dapat disumpit 8 sampai 10 ekor. Di daerah hulu Sungai Bahau banyak terdapat sungan. Sehingga orang Dayak banyak punya pilihan untuk mengintai sungan yang mana disesuaikan dengan arah angin. 


\section{c. Mabang burung teba'un dan temengang}

Selain mabang sungan orang Dayak juga sering mabang burung teba'un dan temengang di pohon buah lunuk (Ficus xylophylla) atau lunuk timai (Ficus benjamine) yang biasa didatangi oleh burung itu. Sekelompok burung teba'un atau temengang yang datang dapat disumpit sampai semuanya jatuh. Tetapi kejadian ini jarang terjadi. Biasanya hanya dalam lima sampai sepuluh tahun sekali. Sebab bila sudah pernah menangkap burung ini, bulu burungnya bisa tahan sampai sepuluh tahun. Sedangkan menangkap burung ini untuk diambil dagingnya jarang terjadi.

\section{d. Mabang satung}

Di depan telah dijelaskan tentang orang yang mabang satung (menunggu babi berenang pada musim perpindahan babi). Di pinggir sungai pada waktu musim babi berenang banyak sekali orang menunggu dengan membawa senjata berupa bujak, parang, dan ketinting. Jika babi yang datang sudah mulai menyeberang ditunggu sampai dekat ke seberang di tempat orang menunggu. Ada aturan adat tidak boleh menembak babi yang sedang berenang, sebab dikhawatirkan mengenai orang yang ikut mengejar babi tersebut. Senjata yang dipakai hanya bujak dan parang. Selain itu, tidak boleh orang menunggu babi atau pergi berburu ke tempat darimana asal babi tersebut menyeberang.

\section{e. Menjerat binatang dengan peru, labak, dan siang}

Selain cara yang telah disebutkan di atas orang Dayak juga menangkap binatang dengan menggunakan jerat. Ada dua jenis jerat yang umum dipakai yaitu jerat kaki yang disebut peru atau biru dan jerat leher yang disebut labak. Tali jerat ini dibuat dari tali kecil yang kuat dan halus. Jerat dipasang di tempat binatang biasa lewat. Ada jenis binatang tertentu yang memiliki jalan yang sering dilewati sehingga bekasnya 
nampak seperti alur. Di bekas-bekas jalan inilah biasa dipasang jerat. Bisa juga dibuat rintangan-rintangan di dalam hutan kemudian dibuat celah yang disebut awang (tempat jalan binatang) sehingga binatang tergiring ke celah ini. Di celah inilah dipasang jerat. Binatang yang biasa kena jerat jenis peru adalah uca' ano (Muntiacus muntjac), pelanuk (Tragulus javanicus), bekulu (Felis bengalensis), kule upa'(Vivera tangalunga), dan bilut (Echinosorex gymnurus). Sedangkan binatang yang biasa kena jerat untuk jenis labak adalah settung (Thecurus crassispinis), settung umung (Hystrix brachyura), dan bekia (Trichys fasciculata). Kadang ada juga yang memasang benda tajam dari bambu di celah ini yang disebut siang. Binatang yang biasa kena siang adalah payau (Cerrus unicolor), ba'bui (Sus barbatus), dan hampir semua binatang lainnya yang masuk ke situ.

\section{f. Ngeduk}

Cara yang paling unik untuk berburu adalah ngeduk. Di atas telah dijelaskan bahwa ada ketergantungan antara duk (Macaca nemestrina) dengan babi hutan (= $\boldsymbol{b a}^{\prime} \boldsymbol{b u i}$ : Sus barbatus) yang membentuk hubungan timbal balik yang saling menguntungkan. Hubungan baik kedua jenis binatang ini dimanfaatkan oleh orang Dayak untuk berburu. Mereka biasa berburu dengan cara ngeduk yaitu menirukan suara duk. Satu orang dapat berbunyi menirukan suara anak $\boldsymbol{d u k}$ dan induknya secara bergantian sehingga kedengaran seperti ada banyak duk di sekitar sana. Orang yang ngeduk tidak berpakaian yang berwarna mencolok. Mereka hanya menggunakan daun-daun untuk melindungi tubuh dan menyembunyikan badannya. Mereka memanjat pohon sambil menggoyang-goyangkan dahan kayu agar buah jatuh. Jika arah angin baik, maka babi akan datang kemudian menggulingkan badannya di atas tanah. Orang Dayak kemudian mendekati babi tersebut lalu mengelus-elus punggung babi itu sampai tertidur. Jika babi sudah tidur baru dibujaknya. Jika terjadi hal yang tidak menguntungkan sebelum babi dibujak, misalnya arah angin tiba-tiba berubah ke arah babi maka babi itu seketika lari menjauh karena takut kepada manusia. Cara ngeduk dikuasai oleh orang tua yang kebanyakan dilakukan oleh orang Punan dan beberapa subsuku di hulu Sungai Bahau. 


\section{g. Memanggil kijang}

Ada lagi cara yang lain untuk berburu yaitu khusus untuk mencari kijang. Cara ini adalah dengan memanggil kijang tersebut. Untuk menirukan suara kijang digunakan daun kayu ditiup di mulut sehingga menimbulkan suara seperti anak kijang. Induk kijang akan datang mendekat mengira ada anaknya yang memanggil. Si pemburu bersembunyi di balik pohon atau banir sambil mengintip kijang yang datang. Jika kijang yang diincar sudah dekat baru dibujaknya.

\section{h. Menangkap ikan dengan sikep, pancing, jala, dan pukat}

Untuk menangkap ikan biasa digunakan tangguk (sikep, pancing, jala, dan pukat). Sikep adalah alat berupa jaring yang bertangkai dibuat dari tali te' bala. Sikep biasa digunakan pada waktu air banjir dan keruh (lihat Foto 22). Waktu air besar, ikan suka di pinggir-pinggir sungai karena jika di tengah mereka hanyut oleh derasnya air. Karena air keruh ikan tidak bisa melihat orang. Dengan demikian sangat mudah ditangkap dengan sikep. Ada juga orang yang menggunakan pancing dengan tali khusus yang disebut tasi (tase'). Sedangkan jala digunakan bisa pada waktu air keruh maupun waktu air jernih. Tetapi lebih bagus menjala saat air keruh. Pukat biasa dipasang melintang di tengah sungai untuk menangkap ikan yang lewat. Ikan tertangkap karena siripnya menyangkut di pukat. Biasa juga orang memasang pukat di muara sungai kecil sebelum banjir. Apabila banjir datang maka ikan-ikan akan lari berlindung di sungai kecil karena takut hanyut terbawa arus yang deras. Saat itulah ikan tersebut kena pukat.

\section{i. Menangkap ikan dengan bubu dan bading}

Bubu dan bading adalah alat untuk menangkap ikan di sungai berupa perangkap yang dibuat dari bambu dianyam sedemikian rupa bentuknya bulat seperti botol dengan ukuran besar, kurang lebih panjangnya $1 \mathrm{~m}$ (lihat Foto 23). Bedanya adalah, $\boldsymbol{b u} \boldsymbol{b u}$ dipasang di pinggir sungai yang tenang (limbu= belilek), lobangnya menghadap 
Foto 22. Belanyat beta (kanan) dan sikep (kiri)

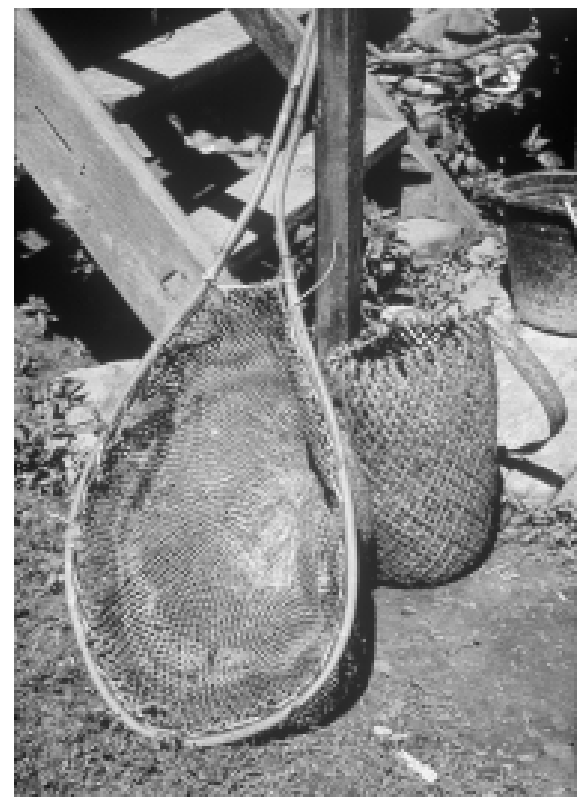

ke hilir. Di dalam $\boldsymbol{b u b u}$ dipasang umpan berupa makanan yang disukai oleh ikan. Ikan berenang ke hulu mencium bau umpan yang hanyut, akhirnya masuk perangkap. Sedangkan bading dipasang di tengah sungai yang deras, lebih di sukai di air terjun. Lobangnya menghadap ke hulu ke arah atas. Ikan-ikan yang hanyut dari hulu semuanya terperangkap di dalam bading. Bading tidak menggunakan umpan.

\section{j. Nyelapang atuk}

Pada waktu musim kemarau apabila air sudah jernih ikan-ikan akan terlihat di dalam sungai. Orang Dayak biasa menyelam untuk menangkap ikan dengan membawa selapang atuk yaitu semacam panah yang anak panahnya diikat dengan tali. Saat menyelam apabila menemukan ikan yang cukup besar, maka dipanah dengan selapang atuk ini. Anak panah ini tertancap di tubuh ikan, kemudian tali 
Foto 23. Bading

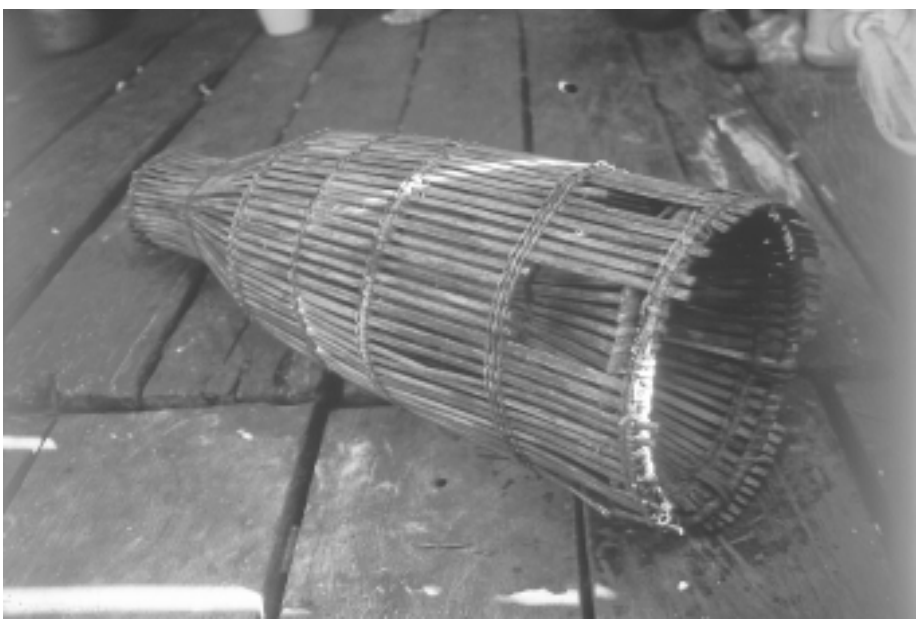

pengikat anak panah ini ditarik. Di ujung anak panah ada kait seperti pancing sehingga ikan tidak bisa lepas. Cara ini sering dilakukan oleh orang laki-laki remaja sampai orang dewasa.

\section{Keterampilan Orang Dayak Dalam Mengelola Hutan}

Orang Dayak melindungi sebagian besar hutannya untuk tempat berburu dan mencari hasil hutan lainnya, tidak semua hutan ditebang untuk dibuat ladang. Hutan yang dilindungi ini disebut dengan tana' ulen. Pengelolaan tana' ulen diatur dengan hukum adat. Tana' ulen selanjutnya dijelaskan pada bagian lain dalam tulisan ini.

Selain adanya tana' ulen yang dilindungi, pemanfaatan hutan lainnya juga diatur dengan ketentuan adat. Misalnya ada aturan bahwa tidak boleh menebang pohon atau semak dekat dengan sungan agar binatang tidak terganggu atau takut. Jika ada orang berburu ingin mengambil daun untuk persembunyian harus dibawa dari jauh.

Jika membuka hutan rimba untuk membuat ladang juga tidak boleh sembarangan, masyarakat harus bermusyawarah dulu baru boleh mulai menggarap. Sedangkan untuk mengelola padang alang- 
alang orang Dayak juga punya cara tertentu. Umumnya orang Kenyah yang tinggal di Apau Ping dan orang Punan yang tinggal di Sungai Lurah, mereka membakar padang alang-alang secara rutin. Padang alang-alang yang habis dibakar umumnya akan tumbuh tunas baru yang sangat digemari oleh kijang, payau, banteng, dan binatang pemakan rumput lainnya. Menurut mereka jika alang-alang tidak dibakar maka akan tumbuh semak-semak, lalu alang-alangnya hilang sehingga binatang yang suka makan rumput akan menjauh. Sebaliknya jika alang-alang rutin dibakar maka selalu ada rumput muda yang menyebabkan binatang buruan mendekat.

Sampai saat ini terdapat padang alang-alang yang luas di hulu Sungai Bahau yaitu di Long Tua dan yang lebih luas di Long Pe. Di daerah Sungai Lurah di bekas-bekas kampung perpindahan sukusuku dulu yaitu Sungai Bawang cabang Sungai Bena dan di pinggir Sungai Lurah antara Sungai Apan dan Sungai Ketawan masih terdapat alang-alang yang sering dibakar secara rutin untuk memancing binatang buruan. Pembakaran alang-alang ini tidak dilarang karena tidak mengganggu ladang. Padang alang-alang di Long Tua dipakai untuk berburu saja.

Cara orang Dayak untuk membakar padang alang-alang maupun membakar ladang adalah dengan melihat arah angin. Dengan pengetahuan mereka yang sudah turun-temurun secara tradisional, mereka melakukan pembakaran tanpa menimbulkan kebakaran hutan yang luas di sekitarnya. Jika ada yang dengan sengaja membakar hutan atau padang alang-alang tanpa musyawarah yang dapat merugikan orang lain maka orang itu didenda berdasarkan hukum adat yang berlaku. Selanjutnya mengenai hukum adat dijelaskan pada bagian lain dalam tulisan ini.

Pada jaman dulu jika masyarakat memanen hasil hutan seperti gaharu dan rotan dan hasil hutan lainnya juga ada aturan adat. Sebelum memanen hasil hutan mereka melakukan upacara yang disebut bada' taro. Jika tidak melakukan upacara ini maka tidak boleh memanen hasil hutan. Cara memanen hasil hutan tersebut juga memperhatikan kelestarian hasil. Misalnya dalam memanen rotan yang masih muda yang panjangnya kurang dari $5 \mathrm{~m}$ tidak boleh ditebas atau dipotong. Begitu juga gaharu yang belum ada isi tidak boleh ditebang. Upacara 
ini kurang dilakukan sekarang, cara memanen hasil hutan kebanyakan dituangkan dalam hukum adat tentang tana' ulen (selanjutnya dijelaskan pada bagian upacara).

\section{B. HUTAN SEBAGAI TEMPAT UNTUK MENGAMBIL BAHAN-BAHAN UPACARA DAN KEBUDAYAAN}

\section{Bahan Upacara}

Masyarakat Dayak di sekitar TN Kayan Mentarang banyak mengambil bahan-bahan yang berasal dari hutan sebagai bahan upacara. Setiap rumah tangga per desa memakai rata-rata dua sampai enam jenis bahan upacara pada tahun 1995-96. Dari jenis-jenis tersebut sekitar $44 \%$ sampai $64 \%$ dipanen dari hutan liar. Keperluan terhadap bahanbahan upacara mulai berkurang sejak masuknya agama Kristen, khususnya di daerah Sungai Bahau sekitar tahun 1957 sampai 1973. Sebelum tahun 1957 masyarakat masih ngadet, yaitu memiliki kepercayaan sendiri berdasarkan adat. Sejak tahun 1957 beberapa kampung mulai memeluk agama Kristen, kemudian pada tahun 1973 hampir setiap warga sudah memeluk agama Kristen.

Walaupun mereka telah beragama Kristen namun peninggalan kepercayaan yang dulu, masih ada sampai sekarang dan masih sangat berguna terutama di saat-saat ada kejadian atau peristiwa yang tidak dapat dipecahkan berdasarkan agama dan jauh dari pertolongan dokter. Kepercayaan terhadap adanya hantu dan roh jahat masih ada sampai sekarang. Untuk mengusir roh-roh jahat dan makhluk halus serta penangkis hantu digunakan beberapa jenis tumbuh-tumbuhan yang berasal dari hutan. Tumbuh-tumbuhan yang masih sering dipakai dalam kehidupan sehari-hari contohnya adalah sekau (Aquilaria beciariana, dan A. malaccensis), pa'ung lung (Homalomena cordata), kerenga'(Acarus calamus), simang (sejenis pohon, tidak diketahui). Beberapa jenis tumbuhan ini sering dipakai bekal jika masuk hutan untuk menghilangkan rasa takut. Apabila ada rasa takut bahan-bahan ini dibakar, baunya harum. Ada juga orang yang menaruh bahan ini di gendongan bayi atau di ayunannya agar bayi terlindung dari 
pengaruh setan. Semua jenis tumbuhan ini dimanfaatkan dari dulu dan merupakan tumbuhan asli Kalimantan, namun sekarang kebanyakan sudah ditanam di halaman atau di kebun.

Sebelum masyarakat memeluk agama Kristen ada upacara adat yang dilakukan untuk berdoa setelah memanen hasil hutan, mendoakan hasil panen, merayakan kepala yang dipotong, serta membuang sial dan cuci kampung. Upacara ini disebut melaki, artinya suatu kepercayaan terhadap burung pelaki (Haliastur indus). Sebelum mengenal Tuhan Yesus, Dewanya orang Kenyah adalah Jalung Peselong Luan, pencipta dunia. Orang menyembah dia dan percaya dia melalui binatang, seperti: uca' ano (Muntiacus muntjac), isit (Arachnothera longirostra), ukeng (Sasia abnormis), pelaki (Haliasturindus), suwi payau (Meiglyptes tukki), dan lain-lain. Lewat binatang-binatang itulah pesan dari Tuhan disampaikan kepada manusia.

Ada beberapa cara orang melakukan upacara melaki berdasarkan tujuannya serta suku yang melakukannya. Upacara melaki yang dilakukan dengan tujuan untuk memanen hasil hutan disebut bada' taro. Orang tidak boleh memetik hasil hutan tertentu apabila tidak melakukan upacara bada' taro. Setelah melakukan upacara ini baru hasil-hasil hutan yang diinginkan boleh diambil seperti: uwai (semua jenis rotan), da'a (Pandanus kaida), dan suling (Glochidion arborescens). Upacara melakiyang dilakukan dengan tujuan untuk mendoakan hasil panenan disebut malan uman biasanya dilakukan oleh seorang paren (bangsawan) dibantu oleh seorang panyen (orang biasa). Upacara ini biasanya dilakukan setelah nu'gan (tanam padi) berulang-ulang setiap bulan sampai selesai potong padi. Selama itu orang yang malan (pantangan bagi pelaku upacara) tidak boleh potong rambut. Setelah selesai potong padi baru upacara ini selesai dan orangnya boleh potong rambut. Upacara melaki yang dilakukan dengan tujuan untuk membuang sial disebut muwe'leppo' atau cuci kampung. Bahan yang digunakan untuk melakukan upacara melaki adalah nyanding, tilo iyap (telor ayam), iyap (ayam), dan sin bu'in (daging babi peliharaan). Ada juga beberapa subsuku Dayak di beberapa kampung mengatakan bahwa melakijuga bisa dilakukan untuk menyembuhkan orang sakit. Sedangkan beberapa subsuku yang 
lain di kampung lainnya mengatakan bahwa untuk menyembuhkan orang sakit dilakukan upacara yang disebut belian.

Cara melakukan upacara melaki untuk menyembuhkan orang sakit adalah sebagai berikut: Ada suatu tempat khusus di gunung sebagai tempat suci untuk melakukan upacara melaki. Upacara melaki dilakukan oleh seorang dukun atau pawang paren dibantu oleh seorang panyen, sedangkan orang di kampung tidak boleh pergi ke luar rumah. Mereka yang pergi ke luar kampung membawa parang, tombak, beras, panci untuk masak di hutan. Kalau ke sana harus melangkahi batas antara kampung dengan tempat suci itu, berupa tanda silang dari batang nyanding dengan baca-baca (doa-mantra) oleh dukun. Orang yang pergi ke gunung itu membawa satu ekor ayam, lemak babi, dan daging untuk dimakan oleh burung pelaki. Barang-barang ini diletakkan di dalam tempat khusus yaitu belanyat beta. Anak-anak membawa beras yang direndam di dalam air.

Sebelum memotong ayam, dukun tersebut memanggil burung pelaki dengan membaca mantra sambil memutar-mutar tangan ke atas. Mantranya sebagai berikut: "Oo bali pelaki, nai na nggin udip, udip dado, udip co', udip tiga, udip magad", artinya: "Ya, Tuhan melalui burung pelaki, datanglah membawa hidup, umur panjang, hidup baik, hidup bersemangat". Mantra ini dibaca berulang-ulang sampai burung pelaki datang. Burung akan terbang memutar-mutar di atas tempat melakukan upacara ini. Ada isyarat yang diberikan oleh burung pelaki tersebut, apabila terbangnya berputar berlawanan dengan permintaan dukun maka orang sakit yang sedang didoakan tersebut akan meninggal. Apabila terbangnya sesuai dengan permintaan dukun maka orang sakit tersebut akan sembuh.

Kalau burung pelakinya sudah datang lalu diberi makan. Ayam dipotong ditusuk kepalanya lalu ditancapkan di situ dan diberi lemak babi, daging, dan beras. Batang nyanding dipotong kemudian dipukul-pukul sampai hancur lalu diletakkan di bawah ayam yang dipotong supaya darah ayam menetes di batang nyanding. Orang memanggil berteriak-teriak, “'ma', ma”. Siapa yang mengambil nasi itu diolesi darah dari nyanding tersebut. Badan ayam dibawa pulang untuk dibuat bubur. Di kampung dipotong babi untuk memberi makan orang banyak di rumah orang yang sakit. Orang-orang tidak 
boleh mandi sebelum dukun menentukan boleh mandi. Ada pertanda yang dipakai untuk menentukan sudah boleh mandi atau belum, yaitu belanyat beta yang dipakai ke gunung tadi tidak boleh dibawa masuk ke dalam rumah, tetapi disimpan di luar rumah. Apabila belanyat beta ini sudah hilang (mungkin dibawa oleh dukunnya ke sungai untuk mandi) maka orang sudah boleh mandi. Hanya dukunnya yang boleh mandi pertama kali. Kalau ini dilanggar bisa membawa sial. Ada juga cara lain, apabila anak-anak sudah kepanasan dan bosan menunggu, mereka datang mengecek belanyat beta ini. Kalau belanyat ini masih ada, maka mereka membawa air di dalam bambu untuk membasahi kepala dukun tersebut. Apabila dukun sudah keramas dengan air tersebut maka anak-anak sudah boleh mandi.

Upacara belian dilakukan untuk menyembuhkan orang sakit apabila hanya ada satu orang saja yang sakit. Bahan yang dipakai adalah bete (belum diidentifikasi), nyanding (Etlingera elatior), tubo (= tubo bunyau, =pula suwi tak, tumbuhan parasit belum diidentifikasi), udu tukak (Phyllanthus urinaria), dan sengangang (Mustela nudipes). Apabila orang yang sakit banyak jumlahnya dan biasanya banyak terjadi orang meninggal di kampung itu, keadaan ini disebut layu, maka dilakukan upacara yang disebut mendeng long. Bahan yang digunakan adalah pa'ung lung (=lung adek. Homalomena cordata) ditaruh di pagar sekeliling rumah. Orang dulu memakai rumah panjang yang berpagar. Upacara ini biasanya dilakukan tiga hari. Selama melakukan upacara ini semua orang tidak boleh keluar rumah. Semua makanan dan air disiapkan sebelumnya.

\section{Bahan Kebudayaan}

Berbagai jenis kebudayaan yang berasal dari berbagai suku yang terdapat di sekitar TN Kayan Mentarang diwariskan secara turuntemurun. Kebudayaan yang beraneka ragam ini cenderung berkaitan dengan kehidupan alami di hutan. Barang-barang yang paling umum dibuat sampai sekarang adalah: tapung da'a (topi) dibuat dari daun da'a (Pandanus kaida) dihiasi dengan bulu burung teba'un (Rhinoplax irgil) (lihat Foto 24) dan temengeng (Buceros rbinoceros), udeng (anting- 
Foto 24. Anting-anting dari kepala burung teba'un

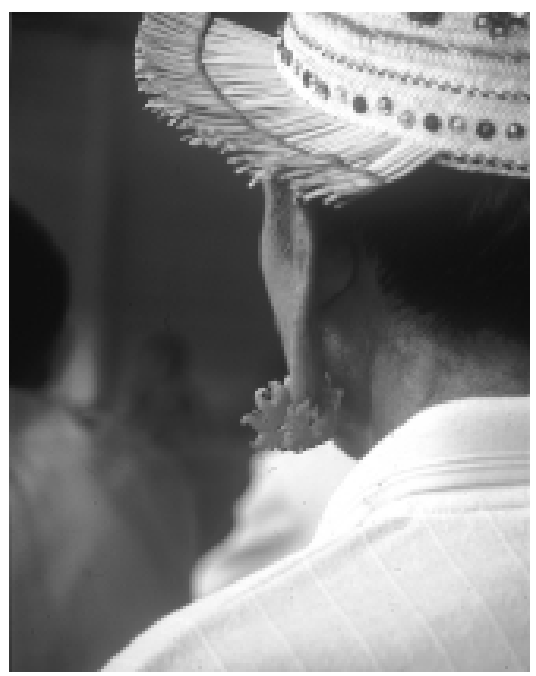

anting) dibuat dari kepala teba'un (Rhinoplax igil), sambe'(alat musik) dibuat dari jenis kayu adau (Elmerrillia mollis) dan njau lutung (Dyera costulata), dan sapai talun (baju yang dibuat dari kulit kayu) dibuat dari jenis-jenis pohon talun dengeng (Artocarpus elasticus), dan talun temai (Artocarpus altilis). Barang-barang kebudayaan ini dipakai sewaktu ada upacara-upacara penting seperti pesta pernikahan, pesta perpisahan, kunjungan pejabat penting negara, dan tahun baru.

Bahan-bahan untuk membuat barang-barang kerajinan untuk kebudayaan ini sebagaimana telah dijelaskan di atas berdasarkan sumber bahan bakunya, jumlah jenis yang dipanen per desa per KK, serta prosentase pengambilannya di hutan liar. Khususnya bahan untuk sapai talun (lihat Foto 25a dan 25b) rata-rata ada satu jenis tumbuhan untuk membuat kain dari kulit kayu yang dipanen per rumah tangga di Long Alango pada tahun 1995-96, sedangkan untuk desa Apau Ping dan Long Pujungan tidak ada yang panen. Jenis-jenis tumbuhan tersebut $100 \%$ dipanen dari hutan liar. Sedangkan jenis kayu yang digunakan sebagai bahan pewarna adalah seleman (Weinmannia blumei) dan suling (Glochidion arborescens). Bahan pewarna 
untuk lukisan, pewarna kain, dan cat tapan dipanen sekitar empat sampai lima jenis per rumah tangga per desa (lihat Foto 26). Dari jenis tersebut $98 \%$ sampai $100 \%$ berasal dari hutan liar.

Foto 25. Kulit kayu talun dipakai untuk membuat pakaian tradisional di L. Alango (25a dan 25b)

(a)

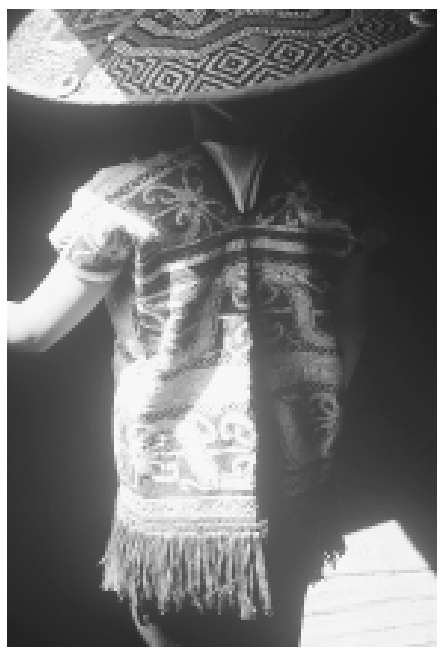

(b)

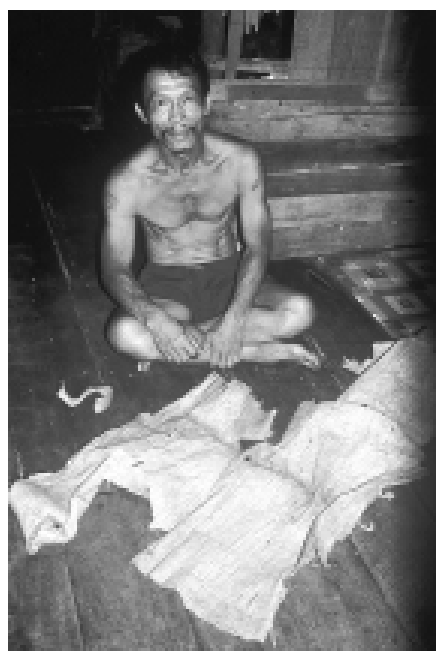

Foto 26. Kayu ainguntuk membuat pewarna (Apau Ping)

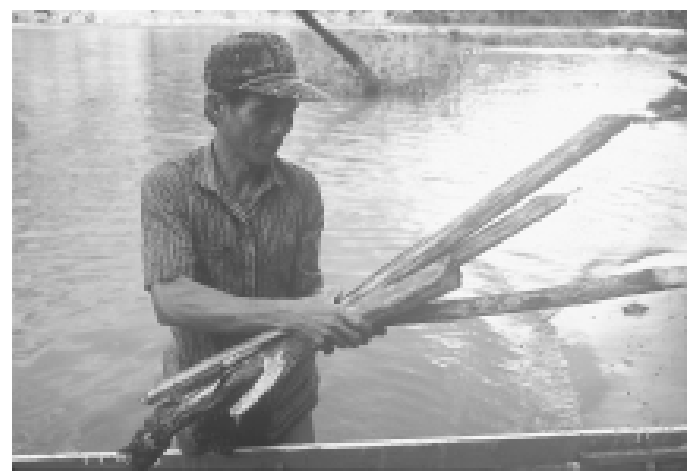




\section{Tari-tarian dan Lagu-lagu Meniru Kehidupan di Hutan}

Untuk kebudayaan kesenian berupa tari-tarian digunakan pakaian khusus. Pakaian yang digunakan oleh laki-laki disebut besunung yaitu baju yang dibuat dari kulit binatang (lihat Foto 27). Kulit binatang yang sering digunakan untuk orang dewasa adalah kule lenjau (Pardofelis nebulosa), kule bilung (Pardofelis marmorata), buang (Helartos malayanus), dan iko temengang (ekor Buceros rhinoceros) dianyam sedemikian rupa untuk menghiasi baju. Untuk anak-anak dibuatkan besunung dari kulit bangat (Presbytis hosei) sebab kulit binatang ini kecil. Sedangkan wanitanya memakai pakaian dengan hiasan dari manik-manik saja disebut ta'a. Pada jari tangan mereka memakai kirip yaitu sayap burung teba'un (Rhioplax igili) yang diikatkan di jari tengah, dipakai oleh laki-laki maupun perempuan (lihat Foto 28). Selain itu juga memakai topi yang dihiasi bulu burung. Topi untuk laki-laki disebut tekeleng dihiasi ekor burung teba'un. Untuk topi wanitanya disebut tapung puk dihiasi bulu burung temengang saja.

Foto 27 . Penari yang pakai besunung

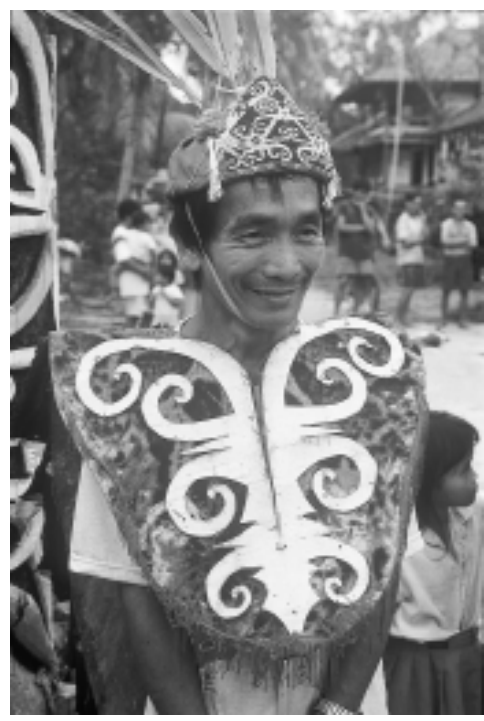


Foto 28. Penari yang pakai topi dari bulu burung teba'un dan temengang

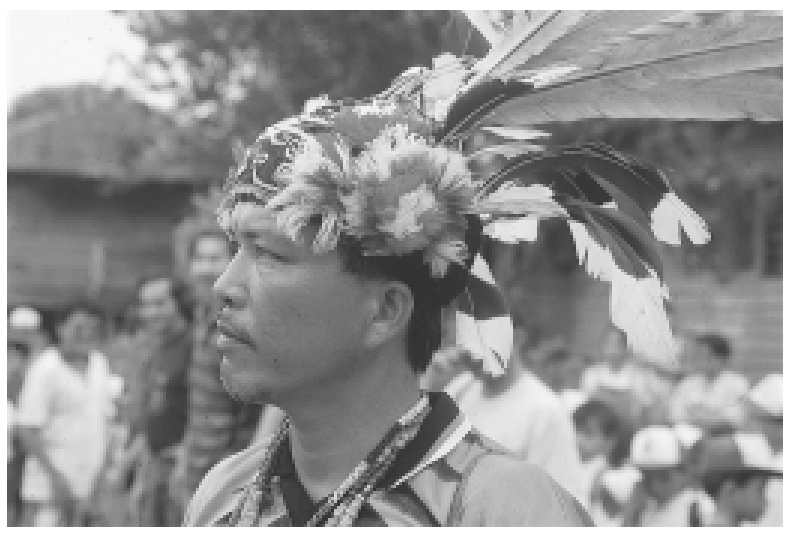

Ada tari-tarian untuk wanita yang menirukan burung kuwai (Argusianus argus) dan temengang (Buceros rhinoceros). Untuk laki-laki tariannya seperti minjung (berburu burung), meleput (berburu dengan sumpit), ngejala (menjala ikan). Tari-tarian ini diiringi oleh musik sambe'(semacam gitar) dan lagu-lagu yang mengalun indah. Lagu yang dilantunkan secara bersahut-sahutan juga biasanya berkaitan dengan kisah sesuatu di alam, misalnya lagu tentang burungburung kesayangan atau burung peliharaan yang berjudul kulung kuwai (Argusianus argus), kulung punai (Treron currirostra), kulung kuju (Egretta egret), kulung nyakilang (Colocalia esculenta). Tari-tarian yang lain misalnya pepatai yaitu tari perang untuk mempertahankan wilayah atau berebut wanita.

\section{SIMBOL STATUS SOSIAL DAN NAMA-NAMA ORANG DAYAK MENGAMBIL CONTOH DARI HUTAN}

Dalam kehidupan masyarakat Dayak banyak menggunakan simbolsimbol yang berasal dari hutan. Simbol-simbol ini biasa terdapat dalam lukisan, ukiran, dan anyaman pada benda-benda yang menjadi ciri khas kebudayaan Dayak. Ukiran yang terdapat pada sarung mandau, ukiran pada mandaunya, ukiran pada perahu, anyaman manik-manik yang terdapat pada bening (gendongan bayi), saung seling, belanyat 
dan lain-lain merupakan simbol status sosial dan kekayaan. Di tempattempat umum misalnya balai desa, balai pertemuan umum, ruang tunggu di lapangan terbang dan di tempat-tempat umum lainnya dapat dijumpai lukisan di dinding dengan simbol-simbol dari hutan atau alam. Di lapangan sepakbola di kampung biasanya terletak di depan balai pertemuan umum, terdapat tiang yang disebut tilang berukir burung temengang dan ila'. Di depan perahu di bagian hulunya yang disebut julung (kepala perahu) biasa terdapat ukiran naga.

\section{Simbol Status Sosial}

Simbol-simbol yang berasal dari hutan yang digunakan oleh orang Dayak antara lain: burung temengang (Buceros rhinoceros), teba'un (Rhinoplax irgil), kabuk (Varanus rudicollis) (lihat Foto 29a dan 28b), kule lenjau (Pardofelis nebulosa), kule bilung (Pardofelis marmorata), baya'(Crocodylus porosus), lengunan (naga), sapuk (bunga), dan lainlain. Menurut adat dalam status sosial, orang paren (bangsawan) menggunakan simbol tertentu di mana orang panyen (orang biasa) seharusnya tidak boleh memakainya. Tetapi sistem ini mulai berubah sekarang, pemakaian simbol-simbol ini mulai bercampur. Orang panyen sering memakai simbol yang seharusnya hanya dipakai oleh orang paren. Dulu orang yang melanggar tersebut didenda, tetapi sekarang ini tidak ada lagi larangan ataupun denda.

Simbol yang dipakai oleh orang paren misalnya temengang, kule lenjau, dan kabuk, simbol ini biasa terdapat pada gendongan bayi. Simbol untuk orang panyen yaitu kalung nyain (ukiran polos), atau pendeng (seperti ikat pinggang berhiasan bunga). Ukiran yang terdapat pada mandau ataupun pada sarungnya biasanya gambar kabuk untuk paren dan untuk panyen biasa polos saja. Mandau juga merupakan simbol kekayaan. Makin banyak seseorang memiliki mandau maka semakin kaya lah orang tersebut. Ada juga yang menggunakan gambar orang "ila" (ukuran manusia), tergantung asalusul keturunan bangsawan tersebut. Gambar ila'yang paling banyak digunakan adalah pada saung seling yaitu sejenis topi lebar lambang bangsawan. 
Foto 29. Kabuk di (a) balai desa dan (b) mandau

(a)

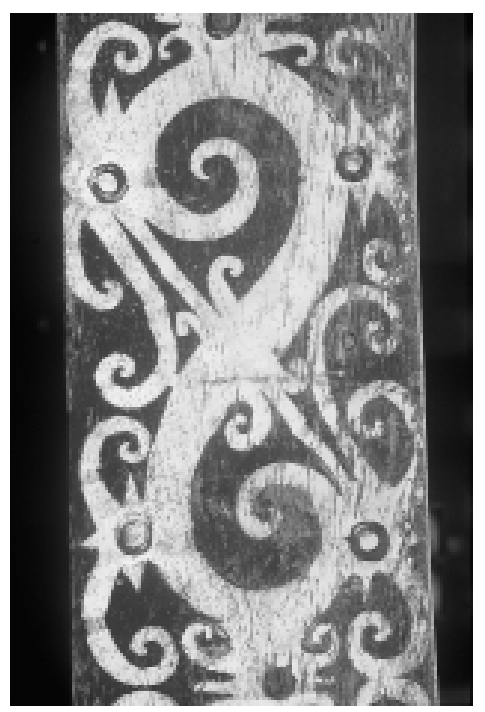

(b)

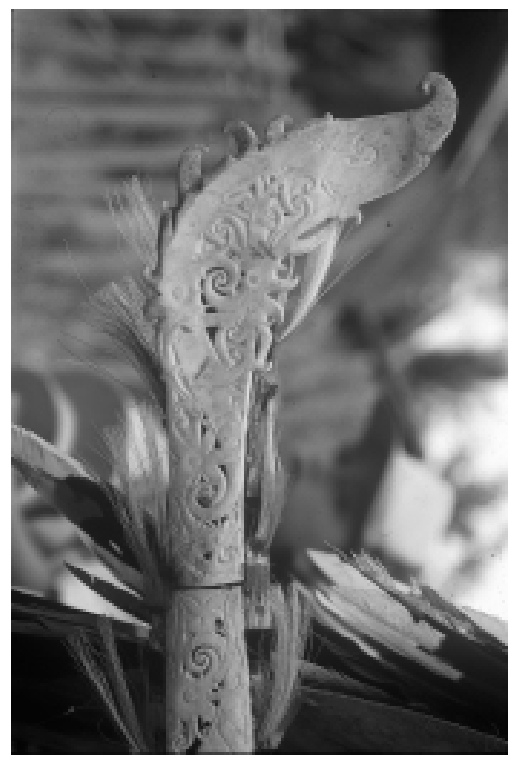


Gigi binatang seperti kule lenjau (Pardofelis nebulosa), kule bilung (Pardofelis marmorata), buang (Helartos malayanus), dan ba'bui (Sus barbatus) dipakai untuk hiasan ba'(Leppo' Ma'ut=gendongan bayi) yaitu alat untuk menggendong bayi. Di bagian luar dari bening ini gigi dari binatang ini digantung sebagai hiasan. Orang tidak boleh sembarang menggunakan gigi binatang tersebut Hanya paren bio' (bangsawan besar) yang boleh memakai gigi kule lenjau yaitu paren dari Leppo' Kulit dan Leppo' Jalan. Sedangkan paren dari leppo'yang lain, mereka tidak berani memakainya untuk hiasan di gendongan bayi. Kalau paren dari leppo'yang lain, mereka hanya boleh pakai gigi kule bilung saja. Walaupun mereka punya gigi kule lenjau biasanya mereka hanya memakai kalung pada waktu tahun baru atau pesta saja. Orang panyen tidak boleh memakai gigi kule. Orang panyen hanya boleh pakai gigi buang dan ba'bui yaitu satu baris saja sebanyak enam buah tidak boleh lebih, diletakkan di bawah. Kalau orang paren boleh memakai sampai empat baris sebanyak 24 buah. Kalau mereka sembarangan memakai gigi kule, mereka takut kena parip (sial) yaitu anak sakit-sakitan atau anak bisa meninggal. Hal ini sangat mereka percayai, sebab dulu masyarakat pernah membuktikan bahwa ada orang yang sembarangan memakai gigi ini sebagai hiasan gendongan bayi, lalu anaknya meninggal berturut-turut. Setelah gigi kule ini dilepas baru anak berikutnya dapat bertahan hidup sampai dewasa.

Ada kecenderungan sekarang pemakaian gigi-gigi yang berasal dari alam mulai berkurang karena sulit mendapatkan gigi kule lenjau, kule bilung, dan gigi buang. Sebagai penggantinya digunakan gigi palsu yang berasal dari pabrik dan sudah banyak diperjualbelikan. Oleh karena mudah mendapatkannya maka orang semakin bebas saja membeli dan memakainya. Di samping itu melemahnya adat menyebabkan orang juga secara sembarangan menggunakan simbolsimbol ini sekarang. Mereka mulai bercampur memakai simbol ini, alasannya karena mereka sudah masuk agama Kristen. Walaupun mereka sekarang mampu membeli gigi yang asli peninggalan dari orang paren tetapi gigi tersebut sulit dicari karena jumlahnya sedikit. Selain itu binatangnya sekarang semakin langka. Mereka membeli gigi yang palsu dan membuat gambar kabuk, baya' atau ila'dengan manik-manik pada alat gendongan bayinya, namun demikian mereka 
yang tahu aturan adat dan parip (akibat yang menyebabkan sial) tetap tidak berani menggunakan gigi yang asli.

Pemakaian simbol-simbol ini sekarang semakin bercampur, namun tetap dapat dibedakan antara paren dengan panyen. Mereka yang memakai gendongan bayi dengan gambar kabuk atau ila'tetapi payungnya dari daun sang atau sa'ung sang yang dihiasi dengan kain dari toko (payung kain dari toko), maka artinya mereka adalah panyen. Apabila ada orang yang memakai simbol dari kabuk atau ila' dan memakai saung seling (topi peninggalan nenek moyang dari dulu) atau saung eko (topi yang berhiasan bulu temengang) tetapi tidak memakai gigi asli atau hanya gigi buang atau gigi kule bilung, artinya ia adalah orang panyen tiga. Sedangkan mereka yang memakai simbol kabuk, baya', atau ila'memakai gigi asli dari kule lenjau dan dia juga memakai saung seling atau saung eko, maka mereka adalah paren bio'. Orang paren bio' juga boleh memakai gigi binatang yang lain seperti kule bilung atau buang.

\section{Nama-nama Orang Dayak Diambil Dari Nama Binatang dan Tumbuhan Berdasarkan Status Sosial}

Selain simbol status sosial yang telah disebutkan di atas nama-nama orang Dayak juga ada yang diambil dari nama binatang dan tumbuhan. Contohnya ${ }^{18}$ : Kule (nama umum dari macan), Bilung (macan kecil), Lenjau (macan yang besar), Baya' (buaya), Ngang (burung yang paling besar), Ba'un, (burung teba'un), Tu'ban (ekor burung teba'un yang sudah dipakai sebagai hiasan topi), Kirip (sayap burung tebaun yang dipakai hiasan menari), Punai (sejenis burung), Merang (sejenis kayu yang keras), Ulin (sejenis kayu yang paling keras), Suling (sejenis kayu untuk pewarna), Jangin (nama jenis tumbuhan), Adau (sejenis tumbuhan untuk kayu bangunan), Lirang (tumbuhan obat), Limbang (tumbuhan obat), Pai (tumbuhan sejenis rengas), Ipo' (tumbuhan racun), Salo' (tumbuhan racun), Sapuk (bunga), Peu (bunga mekar), Ulem (buah sejenis terong pipit), Njuk (sejenis lengkuas), $\boldsymbol{P i n g}$ (rumput), $\boldsymbol{U d a n g}$ (sejenis ikan), kulat (sejenis jamur), dan lain-lain. 
Nama paren (bangsawan) menggunakan nama untuk lakilaki: Kule, Lenjau, Bilung, Baya', Ngang, dan Merang, dan untuk perempuan: Ba'un, Kirip, Suling, Sapuk, dan lain-lain. Untuk nama panyen (biasa) digunakan nama untuklaki-laki: Njuk, Ipo', Salo; dan untuk perempuan: Ulem, Limbang, Udang, Ping, Kulat, dan lain-lain. Nama-nama lainnya yang bukan dari binatang atau tumbuhan untuk nama paren laki-laki adalah Lawai, dan Ingan; dan untuk perempuan adalah: Bulan, Bungan, Kilet, dan Lambang. Nama panyen yang lain, untuk laki-laki adalah Dungau, Ungau, Irang, Bat, Bong, Dan, dan lain-lain. Nama orang panyen yang lain untuk perempuan adalah Bun, Uding, Usun, Long, dan lain-lain. Nama orang paren dan orang panyen tidak boleh dicampur. Orang tidak boleh sembarang membuat nama anaknya, namun harus tergantung golongannya. Orang percaya apabila orang sembarangan membuat nama anaknya, maka anaknya akan sakit-sakitan seumur hidupnya.

\section{HUTAN SEBAGAI TEMPAT BERTEDUH DAN MENCARI HIBURAN}

Di hutan orang Dayak merasa tenang dan nyaman serta merasa lebih dekat dengan Tuhan. Di dalam hutan pikiran mereka terhibur mendengar suara alam, kicau burung dan gemercik sungai yang melantunkan sabda alam. Di kala mereka merasa jenuh dengan pekerjaan di ladang maupun di rumah maka mereka masuk ke hutan untuk mencari hiburan. Kebiasaan ini sering kita dengar lewat dialog, misalnya ketika bertemu dengan seseorang atau sekelompok orang yang sedang berangkat ke hutan, lalu kita bertanya: "ke mana?", sering mereka menjawab: "cari hiburan dulu"; "di mana ?", dijawab: "ka' daya” (di hulu sungai, maksudnya di hutan), dan sebagainya. 


\section{Bab 4 \\ Pengaturan Hutan Berdasarkan Hukum Adat Secara Lokal}

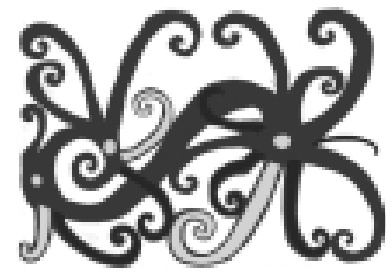

Pemanfaatan hutan yang dijelaskan di atas diatur sejak turun-temurun dengan hukum adat. Hukum adat untuk mengatur pengelolaan hutan mencerminkan ketergantungan masyarakat pada hutan, misalnya adalah tana' ulen. Hukum adat yang berlaku dari dulu merupakan hukum adat yang tidak tertulis. Sedangkan hukum negara merupakan hukum tertulis. Kadang-kadang hukum adat dan hukum negara saling mengisi, tetapi kadang-kadang terjadi konflik juga, misalnya tentang penggunaan hutan, batas taman nasional yang dibuat berdasarkan hukum negara lain dan tidak memperhatikan batas hutan adat yang ditentukan masyarakat secara turun temurun. Hukum adat dan hukum negara seharusnya saling mengisi ${ }^{20}$, yakni apabila hukum adat belum mengatur, maka hukum negara yang mengaturnya. Sebaliknya apabila dalam hukum negara tidak ada, maka hukum adat yang mengaturnya. Apabila kedua-duanya ada pengaturannya maka yang diutamakan lebih dulu adalah pengaturan hukum adat, karena hukum adatlah yang lebih sesuai berdasarkan kondisi, situasi, dan pengalaman sejarahnya. 


\section{A. SIFAT HUKUM ADAT YANG TIDAK STATIS DIBUAT DENGAN SISTEM PENYESUAIAN DENGAN KEADAAN BARU}

Orang pada umumnya mengetahui adanya hukum adat secara lisan. Hukum adat mulai ditulis di Wilayah Adat Hulu Sungai Bahau oleh kepala-kepala adat sekitar tahun 1993-94. Sifat hukum adat yang tidak statis dibuat dengan sistem penyesuaian dengan keadaan baru. Sebagai contoh, peraturan adat yang dibuat di hulu Sungai Bahau selalu ditinjau kembali setiap tahunnya pada waktu Pesta Panen Gabungan dan Musyawarah Adat Besar Hulu Sungai Bahau. Aturan yang lama disempurnakan dengan cara menambah atau mengurangi pasal-pasal yang telah ada, sehingga selalu dapat menyesuaikan dengan perkembangan jaman.

Hukum adat diatur terutama oleh kepala adat di desa dan kepala adat besar. Tokoh masyarakat juga dilibatkan untuk mengambil keputusan bersama dalam desa maupun di wilayah adat tersebut. Kalau mengambil keputusan dalam desa, urusan pemerintahan, dan urusan luar secara umum didiskusikan bersama dengan kepala desa. Sedangkan kalau yang terkait dengan hutan, denda, dan urusan keluarga, ketua adat dan kepala adat besar yang bertanggung jawab terhadap keputusan itu.

Peraturan adat dalam waktu lima tahun terakhir (1993-98) telah banyak mengalami perubahan dan pembaruan, namun pasalpasal yang masih relevan masih dipakai. Contohnya, Keputusan Musyawarah Kepala-Kepala Desa dan Kepala Adat Hulu Bahau di Long Tebulo Tahun 1996 masih mengacu pada keputusan yang dibuat di Apau Ping pada tahun 1994, terutama Pasal X mengenai watas ladang ${ }^{21}$, dan Pasal XI mengenai watas desa $^{22}$, yang isinya mengenai pengaturan hasil hutan, daerah perladangan, persawahan, kayu yang dapat dimanfaatkan sebagai bahan bangunan, perahu, dan lain-lain. Keterlibatan WWF Kayan Mentarang memberikan pengaruh penting terhadap masukan-masukan dalam hukum adat pada tahun 1996, yang memiliki nilai bagi konservasi dan kesejahteraan masyarakat di sekitarnya. Dialog antara masyarakat terutama pemuka adat dan desa dengan staf WWF Kayan Mentarang mengenai dampak negatif dari 
pemanenan hasil hutan secara berlebihan, dan bahayanya penggunaan racun dan strum telah membuahkan hasil, yang kemudian dapat dimuat dalam hukum adat secara tertulis.

\section{B. HUKUM ADAT TERHADAP HUTAN}

Masyarakat telah menyadari ketergantungannya dengan hutan, maka setiap desa memiliki aturan pemanfaatan dan pengelolaan hutan. Aturan ini pada dasarnya adalah untuk mencegah konflik mengenai berbagai kepentingan dalam masyarakat. Ada aturan untuk pemanfaatan binatang, kayu-kayu, dan batas ladang, serta kepemilikan jekkau (bekas-bekas ladang).

Aturan adat untuk pemanfaatan binatang yang sudah lama diatur adalah menjaga babi berenang (ba'bui satung). Bila musim babi berenang tidak boleh menjaga jalannya di darat. Bila menangkap babi berenang tidak boleh menembak dengan senapan, hanya boleh menggunakan bujak dan parang. Tidak diperkenankan menangkap binatang dengan menggunakan ranjau (belatik) yang berbahaya. Tidak boleh menangkap ikan menggunakan strum. Belakangan ini mulai diatur pengambilan landak (settung) untuk keperluan batu settung untuk dijual karena harganya mahal. Selain itu ada juga larangan membunuh banteng (Bos javanicus), mengambil tanduk payau, dan membunuh beruang sembarangan, kecuali binatang tersebut merusak dan melawan orang yang sedang di hutan.

Pemanfaatan kayu-kayu untuk bangunan masih banyak yang belum dicantumkan dalam hukum adat tertulis. Namun umumnya ada aturan tidak tertulis yang diketahui. Contohnya: kayu-kayu yang berada di dalam hutan, apabila ada orang yang ingin memanfaatkannya di kemudian hari sebagai bahan bangunan, maka kayu itu diberi tanda pada batangnya. Biasanya setinggi dada, dengan simbol silung kelunan (muka manusia). Artinya orang lain tidak boleh mengambil pohon itu lagi selain yang memberi tanda pertama kali. Selain itu ada juga dengan cara mesip, yaitu menandai suatu pohon kayu dengan sebatang tongkat yang disisipi daun, yang ujungnya diarahkan 
menunjuk batang kayu tersebut. Ada juga yang memberi tanda di batang kayu tersebut dengan cara melukai batangnya kemudian menyisipkan daun-daun di situ. Pada perkembangan sekarang ada juga tanda yang dibuat dengan menulis nama mereka sendiri, sehingga orang lain mengetahui siapa pemilik kayu tersebut. Memberi tanda ini disebut mulen (melarang).

Untuk kayu-kayu gaharu masyarakat lokal yang ada di sekitar TN Kayan Mentarang telah memiliki sistem sendiri. Secara lisan, ada pemahaman bahwa kayu gaharu hanya boleh ditebang kalau ada aing (isi yang berwarna hitam dan harum), jika tidak ada aing tidak boleh ditebang, dibiarkan sampai ada aingnya. Alasan ini juga disebabkan untuk menebang pohon gaharu yang tidak ada isi hanya membuang tenaga percuma dan makan waktu. Alasan lain adalah masih bisa ditebang nanti kalau sudah ada isi. Biasa juga kalau pohon ditebuk (dilukai dengan parang), lama-lama ada isi aingnya.

Terhadap kepemilikan pohon-pohon buah yang ditanam diatur berdasarkan aturan lisan yang secara turun-temurun. Siapa yang menanam maka dia yang punya pohon tersebut. Sebagai contoh kasus, ada pohon buah di halaman rumah seseorang yang tinggal di hulu kampung. Orang yang tinggal di dekat pohon itu tidak boleh memetik buahnya, karena ternyata pohon buah ini dimiliki oleh orang yang bermukim jauh di hilir. Hal ini ternyata berkaitan dengan sejarah perpindahan penduduk di tempat itu. Orang yang pindah pertama kali ke sana hanya beberapa keluarga saja. Keluarga ini membuat kebun dengan menanam tanaman buah-buahan di lokasi tersebut. Kemudian ada orang lain yang baru pindah ke kampung itu, mereka minta ijin kepada yang punya kebun di situ untuk membangun rumah di sana. Apabila yang punya kebun itu memberi ijin, mereka boleh membangun rumah di sana, tetapi kebunnya masih milik orang yang menanamnya. Kalau musim buah, yang boleh memetik buahnya hanya orang yang punya, yaitu orang yang menanamnya, walaupun rumahnya jauh dari situ. Sedangkan orang yang tinggal di dekatnya tidak boleh memetiknya, apabila mereka memetik dianggap mencuri dan itu didenda. Orang yang tinggal di dekatnya boleh memungut 
buah yang jatuh, dan kalau waktunya yang punya sudah mulai panen biasanya orang yang tinggal di situ juga diberi bagian.

Aturan lain adalah mengenai larangan membakar hutan dan padang alang-alang yang telah dicantumkan dalam hukum adat, khususnya Wilayah Adat Besar Hulu Bahau, dalam Pasal IX sebagai berikut: Ayat a. Membakar hutan dengan sengaja (bukan karena harus dibakar dengan alasan perladangan) yang akibatnya merugikan orang lain dikenai denda berupa satu buah anggung jangin (gong) untuk orang yang dirugikan. Ayat b. Membakar hutan/lalang di daerah yang dapat dimanfaatkan untuk berladang sekalipun tidak mengakibatkan kerugian pada anggota masyarakat itu sendiri, misalnya pohon-pohon buah, kebun tidak ada yang terbakar tetapi merugikan masyarakat secara umum karena tanah menjadi tandus, maka tetap didenda satu buah anggung jangin. Ayat c. Kesimpulannya jika pelanggaran itu mencakup Pasal IX ayat a dan b, maka denda yang dituntut menjadi dua kali lipat, yakni dua buah anggung jangin, 1 buah diserahkan kepada pihak yang dirugikan, dan satu buah anggung dimasukkan ke dalam kas desa/adat.

Aturan tentang pengusaha hasil hutan telah dicantumkan pada Pasal XXV yang isinya sebagai berikut: Ayat a. Pengusaha-pengusaha hasil hutan dari luar daerah Hulu Bahau (sembilan desa) tidak diperkenankan memungut hasil hutan (gaharu, rotan, kayu manis, damar) secara langsung, tetapi boleh membeli dari masyarakat sebagai penampung hasil hutan dengan surat ijin dari Bupati, dan melalui Camat agar tidak terjadi kesalah ahaman antara pengusaha dengan masyarakat desa Hulu Bahau. Ayat b. Pengusaha hasil hutan asal putera daerah yang sudah pindah ke daerah lain tidak diperkenankan menjalankan usaha hasil hutan dengan jumlah banyak terkecuali bergabung dengan masyarakat dan diberi waktu terbatas, (satu sampai dengan tiga orang). Ayat c. Namun asal putera daerah jika rombongannya lebih dari tiga orang tidak diberi ijin masuk di hutan untuk mengusahakan kayu gaharu karena tamu-tamu dari luar daerah tidak memelihara kayu gaharu/rotan dll. yang ada di hutan malahan merusak habis-habisan kayu gaharu yang belum pada waktunya 
ditebang. Ayat d. Pengusaha hasil hutan yang masuk langsung di dalam hutan dan di dalam wilayah desa Hulu Bahau tanpa ijin dikenai denda satu orang Rp. 250.000 dimasukkan ke dalam kas adat. Ayat e. Pengusaha hasil hutan yang melalui ijin dan terpaksa karena kebijaksanaan, (paling banyak satu rombongan lima orang) harus menyumbang uang sebesar Rp. 500.000 terlebih dulu kepada desadesa yang bersangkutan, barulah boleh masuk untuk berusaha dan batas waktu dapat dirundingkan dengan kepala desanya.

Untuk pengaturan batas ladang dan jekkau dibuat kesepakatan sewaktu orang mulai membuka hutan rimba pertama kali. Sebelum mulai membuka hutan diadakan rapat di desa yang dihadiri oleh seluruh masyarakat. Setelah lokasi ditentukan dan disepakati bersama maka besoknya diberi tanda dan dibuat batasbatas (biasanya pohon-pohon) yang harus dikerjakan masing-masing. Menebas ladang bisa dilakukan dengan senguyun (pertukaran hari tenaga kerja), ada juga yang dikerjakan sendiri. Aturan mengenai batas ladang telah dicantumkan dalam hukum adat tertulis, yaitu Pasal X (lihat catatan kaki no. 21). Sedangkan pengaturan mengenai jekkau (bekas ladang) belum dimasukkan dalam hukum tertulis. Melalui hukum adat lisan, misalnya orang tertentu ingin memanfaatkan jekkau milik orang lain, mereka boleh pinjam untuk beberapa tahun tetapi harus minta ijin. Jekkau adalah hak milik orang yang membuat ladang pertama kali di tempat tersebut dengan membuka hutan rimba.

\section{TANA'ULENDI HULU BAHAU}

\section{Konsep Tana'Ulen}

Salah satu unsur penting dalam hukum adat berkaitan dengan pemanfaatan dan pengelolaan hutan adalah konsep tana' ulen. Tana' ulen atau sungai ulen ${ }^{2}$ adalah suatu kawasan hutan rimba yang dilindungi secara adat. Wilayah tana' ulen meliputi satu sungai atau beberapa sungai kecil mulai dari muaranya sampai ke ujung-ujung 
anak sungai di titik mata airnya. Batas-batas tana' ulen meliputi punggung-punggung gunung di mana sungai tersebut mengalir.

Di dalam wilayah tana' ulen orang dilarang menebang pohon, membakar hutan, membuat ladang, dan kegiatan yang menimbulkan kerusakan hutan. Pengambilan hasil hutan di dalam tana' ulen diatur hanya untuk memanfaatkan beberapa jenis hasil hutan tertentu saja. Hasil hutan yang boleh diambil dari tana' ulen antara lain: gaharu, rotan, kayu manis, buah-buahan, ikan, dan binatang. Tana' ulen hanya dimanfaatkan pada waktu-waktu tertentu untuk kepentingan umum apabila ada kegiatan di desa. Pengambilan hasil hutan dalam wilayah tana' ulen ditentukan berdasarkan hasil musyawarah bersama seluruh masyarakat atau pemuka-pemuka desa yang meliputi seluruh aparat desa antara lain kepala desa, kepala adat di desa, dan kepala adat besar.

Pengaturan cara pemanenan hasil hutan di dalam tana' ulen apabila ada kesepakatan untuk memanennya, orang tidak diperkenankan mengambil secara sembarangan dan merusak hasil hutan yang ada di dalamnya. Contoh untuk pengambilan rotan, tidak boleh memotong batang yang masih muda yang panjangnya belum cukup untuk dapat dimanfaatkan.

Pengambilan untuk kepentingan pribadi hanya boleh apabila diberi ijin berdasarkan keputusan kepala adat hasil musyawarah. Orang yang masuk mengambil hasil hutan dikenai cukai per orang. Jumlah cukai ini bisa kecil, misalnya Rp. 20.000 atau besar, Rp. 200.000, berdasarkan nilai hasilnya, lama bekerja dan ditetapkan berdasarkan peraturan. Cukainya biasanya dibayar kepada kepala adat atau kepala desa dan seharusnya, dipakai untuk kas adat. Peraturan untuk orang yang berasal dari penduduk setempat (orang asli) berbeda dengan peraturan untuk orang pendatang (= kelunan alo'yaitu orang yang berasal dari luar daerah). Umumnya peraturan yang ditetapkan untuk penduduk asli setempat lebih longgar, kadang-kadang masih boleh mengambil untuk keperluan sehari-hari apabila tidak ada hasil di tempat lain. Sedangkan orang dari luar sama sekali tidak diperbolehkan. 


\section{Asal Usul Konsep Tana' Ulen}

Asal usul tana' ulen semula hanya dimiliki oleh para bangsawan (paren) di Long Alango, Long Uli, dan Long Pujungan. Tana' ulen Long Alango semula dimiliki oleh Kepala Adat Besar Hulu Bahau Apui Njau sekitar tahun 1925 sampai 1967 (sejak jaman penjajahan Belanda sampai Indonesia merdeka). Tana' ulen yang diklaim meliputi daerah aliran sungai (DAS) Nggeng. Tana' ulen desa Long Uli meliputi wilayah Sungai Lutung. Sedangkan tana'ulen desa Long Pujungan meliputi Sungai Ahan.

Sewaktu Apui Njau menjadi Kepala Adat Besar Hulu Bahau, orang dilarang memasuki tana' ulen di Sungai Nggeng, konon muara sungai dijaga ketat. Siapa yang berani melewati batas yang telah diberi tanda maka orang tersebut disumpit. Apui Njau sangat ahli meniup sumpit. Menurut cerita dari mulut ke mulut, beliau mengeluarkan pernyataan, "Siapa yang berani masuk ke dalam wilayah tana' ulen, awas!" Sehingga tidak ada orang yang berani datang ke sana pada waktu itu. Setelah beliau wafat pada tahun 1967, penjagaan tana' ulen mulai cenderung berkurang, sampai akhirnya tana' ulen ditetapkan menjadi tana' ulen desa.

Pada tahun 1980 pemerintah Indonesia menetapkan wilayah yang meliputi hulu-hulu Sungai Kayan sampai Sungai Mentarang sebagai cagar alam berdasarkan SK Menteri Pertanian No. 847/Kpts/ Um/II/1980, seluas 1.360 .500 ha. Penunjukan kawasan cagar alam ini sebagai realisasi atas kecaman dunia internasional terhadap pemerintah Indonesia bahwa Indonesia merupakan negara perusak hutan tropis melalui kegiatan $\mathrm{HPH}$, perkebunan, transmigrasi, dan konversi untuk berbagai kepentingan. Setelah penetapan status cagar alam tersebut, kemudian pada tahun-tahun berikutnya diadakan beberapa survei untuk menggali informasi. Sekitar tahun 1990 Ditjen PHPA bekerjasama dengan WWF Indonesia dan Lembaga Ilmu Pengetahuan Indonesia (LIPI) melakukan kegiatan untuk penyusunan rencana pengelolaan kawasan Kayan Mentarang. WWF dan LIPI melakukan survei di dalam Cagar Alam Kayan Mentarang. Hasil dari survei tersebut menunjukkan bahwa keberadaan masyarakat Dayak 
perlu diperhatikan dan ketergantungannya terhadap hutan sangat tinggi, dan apalagi ada keterkaitan budaya masyarakat Dayak terhadap hutan. Hasil yang penting lainnya adalah bahwa masyarakat Dayak telah memiliki aturan untuk mengelola hutan secara lokal. Ada buktibukti yang menunjukkan bahwa orang Dayak telah mengelola hutan selama berabad-abad namun tidak menimbulkan kerusakan terhadap hutan. Oleh sebab itu pengelolaan hutan dengan sistem adat yang berkaitan dengan perlindungan hutan dan konservasi diangkat untuk dijadikan sistem pengelolaan secara lokal. Maka pada waktu itu, sekitar tahun 1992 sampai 1994, WWF dan Camat Pujungan menyarankan agar setiap desa memiliki tana' ulen. Sehingga setiap desa kemudian mengklaim wilayah tana' ulen masing-masing dengan arti lebih luas daripada yang aslinya.

Pada tahun 1994 status cagar alam diusulkan untuk dirubah menjadi taman nasional, berdasarkan hasil-hasil survei oleh tim dari Instansi Pusat, Pemda Tingkat I dan II, WWF, dan PT. Giri Ekawana, yang menyimpulkan bahwa keberadaan masyarakat di sekitar cagar alam penting diperhatikan, maka diusulkan agar status cagar alam dirubah menjadi taman nasional. Akhirnya pada tanggal 7 Oktober 1996 Cagar Alam Kayan Mentarang dirubah status menjadi Taman Nasional Kayan Mentarang berdasarkan SK Menteri Kehutanan No. 631/Kpts-II/1996. Dengan status taman nasional, masyarakat di dalam dan di sekitar wilayahnya bisa tetap tinggal disana dan menggunakan sumber daya alam yang tertentu, sesuai peraturannya. Kalau masih cagar alam, wilayahnya tidak boleh digunakan sama sekali oleh orang setempat.

Untuk melindungi kawasan TN Kayan Mentarang dan hutan bagi kepentingan masyarakat Dayak terhadap ancaman kerusakan dari luar, maka hal ini dilakukan dengan mempertahankan dan memperkuat status hukum wilayah hutan di daerah perbatasan taman nasional. Wilayah hutan di daerah perbatasan ini sebagian besar adalah hutan adat dan wilayah desa-desa yang berada di sekitar taman nasional. Kemudian bersama-sama dengan WWF dilakukan pemetaan wilayah desa secara partisipatif dari tahun 1993 sampai 1998. Pemetaan desa partisipatif bertujuan untuk mengetahui batas-batas 
desa dan wilayah hutan (dan sumber lain) yang mau dilindungi oleh masyarakat, seperti konsep tana'ulen yang asli. Semua desa di Sungai Bahau yang ada kaitan dengan TN Kayan Mentarang sudah dipetakan.

Menurut masyarakat, untuk menjaga keadaan hutan dan melindungi hak masyarakat, wilayah desa sangat penting diketahui dan dipertahankan untuk mencegah konflik yang timbul baik dari dalam wilayah desa sendiri maupun dari luar wilayah desa. Pentingnya mengetahui wilayah desa juga berperanan bagi masyarakat untuk mengatur wilayah desanya terhadap pemanfaatan lahan. Para kepala desa maupun kepala adat juga berperan penting untuk mengatur warganya bila sudah memiliki wilayah desa yang jelas. Bagi kepentingan pemerintahan hal itu dapat mempermudah dalam pengaturan tata ruang wilayah terhadap penggunaan lahan dalam berbagai bidang. Di bawah ini diuraikan masalah-masalah yang dapat diatasi dengan adanya wilayah desa.

\section{Mencegah Konflik dari dalam Wilayah Desa dan Wilayah Adat}

Konflik di desa dapat timbul dari dalam, yaitu dari warga masyarakat sendiri terutama sebagai akibat pemanfaatan sumberdaya di dalam wilayah desa sendiri. Pemanfaatan sumberdaya hutan telah diatur dalam hukum adat, khususnya Adat Besar Hulu Bahau, Pasal XI, dan menunjuk pada keputusan kepala-kepala desa Hulu Bahau pada surat nomor 01/K.A.B./II/1994 tertanggal 3 Februari 1994 di Apau Ping. Pengambilan hasil hutan antar desa tidak harus persis dalam garis perbatasan desa. Khusus untuk sembilan desa di Hulu Bahau, boleh melewati asalkan ada ijin dari kepala-kepala desa bersangkutan dan berdasarkan kekeluargaan.

Pemakaian lahan dalam wilayah desa khususnya batas ladang, diatur dalam Pasal X, Ayat a. yang menyatakan: terjadi pelanggaran atas batas ladang di antara masyarakat itu sendiri yang tadinya diberi tanda dan disepakati oleh kedua belah pihak yang berbatasan ladang pada waktu menebas hingga pada waktu menebang. Ternyata pada 
waktu menugal (menanam padi) karena sudah bersih satu pihak menggeser atau merubah tanda tersebut, perbuatan ini dikenai denda satu buah parang biasa, dan diserahkan kepada yang menuntut. Ayat b. menyatakan: terjadi perebutan atau keributan mengenai batas perladangan antara desa langsung ditangani oleh Kepala Adat Besar Hulu Bahau dengan rasa kekeluargaan atau pertimbanganpertimbangan dan kebijaksanaan bersama dari kedua hakim adat yang bersangkutan, sesuai dengan hasil musyawarah para kades Hulu Bahau di Apau Ping (tahun 1994).

\section{Mencegah Konflik dari Luar}

Ancaman terhadap perusakan hutan secara besar-besaran yang berasal dari luar wilayah desa, misalnya HPH dengan menggunakan peralatan modern dapat merusakkan ribuan hektar sumberdaya hutan yang bermanfaat bagi masyarakat dan mengganggu sungai dalam waktu singkat. Konversi hutan untuk berbagai kepentingan dengan membuka areal hutan yang luas juga dapat terjadi dalam waktu yang tidak terlalu lama. Para pencari gaharu dari luar daerah yang terdiri dari rombongan besar dapat merusakkan sistem pengelolaan hutan yang diterapkan oleh masyarakat, sehingga akhirnya dapat mengancam kelestarian pemanfaatan sumberdaya gaharu dan sumberdaya lain yang turut diambil. Sistem pemanfaatan pencari gaharu dari luar yang tanpa memperhatikan pelestarian, di mana mereka langsung menebang pohon gaharu walaupun tidak ada isinya dapat mengancam sumber pendapatan masyarakat setempat. Demikian pula dengan binatang buruan yang ditangkap menjadi semakin banyak jumlahnya sehingga pada akhirnya menjadi pesaing yang dapat mengurangi hasil tangkapan penduduk setempat. Akhirnya jika tidak ada pembatasan, pencari gaharu dari luar yang masuk dalam jumlah besar dapat menimbulkan konflik dengan masyarakat.

Dalam aturan adat yang telah ditetapkan berdasarkan Keputusan Musyawarah Kepala-Kepala Desa dan Kepala Adat Hulu Bahau pada waktu Pesta Panen Gabungan di Desa Long Tebulo tahun 
1996, telah diatur dalam Pasal XXV (dapat dilihat pada bagian Hukum Adat terhadap Hutan dalam tulisan ini) yang intinya membatasi pengusaha untuk memungut hasil hutan seperti: gaharu, rotan, kayu manis, dan damar. Pengusaha-pengusaha hasil hutan dari luar daerah tidak diperkenankan memungut hasil hutan secara langsung, tetapi boleh membeli dari masyarakat dengan ijin dari Bupati. Pengusaha hasil hutan asal putra daerah yang sudah pindah ke tempat lain, diperkenankan dalam waktu terbatas untuk satu sampai tiga orang dan bergabung dengan masyarakat setempat. Pengusaha hasil hutan asal putera daerah yang anggotanya lebih dari tiga orang tidak diberi ijin masuk ke hutan. Pengusaha hasil hutan yang masuk tanpa ijin, didenda Rp. 500.000 per orang, uangnya masuk kas adat. Pengusaha hasil hutan yang melalui ijin hanya diperkenankan masuk ke hutan setelah menyerahkan sumbangan ke kas adat sebesar Rp. 500.000 dan maksimum lima orang dalam satu rombongan dengan batas waktu yang dapat dirundingkan dengan kepala desanya. Dengan adanya pengaturan hutan berdasarkan hukum adat secara lokal dan tana' ulen maka konflik dapat dicegah.

\section{SANKSI-SANKSI TERHADAP PELANGGARAN HUKUM ADAT}

Bagi pelanggaran yang dilakukan terhadap peraturan yang dibuat di atas, dikenakan sanksi-sanksi berupa denda dengan barang atau setara nilai uang yang telah ditetapkan. Adapun peraturan yang belum tercantum atau adanya kemungkinan muncul permasalahan baru yang belum termuat dalam hukum adat tersebut akan dilakukan tindakan berdasarkan hasil musyawarah adat secara kekeluargaan.

Denda pelanggaran yang ditetapkan dan penyetaraan nilai uang berdasarkan Keputusan Musyawarah Besar Kepala-Kepala Desa dan Kepala Adat Hulu Bahau di Long Tebulo pada tahun 1996, sebagai berikut: 
a. Tempayan busi pu'un (pelayung wing)

Rp. 500.000

b. Tempayan busi kabuk

Rp. 400.000

c. Tempayan busi abai

Rp. 300.000

d. Tempayan busi wai

Rp. 250.000

e. Tempayan $\boldsymbol{b e} \mathbf{l a}$ '

Rp. 200.000

f. Anggung pu'un

Rp. 500.000

g. Anggung jangin

Rp. 100.000

h. Anggung batu

Rp. 50.000

i. Anggung jilen

Rp. 200.000

j. Parang berukir dan rambut

Rp. 200.000

k. Parang biasa lengkap

Rp. 30.000

Sumber: Keputusan Musyawarah Kepala-Kepala Desa dan Kepala Adat Hulu Bahau di Long Tebulo Tahun 1996.

\section{E. PENGAKUAN HUTAN ADAT BERDASARKAN UNDANG-UNDANG NEGARA}

Pada bulan September 1999 telah berhasil dibuat Rancangan UndangUndang Republik Indonesia tentang Kehutanan, di mana dalam Rancangan Undang-Undang ini telah disebutkan bahwa pemerintah mengakui hutan adat dan memperhatikan hak masyarakat hukum adat. Pasal 1 ayat (6) menyatakan sebagai berikut: "Hutan adat adalah hutan negara yang berada dalam wilayah masyarakat hukum adat". Selanjutnya dijelaskan pada Pasal 4 ayat (3) yang bunyinya sebagai berikut: "Penguasaan hutan oleh negara tetap memperhatikan hak masyarakat hukum adat, sepanjang kenyataannya masih ada dan diakui keberadaannya, serta tidak bertentangan dengan kepentingan nasional".

Pasal 5 ayat (2): "Hutan negara sebagaimana dimaksud pada ayat (1) huruf a, dapat berupa hutan adat". Ayat (3): "Pemerintah menetapkan status hutan sebagaimana dimaksud pada ayat (1) dan ayat (2); dan hutan adat ditetapkan sepanjang menurut kenyataannya masyarakat yang bersangkutan masih ada dan diakui keberadaannya". Ayat (4): "Apabila dalam perkembangannya masyarakat hukum adat yang bersangkutan tidak ada lagi, maka hak pengelolaan hutan adat kembali kepada pemerintah". 
Pengelolaan hutan berdasarkan hukum adat dijelaskan pada Pasal 67 yang bunyinya sebagai berikut: ayat (1) "Masyarakat hukum adat sepanjang menurut kenyataannya masih ada dan diakui keberadaannya berhak: a. melakukan pemungutan hasil hutan untuk pemenuhan kebutuhan hidup sehari-hari masyarakat adat yang bersangkutan; b. melakukan kegiatan pengelolaan hutan berdasarkan hukum adatyang berlaku dan tidak bertentangan dengan undang-undang; dan c. mendapatkan pemberdayaan dalam rangka meningkatkan kesejahteraan. Ayat (2) "Pengukuhan keberadaan dan hapusnya masyarakat bukum adat sebagaimana dimaksud pada ayat (1) ditetapkan dengan Peraturan Daerah". Ayat (3) Ketentuan lebih lanjut sebagaimana dimaksud pada ayat (1) dan ayat (2) diatur dengan Peraturan Pemerintah.

Pasal 68 ayat (3) Masyarakat di dalam dan di sekitar hutan berhak memperoleh kompensasi karena hilangnya akses dengan hutan sekitarnya sebagai lapangan kerja untuk memenuhi kebutuhan hidupnya akibatpenetapan kawasan hutan, sesuai dengan peraturan perundang-undangan yang berlaku. Ayat (4) Setiap orang berhak memperoleh kompensasi karena hilangnya hak atas tanah miliknya sebagai akibat dari adanya penetapan kawasan hutan sesuai dengan ketentuan peraturan perundang-undangan yang berlaku.

Selain itu pemerintah juga memberikan hak terhadap hutan untuk tujuan khusus. Pasal 8 ayat 1 bunyinya: "Pemerintah dapat menetapkan kawasan butan tertentu untuk tujuan khusus", yaitu untuk kepentingan umum antara lain disebutkan pada ayat 2 huruf c. religi dan budaya". Kemudian dijelaskan dalam Pasal 34 yang bunyinya: "Pengelolaan kawasan hutan untuk tujuan khusus sebagaimana dimaksud dalam Pasal 8 dapat kepada: a. masyarakat hukum adat dan d. Lembaga sosial dan keagamaan.

Pasal 71 ayat (1) "Masyarakat berhak mengajukan gugatan perwakilan ke pengadilan dan atau melaporkan ke penegak hukum terhadap kerusakan hutan yang merugikan kehidupan masyarakat". Ayat (2) "Hak mengajukan gugatan sebagaimana dimaksud pada ayat (1) terbatas pada tuntutan terhadap pengelolaan hutan yang tidak sesuai dengan peraturan perundang-undangan yang berlaku".

Pasal 72 "Jika diketahui bahwa masyarakat menderita akibat pencemaran dan atau kerusakan hutan sedemikian rupa sehingga mempengaruhi kehidupan masyarakat, maka instansi pemerintah atau instansi pemerintah 
daerah yang bertanggung jawab di bidang kehutanan dapat bertindak untuk kepentingan masyarakat".

Harus dijelaskan bawa hukum ini belum diterapkan secara luas di Indonesia, termasuk di hulu Sungai Bahau dan tidak ada kaitan yang langsung dengan konsep tana' ulen. Sebagian masyarakat di Sungai Bahau tahu tanahnya adalah tanah milik negara (menurut pemerintah) karena sudah status taman nasional, tetapi tidak semuanya setuju dengan status ini. Masih belum jelas apakah mereka mau terapkan hukum "hutan adat" yang baru dengan arti bahwa tana' ulen sebetulnya tanah negara, atau apakah mereka ingin menuntut status lain. Di samping ini, belum jelas juga apakah pemerintah Kabupaten Malinau ingin terapkan hukum tersebut di TN Kayan Mentarang. 


\section{Bab 5 \\ Kesimpulan dan \\ Rekomendasi Kebijakan}

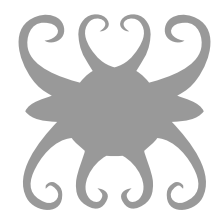

Menunjuk pada uraian di atas bahwa begitu besar ketergantungan masyarakat Dayak di sekitar TN Kayan Mentarang terhadap hutan: (1) hutan merupakan sumber kehidupan sebagai mata pencaharian utama, (2) keterkaitan budaya masyarakat Dayak terhadap hutan sangat tinggi, (3) timbal balik antara budaya dan ketergantungan ekonomi, dan secara ekologi berupa sistem unik, (4) masyarakat Dayak di sekitar TN Kayan Mentarang telah memiliki hukum adat secara lokal, (5) menimbang adanya pengakuan hutan adat berdasarkan undang-undang negara, (6) keterkaitan antara pelestarian (konservasi) hutan dengan kesejahteraan masyarakat Dayak di sekitar TN Kayan Mentarang, dan (7) mencegah konflik mengenai penggunaan lahan baik dari dalam maupun dari luar, maka dengan itu kami merekomendasikan agar pengelolaan hutan secara lokal oleh masyarakat asli setempat diberi status hukum yang sah berdasarkan undang-undang negara, agar dapat mencegah terjadinya konflik sehingga masyarakat asli mendapat hak untuk mengatur wilayahnya sendiri terhadap sumber pendapatan dan perekonomian yang dapat menjamin kelangsungan hidup mereka dan kelangsungan pembangunan. Sampai sekarang, dengan banyak ketidakpastian mengenai kebijakan kehutanan dengan keadaan Otonomi Daerah, masyarakat di Hulu Bahau masih belum punya hak atas wilayahnya secara sah. 
Ancaman terhadap pemanfaatan lahan hutan memerlukan adanya hukum negara yang kuat atas batas wilayah hutan dan hak atas pemanfaatan hutan yang adil dengan masyarakat. Hukum adat diakui dan bisa dipadukan dengan hukum negara untuk mencapai tujuan kesejahteraan, mata pencaharian, dan budaya. Dengan bertambahnya kebutuhan lahan, penting sekali batas wilayah desa mendapat perhatian untuk disahkan secara hukum dan administrasi pemerintahan untuk mencegah konflik antar warga desa satu dengan lainnya.

Batas wilayah desa penting juga mendapat pengesahan status hukum untuk mencegah timbulnya konflik dari luar terhadap kepentingan pemanfaatan lahan, misalnya para investor yang ingin menanamkan modalnya untuk mengambil lahan yang luas atau pencari hasil hutan seperti gaharu yang tidak memikirkan kelestarian hasil.

Pengaturan tata ruang untuk pembangunan daerah terhadap berbagai kepentingan dan rencana pembangunan juga perlu mengetahui batas-batas yang jelas misalnya terhadap wilayah desa, agar tidak terjadi perencanaan yang tumpang tindih dalam satu lokasi untuk berbagai kepentingan yang dapat menimbulkan konflik. Oleh sebab itu penetapan dan pengesahan batas-batas wilayah desa berdasarkan undang-undang negara sangat diperlukan bagi kepentingan berbagai pihak, terutama bagi desa itu sendiri, pemerintah daerah, dan negara.

Oleh sebab itu jika tidak ada pembatasan luas lahan, maka pembangunan dengan menggunakan peralatan modern akan selalu kekurangan lahan. Sehingga apabila tidak ada batas dan hak yang jelas dan sah untuk penggunaan lahan pada berbagai kepentingan termasuk hak-hak untuk masyarakat asli maka akan terjadi konflik. Konflik bisa terjadi antara masyarakat dengan pemakai lahan di sekitarnya (HPH, pertambangan, transmigrasi), akibat konflik ini semua pihak akan rugi dan tidak ada yang diuntungkan. Yang untung adalah apabila semua pihak telah mendapat hak dengan batas-batas yang jelas dan mendapatkan keputusan berdasarkan undang-undang negara yang ditetapkan oleh pemerintah. Sehingga apabila terjadi 
konflik masyarakat dapat mempertahankan hak berdasarkan "SK" masing-masing dan dapat ditempuh melalui jalur hukum tanpa kekerasan. 


\section{Catatan Kaki}

${ }^{1}$ Perbedaan tulisan istilah Kenyah Leppo' Ké di sini dengan yang ada di Puri (2001) mencerminkan perbedaan pendapat sesuai dengan pengalaman penulis utama sebagai orang Kenyah asli.

${ }^{2}$ Nama lokal ditulis dengan huruf tebal dan miring.

${ }^{3}$ Kebanyakan jamur (kulat) mengandung racun yang mematikan. Kulat lung dapat membuat mabuk jika dimakan berlebihan.

${ }^{4}$ Beberapa jenis payang digunakan untuk membuat terasi melalui proses yang dibuat secara peragian.

${ }^{5}$ Ada cerita dari mulut ke mulut tentang kisah asal-usul pemanfaatan burung krukep sebagai obat. Konon dulu ada orang Kenyah patah tulang pada kakinya. Kemudian dia pergi mencari obat sampai dia menemukan anak burung krukep di sarangnya. Anak burung ini kemudian dipatahkan kakinya lalu diintip sampai induknya pulang. Setelah induknya datang dan dilihat kaki anaknya patah maka induk burung ini pergi mencarikan obat. Saat induknya pulang membawa obat, maka obat tersebut direbut oleh orang yang mengintip tadi. Obat inilah dipakai untuk mengobati orang yang patah tulang. Kemudian obat tersebut diperhatikan baik-baik, berasal dari jenis apa. Lalu diingat dan dipelajari. Namun sebagian besar orang sekarang menganggap bahwa burung tersebutlah sebagai obat, dan banyak orang sudah memakainya sampai sekarang. 
${ }^{6}$ Arak adalah minuman tradisional khas Dayak Kenyah Hulu Sungai Bahau yang dibuat melalui proses peragian singkong kemudian disuling. Arak (atau chiu) ini diminum secara teratur untuk memulihkan tenaga dan menyegarkan badan.

${ }^{7}$ Para pencari gaharu secara tradisional melukai batang kayu gaharu dengan menggunakan kampak atau parang. Apabila tidak ada isi yaitu endapan ekstraktif yang berwarna gelap, maka kayu tersebut dibiarkan hidup dan ditinggalkan. Adanya luka ini merangsang pohon gaharu memproduksi resinnya. Tahun berikutnya mereka datang lagi memeriksa bagian kayu yang luka tersebut, umumnya sudah ada endapan ekstraktif di sekitar bagian kayu yang luka tersebut.

${ }^{8}$ Harga rotan jatuh karena tidak ada pembeli, akibat adanya larangan ekspor rotan mentah. Apabila pemerintah membuka ijin ekspor, kemungkinan harga rotan akan membaik.

${ }^{9}$ Satu batang rotan sega (Calamus caesius) dibelah menjadi empat kemudian diambil kulitnya diraut untuk menjadi bahan anyaman. Satu blanyat ukuran sedang yaitu tinggi $32 \mathrm{~cm}$ diameter $15 \mathrm{~cm}$ membutuhkan 180 lembar rautan rotan yang berasal dari 45 sampai 50 batang rotan sepanjang 5 meter.

${ }^{10}$ Merayakan kepala yang dipotong dan berdoa sesudah memanen hasil hutan, mendoakan hasil panen, serta membuang sial dan mencuci kampung (lihat halaman 67).

${ }^{11}$ Hasil penelitian Colfer 1979/80, studi kasus suku Dayak Kenyah Uma' Jalan di Kalimantan Timur, dalam rangka proyek penelitian MAB (Man and Biosphere) mengenai Interaction between People and Forest in East Kalimantan, dalam Colfer 1997.

${ }^{12}$ Sungai Benuang tempat pembuangan air yang berasal dari lokasi tambang batu bara. Air yang menggenang di dalam tambang dipompa ke atas dengan mesin kemudian dialirkan ke Sungai Benuang.

${ }^{13}$ Apui Njau adalah Kepala Adat Besar Hulu Bahau tahun 1925 sampai 1967. Lahir tahun 1901, kemudian dipenjarakan oleh Belanda di Batavia (sekarang Jakarta) pada tahun 1920 sampai 1925 karena 
membunuh orang Bulungan. Selama dalam penjara beliau belajar menulis dan bersawah. Setelah kembali tahun 1925 beliau mengajarkan orang membuat sawah di hulu Sungai Bahau. Apui Njau wafat tahun 1967 di Long Alango.

14 Sayangnya, dalam rangka proyek ini tidak ada kesempatan mengumpulkan data mengenai kemarau panjang selain yang ini.

${ }^{15}$ Sifat genetik yang dimaksudkan di sini adalah sifat-sifat tumbuhan tersebut, baik yang nampak maupun yang tidak nampak. Sifat yang nampak misalnya: warna, ukuran buah, ukuran daun, panjang, pendek, dan sebagainya. Sifat yang tidak nampak misalnya: rasa manis, asam, ketahanan terhadap penyakit, dan lain-lain.

${ }^{16}$ Orang Dayak melindungi hutan bukan berarti hutan tidak boleh dimanfaatkan sama sekali, melainkan justru untuk mengambil manfaatnya yaitu binatang buruan.

17 Ba'bui satung arti katanya sebagai berikut : $\boldsymbol{b} \boldsymbol{a}^{\prime} \boldsymbol{b} u \boldsymbol{i}=\mathrm{babi}$, satung=berenang, nyatung=sedang berenang, matung=hanyut.

${ }^{18}$ Selarang artinya ikan patin, karena ikan patin sangat suka makan buah ini.

${ }^{19}$ Contoh nama-nama di sini diambil dari berbagai bahasa sub suku Dayak Kenyah.

${ }^{20}$ Ada kaitan antara hukum adat dengan hukum negara, contoh: dalam hukum adat yang ditetapkan tanggal 20 Juni 1996, hasil Pesta Panen Gabungan di Long Tebulo, pada Pasal V ayat d. menyebutkan bahwa jika terjadi perkelahian yang menyebabkan korban jiwa diserahkan kepada polisi. Selain itu juga terdapat kaitan hukum adat dengan pemerintah pada Pasal XXV ayat a. (dapat dilihat pada Bab IV B. Hukum Adat Terhadap Hutan).

${ }^{21}$ Pasal X Ayat a. bunyinya: Terjadi pelanggaran atas watas ladang di antara masyarakat desa itu sendiri yang tadinya diberi tanda/disepakati oleh kedua belah pihak yang berbatasan ladang pada waktu menebas hingga menebang ternyata pada waktu menugal (karena sudah bersih) satu pihak menggeser/merubah tanda tersebut, dikenakan denda: 1 
buah parang biasa diserahkan kepada yang menuntut. Ayat b, bunyinya: Terjadi perebutan/keributan mengenai watas perladangan antara desa langsung ditangani oleh Kepala Adat Besar Hulu Bahau dengan rasa kekeluargaan/pertimbangan-pertimbangan kebijaksanaan bersama dari kedua hakim-hakim adat yang bersangkutan, sesuai hasil musyawarah para Kades-kades Hulu Bahau di Apau Ping.

${ }^{22}$ Pasal XI bunyinya : Hasil hutan, daerah perladangan, persawahan, kayu yang dapat dimanfaatkan untuk bahan bangunan, perahu dan lain-lain tidak harus pada titik garis watas desa yang telah ditetapkan untuk memperoleh sesuatu seperti tersebut di atas tetapi hendaklah kesemuanya melalui ijin dari desa yang bersangkutan dengan rasa kekeluargaan (boleh lewat) khusus 9 desa di Hulu Bahau, periksa keputusan Kepala-kepala Desa Hulu Bahau pada surat No. 01/ K.A.B./II/1996, tertanggal 3 Februari 1994, di Apau Ping.

${ }^{23}$ Tana' ulen juga disebut polong ulen yang artinya hutan larangan. 


\section{Pustaka}

Anau, Njau. 1999. Sejarah suku Kenyah Leppo' Ke dan Nyibun di Kecamatan Long Pujungan. In: Eghenter, C. adn Sellato, B. (eds.) Kebudayaan dan pelestarian alam: penelitian interdisipliner di pedalaman Kalimantan. PHPA/The Ford Foundation/WWF, Jakarta, Indonesia.

Apui, Anye 1996. Keputusan musyawarah Kepala-Kepala Desa/ Kepala Adat Hulu Bahau di Long Tebulo tahun 1996. 7 halaman.

Colfer, C. et al. 1997. Peladang berpindah di Indonesia: perusak atau pengelola hutan? Produksi padi dan pemanfatan hutan Uma' Jalan di Kalimantan Timur.

Eghenter, C. and Sellato, B. (eds.) 1999. Kebudayaan dan pelestarian alam: penelitian interdisipliner di pedalaman Kalimantan. PHPA/ The Ford Foundation/WWF, Jakarta, Indonesia.

Hartadi, I. 1996. Daftar tumbuhan gaharu yang termasuk dalam CITES dan masuk ke dalam Apendix II. Database WWF/IP Jakarta.

Momberg, F., Puri, R.K., and Jessup, T. 2000 Exploitation of gaharu and forest conservation efforts in the Kayan Mentarang National Park, East Kalimantan, Indonesia. In: Zerner, C. (ed.) People, plants and justice. Columbia University Press, New York.

Puri, R.K., 2001. The Bulungan ethnobiology handbook. CIFOR, Bogor, Indonesia. 
Puri, R.K., 1997. Hunting knowledge of the Punan Benalui of East Kalimantan, Indonesia. Unpublished Ph.D. Dissertation. University of Hawaii, Department of Anthropology.

Soedjito, H. dan Kartawinata, K., 1987. Keberadaan masyarakat dan budaya Dayak dalam kaitannya dengan kelestarian hutan hujan tropik di Kalimantan. Makalah untuk diskusi "Kearifan Tradisional Masyarakat Dayak dalam Berladang dan Pengendalian Kebakaran Hutan" dalam rangka Pekan Budaya: Masyarakat Dayak dan Hutan Kalimantan (Kerudung Asap di Kalimantan). Taman Ismail Marzuki, Jakarta tanggal 30 Nopember dan 1 Desember 1987.

Soedjito, H. 1991. Environmental knowledge and biological diversity in East Kalimantan, "Forest, Field, and Sea: Folklife in Indonesia". 65-68.

Uluk, A. dan Wollenberg, E. 1998. Pemanfaatan hutan dan ekonomi rumah tangga di kawasan Taman Nasional Kayan Mentarang (versi Bahasa Kenyah. World Wide Fund for Nature and CIFOR report. Wollenberg, E. 2001. Incentives for collecting gaharu (fungal-infected Wood of Aquilaria spp.; Thymelaeaceae) in East Kalimantan. Economic Botany 55(3): 98-110.

Wollenberg, E., Nawir, A.S., and Uluk, A. 2000. Income is not enough: the effect of economic incentives on forest conservation. CIFOR Working Paper No. 21. CIFOR, Bogor, Indonesia.

Wollenberg, E. dan Uluk, A. 1998. Pemanfaatan Hutan dan Ekonomi Rumah Tangga di Kawasan Taman Nasional Kayan Mentarang (versi Bahasa Indonesia), World Wide Fund for Nature and CIFOR report. 


\section{Bab 1}

\section{Pendahuluan}

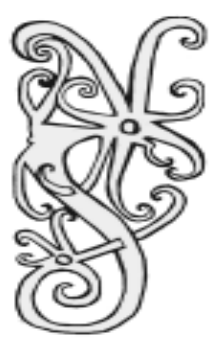

Konversi hutan untuk berbagai kepentingan telah memusnahkan jutaan hektar hutan, terutama setelah keadaan Otonomi Daerah. Pembukaan hutan oleh pemegang IPPK (Izin Pemungutan dan Pemanfaatan Kayu), HPH (Hak Pengusahaan Hutan), perkebunan, pertambangan, dan konversi untuk kepentingan lain telah mendesak para pengelola tradisional yang mendiami wilayah tersebut selama ratusan tahun. Wilayah mereka menjadi semakin sempit, sumber daya alam berkurang, sedangkan kehidupan mereka di bidang pembangunan ekonomi kurang mendapat perhatian.

Sebagian besar masyarakat di Indonesia belum mengetahui ketergantungan masyarakat asli yang mendiami wilayah di pedalaman terhadap hutan, yang merupakan hubungan timbal balik secara harmonis atau selaras. Misalnya, di sekitar Taman Nasional (TN) Kayan Mentarang di Kabupaten Malinau dan Nunukan, Kalimantan Timur, ada sekitar 25.000 penduduk yang hampir semua kebutuhan mereka, termasuk makanan, bahan bangunan, obat, pendapatan tunai, sumber air dan budaya mereka sangat tergantung pada hutan. Tulisan ini dimaksudkan untuk menjelaskan ketergantungan masyarakat asli terhadap hutan, dan pengaruh desakan dari pihak luar sehingga dapat dimengerti dampak kerusakan hutan terhadap kehidupan masyarakat lokal. Di samping itu juga untuk memberi masukan kepada kebijakan 
pemerintah guna mengatasi atau mencegah masalah dan konflik. Kami jelaskan ketergantungan masyarakat dari aspek ekonomi maupun budaya.

Tulisan ini berdasarkan hasil penelitian sosio ekonomi rumah tangga yang merupakan kerjasama CIFOR dan World Wide Fund for Nature - Indonesia Programme pada tahun 1995-96, dan penelitian tindak lanjut sampai tahun 1998, yang telah dilakukan di sekitar TN Kayan Mentarang. Kegiatan penelitian ini dilakukan di tiga kecamatan yang berada di dalam atau sekitar TN Kayan Mentarang yaitu Kecamatan Kerayan, Mentarang, dan Pujungan. Metode yang dipakai termasuk survei rumah tangga (memakai random sampling), wawancara responden utama, dan pengamatan langsung. Laporan ini terfokus pada hasil dari tiga desa di Kecamatan Pujungan yaitu: Long Pujungan dengan 47 Kepala Keluarga (KK), Long Alango $40 \mathrm{KK}$, Apau Ping $32 \mathrm{KK}$, karena penulis paling lama melakukan penelitian di daerah ini dan juga terdapat lebih banyak data pendukung (lihat peta 1). Untuk hasil lain dari penelitian ini dan penjelasan metode, lihat Wollenberg et al. 2001, Uluk dan Wollenberg 1998, Wollenberg dan Uluk 1998. Angka-angka yang dilaporkan di sini adalah jumlah atau prosentase per desa dari tiga desa tersebut.

\section{A. ORANG DAYAK DI SEKITAR TAMAN NASIONAL KAYAN MENTARANG}

Orang Dayak di sekitar TN Kayan Mentarang terdiri dari berbagai subsuku Dayak antara lain: Kayan, Kenyah, Lundayeh, Merap, Punan, Saben, Tagel, dan lain-lain. Mereka adalah pengelola hutan yang bijak, yang telah mengelola hutan selama berabad-abad tanpa menimbulkan kemusnahan hutan, sehingga sampai sekarang kawasan hutan seluas 1,4 juta ha yang ditetapkan sebagai TN Kayan Mentarang masih utuh. Sistem pengelolaan yang diterapkan secara turun-temurun mewariskan hutan utuh yang dapat dinikmati oleh anak cucu mereka pada generasi sekarang. Berdasarkan hasil penelitian ini, dan pengalaman salah seorang penulis penduduk asli setempat (selama 
PENDAHULUAN

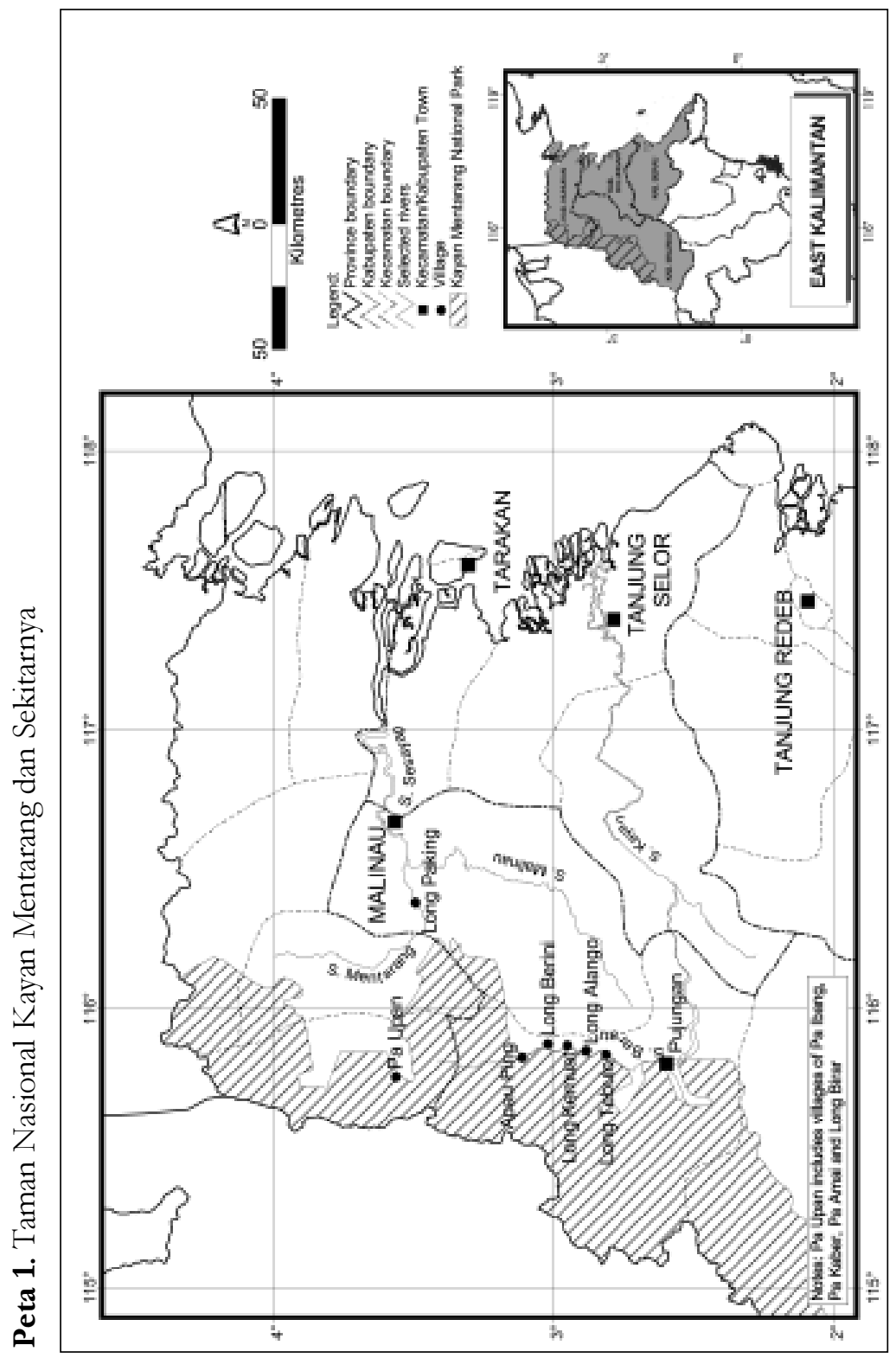


28 tahun), hampir seluruh hidup orang Dayak di sekitar TN Kayan Mentarang tergantung pada hutan. Kehidupan masyarakat tidak dapat dipisahkan dengan hutan. Untuk informasi mengenai sejarah Hulu Bahau, lihat Sellato (2001), Anau (1999), Eghenter dan Sellato (1999).

Hasil hutan bukan hanya merupakan pendapatan sampingan, tapi hubungan antara hutan dan masyarakat Dayak di sekitar TN Kayan Mentarang bagaikan air dengan ikan. Ikan tidak bisa hidup tanpa air, ikan bernafas dan mencari makanan dalam air. Begitu pula bagi orang Dayak di sekitar TN Kayan Mentarang, mereka tidak bisa hidup tanpa hutan yang lestari. Mereka memenuhi hampir semua kebutuhan pokoknya dari dalam hutan.

Tradisi dan budaya masyarakat Dayak sangat berkaitan dengan hutan. Orang Dayak mengambil bahan upacara yang berasal dari hutan. Nama-nama orang Dayak diambil dari nama-nama binatang maupun tumbuh-tumbuhan di hutan. Mereka mencari nafkah dengan cara menirukan kehidupan binatang untuk mengelabui binatang buruannya di hutan.

Berkenaan dengan adanya kemarau panjang tahun 1997-98 yang menyebabkan panen gagal dan sulitnya transportasi melalui sungai telah menyebabkan persediaan barang sangat berkurang. Ditambah lagi adanya krisis moneter yang mengakibatkan harga barang yang membumbung naik, telah menyebabkan orang Dayak lebih menggantungkan diri pada hasil hutan.

\section{B. PERMASALAHAN YANG DIALAMI MASYARAKAT}

Kehidupan masyarakat asli yang sangat tergantung pada hutan sekarang terancam oleh persaingan lahan dan konflik atas hutan untuk berbagai kepentingan pembangunan. Pemanfaatan lahan di bidang pertambangan, eksploitasi hutan atau penebangan kayu, perkebunan intensif, dan lain-lain telah menghasilkan devisa bagi negara. Di lain pihak, kepentingan para investor telah menguasai sebagian besar lahan dan menyudutkan para petani ekonomi lemah ke wilayah yang sempit, terbatas, dan tertinggal. Pengambilan hasil bumi dalam sekala besar 
juga telah mengakibatkan pencemaran, air keruh, dan limbah kotor yang menjadi bagian untuk penduduk asli.

Politik pembangunan telah merugikan hak-hak adat dan pengelolaan secara lokal baik di bidang ekonomi, maupun sosial dan budaya yang mengakibatkan cepatnya sistem dan pola kehidupan masyarakat adat hancur. Hak-hak masyarakat adat dikorbankan untuk pembangunan yang terutama dinikmati kaum elit. Desakan dan intimidasi telah membingungkan sebagian besar warga yang tinggal di pelosok-pelosok.

Sejak adanya reformasi dan kebijakan desentralisasi, ada perdebatan mengenai siapa yang seharusnya mempunyai hak atas kawasan hutan dan siapa yang mendapat hak untuk mengelola hutan. Salah satu konsep hutan kemasyarakatan yang dikenal dengan istilah tana' ulen telah dibahas dalam lokakarya tahun 1998 di Tanjung Selor. Konsep tana' ulen ini dipakai sebagai landasan untuk meningkatkan keterlibatan masyarakat lokal dalam pengelolaan hutan. Kebijakan kehutanan terhadap tana' ulen diperlukan oleh masyarakat lokal untuk mendapatkan kepastian hak atas tanah, hutan, dan kekayaan di dalamnya agar dapat dikelola secara mandiri berdasarkan aturan adat yang disetujui oleh pemerintah. Kebijakan mengenai tana' ulen bisa menjadi upaya alternatif atau inovatif untuk menghindari dan mencegah konflik dalam penggunaan lahan dan hak atas tanah. 
PENGATURAN HUTAN 


\section{Bab 2}

\section{Peranan Hutan bagi Masyarakat Dayak di Sekitar Taman Nasional Kayan Mentarang}

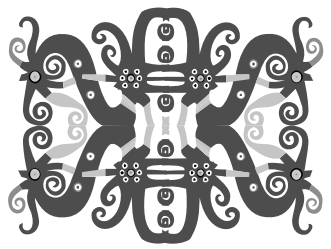

Dalam tulisan ini diuraikan peranan hutan bagi masyarakat Dayak di sekitar TN Kayan Mentarang yang meliputi kebutuhan jenis tumbuhan, binatang, serangga, ikan, jamur, dan lainlain. Contoh-contoh yang disebutkan dalam tulisan ini merupakan jenis-jenis yang paling umum dipakai oleh masyarakat. Jenis-jenis lainnya dapat dilihat dalam Lampiran 1. Lihat juga Puri (2001) untuk penjelasan jenis tumbuhan dan binatang yang dipakai oleh masyarakat setempat. Jenis hasil hutan yang disebutkan termasuk yang berasal dari hutan primer maupun sekunder. Jenis tumbuhan dari tanaman pertanian dan hewan peliharaan dibahas sebagai pembanding. Jumlah jenis hasil bumi yang dipanen diringkas per golongan dalam Lampiran 2 dan 3. Semua nama lokal jenis tumbuhan dan binatang yang dipakai adalah dalam bahasa Dayak Kenyah Leppo’ Ké. ${ }^{2}$

\section{A. HUTAN MERUPAKAN SUMBER KEBUTUHAN POKOK DAN EKONOMI MASYARAKAT DAYAK}

Hasil penelitian ini menunjukkan bahwa masyarakat Dayak di sekitar TN Kayan Mentarang sangat tergantung pada berbagai jenis hasil hutan. Berdasarkan hasil perhitungan data tercatat sebanyak 139 
sampai 214 jenis hasil hutan yang dimanfaatkan untuk berbagai kepentingan dalam waktu satu tahun (1995-96), antara lain sebagai sumber makanan, obat, bahan bangunan, sumber penghasilan uang tunai, upacara dan kebudayaan. Jumlah ini hanya sebagian-mungkin 25 persen - dari semua jenis hasil hutan yang mereka kenal. Jenis tumbuhan yang berasal dari tanaman pertanian sekitar 23 sampai 35 jenis atau hanya sekitar $11 \%$ sampai $25 \%$ dari jumlah semua hasil bumi yang dipakai.

\section{Hutan Sebagai Sumber Bahan Makanan}

\section{a. Di hutan diperoleh protein dari berbagai jenis binatang, serangga dan ikan}

Masyarakat di sekitar TN Kayan Mentarang memperoleh protein dari berbagai jenis binatang buruan. Jenis-jenis paling umum yang menjadi kesukaan masyarakat adalah ba'bui (Sus barbatus) (lihat Foto 1), uca' ano (Muntiacus muntjac), payau (Cerius unicolor), pelanuk (Tragulus javanicus), setung umung (Hystrix brachyura), dan banyak jenis binatang lainnya dapat dilihat dalam tabel terlampir. Jenis binatang yang dipanen dalam satu tahun rata-rata 9 sampai 14 jenis per rumah tangga per kampung, dan 100\% merupakan binatang liar.

Beberapa jenis serangga juga merupakan sumber protein. Sejenis larva kumbang palem dari ordo Coleoptera yang disebut su'et (Rhynchophorus ferrugineus) enak dimakan dan sangat digemari. Jenis lainnya berasal dari larva coleoptera yang hidup di kayu keras, misalnya ulet samban (Monochamus spp.) diambil dari kayu seleman (Weinmannia blumei). Selain itu, larva berbagai jenis lebah yang disebut tilo layuk (Apis dorsata) biasanya diambil di pohon kayu tanyit (Koompassia excelsa). Jenis belalang dari ordo Orthoptera yang disebut pau (Famili Acrididae) biasanya banyak ditemukan di rumputrumputan. Kurang lebih 4 sampai 11 jenis serangga dipanen per rumah tangga per desa di sekitar TN Kayan Mentarang dalam jangka waktu satu tahun. 
Sungai-sungai yang terdapat di dalam hutan kaya dengan berbagai jenis ikan dan jumlahnya sangat banyak. Jenis-jenis ikan yang paling sering ditemukan adalah pasa' (Lobocheilos faliifer), selareng (= patin: Pangasius niewenhuisi), salap (Barbodes balleroides), atuk buleng (=dungan: Hampala macrolepidota bimaculata), padek (Tor if. tambra), teliken (Mystus wyckii), kati (=lele: Chana sp.), betelo (Rasbora sp.), munjuk (=belevan: Osteochilus sp.), tekasang ka (Parbomaloptera sp.), telan (Mastacembelus armatus) dan lain-lain. Rata-rata ada 9 sampai 16 jenis ikan dipanen per keluarga per desa di sekitar TN Kayan Mentarang.

Foto 1. Babi hutan dan dagingnya di L. Tebulo

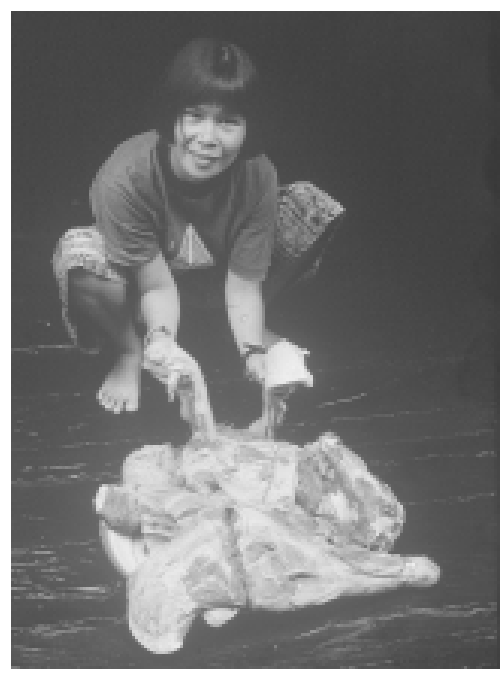

b. Di hutan diperoleh karbohidrat dari berbagai jenis palem dan umbi-umbian

Beberapa rumah tangga di sekitar TN Kayan Mentarang memperoleh karbohidrat dari palu atau sagu dari berbagai jenis palem, misalnya nanga (Eugeissona utilis), talang (Arenga undulatifolia), bo'e (Arenga brevipes), dan lain-lain. Ada satu sampai empat jenis sagu yang dipanen per rumah tangga per desa, sekitar 16\% sampai 19\% dipanen dari 
yang tumbuh liar di hutan, kecuali di Apau Ping 0\% (mungkin memanen sagu dari yang ditanam di kebun, atau kebetulan, tidak panen sagu tahun itu). Salah satu kelompok masyarakat yang sangat tergantung pada sagu adalah masyarakat Punan. Mereka tidak masuk dalam survei ini tetapi diketahui mereka sangat tergantung pada sagu sebagai makanan pokok kalau sedang jalan di hutan. Selain dari palem, karbohidrat juga dapat diperoleh dari berbagai jenis umbi-umbian yang tumbuh secara liar di dalam hutan. Sebagai contoh lundai (Xanthosoma sp., Colocasia gigantea), luan si'ik (Dioscorea pentaphylla), luan bala (Dioscorea alata), dan lain-lain.

Makanan ini sangat penting bagi orang yang sedang melakukan perjalanan di dalam hutan, sehingga apabila sewaktu-waktu mereka menginap di hutan tidak perlu membawa bekal yang banyak dari rumah. Apabila kehabisan beras, makanan inilah yang banyak dimanfaatkan. Selain itu makanan tersebut di atas juga penting untuk makanan selingan atau makanan tambahan apabila bosan dengan jenis makanan pokok.

Sumber karbohidrat dari hutan penting bagi orang Dayak sebagai cadangan bahan makanan untuk dimanfaatkan di musim paceklik, apabila ladang gagal panen di musim kemarau. Menurut pengalaman pada tahun 1997-98 di daerah Sungai Bahau masyarakat mengalami gagan panen karena adanya musim kemarau panjang oleh pengaruh El Niño. Ditambah lagi dengan adanya krisis moneter pada waktu itu, di mana persediaan beras habis dan harga membubung tinggi. Beras yang biasanya seharga Rp. 1.000 per kg, melonjak menjadi Rp. 9.000 per kg. Hal ini selain disebabkan kehabisan stok dalam negeri, beras impor yang harganya sekitar Rp. 2.500 per kg di Tarakan, harus diangkut dengan pesawat MAF (Missionary Aviation Fellowship) dengan ongkos Rp. 6.000 per kg, kemudian pengusaha mengutip keuntungan Rp. 500 per kg. Masyarakat yang umumnya ekonomi lemah tidak mampu menjangkau harga tersebut. Di sinilah terbukti bahwa hutan merupakan lumbung hidup bagi masyarakat Dayak, apabila ladangnya gagal, mereka masih memiliki banyak jenis sumber bahan makanan yang tumbuh secara liar di hutan. 


\section{c. Di hutan diperoleh vitamin dari sayur dan buah-buahan}

Di hutan terdapat berbagai jenis tumbuhan yang digunakan oleh masyarakat sebagai sayur. Beberapa jenis tumbuhan yang paling sering digunakan dalam kehidupan sehari-hari antara lain kelompok pakupakuan, misalnya: paku bala (Stenoclaena palustris), paku bai (Dipląium esculentum) (lihat Foto 2), paku pa'it (Athyrium sorongonense), paku julut (Nephrolepis bisserata), dan lain-lain. Berbagai jenis pucuk daun, ubut, dan rebung (lihat Foto 3) juga diambil sebagai sayuran. Ubut dari pisang hutan ada beberapa jenis seperti ubut utai (Musa sp1.), lebem (Musa sp2.), dan sawan (=punyang: Musa sp3). Ubut dari jenis palem dan ubut rotan hampir semua dapat dimakan, contohnya adalah ubut talang (Arenga undulatifolia), ubut nanga(Eugeissona utilis), ubut nyibung (Oncosperma horridum), ubut uwai tebungen (Calamus ornatus), ubut uwai balamata (Calamus sp1.), ubut uwai pa'it (Calamus sp2.). Ubut dari jenis jahe-jahean hutan dari famili Zingiberaceae banyak dimakan misalnya beberapa jenis nyanding (Etlingera elation), ucuk kuang (Nicolaia speciosa), ubut seriteng, ubut sua', ubut tepo', dan ubut tite'. Selain itu berbagai jenis jamur seperti: kulat long (Amanita sp.) (lihat Foto 4), kulat long belabau (Russula cyanoxantha), kulat tau (Craterellus cornucopides), kulat kedet

Foto 2. Paku bai (Apau Ping)

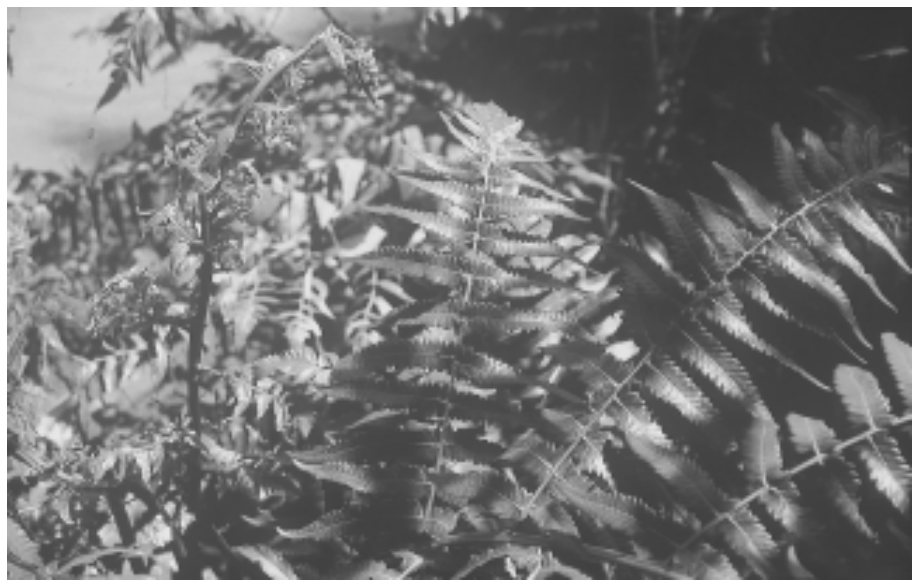


Foto 3. Persiapan ubud bambu di Apau Ping

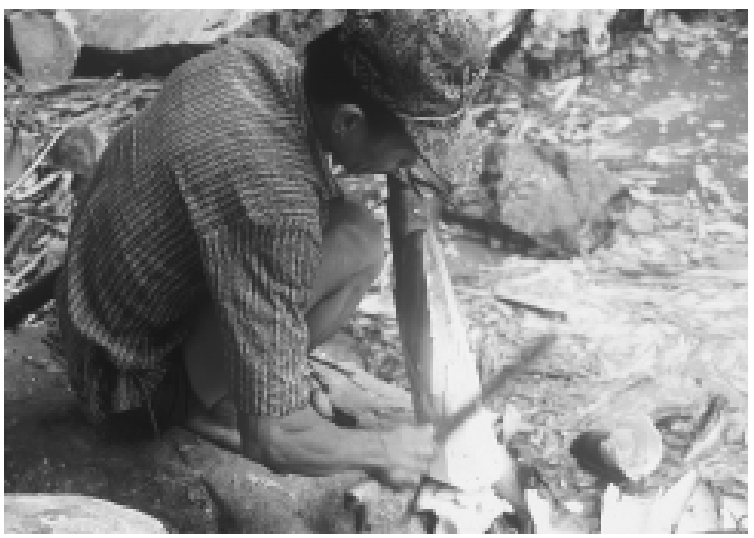

Foto 4. Kulat long

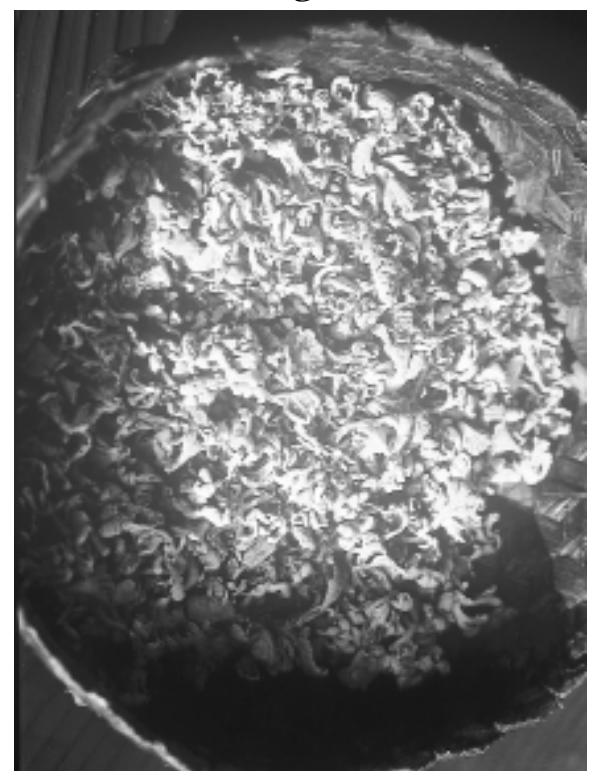


(belum diidentifikasi), kujep (Pleurotus sp.), kulat palan (Agaricus angustus), kulat ulek (Agaricus ariensis), kulat sulip (Hydnum repandum), kulat bulu (Lactarius deliciosus), dan lain-lain. Rata-rata ada 17 sampai 25 jenis sayuran yang dimanfaatkan per keluarga per kampung dalam satu tahun dan antara $72 \%$ sampai $85 \%$ dipanen dari yang tumbuh secara liar di hutan baik di hutan primer maupun hutan sekunder.

Buah-buahan sebagai sumber vitamin yang penting dan sangat digemari sebagai contoh adalah dian da'un (Durio oxleyanus), dian kalang (Durio zibethinus), isau bala (Dimocarpus longan ssp. malesianus var. malesianus), isau bileng (Dimocarpus longan ssp1.), bua' a'bung (Nephelium ramboutan-ake), bua' sanggit (Nephelium lappaceum), bua' unjing (Nephelium maingayi), berenyiu (Mangifera caesia), mangga (Mangifera indica), alim (Mangifera pajang), nakan (Artocarpus integer), kian (Artocarpus odoratissimus), basut (Artocarpus lanceifolius), bitung (Garcinia mangostana), langset (Lancium domesticum), settai (Baccaurea macrocarpa), kelepesso (Baccaurea lanceolata), konye (Baccaureapariiflora), keramo' (Dacryodes rostrata), mejalin (Xanthophyllum scortechinii), mejalin batu (Xanthophyllum exelsa), dan lain-lain. Berdasarkan hasil penelitian ini diketahui bahwa rata-rata ada 8 sampai 12 jenis buahbuahan yang dipanen per keluarga per kampung. Sekitar 17\% sampai $38 \%$ dipanen dari hutan liar. Selebihnya dipetik dari hasil yang ditanam di kebun.

\section{d. Di hutan diperoleh bumbu untuk masakan sehari-hari}

Sebagian bumbu yang dipakai dalam kehidupan sehari-hari berasal dari tumbuhan liar yang terdapat di hutan. Hasil penelitian ini menunjukkan rata-rata ada 6 sampai 10 jenis bumbu yang digunakan per keluarga. Bahan bumbu tersebut yang berasal dari hutan liar berkisar antara 70\% sampai 73\%. Tumbuhan dari hutan liar yang paling umum dijadikan bumbu adalah: bekkai lan (Pycnarhena cauliflora) (lihat Foto 5), bekkai lanya (Coscinium miosepalum), belengla (Litsea cubeba), uba tepuh (Eugenia sp.) sejenis daun salam, ulem (Solanum torum), dan lain-lain. Bahan bumbu yang lain diambil dari hasil yang ditanam di kebun. 
Foto 5. Bekkai yang siap untuk dipakai (L. Alango)

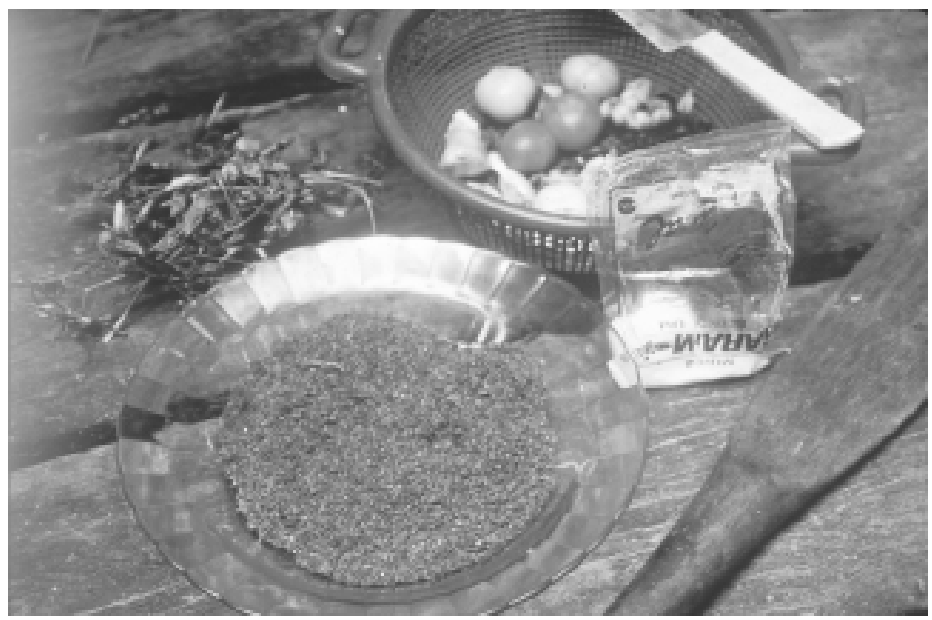

Selain yang telah disebutkan di atas, ada biji-bijian yang berasal dari tumbuhan liar di hutan dapat dimakan dan sangat disukai baik sebagai sayur, bumbu, atau dimakan langsung. Sebagai contoh adalah: beta (Parkia speciosa), payang kayu (Pangium edule), payang kure' (Aleurites moluccana), payang salap (Sumbariopsis albicans), payang aka (nama ilmiah tidak diketahui), bua' bangan (Castanopsis argentea), dan lain-lain. Pada umumnya orang-orang di kampung suka makan payang . Orang di kampung mengatakan, "jika ada payang, ikan terasa tawar", suatu ungkapan yang menyatakan bahwa payang sangat enak.

Kebutuhan keluarga untuk minyak makan dapat terpenuhi dari lemak babi hutan (ba'bui, Sus barbatus) yang digoreng sehingga mengeluarkan banyak minyak. Minyak inilah yang digunakan untuk kebutuhan memasak sehari-hari. Minyak babi tersebut adalah minyak khas yang disukai oleh orang Dayak, karena menurut mereka rasanya lebih enak kalau dibandingkan dengan minyak makan dari toko. Ada juga orang Dayak yang sudah pindah ke kota tapi mereka masih suka dengan minyak babi dari kampung. Kemungkinan untuk mendapatkan minyak dari babi hutan dapat mengurangi pengeluaran biaya, bahkan minyak tersebut dijual untuk menghasilkan uang tunai.

Pengamatan di Sungai Bahau membuktikan kebutuhan masyarakat Dayak terhadap minyak babi. Hasil buruan berupa babi 
lebih disukai daripada binatang yang lainnya. Jika seseorang pergi berburu dan mendapatkan beberapa ekor babi, maka yang lebih diutamakan dibawa pulang adalah lemak dan kulitnya. Apabila dagingnya tidak bisa dibawa pulang, maka ditinggalkan di dalam hutan. Mendapatkan babi gemuk dengan lemak yang tebal adalah kebanggaan. Di kampung biasanya orang-orang bertanya, "Berapa tebal lemaknya?". Babi yang gemuk umumnya mempunyai lemak setebal dua sampai empat jari.

\section{Hutan Sebagai Sumber Obat-obatan}

a. Di hutan diperoleh obat-obatan yang berasal dari tumbuhtumbuhan

Jenis tumbuhan obat yang paling umum dan sering dipakai antara lain: lembang pait (Eurycoma longifolia), lirang tana'(Euphorbia sp.), abung aa' (Ficus glomerata), a'bung bileng (Ficus hemsleyana), kayu pedek (=benua) (Macaranga triloba), paung lung (Xanthosoma sp.), kudip (Dillenia serata), aka lembo' (=aut bulu) (Passiflora sp.), aka pa'it (Fibraurea sp. dan Arcangelisia flava), sekau (Aquilaria sp.), simang, aka pejeling, kerenga mudung (Acorus calamus), dan lainlain. Hasil penelitian ini menunjukkan bahwa, setidaknya ada 4 sampai 12 jenis tumbuhan yang paling umum dipakai per keluarga per kampung untuk obat. Dari jenis-jenis tersebut 36\% sampai $43 \%$ berasal dari hutan liar. Soedjito 1991, mengemukakan bahwa telah diketahui tumbuhan obat-obatan sebanyak 150 jenis dari 132 genera dan 63 famili (hasil penelitian di daerah hulu Sungai Bahau).

\section{b. Di hutan diperoleh obat-obatan yang berasal dari binatang dan serangga}

Selain obat yang diperoleh dari tumbuhan, juga banyak obat-obatan yang diperoleh dari binatang. Sebagai contoh yang paling umum adalah: empedu buang (Helarctos malayanus), empedu kitan (Arctictis 
binturong), burung krukep (Centropus rectunguis), manuk ilang (Copsychus saularis), tanduk payau yang masih muda (Cerrus unicolor), janin pelanuk (Tragulus javanicus.), madu layuk (Apis dorsata), minyak dari ulet samban (Monochamus sp.) dan lain-lain. Empedu dari jenisjenis binatang ini jarang diambil, kadang-kadang dalam satu keluarga hanya memperolehnya satu kali dalam satu tahun. Penggunaan empedu sebagai obat dapat dilakukan dengan berbagai cara. Ada orang yang langsung memakannya, dan ada juga yang mencampur dengan minyak kelapa sebagai obat gosok untuk mengurut orang yang salah urat atau keseleo. Burung krukep digunakan untuk obat patah tulang. Sedangkan manuk ilang dipakai sebagai obat untuk anak-anak yang belum bisa berbicara atau gagap. Diyakini bahwa kalau anak tersebut diberi makan daging burung ini, maka bisa berbicara lancar, karena burung ini banyak bicara. Tanduk payau yang masih muda dan janin pelanuk biasanya direndam di dalam $\boldsymbol{a r a k}^{6}$ sebagai obat.

Sebagian orang mengambil bagian binatang bukan untuk obat, tetapi lebih suka menjual bagian dari binatang ini ke Malaysia karena harganya mahal di sana. Bagian binatang yang sering dijual adalah batu bangat (Presbytis hosei) dan batu settong umung (Hystrix brachyura). Orang Dayak di daerah Sungai Bahau pada umumnya tidak menggunakannya sebagai obat.

\section{Hutan Sebagai Sumber Bahan Bangunan dan Perahu}

Kayu-kayu di daerah Sungai Bahau yang dapat dimanfaatkan sebagai bahan bangunan dan perahu sangat banyak jenisnya. Masyarakat mempunyai banyak pilihan untuk memanfaatkan jenis-jenis yang disukai. Umumnya mereka memanfaatkan jenis-jenis kayu yang berkualitas baik sebagai pilihan utama, kemudian pilihan kedua untuk jenis kayu lainnya. Hasil penelitian ini menunjukkan bahwa ada 10 sampai 13 jenis kayu yang dimanfaatkan rata-rata per keluarga per kampung, dalam tahun 1995-96. Jenis-jenis tersebut 94\% sampai 95\% dipanen dari yang tumbuh liar di hutan. 


\section{a. Kayu-kayu yang penting untuk bahan bangunan rumah}

Masyarakat memilih beberapa jenis kayu yang memiliki kualitas baik sebagai bahan bangunan rumah dari segi kekuatan, tahan lama, serat halus, dan sebagainya. Berdasarkan penggunaannya, kayu-kayu tersebut dapat dikelompokkan sebagai berikut:

(1) Untuk tiang rumah antara lain; kayu belien (=ulin: Eusideroxylon zwageri), lemelai (Pternandra sp.), kayu merang (Diospyros sp.) dan lain-lain. Kayu-kayu ini kuat, tahan air, tidak diserang serangga, dan tahan lama karena tidak mudah lapuk. Kayu ulin dapat bertahan sampai ratusan tahun.

(2). Untuk gelagar, kaso, dan reng biasa digunakan kayu kapun (Dryobalanops lanceolata), penjae (=laran ba'bui: Hopea mengerawan), pilong (Ochanostachys amentacea), pung ubi (Santivia tomentosa), dan lain-lain. Kayu-kayu ini umumnya kuat, berserat lurus sehingga mudah dikerjakan apabila digergaji dan diketam.

(3). Untuk dinding biasanya dipakai kayu penjae (Hopea mengerawan) dan adau (Elmerrillia mollis)(lihat Foto 6). Kayu ini berserat halus, mudah diketam untuk dibuat halus permukaannya karena seratnya lurus.

(4). Untuk atap dibuat sirap dari kayu nyeliwai (Quercus argentea) dan kayu belien (Eusideroxylon zwageri), dan kayu benato (Shorea argentifolia Sym.). Kayu nyeliwai paling banyak digunakan di hulu Sungai Bahau. Kayu ini berserat lurus yang menyebabkan mudah dibelah menjadi ukuran kecil yang tipis, dan kayu ini tetap kuat karena adanya serat melintang yang besar (sel jari-jari kayu).

\section{b. Kayu-kayu yang penting untuk perahu}

Sarana transportasi di daerah Sungai Bahau adalah perahu. Perahu dipakai sehari-hari untuk pergi ke ladang, ke kampung tetangga, dan 
Foto 6. Kayu adau dijemur di hutan sebagai persiapan sebelum bangun rumah di Apau Ping

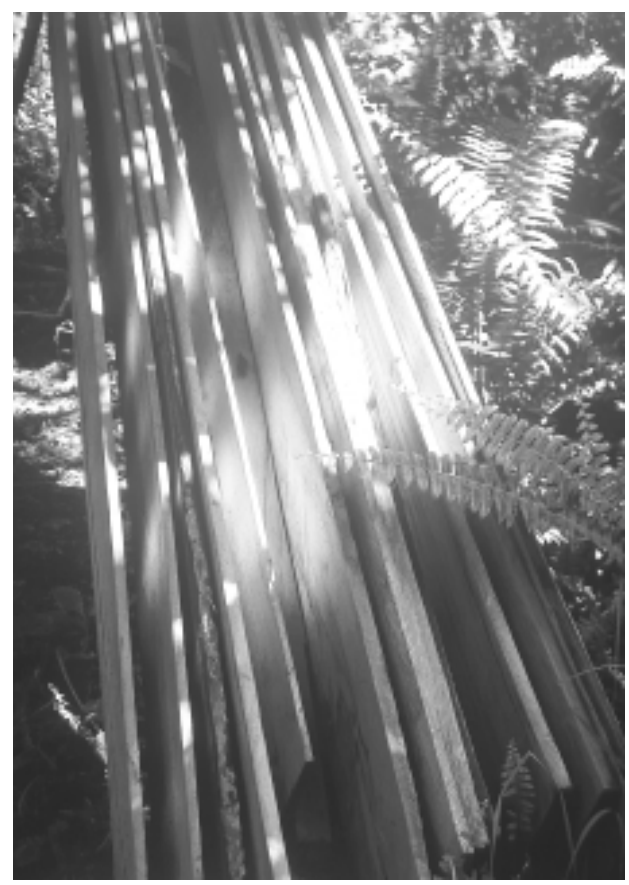

bepergian jauh misalnya ke kota. Di Sungai Bahau walaupun banyak jeram yang sangat berbahaya tetapi masyarakat di sana sudah biasa mondar-mandir melewati arus sungai yang deras. Perahu buatan sendiri biasa digunakan terjun di jeram kemudian ditarik ke atas batu. Masyarakat sudah mahir dengan dinamika air ketika banjir maupun dalam keadaan surut.

Kayu-kayu yang digunakan untuk membuat perahu juga merupakan kayu terpilih. Ada beberapa jenis kayu yang paling umum dipakai dapat dikelompokkan sebagai berikut:

(1). Untuk lunas atau batang alut (alas perahu) biasa digunakan kayu saleng (Diospyros borneensis), tebulo (Eugenia sp.), dan penjae (Hopea mengerawan). Karena kayu ini kuat dan licin, tidak lengket jika kandas di batu. 
(2). Untuk kapi (dinding perahu) biasa digunakan kayu adau (Elmerrillia mollis) dan penjae (Hopea mengerawan) karena kayu ini ringan, seratnya bagus, dan tahan air.

(3). Untuk dayung biasa digunakan kayu nyeliwai bala (Quercus argentea), nyeliwai bileng (Quercus gmelliflora). Kayu ini seratnya lurus, mudah dibikin pipih, dan kuat karena ada serat yang melintang (sel jari-jari kayu).

(4). Untuk tanggar (semacam tongkat untuk mendorong jika kandas atau melewati jeram), kayu yang biasa digunakan adalah tema (Memecylon garcindes), tema bala (Memecylon costatum), dan lain-lain. Kayu ini dipilih karena umumnya lurus, panjang, kuat, bulat, dan tahan air.

(5). Untuk menambal perahu apabila terjadi kebocoran, terutama pada sambungan bagian-bagian papannya, digunakan tu'dan (damar) yang berasal dari pohon-pohon yang tumbuh secara liar di hutan (lihat bagian damar di bawah ini). Damar ini ditumbuk lalu dipanaskan sampai cair disebut lisan. Damar cenderung lebih disukai karena damar tidak ditembus oleh air.

\section{Hutan sebagai Sumber Pendapatan Uang Tunai}

\section{a. Pendapatan dari kayu gaharu (Aquilaria spp.) dan kayu manis (Cinnamomum burmanni)}

Gaharu adalah zat ekstraktif berupa resin yang diproduksi oleh jenis kayu tertentu yang berfungsi untuk menangkal serangan hama dan penyakit yang berasal dari luar. Zat ekstraktif ini bersifat racun, sehingga agen perusak kayu (seperti: serangga, bakteri, dan jamur) tidak bisa masuk ke dalam kayu. Di bagian kayu gubal sering terbentuk endapan zat ekstraktif ini, karena bagian kayu tersebut luka ${ }^{7}$ yang disebabkan oleh ranting patah, diserang binatang, atau faktor perusak yang lain. Secara alami zat ekstraktif ini mengendap di bagian dalam kayu teras yang menyebabkan warna kayu menjadi gelap kehitaman. Gaharu (lihat Foto 7) berbau harum yang menyebabkan harganya 
mahal. Gaharu digunakan sebagai dupa dengan harum khas, dipasarkan ke Saudi Arabia, Hong Kong, Singapura, dan tempat lain dengan harga tinggi. Untuk informasi lebih mendalam mengenai keadaan gaharu di hulu Sungai Bahau, lihat Momberg et al. (2000) dan Wollenberg (2001).

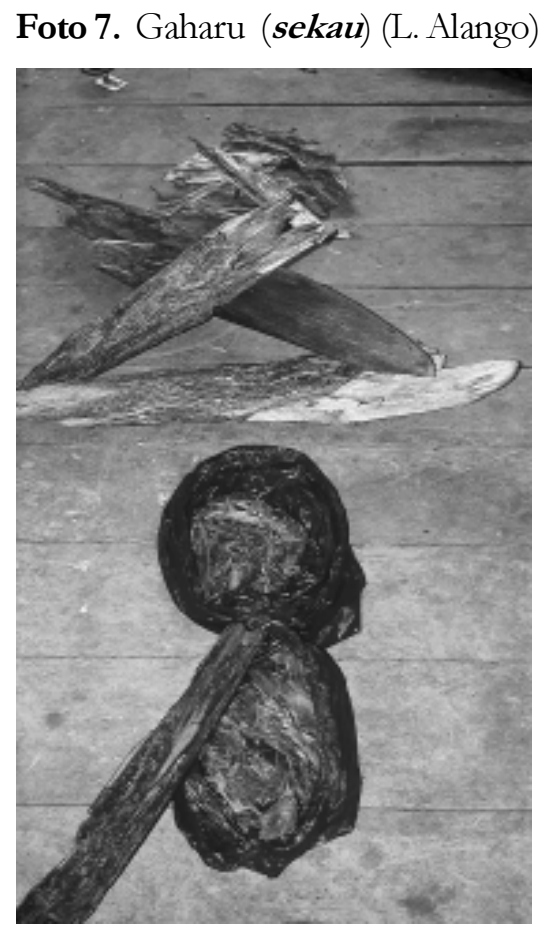

Di daerah Sungai Bahau masyarakat mengenal lima jenis gaharu yang disebut sekau antara lain: sekau mu'dung (Aquilaria malaccensis), sekau buaya (Aquilaria beccariana), sekau nyibung, sekau bai, dan sekau cabut. Gaharu merupakan sumber pendapatan utama untuk memperoleh uang tunai. Berdasarkan hasil penelitian ini ratarata $40 \%$ sampai $81 \%$ rumah tangga per kampung mendapatkan uang tunai dari hasil gaharu. Rumah tangga yang mengandalkan sumber pendapatan dari kayu gaharu tersebut rata-rata memperoleh uang tunai sekitar 56\% sampai $69 \%$ dari rata-rata jumlah pendapatan total. 
Jika dibandingkan dengan sumber pendapatan dari hasil hutan lainnya (misalnya: rotan, kayu manis, ketipai, buah-buahan, dan lainlain), pendapatan dari gaharu mencapai 92\% sampai 100\%. Ini menunjukkan bahwa pendapatan dari hasil kayu gaharu menduduki tempat teratas dibandingkan dengan sumber pendapatan uang tunai lainnya, baik yang berasal dari hutan primer maupun dari hutan sekunder.

Pada saat ini gaharu super dijual seharga 7 juta rupiah per kg. Harga gaharu cenderung terus meningkat sejak tahun 1990 sampai 1999. Namun sebagian masyarakat meramalkan bahwa harga gaharu di suatu saat akan jatuh, sedangkan harga hasil hutan lainnya meningkat.

Selain gaharu, sumber pendapatan yang penting lainnya adalah kayu manis (kayu me: Cinnamomum burmanni) (lihat Foto 8). Harga kayu manis relatif stabil yaitu sekitar 1 - 1,5 ribu rupiah per $\mathrm{kg}$ kalau dijual di kampung. Hasil penelitian ini menunjukkan bahwa pendapatan uang tunai dari hasil penjualan kayu manis hanya terdapat

Foto 8. Kayu manis (kayu me) di L. Alango

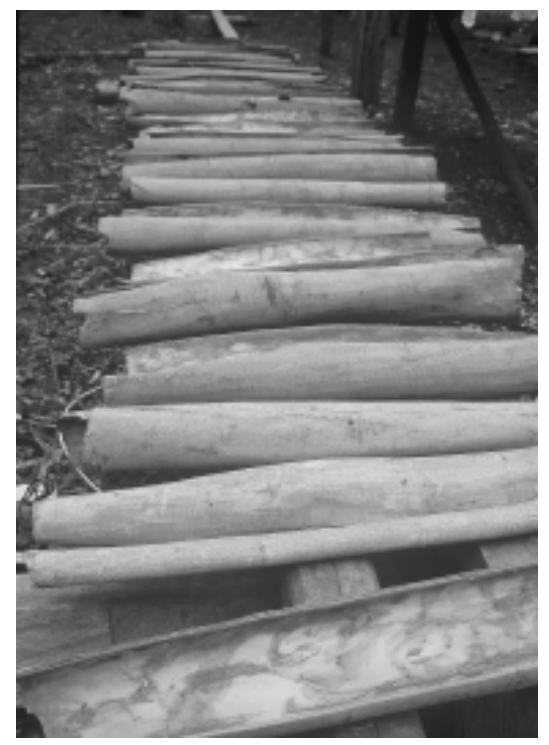


di Apau Ping dan Long Alango, yaitu sekitar satu sampai tujuh keluarga atau sekitar 3\% sampai $22 \%$ dari penduduk per desa. Dibandingkan dengan pendapatan uang tunai dari penjualan hasil hutan lainnya, hasil penjualan kayu manis mencapai 4\%.

\section{b. Pendapatan dari penjualan hasil hutan selain gaharu dan kayu manis}

Selain gaharu dan kayu manis masih ada berbagai hasil hutan yang bisa jadi sumber pendapatan. Hasil hutan dimaksud merupakan pilihan yang dapat saling menggantikan di saat harga salah satu jenis mengalami fluktuasi. Hasil penelitian ini menunjukkan rata-rata 6 sampai 22 rumah tangga, atau sekitar 19\% sampai 55\% rumah tangga per desa mendapatkan uang tunai dari penjualan hasil hutan selain gaharu dan kayu manis.

Pasar hasil hutan selalu berubah pada setiap beberapa tahun. Sejak tahun 1973-85 harga rotan mentah Rp. 125 per kg, kemudian pada tahun 1986-89 naik menjadi Rp. 500 per kg. Mulai tahun 1989 harga rotan menurun sampai jatuh tidak ada harga. Pada tahun 199196 masyarakat tidak ada lagi yang menjual rotan mentah, sebab tidak ada pembeli ${ }^{8}$. Pada tahun 1997-98 harga rotan mulai membaik sekitar 2 - 4 ribu per kg.

Penjualan kayu-kayu bangunan sudah tidak ada sampai sekarang. Pada tahun 1969-73 dan 1989 penjualan kayu-kayu bangunan sangat ramai akibat banjir-kap. Banjir-kap itu adalah istilah yang dipakai di Malinau yang bermaksud penebangan liar. Kayu yang dekat pinggir sungai ditebang secara tidak resmi dan dibawa ke pembelinya lewat sungai. Sekarang masyarakat menjual kayu dalam bentuk barang jadi, misalnya perahu sangat laku dijual walaupun dengan harga tinggi. Demikian juga halnya dengan damar, sudah tidak laku lagi, masyarakat memungut damar untuk kebutuhan sendiri. Getah ketipai (Palaquium quercifolium) masih memiliki harga, tetapi hanya untuk memenuhi pasaran lokal saja, misalnya antar keluarga dalam satu kampung dengan harga jual Rp. 4-5 ribu per batang berdiameter $2 \mathrm{~cm}$ dengan panjang $5 \mathrm{~cm}$. 
Penjualan hasil hutan berupa buah-buahan cenderung meningkat pada tahun-tahun belakangan ini. Harga buah mata kucing (isau bala: Dimocarpus longan ssp. malesianus var. malesianus) meningkat dari Rp. 5.000 per kaleng ( $1 \mathrm{kaleng}=12-13 \mathrm{~kg}$ ) pada tahun 1986 menjadi Rp. 7.000 per kaleng tahun 1987 (lihat juga Puri 1998). Pada tahun 1998 meningkat tajam mencapai Rp. 18.000 per kaleng. Jadi selama tiga tahun ini harga buah mata kucing rata-rata meningkat 98,5\% per tahun. Keadaan ini sangat dipengaruhi oleh keadaan perekonomian dalam negeri terutama gejolak moneter, pangsa pasar, dan kelancaran transportasi dari hulu ke hilir. Buah-buahan yang lain juga mengikuti perkembangan harga yang baik, seperti: dian da'un (Durio oxleyanus), dian kalang (Durio zibethinus), bua' a'bung (Nephelium ramboutan-ake), bua' sanggit (Nephelium lappaceum), bua' unjing (Nephelium maingayi), berenyiu (Mangifera caesia), mangga (Mangifera indica), alim (Mangifera pajang), nakan (Artocarpus integer), kian (Artocarpus odoratissimus), basut (Artocarpus lanceifolius), bitung (Garinia mangostana), dan langset (Lansium domesticum).

Telah disebutkan di atas bahwa buah-buahan ini masih banyak dipanen dari hutan liar, yaitu sekitar 17\% sampai 38\%. Masyarakat akan tetap dapat memanen hasil secara berlanjut hanya kalau hutan masih bagus. Pemanenan buah-buahan ini tanpa menimbulkan kerusakan terhadap hutan. Cara memanen yang baik memungkinkan untuk bisa menjual hasilnya setiap tahun. Ini sangat berbeda jika dibandingkan dengan penjualan dari penebangan kayu, yang dampaknya sangat merusak apabila dilakukan dalam sekala luas.

\section{c. Penjualan hasil hutan berupa barang-barang hasil olahan}

Barang-barang hasil olahan dijual untuk menghasilkan uang tunai. Jenis-jenis barang olahan yang umum dijual adalah tikar, topi, dan tas rotan (dalam penelitian ini hasil penjualan barang olahan digabung dengan penjualan arak). Hasil penelitian ini menunjukkan rata-rata 16 sampai 18 rumah tangga, atau berkisar antara 38\% sampai 52\% rumah tangga per kampung mendapatkan penghasilan uang tunai dari penjualan barang-barang olahan pada tahun 1995-96. Pada 
perkembangan belakangan ini semakin banyak barang-barang olahan yang dapat dijual, antara lain: sumpit, sambe', ki'ba, ingen, tapan, dan lain-lain. Barang-barang ini sumber bahan bakunya berasal dari tumbuhan yang tumbuh liar di hutan.

Penjualan hasil hutan berupa barang-barang olahan dalam bentuk kerajinan dapat meningkatkan nilai tambah jika dibandingkan dengan penjualan langsung dalam keadaan mentah. Selain masyarakat mendapat hasil penjualan yang lebih tinggi, persediaan bahan baku juga dapat dihemat. Apabila menjual rotan mentah secara langsung, harganya murah dan perlu banyak rotan yang dijual. Sehingga sangat cepat menghabiskan persediaan sumber bahan baku di hutan. Sebagai contoh, satu belanyat (semacam tas dari rotan) ukuran sedang dibuat dari 45 - 50 batang ${ }^{9}$ rotan sega (Calamus caesius) dengan panjang 4 $5 \mathrm{~m}$ atau kurang lebih 1 gelung yaitu sekitar $4 \mathrm{~kg}$. Belanyat ini bisa dijual seharga 30 - 40 ribu rupiah pada tahun 1998. Sedangkan $1 \mathrm{~kg}$ rotan sega dijual kepada pedagang sekitar 2 - 4 ribu rupiah per kg. Orang yang membuat belanyat mendapat keuntungan senilai 14 32 ribu rupiah per belanyat atau sekitar 3,5 - 8 ribu rupiah per $\mathrm{kg}$ rotan sega. Besarnya keuntungan tergantung keahlian orang yang membuat belanyat tersebut, orang yang sudah mahir menganyam rotan mampu membuat belanyat yang berasal dari rotan yang berkualitas rendah (harga murah) menjadi sebuah belanyat yang bagus dengan harga mahal.

\section{Hutan sebagai Sumber Bahan Baku untuk Perlengkapan Kebutuhan Sehari-hari}

Orang Dayak dalam kehidupan sehari-hari banyak membutuhkan perlengkapan hidup, antara lain untuk memasak dan mengolah makanan, untuk membantu dalam mencari nafkah, untuk meringankan beban kerja, dan melindungi diri dari alam. Dalam tulisan ini yang dikelompokkan dalam perlengkapan kebutuhan sehari-hari meliputi: kayu bakar, getah parang, damar, sumpit, ki'ba, topi, tikar, tali, daun pembungkus, dan daun untuk atap. Barang-barang ini dibuat dari bahan-bahan yang diperoleh dari hutan. 
Foto 9. Mengumpulkan kayu api di Apau Ping

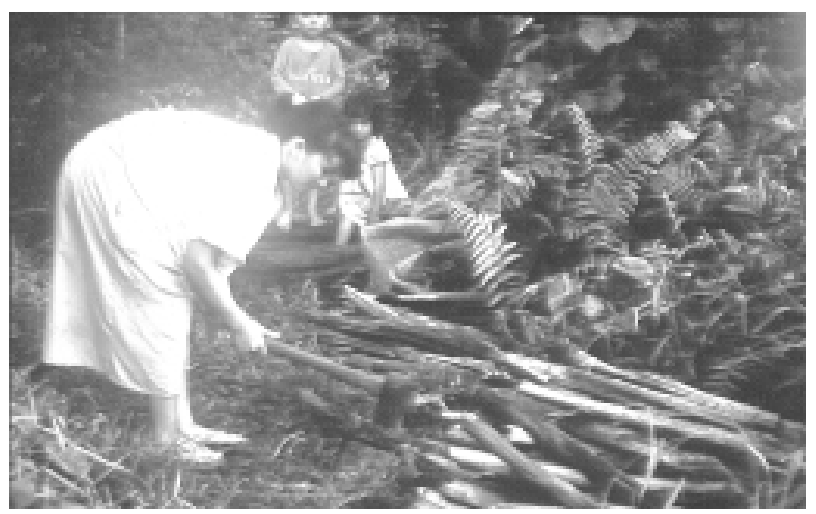

\section{a. Hutan merupakan sumber untuk memperoleh kayu bakar}

Pada umumnya orang Dayak di sekitar TN Kayan Mentarang menggunakan kayu bakar untuk keperluan memasak sehari-hari (lihat Foto 9a dan 9b). Hampir semua jenis kayu dapat digunakan sebagai kayu bakar. Kayu-kayu ini dapat diperoleh dengan mudah di hutan, baik di hutan rimba maupun di hutan-hutan sekunder muda bekas perladangan. Hasil penelitian ini menunjukkan bahwa ada beberapa jenis kayu tertentu yang paling disukai dan paling banyak dipakai sebagai kayu api di daerah Sungai Bahau. Jenis kayu api yang paling disukai antara lain: kayu japa'(Vitex pinnata), bine (Macaranga sp.), bela'ban (Tristaniopsis whiteana), palan (Lithocarpus spp.) dan lain-lain. Alasan dipilihnya kayu-kayu ini karena bagus dimakan api (mudah terbakar), mudah kering, dan tidak jauh dari rumah. Kebanyakan jenis kayu yang disukai oleh orang setempat untuk kayu api ada di jekkau (hutan sekunder bekas ladang).

Kayu yang bagus dimakan api adalah kayu keras (umumnya berat). Kayu yang disebutkan di atas adalah kayu keras kecuali kayu bine yang agak lemah. Kayu tersebut dipakai karena mudah didapat di hutan-hutan sekunder bekas ladang. Batang kayu yang masih kecil mudah dipotong memakai kapak sehingga tidak perlu tenaga banyak. Kayu ini pada umumnya mudah diangkut karena ladang dekat dengan rumah. Kayu-kayu besar walaupun lebih dekat, misalnya penjae 
(=laran ba'bui: Hopea mengerawan) tidak digunakan sebagai kayu api. Kayu yang besar sulit ditebang dan dipotong karena harus menggunakan gergaji rantai (chainsaw) dan lebih sulit untuk dibelahbelah karena besar.

Pada saat orang perlu menginap di hutan karena keperluan mencari hasil hutan atau berpergian jauh, mereka harus memasak di dalam hutan. Kayu api yang paling disukai di dalam hutan adalah kayu palan (Lithocarpus spp.), karena kayu ini mudah ditebang, mudah dibelah karena seratnya lurus, mudah kering karena pori kayu ini besarbesar, dan mengandung resin yang mudah dimakan api. Dalam keadaan segar (mentah), apabila kayu ini diraut halus bisa menyala oleh api kecil. Sedangkan potongan kayu palan lainnya yang sudah dibelah sebesar tiga jari, dapat kering dalam tempo setengah jam dan mudah menyala.

Orang Dayak selain membutuhkan kayu bakar untuk memasak, mereka juga perlu kayu bakar untuk menghangatkan badan yang disebut mendu (berdiang), terutama untuk anak kecil, pada musim hujan, dan apabila berada di dalam hutan. Jika berada di rumah mereka sering membakar kayu di bawah kolong untuk mengusir nyamuk dan untuk berdiang bagi anjing peliharaan. Kayu bakar juga dipakai untuk memasak makanan anjing, yaitu ubi yang biasanya harus direbus lama.

\section{b. Di hutan diperoleh getah parang ketipai (Palaquium quercifolium) untuk kebutuhan sehari-hari}

Semua orang Dayak di sekitar TN Kayan Mentarang membutuhkan parang untuk kehidupan sehari-hari, baik orang perempuan maupun laki-laki. Getah ketipai (Palaquium quercifolium) digunakan untuk merekatkan parang dengan tangkainya. Parang digunakan sebagai perlengkapan hidup untuk mencari nafkah dan perlindungan diri. Setiap pergi masuk hutan atau ke ladang mereka pasti membawa parang. Parang juga sangat berguna di dapur untuk membersihkan ikan, memotong daging dan kayu api. 
Getah ketipai diperoleh dari tumbuhan yang tumbuh liar di hutan. Selain getah ketipai ada sejenis getah lainnya yang berasal dari getah liana yang disebut aka plutan (Willughbeia sp.), yang bisa dipakai untuk getah parang. Getah plutan ini dipakai apabila ketipai sulit ditemukan. Jadi keduanya bisa saling menggantikan.

\section{c. Di hutan diperoleh tumbuh-tumbuhan untuk membuat sumpit}

Sumpit merupakan alat untuk berburu khas bagi orang Dayak. Sumpit terdiri dari beberapa bagian yaitu: (1) Buluh sumpit terbuat dari kayu yang dilubangi di bagian dalamnya. Kayu yang paling disukai untuk membuat sumpit adalah kayu bitung (Garinia mangostana), belien (=ulin: Eusideroxylon wwageri), dan kayu balet (Dipterocarpaceae). (2) Langan (anak sumpit sebesar lidi) terbuat dari kulit pelepah daun talang (Arenga undulatifolia). Langan ada dua macam yaitu langan lat dan langan bela'dang. Langan lat adalah anak sumpit biasa tanpa besi atau logam. Sedangkan langan bela'dang di ujungnya ada besi atau logam berbentuk segitiga. (3) Piping (pendorong) anak panah bagian belakang terbuat dari bagian dalam pelepah daun nanga (Eugeissona utilis) yang mirip seperti gabus, ringan didorong oleh tenaga angin. (4) Salo atau ipo'adalah racun sumpit yang dioleskan di ujung anak sumpit tersebut. Salo atau ipo' merupakan racun yang sangat kuat untuk binatang maupun bagi manusia. Racun ini berupa getah yang diambil dari pohon salo (=kayu ipo': Antiaris toxicaria) yang berasal dari tumbuhan liar di hutan. Selain racun yang berasal dari tumbuhan ada juga yang menggunakan racun yang berasal dari bisa ular yaitu sejenis ular cobra yang sangat berbisa, antara lain njau liban (= cobra coklat. Ophiophagus hannah) dan buah (= cobra hitam. Naja sumatrana).

Penggunaan sumpit dan racun untuk berburu binatang nampaknya ada kecenderungan mulai berkurang untuk generasi sekarang. Kebanyakan orang muda sekarang lebih senang menggunakan senapan buatan sendiri, karena lebih mudah memperoleh binatang. Ada juga beberapa keluarga yang masih mempertahankan cara berburu dengan menggunakan anjing dan 
bujak (lihat Foto 10), terutama kampung-kampung yang terletak di hulu, karena harga peluru sekarang sangat mahal. Peluru sulit didapat dari Malaysia karena petugas lebih tegas. Ada kemungkinan di masa yang akan datang berburu dengan anjing, sumpit, dan bujak akan meningkat sebab mahalnya peluru.

Foto 10. Orang yang siap berburu dengan bujak sambil pergi ke ladang (Apau Ping)

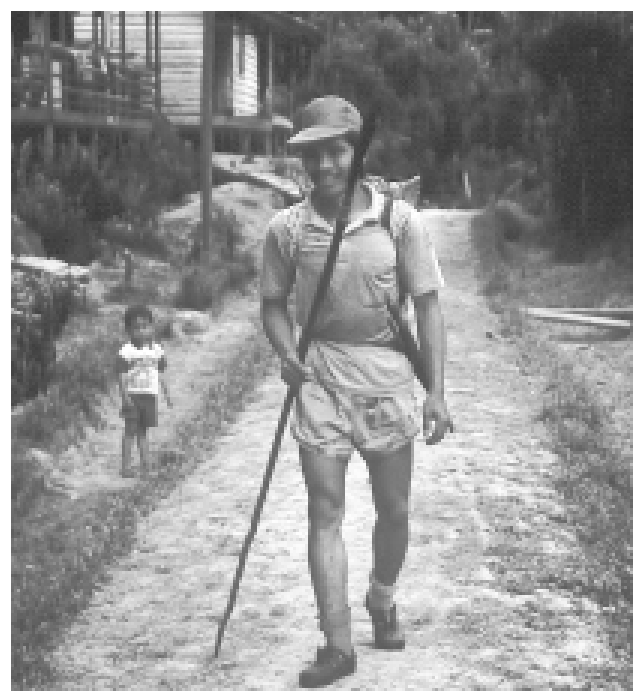

\section{d. Di hutan diperoleh bambu dan rotan untuk membuat alat- alat perlengkapan kerja}

Bambu dan rotan banyak dimanfaatkan untuk membuat alat-alat perlengkapan kerja seperti alat untuk menggendong barang seharihari, alat menggendong padi, menangkap ikan, membersihkan beras, tikar untuk alas tidur, alas menjemur padi, serta barang-barang kerajinan misalnya topi untuk perhiasan dan kebudayaan. Jenis-jenis bambu yang paling banyak digunakan adalah bulo lung (Dendrocalamus asper), bulo latung (Schizostachyum brachycladum), bulo lan (Schizostachyum latifolium), bulo panyut bileng (Bambusa inlgaris), bulo panyut bila' (Bambusa vulgaris cl. vittata) dan bulo pusa 
(Schizostachyum sp.). Jenis-jenis rotan adalah uwai seka (Calamus caesius) (lihat Foto 11), uwai tebungen (Calamus ornatus), uwai balamata (Calamus sp1.), uwai seringan (Daemonorops hallierianus), uwai semule' (Daemonorops periacanthus). Jumlah jenis bambu dan rotan yang dipanen per rumah tangga per desa ada 6 sampai 9 jenis. Dari jenis-jenis tersebut 95\% sampai 99\% dipanen dari hutan liar.

Orang Dayak lebih suka menggendong barangnya pada saat membawa dalam perjalanan, baik pada waktu mengangkut barang dari ladang maupun dari hutan atau sewaktu bepergian. Alat-alat yang biasa digunakan untuk menggendong barang adalah: ki'ba, ingen, belanyat beta, dan belanyat kalung. Ki'ba adalah semacam tas ransel terbuat dari rotan, berlobang besar-besar seperti keranjang berbentuk segi empat dan sangat elastis. Ingen adalah alat khusus untuk menggendong padi yang bentuknya juga segi empat terbuat dari bambu dianyam rapat tidak ada lobang. Ingen kurang elastis dibanding ki'ba. Belanyat beta adalah tas seperti keranjang kecil

Foto 11. Pengumpulan uwai seka (rotan sega) di hutan (Apau Ping)

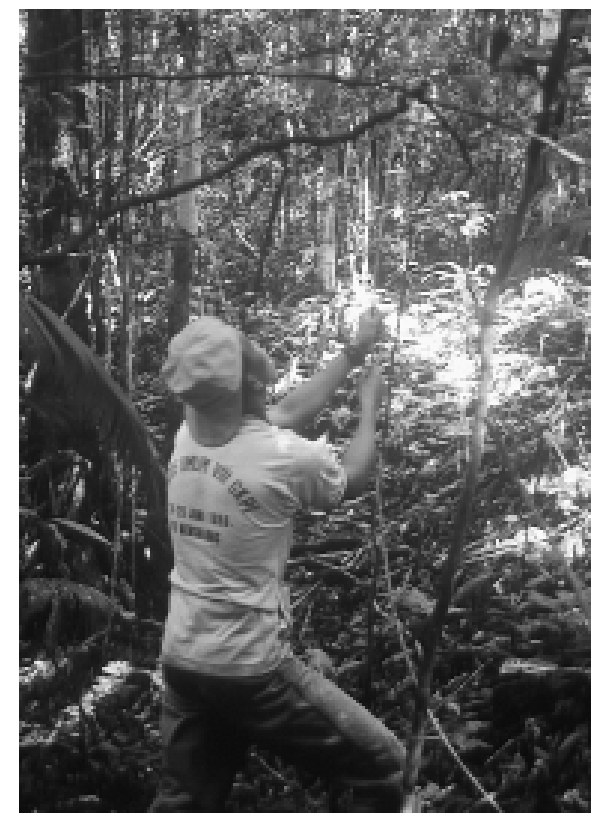


dengan banyak lubang. Belanyat beta umumnya dipakai untuk membawa ikan pada saat menjala, dan juga sering dipakai untuk membawa bekal ketika masuk hutan atau ke ladang. Pada jaman dulu belanyat beta dipakai khusus untuk upacara yang disebut melaki. ${ }^{10}$ Sedangkan belanyat kalung adalah tas indah yang bentuknya bulat ukurannya bervariasi dari kecil sampai besar (lihat Foto 12). Anyaman belanyat kalung ini memiliki corak ukiran khas Dayak dengan berbagai motif tertentu. Belanyat kalung hanya dibuat dari rotan yaitu uwai seka, sedangkan ki'ba dan belanyat beta dapat dibuat dari jenis rotan lain. Dalam kehidupan sehari-hari ki'ba dan belanyat beta lebih banyak digunakan untuk menggendong barang dan fungsinya lebih serbaguna, ingen umumnya hanya untuk menggendong padi. Sedangkan belanyat kalung hanya dipakai untuk bepergian ke tempat-tempat umum, tempat keramaian, atau ke pesta. Belanyat kalung sering diperjualbelikan secara lokal dan bahkan sampai ke luar pulau. Ada juga yang menggunakan belanyat kalung sebagai cenderamata.

Foto 12. Tiga contoh belanyat dari hulu Bahau

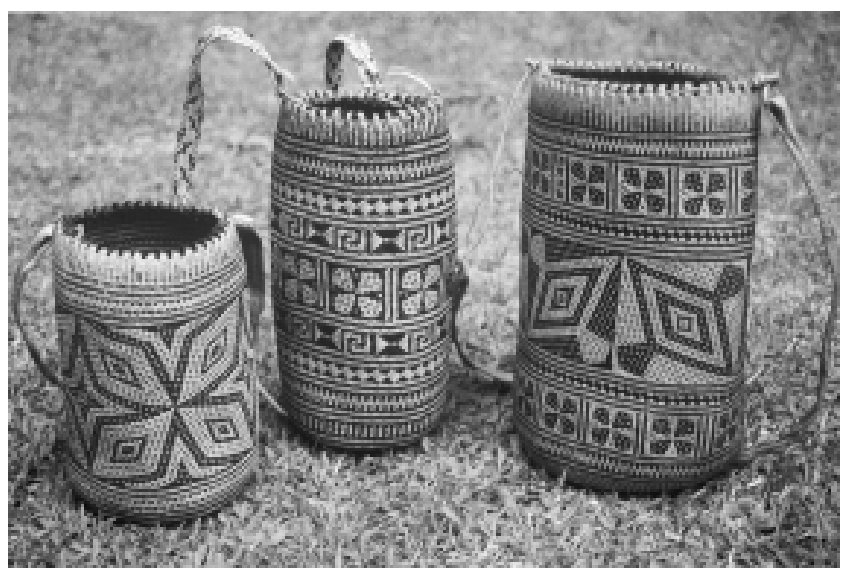

Alat lain yang dibuat dari bambu atau rotan adalah bubu, bading, kebang, tapan, terayung, taing, pat, saung seling, dan kerajinan lainnya. Bubu dan bading adalah alat untuk menangkap 
ikan di sungai berupa perangkap yang bentuknya bulat seperti botol tetapi ukurannya besar dengan panjang $1 \mathrm{~m}$. Kebangadalah alat untuk menumbuk bumbu dan sambal yang bentuknya seperti lesung, dibuat dari seruas bambu yang dipotong ujungnya dan dibiarkan satu bukunya. Bambu yang dipakai adalah bulo lung karena ruasnya kuat. Pasangannya adalah tun (=alu) yaitu alat untuk menumbuknya. Tapan adalah alat untuk membersihkan beras dari kotoran berupa sekam padi yang masih tersisa, atau biji padi yang belum terkupas, dan kotoran lain yang terikut. Beras diletakkan di atas tapan kemudian digoyang dan digetar-getarkan atau diayun-ayunkan sehingga kotorannya keluar. Terayung adalah anyaman dari bambu yang bentuknya lebar, ukurannya 0,5 x $1 \mathrm{~m}$ dipakai untuk alas barang di dalam ki'ba supaya barang-barang yang ukurannya kecil tidak jatuh. Terayung dibuat dari bulo pusa. Taing adalah tikar yang ukurannya relatif besar umumnya $5 \times 10$ m anyamannya agak kasar dipakai untuk alas menjemur padi atau sebagai karpet lantai di dalam rumah. Taing dibuat dari uwai semule'atau uwai seringan. Pat adalah tikar untuk alas tidur yang sangat halus dengan motif hitam puth yang indah. Gambar di dalamnya menunjukkan corak khas Dayak. Pat dibuat hanya dari uwai seka. Saung seling adalah topi yang berukuran lebar terbuat dari bambu juga dengan corak yang khas berisi lukisan tertentu lambang bangsawan (lihat Foto 13). Jenis bambu yang dipakai untuk saung seling adalah bulo panyut bila' atau bulo panyut bileng: Saung seling hanya dimiliki oleh orang tertentu keturunan bangsawan. Selanjutnya akan dibahas dalam bagian kebudayaan.

\section{e. Tali dan bahan pengikat}

Hampir setiap perlengkapan yang telah disebutkan di atas membutuhkan tali untuk mengikat. Begitu pula dalam kegiatan seharihari, sering kali ada keperluan untuk mengikat barang-barang. Hasil penelitian ini menunjukkan bahwa ada empat sampai delapan jenis tali dan bahan pengikat yang dibutuhkan per rumah tangga per desa. Dari jenis tersebut $88 \%$ sampai $96 \%$ diperoleh dari tumbuhan liar di hutan. 
Foto 13. Topi saung seling dan persediaan untuk anyaman (Apau Ping)

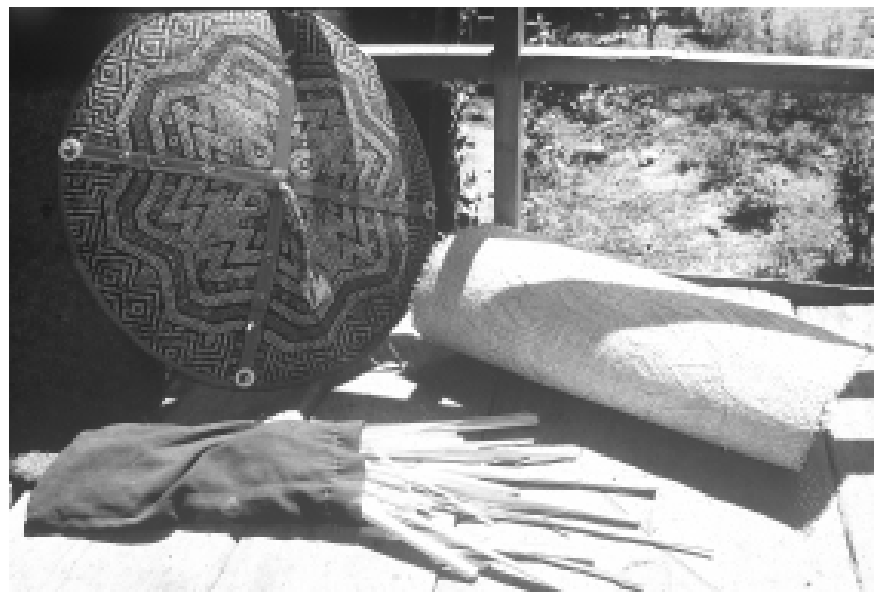

Berdasarkan hasil wawancara, masyarakat di sekitar TN Kayan Mentarang membedakan tali dengan bahan pengikat. Tali dan bahan pengikat dapat berfungsi sama yaitu untuk mengikat sesuatu dalam kegiatan sehari-hari. Tali lebih cenderung dikategorikan sebagai alat yang sudah jadi melalui proses pengolahan bahan baku tertentu, umumnya lebih kuat, lebih indah, dan lebih tahan lama. Sehingga tali ini dipakai untuk keperluan jangka panjang dan dapat dipakai di tempat umum. Jenis-jenis tali yang dimaksud ada dua macam yaitu tali te' bala dan tali te' pute'(te'= kulit kayu). Dalam penggunaan sehari-hari kedua jenis tali ini digunakan pada alat-alat sebagai berikut: tali ki'ba (tali untuk alat gendongan ke ladang atau ke hutan), tali belanyat (tali untuk sejenis tas yang indah terbuat dari rotan), tali ingen (tali yang dipakai pada alat menggendong padi), tali sikep (tali yang dipakai pada alat untuk menangkap ikan), tali ba' (tali yang dipakai pada alat untuk menggendong bayi), tali saung (tali yang dipakai pada sejenis topi yang lebar diikat di kepala agar tidak lepas diterbangkan angin), tali biru (tali untuk membuat jerat), dan lain-lain. Bahan tali ini berasal dari serat kulit kayu yang pohonnya tumbuh liar di hutan antara lain: talun (=dengeng. 
Artocarpus elasticus) menghasilkan tali te' bala, dan kayu te' (Goniothalamus sp.) menghasilkan tali te' pute'.

Sedangkan sebutan bahan pengikat dipakai untuk jenis bahan yang dipakai langsung tanpa diolah, misalnya lemba' (Musa sp.) diambil pucuk yang muda dibelah-belah lalu dikeringkan kemudian dipakai untuk menjahit saung sang (topi). Lidi daun sang (Licuala valida) yang masih muda dipakai untuk mengikat atap yang terbuat dari daun. Jenis-jenis rotan adalah yang paling banyak dipakai, contohnya uwai seka (Calamus caesius), uwai tebungen (Calamus ornatus), uwai semule (Calamus sp.), uwai seringan (Calamus sp.). Bahan pengikat lainnya adalah jenis liana yang disebut dengan nama aka (liana), misalnya aka te' ayang (Bauhinia semibifida), aka tat (= akar berduri: belum diidentifikasi), aka kelesei (Spatholobus ferrugineus), aka kelesei atuk (Spatholobus sp.), aka padem (Meremia sp.), aka kepun (Rhizanthes sp.), dan lain-lain. Semua jenis liana ini dipanen dari yang tumbuh liar di hutan. Liana yang tumbuh di bekas ladang jarang digunakan karena kebanyakan bahan pengikat ini dibutuhkan pada saat kegiatan di hutan. Bahan pengikat ini biasanya digunakan untuk mengikat pondok apabila bermalam di hutan sehingga membutuhkan bahan yang praktis. Selain itu biasa juga dibutuhkan untuk mengikat binatang buruan, misalnya babi diikat dengan tali lalu dihanyutkan di sungai, sekali-sekali ditarik apabila tersangkut.

\section{f. Daun untuk pembungkus makanan, atap dan kerajinan}

Hasil penelitian ini menunjukkan bahwa setiap rumah tangga di sekitar TN Kayan Mentarang menggunakan 6 sampai 11 jenis daun per rumah tangga per kampung. Dari jenis-jenis daun tersebut $48 \%$ sampai 67\% dipanen dari hutan liar dalam waktu satu tahun 199596. Sebagian daun ada yang dipanen dari hasil yang ditanam di kebun. Daun-daun tersebut dimanfaatkan untuk berbagai keperluan dalam kehidupan sehari-hari.

Kebiasaan hidup masyarakat sehari-hari suka makan nasi lembek yang disebut ma'lema'(lihat Foto 14) atau Iuba' laya (atau kalau nasi dicampur dengan talas disebut ma' upa'), baik untuk 
Foto 14. Membuat ma' lema'di Apau Ping

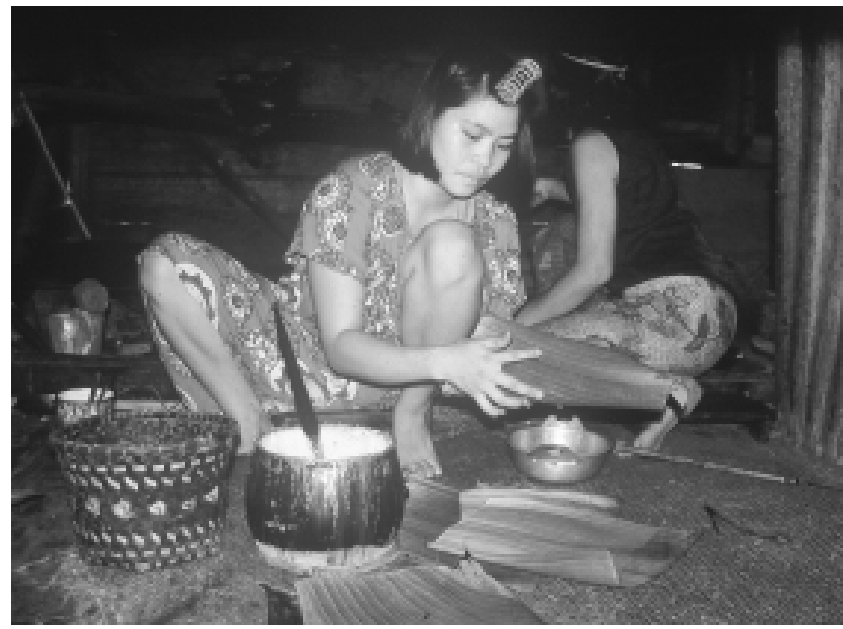

dimakan di rumah maupun untuk bekal ke ladang atau ke hutan. Nasi lembek ini biasanya dibungkus dengan daun. Kebiasaan ini lebih sering ditemukan pada saat ada upacara atau pesta. Selain untuk bungkus nasi, kue-kue yang disebut saga juga dibungkus dengan daun. Daun-daun yang biasa digunakan adalah daun njuk (Maranta arundinacea), daun dalui (Halopegia blumei), daun nyanding (Etlingera elatior), daun pedek (Macaranga triloba), daun kayu kubung (Macaranga gigantea), daun utai (Musaspp.), daun sang (Licuala valida), dan lain-lain.

Selain daun untuk pembungkus ada juga daun yang digunakan untuk atap, terutama di pondok di ladang. Daun-daun ini biasanya dirakit sedemikian rupa, ditusuk dengan tali yang nampaknya seperti dijahit sehingga rapi dan tidak bocor. Ada beberapa jenis daun yang telah disebutkan di atas juga dapat digunakan sebagai atap, seperti: sang dan daun dalui. Jenis daun yang juga baik digunakan adalah daun birai (Salacia affinis var. borneensis), daun kian (Artocarpus odoratissimus), dan daun jaunglan (Zingiber sp.).

Ada beberapa jenis daun yang digunakan untuk bahan kerajinan tangan. Daun-daun tersebut antara lain: daun da'a (Pandanus cf. Kaida) untuk tapung da'a (topi), daun sang (Licuala valida) (lihat 
Foto 15) untuk saung (sejenis topi yang lebar yang dipakai pada saat bekerja di ladang untuk pelindung panas) (lihat Foto 16). Jenis-jenis kerajinan dibahas lebih lanjut dalam bahasan kebudayaan.

Semua jenis daun yang disebutkan di atas ditemukan di hutan liar. Ada kecenderungan sekarang masyarakat menanam di pula (kebun) antara lain: daun dalui (Halopegia blumei) dan daun da'a (Pandanus if. kaida) ditanam hanya untuk kepentingan daunnya saja, daun nyanding (Etlingera elatior) ditanam untuk diambil umbut, bunga, buah, dan daunnya, kian (Artocarpus odoratissimus) untuk diambil daun dan buahnya, dan peti (Musa paradisiaca) untuk diambil daun, bunga, dan buahnya.

Foto 15. Ragi disimpan dalam daun sang dengan bawing sebagai pengawet

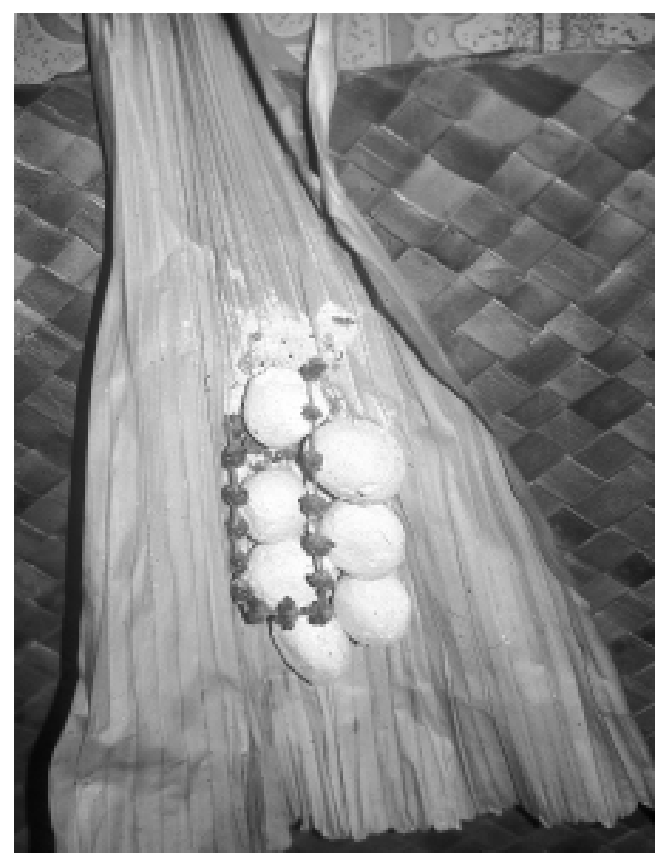


Foto 16. Ibu-ibu memakai saung sambil cari ikan di L. Alango

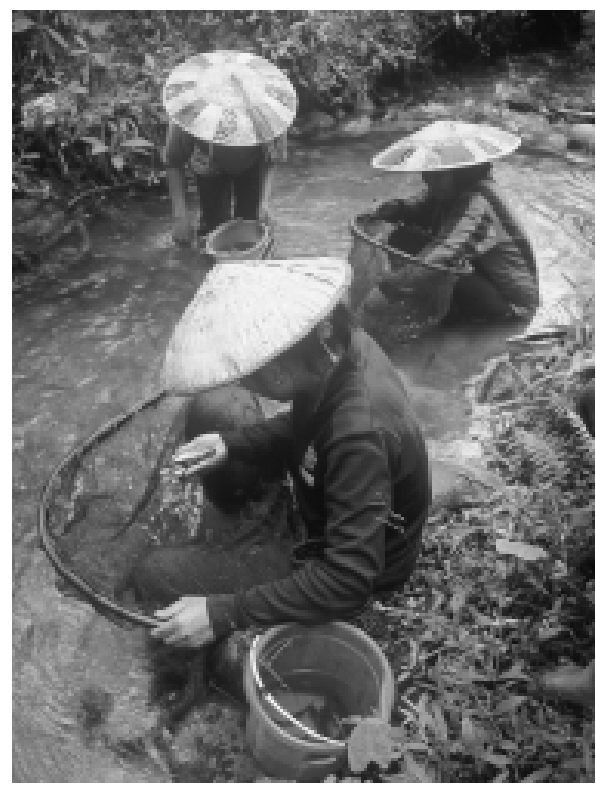

\section{g. Damar untuk dempul perahu dan penerangan pengganti minyak tanah}

Damar atau resin disebut tu'dan merupakan zat ekstraktif yang mengeras berbentuk padat yang berasal dari berbagai jenis tumbuhan di dalam hutan. Damar ini dapat mencair apabila dipanaskan dan bersifat sebagai perekat yang dapat menyatu dengan kayu, kemudian mengeras lagi setelah dingin. Sifat damar seperti ini baik untuk mendempul perahu. Mula-mula damar ini ditumbuk halus lalu dipanaskan sehingga mencair seperti lem yang disebut lisan. Untuk menambal perahu apabila ada kebocoran, terutama pada sambungan bagian-bagian papannya, damar cenderung lebih disukai karena damar tidak tembus air (lihat Foto 17).

Selain itu damar juga dapat dimanfaatkan untuk penerangan apabila menginap di hutan. Damar penting sebagai barang substitusi di masa krisis ekonomi seperti sekarang ini, dan juga penting waktu terjadi kemarau panjang di mana harga minyak tanah melambung 
tinggi dan kadang-kadang persediaan tidak ada. Khususnya untuk orang yang tinggal lama di dalam hutan. Sebagai contoh berdasarkan pengamatan dan pengalaman bersama orang Dayak di hutan. Orang yang mencari gaharu menebang pohonnya yang dilakukan siang hari kemudian dipotong kecil-kecil. Bagian batang yang ada isinya dibawa ke pondok. Sampai di pondok, di malam hari mereka membersihkan gaharu tersebut dengan menggunakan damar sebagai penerangan. Gaharu dibersihkan dengan cara meraut dengan pisau kecil. Hanya gaharu yang bersih yang mereka bawa pulang, sehingga tidak perlu menggendong kotoran yang berat. Untuk bekerja di hutan orang lebih cenderung menggunakan damar sebagai lampu, sebab tidak harus menggendong minyak yang berat dari rumah dan dapat lebih hemat dari segi uang untuk beli minyak. Pada waktu hujan, apabila kayu api banyak yang basah, maka damar inilah sebagai penyulut yang pertama. Setelah damar menyala cukup besar baru kemudian kayunya bisa terbakar.

Masyarakat yang membutuhkan damar dapat mengambil di dalam hutan yang dihasilkan dari beberapa jenis tumbuhan. Ratarata per keluarga memperoleh damar yang berasal dari tiga sampai lima jenis tumbuhan, di mana tumbuhan penghasil damar tersebut

Foto 17. Menambal perahu dengan damar (tu'dan) di Apau Ping
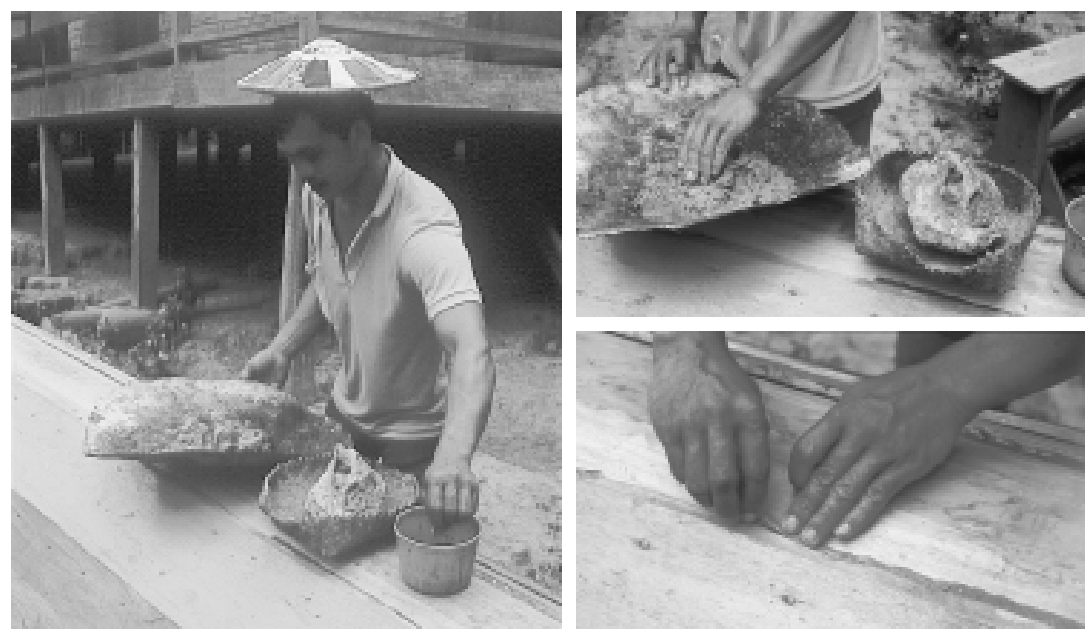
$100 \%$ berasal dari hutan rimba. Kayu-kayu penghasil damar adalah kayu tumu (Agathis borneensis), dan hampir semua jenis dari famili Dipterocarpaceae terutama kayu kapun (Dryobalanops lanceolata), penjae (Hopea mengerawan), dan lain-lain. Keperluan terhadap damar ini hanya sedikit saja. Setiap keluarga membutuhkan sekitar 1\% sampai 5\% saja dari seluruh kebutuhan yang lain.

\section{B. HUTAN MERUPAKAN KEBUTUHAN MASYARAKAT DAYAK SECARA LANGSUNG DAN TIDAK LANGSUNG}

Secara langsung ataupun tak langsung masyarakat Dayak di sekitar TN Kayan Mentarang membutuhkan hutan untuk memulihkan kesuburan tanah. Hutan juga dibutuhkan secara tidak langsung untuk perlindungan sumber air. Selain itu ada masyarakat yang secara langsung ataupun tak langsung mengambil bibit tumbuhan untuk ditanam di kebun. Anak babi hutan untuk bibit ternak juga ada yang ditangkap di hutan.

\section{Ketergantungan Masyarakat Dayak terhadap Hutan untuk Memulihkan Kesuburan Tanah}

Sebagian lahan hutan yang berada dalam wilayah desa difungsikan untuk membuat ladang untuk menanam padi. Ladang dalam bahasa Dayak Kenyah disebut uma'(lihat Foto 18). Sistem perladangan ini dilakukan secara gilir balik, berpindah dari lokasi satu ke lokasi lainnya untuk mendapatkan tanah yang subur, kemudian ke lokasi semula apabila lokasi tersebut sudah kembali kesuburannya. Tanah yang sudah digarap dengan ditanami beberapa jenis tanaman berkurang kesuburannya. Tanah ini kemudian ditinggalkan beberapa tahun (ratarata 6 sampai 15 tahun) untuk mengembalikan kesuburannya. Tanah yang telah berkurang kesuburannya ini dibiarkan menjadi hutan agar subur kembali. Hal ini membuat masyarakat Dayak tidak harus memupuk. Pembakaran daun-daun dan ranting pada saat penyiapan 
lahan dapat memperbaiki kualitas lahan dengan meningkatkan kesuburan tanah. Abu sisa pembakaran menambah kesuburan dengan pengembalian mineral yang berasal dari daun dan ranting. Daun dan ranting yang sulit dibusukkan oleh bakteri dan jamur dapat dipercepat melalui pembakaran. Sedangkan panas yang timbul dari pembakaran dapat merubah sifat fisik dan kimia tanah di permukaan.

Foto 18. Ladang (uma) di L. Tebulo

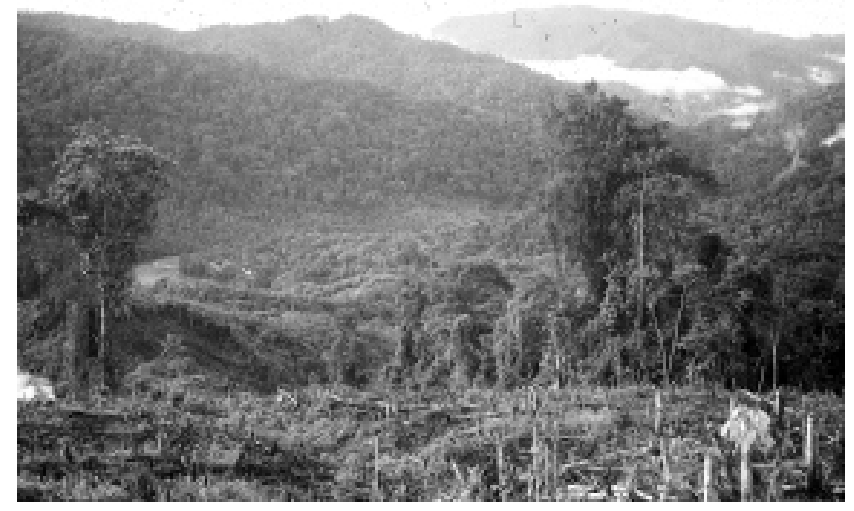

Suatu areal lahan biasanya dikerjakan selama dua sampai lima tahun. Pada tahun pertama ditanami padi, tahun kedua ditanami jagung, kacang-kacangan, dan sayuran, tahun ketiga ditanami singkong, pepaya, pisang, tebu, dan lain-lain. Pada tahun ke empat sampai tahun ke lima biasanya pisang, pepaya dan tebu masih ada, walaupun sudah mulai tumbuh semak di sekitarnya. Tahun berikutnya semak belukar semakin besar tumbuh menjadi hutan sekunder muda. Pada saat ini masyarakat sudah mulai meninggalkannya karena sudah disibukkan oleh kegiatan berladang di tempat lain. Biasanya bekas ladang ini sulit diurus, karena jaraknya yang jauh dari rumah dan berjauhan lokasinya dengan ladang baru.

Ada juga kebiasaan masyarakat yang suka berkebun. Selama memelihara tanaman semusim, mereka menanam tanaman keras seperti beberapa jenis buah-buahan. Akhirnya lahan ini menjadi kebun 
jangka panjang yang disebut pula. Umumnya pula ini dekat dengan kampung. Dalam keadaan tertentu orang Dayak berpindah kampung karena suatu alasan, maka bekas kampung yang disebut lepu' un ini dicirikan oleh adanya kebun buah. Lama-kelamaan lepu'un ini menjadi hutan sekunder yang didominasi oleh pohon buah-buahan.

Jangka waktu yang dibutuhkan untuk memulihkan kesuburan tanah bukan menunggu sampai hutan menjadi dewasa, melainkan hanya beberapa tahun sampai belasan tahun saja sudah digarap lagi. Alasannya karena tanah pada hutan sekunder muda lebih subur dan lebih mudah dikerjakan sebab tidak perlu menebang hutan rimba dengan pohon kayu yang besar-besar. Ladang yang hasilnya baik menandakan bahwa tanah di situ bagus, oleh sebab itu ada kecenderungan lokasi itu akan lebih sering dibuka. Lokasi ini dapat dibuat ladang lagi pada tahun berikutnya, biasanya hanya diulang dua kali saja baru dibuat kebun. Lokasi yang baik ini diolah lagi setelah jekkaunya berumur enam sampai tujuh tahun. Ladang yang biasabiasa saja dapat dikerjakan lagi setelah jekkaunya berumur 15 tahun. Sedangkan ladang yang tidak baik, atau yang gagal panen umumnya tidak diolah lagi. Dibandingkan dengan hasil penelitian lain, Colfer et al. 1997 mengemukakan bahwa jangka waktu yang dibutuhkan selama regenerasi hutan untuk mengembalikan kesuburan tanahnya yang disebut sebagai masa bera kurang lebih sekitar 8 sampai 15 tahun $^{11}$, di Long Ampung sekitar 8 sampai 12 tahun dan di Long Segar sekitar 12 sampai 15 tahun.

Hasil penelitian Riswan dan Kartawinata (1985) dalam Soedjito dan Kartawinata (1987) mengemukakan bahwa hutan sekunder "jekkau" (hutan sekunder yang berumur sekitar 15 tahun) lebih tinggi kesuburannya dibandingkan dengan hutan $\mathbf{m b a}$ '(hutan rimba/primer), berdasarkan analisis kandungan nitrogen pada daundaun dari jenis tumbuhan yang berasal dari hutan sekunder lebih tinggi dibandingkan dengan yang berasal dari hutan rimba (penelitian dilakukan di Long Sungai Barang, Apo Kayan, Kalimantan Timur).

Orang Dayak memiliki pola tertentu dalam sistem pengelolaan tanah dan hutan yang membentuk siklus kurang lebih sama dengan masa bera. Proses pengembalian unsur hara ke dalam tanah secara alami bergantung dari tumbuh-tumbuhan hutan. Dengan 
demikian secara tidak langsung ada ketergantungan terhadap hutan bagi masyarakat Dayak untuk mengembalikan kesuburan tanah. Pola pengelolaan lahan dengan sistem gilir balik seperti ini memungkinkan untuk mengelola lahan tertentu saja dan membiarkan lahan lainnya tetap hutan rimba. Sebagai bukti terakhir sejak perpindahan kelompokkelompok suku yang menempati lokasi-lokasi sekarang menunjukkan masih adanya hutan rimba yang lebat dekat dengan kampung namun tidak digunakan untuk membuat ladang. Hutan rimba ini dipertahankan dan dikelola berdasarkan hukum adat secara lokal, yang disebut tana' ulen (lihat dibawah).

Ada beberapa alasan mengapa orang Dayak cenderung masih suka membuat ladang. Topografi yang bergunung-gunung dengan lereng yang agak curam sulit membuat sawah dan saluran irigasi. Kebanyakan mereka yang memiliki lokasi lahan di tempat datar sudah menggunakan lahannya untuk membuat sawah. Walaupun demikian karena sawah masih dipandang sempit mereka tetap membuat ladang untuk meningkatkan hasil padi selain yang dari sawah. Mereka mengatakan bahwa hasil dari sawah saja tidak cukup. Hasil padi ini biasa dijual untuk membeli berbagai kebutuhan pokok seperti: garam, gula, parang, sepatu belabak, dan lain-lain. Rata-rata ada $5 \mathrm{KK}$ sampai $14 \mathrm{KK}$ atau sekitar 15\% sampai 35\% keluarga per desa mendapatkan uang tunai dari menjual padi. Selain itu orang masih perlu membuat ladang untuk menanam sayur-sayuran seperti: timun, labu, jagung, kacang, ubi, pisang, pepaya, dan lain-lain. Sebagian orang suka membuat ladang karena rasa beras padi ladang jauh lebih enak dan harum dibanding dengan rasa beras padi dari sawah. Sebagian mengatakan karena pengaruh kebiasaan dan tradisi budaya yang sudah turun-temurun dari dulu, sehingga walaupun sudah memiliki sawah mereka tetap membuat ladang.

Mengapa orang Dayak masih suka membuat ladang dengan membuka hutan rimba, alasannya adalah untuk kepemilikan lahan. Menurut hukum adat, siapa yang membuka hutan rimba pertama kali maka merekalah yang berhak memiliki dan mengelola tanah tersebut. Sedangkan jika orang lain mau menggarapnya mereka boleh meminjam selama diberi ijin. Oleh sebab itu mereka membuka hutan rimba untuk mempersiapkan lahan untuk anak-anak mereka. Sebelum 
membuka hutan mereka harus mengadakan rapat dan minta ijin dari kepala desa atau kepala adat. Hal ini hanya kadang-kadang terjadi, biasanya mereka membuka hutan rimba hanya apabila sudah terbentuk rumah tangga baru dalam keluarga, kemudian mereka memisahkan diri dari keluarga orang tuanya dengan membuat rumah baru. Kebanyakan keluarga baru masih tinggal bersama orang tuanya untuk mengelola lahan bersama-sama. Tanda-tanda batas kepemilikan lahan antar penduduk di hutan adalah pohon-pohon, sungai kecil, batu atau tanda alam yang lain.

Beberapa masyarakat lainnya mengatakan bahwa ada kecenderungan masyarakat untuk membuat sawah, karena hasil sawah lebih baik dibandingkan dengan hasil ladang sedangkan hama padi di ladang lebih banyak daripada di sawah. Hal ini disebabkan oleh dekatnya ladang dengan hutan rimba. Hama padi terdiri dari berbagai jenis serangga, burung, dan mamalia kecil dan besar. Hama dari serangga antara lain: tekunyung (=wereng: Nilavarwata lugens), bekulun (=penggerek batang padi: Tryporiza incertulas ), ulet pute' (=larva: Tryporiza incertulas), ulet bileng (=larva: Heliothis armigera), pau (Locusta spp.), asu bulan (Famili: Gryllotalpidae). Hama dari jenis burung yang paling umum adalah: upit saleng (Lonchura fuscans), dan upit bala (Lonchura malacca). Hama dari jenis mamalia kecil adalah belabau uma' (Rattus rattus), dan belabau jami (Rattus tiomanicus). Hama yang merupakan mamalia besar adalah kuyat (Macaca fascicularis), ba'bui (Sus barbatus), dan payau (Cerrus unicolor).

\section{Ketergantungan Masyarakat Dayak terhadap Hutan Sebagai Perlindungan Sumber Air}

Masyarakat membutuhkan air bersih untuk minum, mandi, mencuci, dan sebagainya. Hutan berfungsi untuk mengatur sumber air yang sangat penting bagi masyarakat. Selain air bersih, masyarakat sangat tergantung pada air sungai untuk transportasi, tenaga listrik dan irigasi untuk sawah serta kolam. 


\section{a. Kebutuhan air bersih}

Di hulu Sungai Bahau di mana hutan masih bagus, air sungai tetap mengalir sepanjang tahun. Di musim kemarau juga masih terdapat hujan walaupun dengan intensitas yang lebih kecil. Airnya bersih bebas dari pencemaran. Masyarakat di sana pada umumnya terbiasa dengan keadaan yang alami dan lestari. Mereka khawatir dengan pencemaran lingkungan seperti yang sudah terjadi di daerah Malinau, khususnya di Long Loreh, pada Sungai Benuang ${ }^{12}$ yang dulu merupakan sumber konsumsi masyarakat. Masyarakat di Loreh banyak yang mengeluh tentang air minum, karena Sungai Benuang sekarang sudah tercemar oleh adanya perusahaan batu bara (lihat Foto 19). Pencemaran ini disebabkan oleh lumpur dari dalam tambang yang bercampur dengan air batu bara bekas tampungan hujan. Akibat kandungan lumpur yang pekat ini mengakibatkan air Sungai Benuang secara fisik tidak layak dikonsumsi. Pencemaran ini juga disebabkan oleh limbah oli, minyak solar, dan lain-lain karena ada kegiatan mekanik (bengkel) di sebelah industri pertambangan. Ada juga kekhawatiran masyarakat bahwa dalam kegiatan pertambangan terdapat bahan-bahan kimia yang mengandung racun.

Foto 19. Sungai Benuang yang tercemar oleh perusahaan batu bara (L. Loreh)

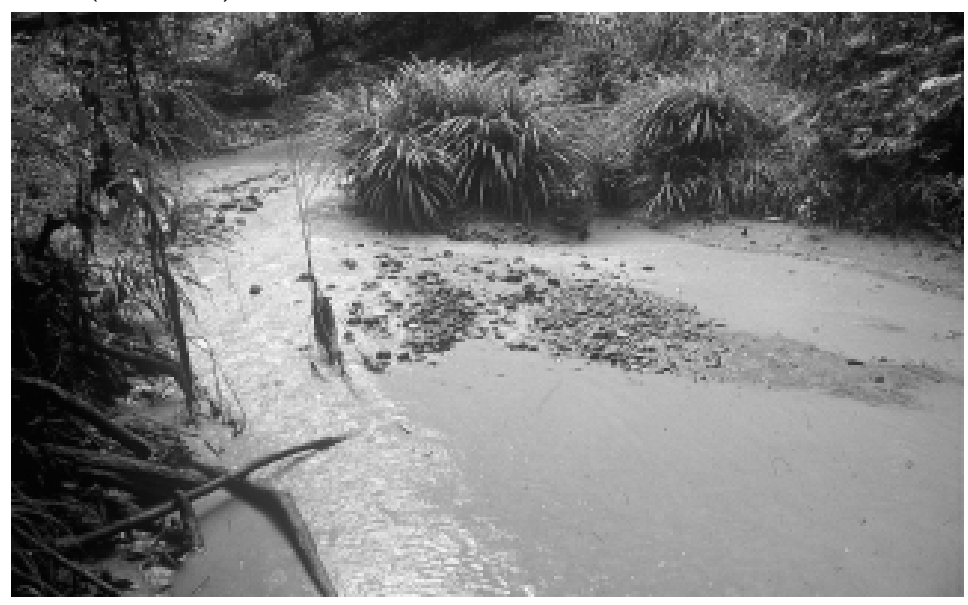


Masyarakat di hulu Sungai Bahau mempunyai hubungan keluarga dengan masyarakat di Long Loreh, maka informasi tentang keadaan air sungai di Long Loreh diketahui oleh masyarakat di Sungai Bahau. Hal ini menimbulkan kekhawatiran masyarakat tentang persediaan air bersih untuk kebutuhan sehari-hari di masa mendatang.

\section{b. Sawah}

Penggarapan sawah sangat tergantung pada persediaan air yang biasanya dialirkan dari anak sungai. Berbeda dengan pola perladangan yang telah dijelaskan di atas, membuat sawah merupakan pola perkembangan baru. Sejak Kepala Adat Besar Hulu Bahau "Apui Njau”" ${ }^{13}$, pada jaman Belanda pulang dari Jawa (konon beliau pernah belajar bersawah selama di penjara Belanda di Batavia) kira-kira tahun 1925-an beliau mengajarkan cara membuat sawah di wilayah Adat Hulu Sungai Bahau. Berkat peninggalan beliau itulah sehingga terdapat banyak sawah di wilayah Hulu Bahau sampai sekarang.

Perkembangan sawah sekarang nampaknya semakin banyak. Karena semakin banyak orang percaya bahwa hasil padi sawah lebih baik. Terutama jika terjadi musim kemarau, maka hasil padi sawah tetap baik, tetapi padi ladang sama sekali tidak baik. Sawah banyak terdapat di Long Tebulo, setiap keluarga yaitu $22 \mathrm{KK}$ atau $100 \%$ keluarga memiliki sawah dengan luas rata-rata 3 ha. Sedangkan di Long Alango luas sawah cenderung bertambah, saat ini ada $63 \%$ keluarga memiliki sawah, terhitung ada $47 \mathrm{KK}$ dari $75 \mathrm{KK}$ memiliki sawah dengan luas rata-rata sekitar 2 ha. Di Long Uli 76\% keluarga mempunyai sawah, dari $17 \mathrm{KK}$ ada $13 \mathrm{KK}$ yang membuat sawah. Di Apau Ping sebanyak 24\% keluarga mempunyai sawah, dari $51 \mathrm{KK}$ ada $12 \mathrm{KK}$ yang membuat sawah. Di Long Berini tidak ada sawah. Di Long Kemuat $100 \%$ keluarga mempunyai sawah. Di Long Peliran ada $5 \mathrm{KK}$ yang membuat sawah dari jumlah keluarga $12 \mathrm{KK}$. Sedangkan di Pujungan hanya sedikit petani yang mempunyai sawah, yaitu hanya $5 \mathrm{KK}$ dengan luas rata-rata 0,5 ha. Di Long Aran ada 4 KK dengan rata-rata 0,25 ha. 
Ada juga pendapat bahwa jika sawah dikerjakan terusmenerus, maka lama kelamaan tanahnya akan tidak subur lagi. Alasan ini juga yang menyebabkan mereka kembali ke ladang. Sebagian orang mengatakan, bahwa walaupun padi ladang itu subur, tetapi kalau tidak mendapat air akan tidak ada buahnya. Sebaliknya, walaupun padi sawah itu kurus tetapi tetap ada buahnya. Ada juga yang mengatakan bahwa kesuburan di sawah itu tetap saja. Sawah peninggalan Apui Njau dari tahun 1925 masih dikerjakan sampai sekarang kurang lebih sudah berusia 75 tahun, namun masih tetap subur. Di Long Tebulo orang sudah mengerjakan sawah selama lebih dari sepuluh tahun tetapi masih tetap subur. Namun pada umumnya beberapa orang yang punya sawah juga mengerjakan ladang. Selama dua tahun belakangan ini banyak keluhan dari masyarakat, karena panen padi di ladang gagal akibat musim kemarau panjang (lihat Foto 20). Banyak di antara mereka yang ingin mengerjakan sawah saja. ${ }^{14}$

Hasil padi sawah cenderung lebih stabil, sedangkan hasil padi ladang kadang banyak kadang sedikit sekali. Jika dibandingkan hasil rata-rata per ha antara padi ladang dan padi sawah, maka padi sawah lebih banyak hasilnya. Sebagai contoh, ladang seluas 4 ha membutuhkan

Foto 20. Dampak kemarau panjang pada hutan di L. Alango (Agustus 1990)

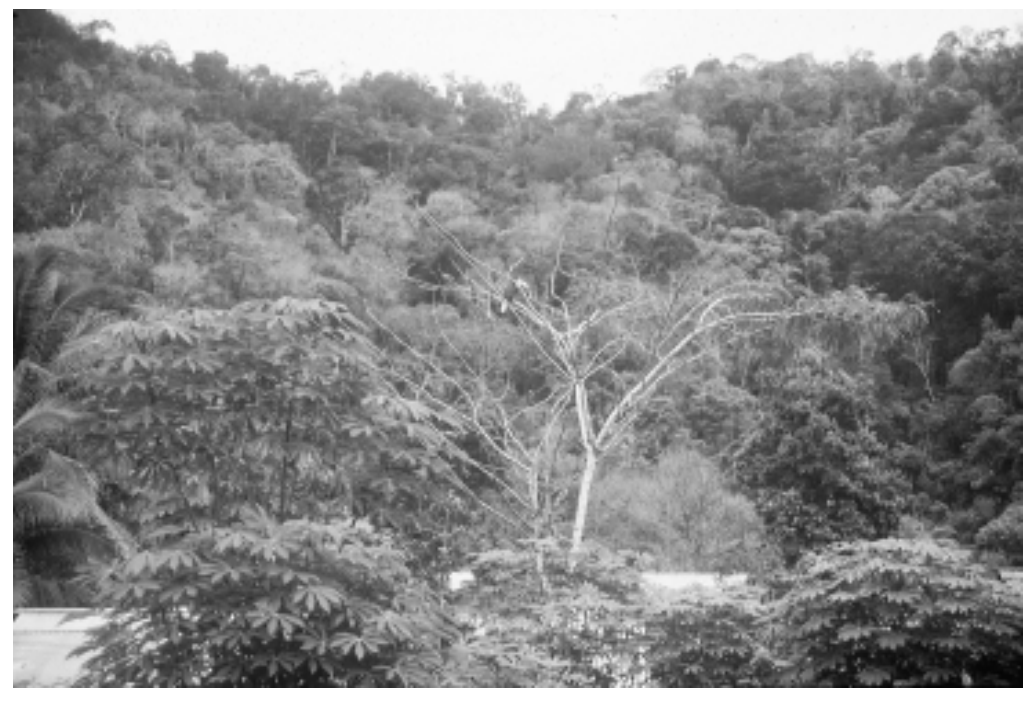


bibit rata-rata 6 kaleng (1,5 kaleng per ha). Hasil ladang semuanya kurang lebih 100 kaleng ( 25 kaleng per ha). Luas sawah 2 ha membutuhkan bibit rata-rata 1 kaleng (0,5 kaleng per ha). Hasil sawah semuanya 80 kaleng (40 kaleng per ha). Hasil padi sawah jauh berlipat ganda dibandingkan hasil padi ladang. Perbedaan curahan waktu dan tenaga kerja antara padi sawah dan padi ladang belum jelas di Hulu Bahau, tetapi menurut beberapa orang, padi sawah lebih ringan.

\section{c. Kolam ikan}

Pada perkembangan belakangan ini nampaknya banyak masyarakat yang mulai membuat kolam ikan yang disebut beng atuk (Leppo' Ké). Kebutuhan air untuk kolam dialirkan dari anak-anak sungai yang mata airnya berasal dari lereng-lereng gunung yang berhutan lebat. Banyak jenis ikan yang sudah dikembangbiakkan di kampungkampung di Hulu Sungai Bahau. Kolam dibuat pertama kali di Long Alango pada tahun 1957-58 oleh Apui Njau dengan membawa ikan mujair dari Tanjung Selor. Kemudian banyak orang yang memelihara ikan di Long Alango dengan membuat kolam di sebelah timur kampung, sampai sekitar tahun 1970-an. Setelah itu timbul anggapan dari masyarakat, bahwa dengan adanya kolam di sebelah timur kampung lama-kelamaan dapat mengakibatkan erosi dari rembesan air yang mengalir di bawah kampung ke arah barat menuju Sungai Bahau. Akibatnya bisa menghanyutkan kampung tersebut. Dengan adanya anggapan ini banyak orang berhenti membuat kolam.

Kemudian pada bulan Februari 1997 pertanyaan itu diajukan kepada staf World Wide Fund for Nature (WWF) Kayan Mentarang yang kebetulan melakukan pertemuan di Long Alango. Dialog dengan masyarakat waktu itu, staf WWF Kayan Mentarang menyatakan bahwa tidak apa-apa bila dibuat kolam di sebelah timur kampung. Penyebab erosi bukan kolam melainkan jika kayu-kayu di pinggir sungai di tebang, maka akar-akar yang mengikat tanah akan mati dan tanah akan mudah longsor. Setelah itu sekitar tahun 1998-99 banyak lagi orang membuat kolam sampai sekarang. Ada sekitar 40\% rumah tangga di Long Alango memiliki kolam khusus untuk ikan. Sedangkan 
beberapa keluarga lainnya memelihara ikan di sawah. Di Long Tebulo sekitar 50\% keluarga memiliki kolam ikan secara khusus dan ada juga yang memelihara ikan di sawah. Di Apau Ping hanya satu keluarga yang memiliki kolam ikan. Ikan yang paling banyak dipelihara di kolam, yaitu ikan mujair dan ikan mas yang didatangkan dari Tanjung Selor atau Tarakan. Bibitnya dapat dipesan dengan naik pesawat MAF. Ikan ini cepat berkembang biak dan cocok di air tenang. Selain bibit ikan yang didatangkan dari luar ada juga ikan yang ditangkap di Sungai Bahau dipelihara di kolam. Sampai saat ini banyak jenis ikan sungai yang sudah dipelihara termasuk yang hanyut melalui saluran air yang berasal dari bendungannya di hulu sungai.

Di depan telah disebutkan bahwa rata-rata ada sekitar 73\% sampai $100 \%$ ikan dipanen dari yang hidup secara liar. Berarti ada sekitar 0\% sampai 27\% dipanen dari hasil budidaya atau kolam. Adanya kolam dapat memenuhi konsumsi ikan sewaktu-waktu apabila diperlukan secara tiba-tiba, misalnya kedatangan tamu, ikan di kolam menjadi simpanan yang mudah diambil. Selain itu, memelihara ikan di kolam juga dapat mengurangi penangkapan ikan liar di sungai, sehingga kelestarian ikan di alam bisa dipertahankan. Di lain pihak, ada kemungkinan dampak ikan peliharaan yang didatangkan dari luar ini terhadap ekosistem liar apabila nanti ada yang terlepas ke sungai. Ikan mujair yang cepat berkembang biak dapat menjadi pesaing bagi jenis ikan yang hidup di habitat aslinya di sungai. Dampak ini belum jelas sekarang.

\section{d. Pembangkit listrik tenaga air}

Sejak tahun 1990an air sungai juga dibutuhkan sebagai pembangkit listrik tenaga air (PLTA). Dengan menggunakan PLTA masyarakat memperoleh listrik untuk penerangan, TV, radio, tape, untuk dinamo mesin penggilingan padi, mengetam kayu, dan lain-lain.

Ada enam desa yang sudah menggunakan PLTA di hulu Sungai Bahau. PLTA pertama kali dibuat di Long Alango pada tahun 1993, mula-mula secara swadaya lalu dibantu oleh Menteri Kehutanan Djamaludin Suryohadikusumo pada tahun 1996. Di lokasi Apau Ping 
dibuat PLTA pada tahun 1994 oleh orang Swis (anggota misi dari gereja) untuk keempat desa yaitu Desa Apau Ping, Long Pengayan, Long Tua, dan Long Lat. Di Long Tebulo dibuat PLTA pada tahun 1994 secara swadaya, dan masih rencana untuk membuat PLTA di Long Berini dan Long Kemuat. Penggunaan PLTA ini tidak menimbulkan pencemaran udara, dan menghemat pengeluaran uang karena mengurangi konsumsi bahan bakar minyak. Lestarinya hutan di hulu sungai dapat menyediakan air dalam jumlah yang konstan sehingga listrik tetap berjalan.

\section{Ketergantungan Masyarakat Dayak terhadap Hutan sebagai Sumber Genetik Bibit Tumbuhan atau Binatang}

Orang Dayak suka menanam bibit tumbuhan yang bermanfaat bagi mereka. Tumbuhan ini biasanya ditanam dekat rumah yang disebut pula (kebun). Apabila mereka pindah kampung maka bekas kampung dengan kebun buahnya ini di sebut lepu' un. Di hutan diambil bibit tumbuh-tumbuhan yang baik, dipilih berdasarkan pengalaman mereka untuk mendapatkan hasil yang lebih baik dan lebih banyak. Bibit tumbuhan yang diambil dari hutan masih sedikit jenisnya, sebagai contoh: dian da'un (Durio oxleyanus), dian kalang (Durio ribethinus), isau bala (Dimocarpus longan ssp1.), isau bileng (Dimocarpus longan ssp2.), bua' a'bung (Nephelium ramboutan-ake), bua'sanggit (Nephelium lappaceum), bua' unjing (Nephelium maingayi), berenyiu (Mangifera caesia), mangga (Mangifera indica), alim (Mangifera pajang), nakan (Artocarpus integer), kian (Artocarpus odoratissimus), basut (Artocarpus lanceifolius), bitung (Garinia mangostana), langset (Lancium domesticum), payang (Pangium edule), kayu me (Cinnamomum burmanni), uwai seka (Calamus caesius) (lihat Foto 21), daun dalui (Halopegia blumei), bekkai lan (Pycnarhena cauliflora), bekkai lanya (Coscinium miosepalum), belengla (Litsea cubeba), uba tepuh (Eugenia sp.) sejenis daun salam, ulem (Solanum torum), dan lain-lain. Jenis-jenis ini sudah ditanam di kebun-kebun dari dulu. Di masa mendatang mungkin lebih banyak lagi bibit tumbuhan yang dibutuhkan. 
Foto 21. Uwai seka (rotan) yang diambil dari hutan untuk ditanam di kebun (Apau Ping)

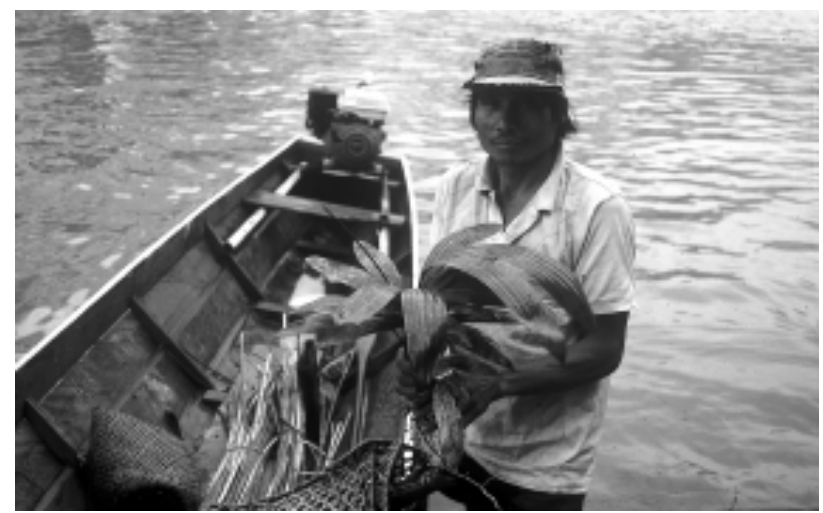

Hasil penelitian ini menunjukkan bahwa baru sedikit saja tumbuh-tumbuhan yang dibudidayakan untuk ditanam di kebun. Hasil dari hutan liar lebih besar dibandingkan dengan hasil pertanian. Telah disebutkan bahwa hasil pertanian berkisar antara 11\% sampai $25 \%$ saja. Berdasarkan hasil perhitungan data bahwa buah-buahan yang dipanen dari hasil budidaya pertanian atau penanaman di kebun berkisar antara 62\% sampai $83 \%$, selebihnya dipanen dari yang tumbuh liar di hutan. Sayur-sayuran yang dipanen dari hasil budidaya berkisar antara $15 \%$ sampai $28 \%$. Kayu yang dibudidayakan masih sangat sedikit, sekitar 5\% sampai $6 \%$ yang dipanen dari yang ditanam mungkin karena masih banyak tersedia di hutan liar, bambu dan rotan sekitar 1\% sampai $5 \%$ dihasilkan dari tumbuhan yang ditanam, obat dan bahan kesehatan kulit sekitar $57 \%$ sampai $64 \%$, bumbu $27 \%$ sampai 30\%, daun untuk bungkus, atap dan kerajinan tangan sekitar 33\% sampai 52\%, bahan upacara 36\% sampai 56\%.

Bibit tumbuhan yang berasal dari hutan liar ini memiliki genetik $^{15}$ yang beraneka ragam. Orang Dayak bisa memilih jenis-jenis tumbuhan untuk dijadikan bibit sesuai dengan sifat genetik yang dimilikinya, seperti rasa manis, buahnya banyak, buahnya yang besar, dan sebagainya. Keanekaragaman genetik ini akan dibutuhkan di masa mendatang untuk memenuhi berbagai kebutuhan hidup manusia 
seperti: bahan makanan, obat-obatan, perkakas dan sebagainya. Kebutuhan terhadap suatu genetik tertentu berubah sesuai dengan keadaan alam, selera masyarakat, dan konsumsi pasar. Tersedianya berbagai genetik tumbuhan dan makhluk hidup di hutan merupakan cadangan berbagai kebutuhan umat manusia di masa yang akan datang.

Selain bibit tumbuhan, bibit binatang sudah ada yang dimanfaatkan antara lain: ba'bui (babi hutan: Sus barbatus) dan payau (Cerrus unicolor). Sebagai contoh, babi hutan sering ditangkap pada saat berenang menyeberangi sungai. Anak babi hutan yang masih kecil ditangkap kemudian dipelihara di rumah. Pada waktu masih kecil anak babi hutan ini terus menerus diberi makanan sehingga menjadi jinak. Hal ini sering dilakukan di Long Alango. Ada sekitar 10\% sampai 15\% rumah tangga di hulu Sungai Bahau memelihara babi hutan. Babi hutan sangat mudah menyesuaikan diri dengan makanannya. Babi dapat makan singkong, talas, dan sisa-sisa nasi yang tidak dimakan lagi. Pemeliharaan babi hutan ini dapat memberi kesempatan untuk melakukan kawin silang dengan buin (babi peliharaan: Sus domesticus), untuk mendapatkan bibit unggul yang tahan terhadap penyakit, mudah mengurus makanannya, cepat besar dan gemuk. Pemeliharaan babi dapat menggantikan daging binatang buruan, sehingga konsumsi binatang dari alam bisa dikurangi untuk dilestarikan.

Sedangkan bibit ikan yang berasal dari sungai yang sudah dibudidayakan ada beberapa jenis. Pak Jan Lawai di Long Alango mengatakan bahwa ia lebih banyak memelihara jenis ikan yang bibitnya diambil dari Sungai Bahau. Contohnya ikan selareng (=patin: Pangasius sp.), salap (Barbodes balleroides), padek (Tor if. tambra), kati (=lele: Chana sp.), betelo (Rasbora sp.), dan lain-lain. Selain bibit ikan yang diambil secara sengaja di sungai, juga ada bibit ikan yang kebetulan masuk ke kolam ikut aliran air dari hulu sungai yang jenisnya bermacam-macam. 


\section{Ketergantungan Masyarakat Dayak terhadap Ekosistem Hutan sebagai Hubungan yang Saling Terkait}

Secara langsung ataupun tidak langsung orang Dayak sangat tergantung pada ekosistem hutan. Hutan merupakan sumber makanan dan perlindungan berbagai jenis satwa yang membentuk interaksi yang saling terkait. Jika salah satu jenis satwa terganggu maka satwa yang lain juga dapat terganggu. Begitu pula jika hutan terganggu maka tempat mencari makan orang Dayak akan terganggu yang akibatnya hasil buruan mereka juga berkurang. Akibat selanjutnya, jika tidak ada pilihan lain maka makanan orang Dayak juga berkurang. Oleh sebab itu orang Dayak melindungi hutan tertentu agar selalu mendapatkan binatang buruan. ${ }^{16}$

Dalam kaitannya dengan ketergantungan orang Dayak terhadap ekosistem hutan ini dapat dijelaskan dari kehidupan mereka tentang cara mencari nafkah. Orang Dayak mengamati beberapa indikasi sebagai ciri di mana dan kapan ada binatang. Berdasarkan indikasi ini maka orang Dayak mudah mendapatkan binatang buruan. Ada suatu tempat yang disukai oleh binatang untuk minum ataupun mencari makanan. Juga ada cerita orang Dayak tentang hubungan babi dengan lebah, babi dengan $\boldsymbol{d u k}$, dan babi dengan kupu-kupu dalam kaitannya binatang ini mencari makan di dalam hutan. Di sungai juga orang Dayak mengamati perilaku ikan dan di mana ikan biasa terdapat dalam jumlah banyak.

\section{a. Sungan dan ketina' ba'bui tempat berburu}

Di dalam hutan terdapat tempat binatang biasa minum yaitu di sumber air asin yang disebut sungan. Orang Dayak sudah tahu di mana tempat-tempat sungan tersebut. Binatang yang biasa minum air sungan adalah bangat (Presbytis hoser) dan uca' ano (Muntiacus muntjac) biasanya waktu pagi sekitar jam 9 sampai jam 10 dan sore sekitar jam 3 sampai jam 4. Sedangkan yang biasa minum waktu malam hari adalah payau (Cerrus unicolor). Sungan ini biasanya terdapat di pinggir 
anak-anak sungai yang kecil. Sungan ini dilindungi oleh orang Dayak. Siapapun yang datang berburu di sungan ini tidak boleh menebang kayu atau memotong pohon-pohon kecil di sekitarnya. Mereka khawatir kalau sungan ini rusak maka binatang tidak mau lagi minum di sana.

Selain sungan ada juga tempat babi berkubang yang disebut ketina' ba'bui. Ketina' ini biasa terdapat di pematang gunung, di lereng, dan di tempat-tempat biasa air tergenang. Ketina' ada yang berbentuk kubangan biasa seperti kolam dan ada juga yang berbentuk lubang seperti goa. Di ketina' ini biasanya babi tidur.

Orang Dayak berburu dengan mengintip binatang buruan di sungan atau di ketina' dengan menggunakan bujak atau sumpit. Selanjutnya dijelaskan pada bagian lain dalam tulisan ini.

\section{b. Hubungan babi dan duk dimanfaatkan untuk berburu}

Ada suatu cerita tentang pola babi dan $\boldsymbol{d} \boldsymbol{u k}$ dalam mencari makanan. Menurut orang Dayak di mana ada musim buah yang banyak, ke situ babi hutan berpindah mencari makanan. Babi yang berpindah ini mengikuti jenis monyet yang disebut duk (Macaca nemestrina). Babi dan duk membentuk hubungan yang saling menguntungkan (simbiosis mutualisme). Duk makan buah di atas pohon sambil menjatuhkan kulit dan bijinya. Sedangkan babi di bawah pohon memakan jatuhan sisa-sisa duk tersebut dari atas. Kadang-kadang babi juga dapat buah yang baik. Kalau babi sudah kenyang makan, maka babi tidur di tanah. Kemudian $\boldsymbol{d u k}$ turun untuk mencari kutu babi untuk dimakan. Biasanya babi banyak sekali kutunya. Babi senang dicari kutunya karena mengurangi rasa gatal maupun sakit di badannya. Duk senang karena mendapat makanan enak. Inilah sebabnya babi suka mengikuti duk. Jika ada suara duk maka babi akan datang ke sana. Dengan pengetahuan ini, maka orang Dayak sering menirukan suara dukuntuk menipu babi agar datang mendekat. Jika sudah dekat langsung dibujak (ditombak). Cara berburu seperti ini disebut ngeduk. Selanjutnya akan dijelaskan pada bagian kebudayaan. 
Hampir semua jenis buah-buahan di hutan disukai oleh $\boldsymbol{d u k}$ dan babi. Di mana buah-buahan ini terdapat dijadikan indikasi bahwa di situ biasa ada babi dan duk. Sebagai contoh buah-buahan yang paling disukai yaitu: settai (Baccaurea macrocarpa), lepesso (Baccaurea lanceolata), konye (Baccaurea parriflora), keramo' (Dacryodes rostrata), mejalin (Xanthophyllum scortechinii), mejalin batu (Xanthophyllum excelsa), isau bala (Dimocarpus longan ssp1.), isau bileng (Dimocarpus longan ssp2.), bua' a'bung (Nephelium ramboutan-ake), bua' sanggit (Nephelium lappaceum), bua' unjing (Nephelium maingayi), berenyiu (Mangifera caesia), mangga (Mangifera indica), alim (Mangifera pajang), adiu (Garcinia forbesii), bitung (Garcinia mangostana), langset (Lancium domesticum), penjae (Hopea mengerawan, =laran ba'bui artinya buah laran yang suka dimakan babi), bua' palan (Lithocarpus nieuwenhuisii), bua' palan timai (Lithocarpus conocarpus), bua' bangan (Castanopsis argentea), bangan su'et (Lithocarpus coopertus), nyeliway (Quercus argentata), bua' beta (Parkia speciosa), dan masih banyak buah yang lain.

\section{c. Hubungan babi dan lebah dalam perpindahan dimanfaatkan untuk berburu ba'bui satung}

Menurut pengalaman orang Dayak ada hubungan antara babi dan lebah waktu perpindahan ke lokasi lain. Konon babi berpindah mengikuti lebah, di mana lebah ini mencium bau bunga yang banyak maka mereka pindah melawan arus angin mencari sumber bau bunga tersebut. Umumnya kalau lebah pindah dalam koloni besar suaranya nyaring dan babi mendengar mereka ke mana arahnya. Babi mengikuti arah yang diisyaratkan oleh lebah tersebut. Dalam perjalanannya mereka bertemu dengan pasangannya lalu kawin. Babi hamil sampai di tempat tujuan menunggu musim buah jatuh siap melahirkan anaknya. Anak babi yang baru lahir mendapatkan makanan berlimpah di musim buah.

Perpindahan babi ini sering melewati sungai-sungai besar dekat dengan perkampungan. Apabila musim babi pindah (migrasi) masyarakat suka menghadang di pinggir sungai, karena babi yang 
berpindah biasanya dalam rombongan yang besar sekitar 10 sampai 30 ekor babi dewasa dan bahkan bisa mencapai ratusan jika anak mereka banyak. Saat babi menyeberangi sungai, babi-babi tersebut berenang secara serentak. Musim babi berenang disebut ba'bui satung, ketika babi sedang berenang disebut ba'bui nyatung ${ }^{17}$. Babi yang sedang berenang ini sangat mudah ditangkap, baik dengan bujak (tombak) atau parang (pisau), kadang-kadang ditangkap hidup-hidup jika babi tersebut masih kecil. Babi yang masih kecil ini dipelihara di rumah. Jika sudah besar baru dipotong. (Lihat bab hutan sebagai sumber bibit binatang peliharaan).

\section{d. Kupu-kupu digunakan sebagai tanda musim berburu ba'bui satung}

Kupu-kupu kuning dan hijau di pinggir sungai yang berkelompok dalam jumlah besar digunakan sebagai tanda adanya musim ba'bui satung. Kalau ditanyakan kepada orang Dayak, mengapa kupu-kupu dijadikan ciri untuk musim babi berenang, biasanya mereka mengatakan itu adalah pengalaman dari dulu, katanya.

Cerita ini nampaknya terkait juga dengan perpindahan babi yang mengikuti lebah berpindah pada saat musim bunga. Kemungkinan kupu-kupu ini menetas dari kepompongnya tepat pada saat musim bunga mulai. Pada saat perpindahan babi ini, kupu-kupu suka mengisap garam yang berasal dari kencing dan kotoran binatang. Biasanya babi dalam rombongan yang banyak suka mencari cacing di tempat-tempat becek di pinggir sungai sambil meninggalkan kencing dan kotorannya. Hubungan ekologi antara kupu-kupu dan babi inilah yang digunakan oleh orang Dayak untuk mengetahui kapan ada babi dalam jumlah banyak, terutama untuk berjaga-jaga kemungkinan ba'bui satung.

Jadi hubungan antara musim bunga, perpindahan lebah, kupukupu menetas dari kepompong, musim buah, dan perpindahan babi memiliki siklus secara periodik yang tentunya dipengaruhi oleh iklim dan musim. Saling keterkaitan antara faktor-faktor yang menentukan siklus ini di alam, berperan bagi orang Dayak secara tidak langsung. 


\section{e. Hubungan antara ikan dengan pohon dimanfaatkan saat menjala}

Selain yang telah disebutkan di atas, hutan juga mempengaruhi ikanikan di sungai. Secara tidak langsung tumbuh-tumbuhan di dalam hutan menghasilkan buah-buahan yang merupakan makanan bagi ikan. Hampir semua jenis buah-buahan yang jatuh di sungai dimakan oleh ikan. Jenis buah yang paling disukai oleh paling banyak jenis ikan adalah buah dari berbagai jenis Ficus seperti: bua' lunuk (Ficus stupenda), bua'lunuk nyambung (Ficus xylophylla), bua'lunuk timai (Ficus benjamine), abung aa' (Ficus glomerata), a’bung bileng (Ficus hemsleyana), abung selareng ${ }^{27}$ (Ficus uncinata), dan hampir semua jenis ficus yang lain. Buah pohon yang lain yang juga disukai adalah $\boldsymbol{b u a}^{\prime}$ laran (Dipterocarpus oblongifolius) dan hampir semua buah dari famili Dipterocarpaceae yang lainnya. Buah-buahan seperti isau (Dimocarpus spp.), a'bung (Nephelium spp.), juga banyak dimakan oleh ikan.

Menurut orang Dayak, ikan di hulu sungai lebih enak dibandingkan ikan di hilir (dekat laut). Di wilayah hulu sungai hutan masih bagus, banyak terdapat buah-buahan sebagai makanan ikan dibandingkan dengan sungai di bagian hilir yang tidak ada hutannya. Di musim buah-buahan ikan biasanya gemuk-gemuk. Dari hutan juga banyak terdapat serangga yang jatuh ke dalam sungai. Mungkin karena makanan ikan di dalam hutan lebih bervariasi maka rasa dagingnya lebih enak. Oleh sebab itu keutuhan hutan sangat penting terhadap ekosistem perairan sungai dan secara tidak langsung mempengaruhi daya dukung sumberdaya ikan terhadap kebutuhan masyarakat Dayak.

Di pinggir-pinggir sungai yang ada pohon ficus atau pohon lainnya yang sedang berbuah maka di dalam sungai di bawah pohon tersebut biasanya banyak terdapat ikan. Jika ada buah yang jatuh ke dalam sungai maka ikan-ikan yang sembunyi di bawah batu akan keluar mengejar buah tersebut. Kebiasaan ikan seperti ini sudah diketahui oleh orang Dayak, sehingga jika mereka menjala ikan maka dicari lokasi yang ada pohon di atas sungai. Di bawah pohon ini dilemparkan batu kecil, untuk menipu ikan agar keluar dari persembunyiannya. Ikan akan datang ke tempat batu itu dilemparkan dikira ada buah yang jatuh. Kemudian orang menebarkan jala di tempat tersebut. 


\section{e. Musim dingin digunakan sebagai tanda untuk menangkap atuk pale'.}

Pada bulan-bulan tertentu kondisi udara relatif dingin, air sungai kecil dan jernih karena kemarau. Pada saat itu ada suatu pola di mana ikan-ikan selalu bertelur. Ikan-ikan yang berasal dari sungai besar masuk ke sungai kecil untuk melepaskan telurnya. Biasanya jumlah ikan yang bertelur ini sangat banyak bisa sampai ratusan bahkan lebih. Musim ikan bertelur ini disebut atuk pale' (atuk=ikan, pale'=bertelur dan berkumpul). Sungai-sungai yang biasa dimasuki oleh ikan untuk bertelur hanya anak sungai tertentu saja, dan jenis ikan yang bertelur hanya jenis ikan tertentu untuk satu anak sungai. Ikan lainnya bertelur di anak sungai yang lain. Tetapi bisa juga ikan yang jenisnya berbeda bertelur di sungai yang sama pada musim yang lain. Setelah melepaskan telurnya ikan-ikan tersebut kembali ke sungai besar. Telur ikan tersebut nantinya akan menetas di sungai kecil dan baru masuk ke sungai besar setelah dewasa.

Orang Dayak hafal dengan perubahan iklim ini, ketika udara terasa dingin hal itu menandakan musim atuk pale'. Umumnya orang Dayak sudah siap menjaga di muara sungai untuk memasang pukat. Ikan yang di angkap hanya ikan yang besar-besar saja, sedangkan ikan kecil-kecil akan lolos lewat pukat tersebut. 


\section{Bab 3 \\ Keterkaitan Budaya Masyarakat Dayak terhadap Hutan}

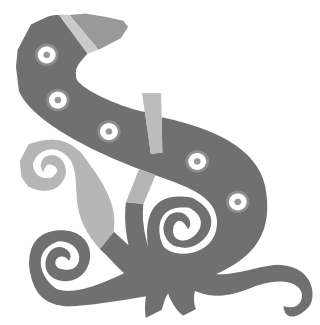

\section{A. PENGETAHUAN DAN KETERAMPILAN UNTUK MEMANFAATKAN HUTAN DAN MENGELOLA HUTAN}

Orang Dayak mewariskan ilmu pengetahuan tradisional untuk memanfaatkan dan mengelola hutan, sehingga orang Dayak terampil hidup di dalam hutan tanpa tersesat, dapat menyelamatkan diri dari binatang buas dan memperoleh makanan di hutan. Dalam mengelola hutan, orang Dayak sangat terampil sehingga tidak menimbulkan kerusakan hutan yang luas. Orang Dayak juga terampil mencari makanan dengan berbagai cara berburu, berbagai cara menangkap ikan, dan mencari sayur dari berbagai jenis tumbuhan.

\section{Di Hutan Tempat Mewariskan Ilmu Pengetahuan Tradisional}

Hutan berfungsi sebagai objek dan tempat belajar untuk mewariskan ilmu-ilmu tradisional dari orang tua kepada anaknya. Di hutan orang tua mengajar anak-anaknya tentang tumbuh-tumbuhan yang bisa dimakan, obat-obatan, tumbuhan beracun, bagaimana mengenal ciri- 
cirinya, apa namanya, dan bagaimana memanfaatkannya. Di hutan orang tua Dayak juga mengajar anak-anaknya berburu, ngasu (berburu dengan anjing), ngeduk (berburu meniru gaya monyet), meleput atau nyumpit (yaitu menembak dengan menggunakan hembusan angin dari mulut melalui pipa pembuluh), menjala, pasang pukat, dan lain-lain untuk mendapatkan nafkah sehari-hari.

Belajar di dalam hutan melalui kebiasaan yang semula ikutikutan masuk ke hutan dari sejak kecil, mereka secara tidak sengaja mendapatkan pengalaman dan pelajaran dari orang tuanya untuk mengenal hutan, cara menyelamatkan diri, dan berbagai cara hidup di dalam hutan. Pengetahuan yang diwariskan secara turun-temurun itu merupakan pendidikan informal yang sangat berharga bagi orang Dayak maupun masyarakat luas apabila dikaji dan dikembangkan lebih lanjut. Sebagai contoh dalam mengenal tanaman obat dan racun, manfaatnya untuk jenis penyakit apa, bagaimana cara pengolahannya, dan sebagainya. Pengetahuan ini juga penting bagi masyarakat luas.

\section{Keterampilan Orang Dayak Dalam Berbagai Cara Berburu dan Menangkap Ikan}

\section{a. Minjung}

Berbagai cara dilakukan oleh orang Dayak untuk memenuhi kebutuhan bahan makanan (lihat juga Puri 1997). Antara lain adalah minjung yaitu berburu dengan cara meleput atau nyumpit. Anak sumpit yang sangat ringan terdorong oleh angin di dalam pipa pembuluh dapat melesat sejauh $100 \mathrm{~m}$. Buruan yang berjarak sekitar 10 sampai $15 \mathrm{~m}$ akan terluka apabila kena oleh anak sumpit tersebut. Biasanya anak panah ini tertancap di tubuh binatang buruan. Anak sumpit yang mengandung racun dapat membunuh binatang sejenis kuyat, kijang, pelanuk, beruang, dan sebagainya dalam tempo satu jam. Pada umumnya binatang yang sudah kena racun pasti mati tidak bisa bertahan hidup. Jenis-jenis burung besar seperti temengang (Buceros rhinoceros) dan teba'un (Rhinoplax irgil) juga bisa mati. Untuk meniup sumpit dengan menghembuskan angin yang kuat dari dalam 
mulut ada cara tertentu dan teknik yang baik yang sudah dikuasai oleh orang Dayak. Perburuan ini diatur dengan beberapa peraturan, terutama untuk babi (lihat bagian hukum adat di bawa).

Sebelum mereka pergi berburu ke dalam hutan mereka harus melihat arah angin. Mereka tidak mau mengikuti arah angin, sebab binatang mencium bau mereka yang dibawa oleh angin. Sebaliknya mereka pergi berburu dengan melawan arah angin. Dengan melawan arah angin ini, binatang buruan dapat ditelusuri di dalam hutan.

\section{b. Mabang sungan}

Selain itu pemburu juga dapat menunggu binatang yang datang minum air asin. Dalam bahasa Dayak Kenyah disebut mabang sungan (mabang $=$ menunggu, mengintai, menghadang; sungan $=$ mata air asin). Biasanya jenis-jenis binatang seperti bangat (Presbytis hoser), uca' ano (Muntiacus muntjac), dan jenis burung punai mba' (Treron curvirostra) suka minum air asin untuk mendapatkan mineral. Jika musim kemarau biasanya di pagi hari sekitar jam 9 sampai jam 10 dan sore hari sekitar jam 15 sampai jam 16, binatang tersebut datang ke sungan. Umumnya mereka berombongan.

Kalau angin baik biasanya binatang tersebut tidak mencium bau manusia, sehingga pemburu dapat berjaga-jaga dekat dengan sungan sekitar 10 sampai $15 \mathrm{~m}$. Pemburu tahu persis di mana mengambil posisi untuk menjaga dan dari mana arah binatang yang akan datang, supaya binatang tidak melihat mereka. Untuk mabang sungan ini mereka membuat tempat persembunyian dari daun-daun kayu yang diatur sedemikian rupa agar mereka terlindung.

Jika binatang sudah datang ke sungan kemudian minum, binatang yang datang pertama tidak disumpit. Binatang itu dibiarkan minum sampai puas, kemudian setelah rombongan berikutnya datang, biasanya lebih banyak, maka boleh disumpit. Jika binatang yang datang pertama disumpit maka rombongan berikutnya tidak mau datang. Jika kelompok bangat ada 11 ekor maka dapat disumpit 8 sampai 10 ekor. Di daerah hulu Sungai Bahau banyak terdapat sungan. Sehingga orang Dayak banyak punya pilihan untuk mengintai sungan yang mana disesuaikan dengan arah angin. 


\section{c. Mabang burung teba'un dan temengang}

Selain mabang sungan orang Dayak juga sering mabang burung teba'un dan temengang di pohon buah lunuk (Ficus xylophylla) atau lunuk timai (Ficus benjamine) yang biasa didatangi oleh burung itu. Sekelompok burung teba'un atau temengang yang datang dapat disumpit sampai semuanya jatuh. Tetapi kejadian ini jarang terjadi. Biasanya hanya dalam lima sampai sepuluh tahun sekali. Sebab bila sudah pernah menangkap burung ini, bulu burungnya bisa tahan sampai sepuluh tahun. Sedangkan menangkap burung ini untuk diambil dagingnya jarang terjadi.

\section{d. Mabang satung}

Di depan telah dijelaskan tentang orang yang mabang satung (menunggu babi berenang pada musim perpindahan babi). Di pinggir sungai pada waktu musim babi berenang banyak sekali orang menunggu dengan membawa senjata berupa bujak, parang, dan ketinting. Jika babi yang datang sudah mulai menyeberang ditunggu sampai dekat ke seberang di tempat orang menunggu. Ada aturan adat tidak boleh menembak babi yang sedang berenang, sebab dikhawatirkan mengenai orang yang ikut mengejar babi tersebut. Senjata yang dipakai hanya bujak dan parang. Selain itu, tidak boleh orang menunggu babi atau pergi berburu ke tempat darimana asal babi tersebut menyeberang.

\section{e. Menjerat binatang dengan peru, labak, dan siang}

Selain cara yang telah disebutkan di atas orang Dayak juga menangkap binatang dengan menggunakan jerat. Ada dua jenis jerat yang umum dipakai yaitu jerat kaki yang disebut peru atau biru dan jerat leher yang disebut labak. Tali jerat ini dibuat dari tali kecil yang kuat dan halus. Jerat dipasang di tempat binatang biasa lewat. Ada jenis binatang tertentu yang memiliki jalan yang sering dilewati sehingga bekasnya 
nampak seperti alur. Di bekas-bekas jalan inilah biasa dipasang jerat. Bisa juga dibuat rintangan-rintangan di dalam hutan kemudian dibuat celah yang disebut awang (tempat jalan binatang) sehingga binatang tergiring ke celah ini. Di celah inilah dipasang jerat. Binatang yang biasa kena jerat jenis peru adalah uca' ano (Muntiacus muntjac), pelanuk (Tragulus javanicus), bekulu (Felis bengalensis), kule upa'(Vivera tangalunga), dan bilut (Echinosorex gymnurus). Sedangkan binatang yang biasa kena jerat untuk jenis labak adalah settung (Thecurus crassispinis), settung umung (Hystrix brachyura), dan bekia (Trichys fasciculata). Kadang ada juga yang memasang benda tajam dari bambu di celah ini yang disebut siang. Binatang yang biasa kena siang adalah payau (Cerrus unicolor), ba'bui (Sus barbatus), dan hampir semua binatang lainnya yang masuk ke situ.

\section{f. Ngeduk}

Cara yang paling unik untuk berburu adalah ngeduk. Di atas telah dijelaskan bahwa ada ketergantungan antara duk (Macaca nemestrina) dengan babi hutan (= $\boldsymbol{b a}^{\prime} \boldsymbol{b u i}$ : Sus barbatus) yang membentuk hubungan timbal balik yang saling menguntungkan. Hubungan baik kedua jenis binatang ini dimanfaatkan oleh orang Dayak untuk berburu. Mereka biasa berburu dengan cara ngeduk yaitu menirukan suara duk. Satu orang dapat berbunyi menirukan suara anak $\boldsymbol{d u k}$ dan induknya secara bergantian sehingga kedengaran seperti ada banyak duk di sekitar sana. Orang yang ngeduk tidak berpakaian yang berwarna mencolok. Mereka hanya menggunakan daun-daun untuk melindungi tubuh dan menyembunyikan badannya. Mereka memanjat pohon sambil menggoyang-goyangkan dahan kayu agar buah jatuh. Jika arah angin baik, maka babi akan datang kemudian menggulingkan badannya di atas tanah. Orang Dayak kemudian mendekati babi tersebut lalu mengelus-elus punggung babi itu sampai tertidur. Jika babi sudah tidur baru dibujaknya. Jika terjadi hal yang tidak menguntungkan sebelum babi dibujak, misalnya arah angin tiba-tiba berubah ke arah babi maka babi itu seketika lari menjauh karena takut kepada manusia. Cara ngeduk dikuasai oleh orang tua yang kebanyakan dilakukan oleh orang Punan dan beberapa subsuku di hulu Sungai Bahau. 


\section{g. Memanggil kijang}

Ada lagi cara yang lain untuk berburu yaitu khusus untuk mencari kijang. Cara ini adalah dengan memanggil kijang tersebut. Untuk menirukan suara kijang digunakan daun kayu ditiup di mulut sehingga menimbulkan suara seperti anak kijang. Induk kijang akan datang mendekat mengira ada anaknya yang memanggil. Si pemburu bersembunyi di balik pohon atau banir sambil mengintip kijang yang datang. Jika kijang yang diincar sudah dekat baru dibujaknya.

\section{h. Menangkap ikan dengan sikep, pancing, jala, dan pukat}

Untuk menangkap ikan biasa digunakan tangguk (sikep, pancing, jala, dan pukat). Sikep adalah alat berupa jaring yang bertangkai dibuat dari tali te' bala. Sikep biasa digunakan pada waktu air banjir dan keruh (lihat Foto 22). Waktu air besar, ikan suka di pinggir-pinggir sungai karena jika di tengah mereka hanyut oleh derasnya air. Karena air keruh ikan tidak bisa melihat orang. Dengan demikian sangat mudah ditangkap dengan sikep. Ada juga orang yang menggunakan pancing dengan tali khusus yang disebut tasi (tase'). Sedangkan jala digunakan bisa pada waktu air keruh maupun waktu air jernih. Tetapi lebih bagus menjala saat air keruh. Pukat biasa dipasang melintang di tengah sungai untuk menangkap ikan yang lewat. Ikan tertangkap karena siripnya menyangkut di pukat. Biasa juga orang memasang pukat di muara sungai kecil sebelum banjir. Apabila banjir datang maka ikan-ikan akan lari berlindung di sungai kecil karena takut hanyut terbawa arus yang deras. Saat itulah ikan tersebut kena pukat.

\section{i. Menangkap ikan dengan bubu dan bading}

Bubu dan bading adalah alat untuk menangkap ikan di sungai berupa perangkap yang dibuat dari bambu dianyam sedemikian rupa bentuknya bulat seperti botol dengan ukuran besar, kurang lebih panjangnya $1 \mathrm{~m}$ (lihat Foto 23). Bedanya adalah, $\boldsymbol{b u} \boldsymbol{b u}$ dipasang di pinggir sungai yang tenang (limbu= belilek), lobangnya menghadap 
Foto 22. Belanyat beta (kanan) dan sikep (kiri)

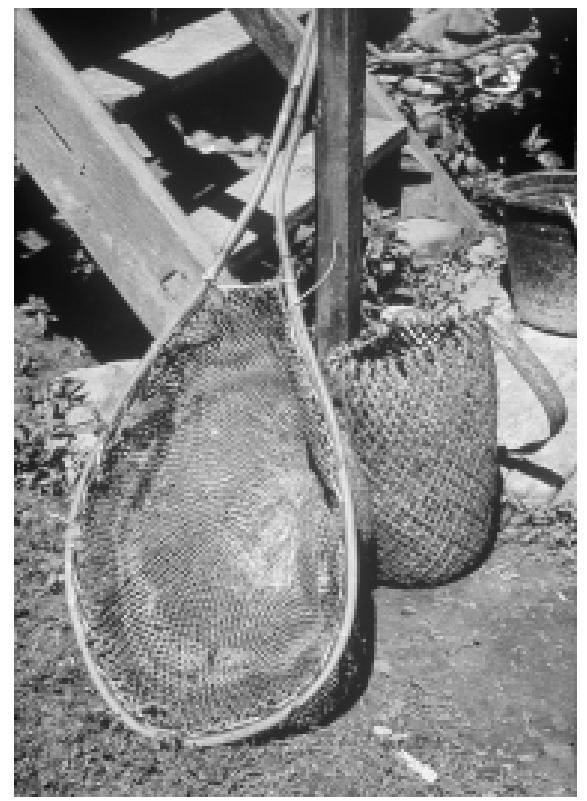

ke hilir. Di dalam $\boldsymbol{b u b u}$ dipasang umpan berupa makanan yang disukai oleh ikan. Ikan berenang ke hulu mencium bau umpan yang hanyut, akhirnya masuk perangkap. Sedangkan bading dipasang di tengah sungai yang deras, lebih di sukai di air terjun. Lobangnya menghadap ke hulu ke arah atas. Ikan-ikan yang hanyut dari hulu semuanya terperangkap di dalam bading. Bading tidak menggunakan umpan.

\section{j. Nyelapang atuk}

Pada waktu musim kemarau apabila air sudah jernih ikan-ikan akan terlihat di dalam sungai. Orang Dayak biasa menyelam untuk menangkap ikan dengan membawa selapang atuk yaitu semacam panah yang anak panahnya diikat dengan tali. Saat menyelam apabila menemukan ikan yang cukup besar, maka dipanah dengan selapang atuk ini. Anak panah ini tertancap di tubuh ikan, kemudian tali 
Foto 23. Bading

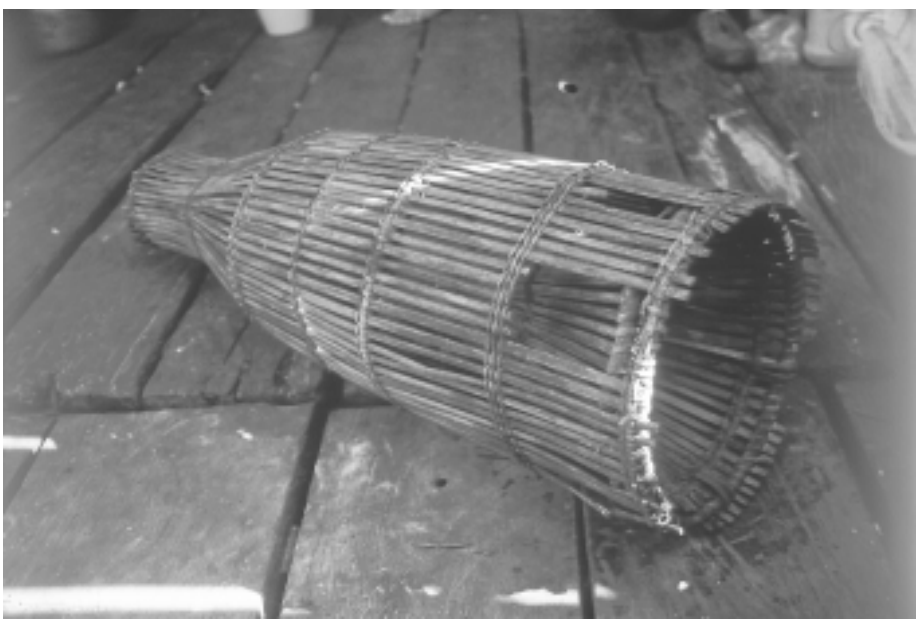

pengikat anak panah ini ditarik. Di ujung anak panah ada kait seperti pancing sehingga ikan tidak bisa lepas. Cara ini sering dilakukan oleh orang laki-laki remaja sampai orang dewasa.

\section{Keterampilan Orang Dayak Dalam Mengelola Hutan}

Orang Dayak melindungi sebagian besar hutannya untuk tempat berburu dan mencari hasil hutan lainnya, tidak semua hutan ditebang untuk dibuat ladang. Hutan yang dilindungi ini disebut dengan tana' ulen. Pengelolaan tana' ulen diatur dengan hukum adat. Tana' ulen selanjutnya dijelaskan pada bagian lain dalam tulisan ini.

Selain adanya tana' ulen yang dilindungi, pemanfaatan hutan lainnya juga diatur dengan ketentuan adat. Misalnya ada aturan bahwa tidak boleh menebang pohon atau semak dekat dengan sungan agar binatang tidak terganggu atau takut. Jika ada orang berburu ingin mengambil daun untuk persembunyian harus dibawa dari jauh.

Jika membuka hutan rimba untuk membuat ladang juga tidak boleh sembarangan, masyarakat harus bermusyawarah dulu baru boleh mulai menggarap. Sedangkan untuk mengelola padang alang- 
alang orang Dayak juga punya cara tertentu. Umumnya orang Kenyah yang tinggal di Apau Ping dan orang Punan yang tinggal di Sungai Lurah, mereka membakar padang alang-alang secara rutin. Padang alang-alang yang habis dibakar umumnya akan tumbuh tunas baru yang sangat digemari oleh kijang, payau, banteng, dan binatang pemakan rumput lainnya. Menurut mereka jika alang-alang tidak dibakar maka akan tumbuh semak-semak, lalu alang-alangnya hilang sehingga binatang yang suka makan rumput akan menjauh. Sebaliknya jika alang-alang rutin dibakar maka selalu ada rumput muda yang menyebabkan binatang buruan mendekat.

Sampai saat ini terdapat padang alang-alang yang luas di hulu Sungai Bahau yaitu di Long Tua dan yang lebih luas di Long Pe. Di daerah Sungai Lurah di bekas-bekas kampung perpindahan sukusuku dulu yaitu Sungai Bawang cabang Sungai Bena dan di pinggir Sungai Lurah antara Sungai Apan dan Sungai Ketawan masih terdapat alang-alang yang sering dibakar secara rutin untuk memancing binatang buruan. Pembakaran alang-alang ini tidak dilarang karena tidak mengganggu ladang. Padang alang-alang di Long Tua dipakai untuk berburu saja.

Cara orang Dayak untuk membakar padang alang-alang maupun membakar ladang adalah dengan melihat arah angin. Dengan pengetahuan mereka yang sudah turun-temurun secara tradisional, mereka melakukan pembakaran tanpa menimbulkan kebakaran hutan yang luas di sekitarnya. Jika ada yang dengan sengaja membakar hutan atau padang alang-alang tanpa musyawarah yang dapat merugikan orang lain maka orang itu didenda berdasarkan hukum adat yang berlaku. Selanjutnya mengenai hukum adat dijelaskan pada bagian lain dalam tulisan ini.

Pada jaman dulu jika masyarakat memanen hasil hutan seperti gaharu dan rotan dan hasil hutan lainnya juga ada aturan adat. Sebelum memanen hasil hutan mereka melakukan upacara yang disebut bada' taro. Jika tidak melakukan upacara ini maka tidak boleh memanen hasil hutan. Cara memanen hasil hutan tersebut juga memperhatikan kelestarian hasil. Misalnya dalam memanen rotan yang masih muda yang panjangnya kurang dari $5 \mathrm{~m}$ tidak boleh ditebas atau dipotong. Begitu juga gaharu yang belum ada isi tidak boleh ditebang. Upacara 
ini kurang dilakukan sekarang, cara memanen hasil hutan kebanyakan dituangkan dalam hukum adat tentang tana' ulen (selanjutnya dijelaskan pada bagian upacara).

\section{B. HUTAN SEBAGAI TEMPAT UNTUK MENGAMBIL BAHAN-BAHAN UPACARA DAN KEBUDAYAAN}

\section{Bahan Upacara}

Masyarakat Dayak di sekitar TN Kayan Mentarang banyak mengambil bahan-bahan yang berasal dari hutan sebagai bahan upacara. Setiap rumah tangga per desa memakai rata-rata dua sampai enam jenis bahan upacara pada tahun 1995-96. Dari jenis-jenis tersebut sekitar $44 \%$ sampai $64 \%$ dipanen dari hutan liar. Keperluan terhadap bahanbahan upacara mulai berkurang sejak masuknya agama Kristen, khususnya di daerah Sungai Bahau sekitar tahun 1957 sampai 1973. Sebelum tahun 1957 masyarakat masih ngadet, yaitu memiliki kepercayaan sendiri berdasarkan adat. Sejak tahun 1957 beberapa kampung mulai memeluk agama Kristen, kemudian pada tahun 1973 hampir setiap warga sudah memeluk agama Kristen.

Walaupun mereka telah beragama Kristen namun peninggalan kepercayaan yang dulu, masih ada sampai sekarang dan masih sangat berguna terutama di saat-saat ada kejadian atau peristiwa yang tidak dapat dipecahkan berdasarkan agama dan jauh dari pertolongan dokter. Kepercayaan terhadap adanya hantu dan roh jahat masih ada sampai sekarang. Untuk mengusir roh-roh jahat dan makhluk halus serta penangkis hantu digunakan beberapa jenis tumbuh-tumbuhan yang berasal dari hutan. Tumbuh-tumbuhan yang masih sering dipakai dalam kehidupan sehari-hari contohnya adalah sekau (Aquilaria beciariana, dan A. malaccensis), pa'ung lung (Homalomena cordata), kerenga'(Acarus calamus), simang (sejenis pohon, tidak diketahui). Beberapa jenis tumbuhan ini sering dipakai bekal jika masuk hutan untuk menghilangkan rasa takut. Apabila ada rasa takut bahan-bahan ini dibakar, baunya harum. Ada juga orang yang menaruh bahan ini di gendongan bayi atau di ayunannya agar bayi terlindung dari 
pengaruh setan. Semua jenis tumbuhan ini dimanfaatkan dari dulu dan merupakan tumbuhan asli Kalimantan, namun sekarang kebanyakan sudah ditanam di halaman atau di kebun.

Sebelum masyarakat memeluk agama Kristen ada upacara adat yang dilakukan untuk berdoa setelah memanen hasil hutan, mendoakan hasil panen, merayakan kepala yang dipotong, serta membuang sial dan cuci kampung. Upacara ini disebut melaki, artinya suatu kepercayaan terhadap burung pelaki (Haliastur indus). Sebelum mengenal Tuhan Yesus, Dewanya orang Kenyah adalah Jalung Peselong Luan, pencipta dunia. Orang menyembah dia dan percaya dia melalui binatang, seperti: uca' ano (Muntiacus muntjac), isit (Arachnothera longirostra), ukeng (Sasia abnormis), pelaki (Haliasturindus), suwi payau (Meiglyptes tukki), dan lain-lain. Lewat binatang-binatang itulah pesan dari Tuhan disampaikan kepada manusia.

Ada beberapa cara orang melakukan upacara melaki berdasarkan tujuannya serta suku yang melakukannya. Upacara melaki yang dilakukan dengan tujuan untuk memanen hasil hutan disebut bada' taro. Orang tidak boleh memetik hasil hutan tertentu apabila tidak melakukan upacara bada' taro. Setelah melakukan upacara ini baru hasil-hasil hutan yang diinginkan boleh diambil seperti: uwai (semua jenis rotan), da'a (Pandanus kaida), dan suling (Glochidion arborescens). Upacara melakiyang dilakukan dengan tujuan untuk mendoakan hasil panenan disebut malan uman biasanya dilakukan oleh seorang paren (bangsawan) dibantu oleh seorang panyen (orang biasa). Upacara ini biasanya dilakukan setelah nu'gan (tanam padi) berulang-ulang setiap bulan sampai selesai potong padi. Selama itu orang yang malan (pantangan bagi pelaku upacara) tidak boleh potong rambut. Setelah selesai potong padi baru upacara ini selesai dan orangnya boleh potong rambut. Upacara melaki yang dilakukan dengan tujuan untuk membuang sial disebut muwe'leppo' atau cuci kampung. Bahan yang digunakan untuk melakukan upacara melaki adalah nyanding, tilo iyap (telor ayam), iyap (ayam), dan sin bu'in (daging babi peliharaan). Ada juga beberapa subsuku Dayak di beberapa kampung mengatakan bahwa melakijuga bisa dilakukan untuk menyembuhkan orang sakit. Sedangkan beberapa subsuku yang 
lain di kampung lainnya mengatakan bahwa untuk menyembuhkan orang sakit dilakukan upacara yang disebut belian.

Cara melakukan upacara melaki untuk menyembuhkan orang sakit adalah sebagai berikut: Ada suatu tempat khusus di gunung sebagai tempat suci untuk melakukan upacara melaki. Upacara melaki dilakukan oleh seorang dukun atau pawang paren dibantu oleh seorang panyen, sedangkan orang di kampung tidak boleh pergi ke luar rumah. Mereka yang pergi ke luar kampung membawa parang, tombak, beras, panci untuk masak di hutan. Kalau ke sana harus melangkahi batas antara kampung dengan tempat suci itu, berupa tanda silang dari batang nyanding dengan baca-baca (doa-mantra) oleh dukun. Orang yang pergi ke gunung itu membawa satu ekor ayam, lemak babi, dan daging untuk dimakan oleh burung pelaki. Barang-barang ini diletakkan di dalam tempat khusus yaitu belanyat beta. Anak-anak membawa beras yang direndam di dalam air.

Sebelum memotong ayam, dukun tersebut memanggil burung pelaki dengan membaca mantra sambil memutar-mutar tangan ke atas. Mantranya sebagai berikut: "Oo bali pelaki, nai na nggin udip, udip dado, udip co', udip tiga, udip magad", artinya: "Ya, Tuhan melalui burung pelaki, datanglah membawa hidup, umur panjang, hidup baik, hidup bersemangat". Mantra ini dibaca berulang-ulang sampai burung pelaki datang. Burung akan terbang memutar-mutar di atas tempat melakukan upacara ini. Ada isyarat yang diberikan oleh burung pelaki tersebut, apabila terbangnya berputar berlawanan dengan permintaan dukun maka orang sakit yang sedang didoakan tersebut akan meninggal. Apabila terbangnya sesuai dengan permintaan dukun maka orang sakit tersebut akan sembuh.

Kalau burung pelakinya sudah datang lalu diberi makan. Ayam dipotong ditusuk kepalanya lalu ditancapkan di situ dan diberi lemak babi, daging, dan beras. Batang nyanding dipotong kemudian dipukul-pukul sampai hancur lalu diletakkan di bawah ayam yang dipotong supaya darah ayam menetes di batang nyanding. Orang memanggil berteriak-teriak, “'ma', ma”. Siapa yang mengambil nasi itu diolesi darah dari nyanding tersebut. Badan ayam dibawa pulang untuk dibuat bubur. Di kampung dipotong babi untuk memberi makan orang banyak di rumah orang yang sakit. Orang-orang tidak 
boleh mandi sebelum dukun menentukan boleh mandi. Ada pertanda yang dipakai untuk menentukan sudah boleh mandi atau belum, yaitu belanyat beta yang dipakai ke gunung tadi tidak boleh dibawa masuk ke dalam rumah, tetapi disimpan di luar rumah. Apabila belanyat beta ini sudah hilang (mungkin dibawa oleh dukunnya ke sungai untuk mandi) maka orang sudah boleh mandi. Hanya dukunnya yang boleh mandi pertama kali. Kalau ini dilanggar bisa membawa sial. Ada juga cara lain, apabila anak-anak sudah kepanasan dan bosan menunggu, mereka datang mengecek belanyat beta ini. Kalau belanyat ini masih ada, maka mereka membawa air di dalam bambu untuk membasahi kepala dukun tersebut. Apabila dukun sudah keramas dengan air tersebut maka anak-anak sudah boleh mandi.

Upacara belian dilakukan untuk menyembuhkan orang sakit apabila hanya ada satu orang saja yang sakit. Bahan yang dipakai adalah bete (belum diidentifikasi), nyanding (Etlingera elatior), tubo (= tubo bunyau, =pula suwi tak, tumbuhan parasit belum diidentifikasi), udu tukak (Phyllanthus urinaria), dan sengangang (Mustela nudipes). Apabila orang yang sakit banyak jumlahnya dan biasanya banyak terjadi orang meninggal di kampung itu, keadaan ini disebut layu, maka dilakukan upacara yang disebut mendeng long. Bahan yang digunakan adalah pa'ung lung (=lung adek. Homalomena cordata) ditaruh di pagar sekeliling rumah. Orang dulu memakai rumah panjang yang berpagar. Upacara ini biasanya dilakukan tiga hari. Selama melakukan upacara ini semua orang tidak boleh keluar rumah. Semua makanan dan air disiapkan sebelumnya.

\section{Bahan Kebudayaan}

Berbagai jenis kebudayaan yang berasal dari berbagai suku yang terdapat di sekitar TN Kayan Mentarang diwariskan secara turuntemurun. Kebudayaan yang beraneka ragam ini cenderung berkaitan dengan kehidupan alami di hutan. Barang-barang yang paling umum dibuat sampai sekarang adalah: tapung da'a (topi) dibuat dari daun da'a (Pandanus kaida) dihiasi dengan bulu burung teba'un (Rhinoplax irgil) (lihat Foto 24) dan temengeng (Buceros rbinoceros), udeng (anting- 
Foto 24. Anting-anting dari kepala burung teba'un

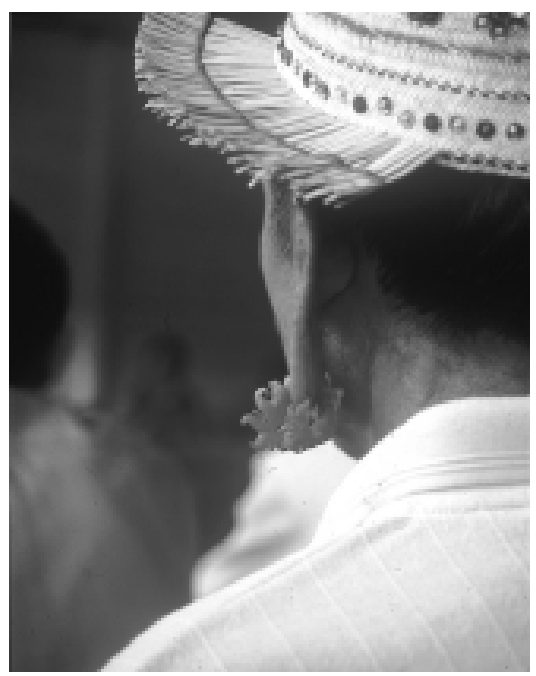

anting) dibuat dari kepala teba'un (Rhinoplax igil), sambe'(alat musik) dibuat dari jenis kayu adau (Elmerrillia mollis) dan njau lutung (Dyera costulata), dan sapai talun (baju yang dibuat dari kulit kayu) dibuat dari jenis-jenis pohon talun dengeng (Artocarpus elasticus), dan talun temai (Artocarpus altilis). Barang-barang kebudayaan ini dipakai sewaktu ada upacara-upacara penting seperti pesta pernikahan, pesta perpisahan, kunjungan pejabat penting negara, dan tahun baru.

Bahan-bahan untuk membuat barang-barang kerajinan untuk kebudayaan ini sebagaimana telah dijelaskan di atas berdasarkan sumber bahan bakunya, jumlah jenis yang dipanen per desa per KK, serta prosentase pengambilannya di hutan liar. Khususnya bahan untuk sapai talun (lihat Foto 25a dan 25b) rata-rata ada satu jenis tumbuhan untuk membuat kain dari kulit kayu yang dipanen per rumah tangga di Long Alango pada tahun 1995-96, sedangkan untuk desa Apau Ping dan Long Pujungan tidak ada yang panen. Jenis-jenis tumbuhan tersebut $100 \%$ dipanen dari hutan liar. Sedangkan jenis kayu yang digunakan sebagai bahan pewarna adalah seleman (Weinmannia blumei) dan suling (Glochidion arborescens). Bahan pewarna 
untuk lukisan, pewarna kain, dan cat tapan dipanen sekitar empat sampai lima jenis per rumah tangga per desa (lihat Foto 26). Dari jenis tersebut $98 \%$ sampai $100 \%$ berasal dari hutan liar.

Foto 25. Kulit kayu talun dipakai untuk membuat pakaian tradisional di L. Alango (25a dan 25b)

(a)

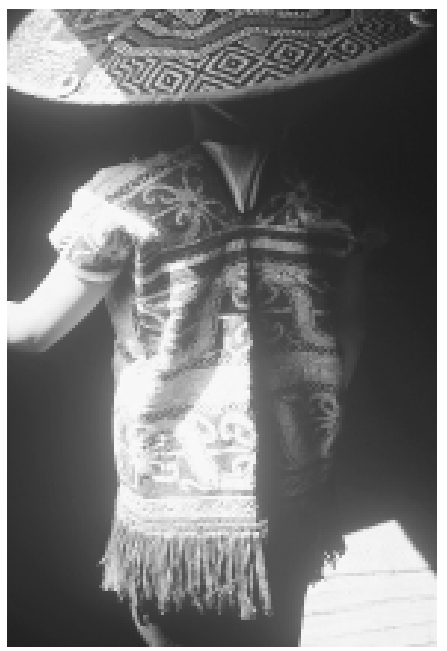

(b)

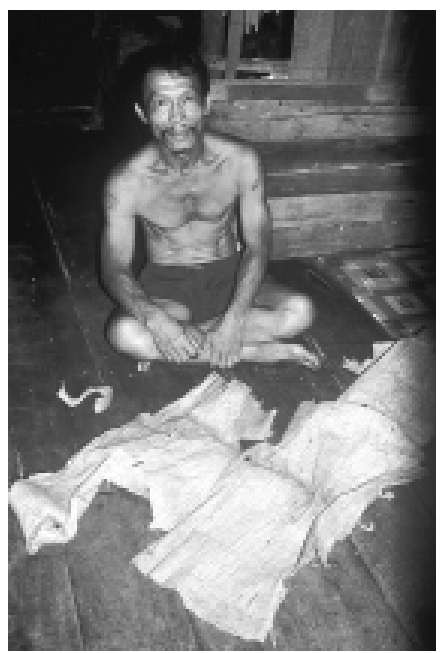

Foto 26. Kayu ainguntuk membuat pewarna (Apau Ping)

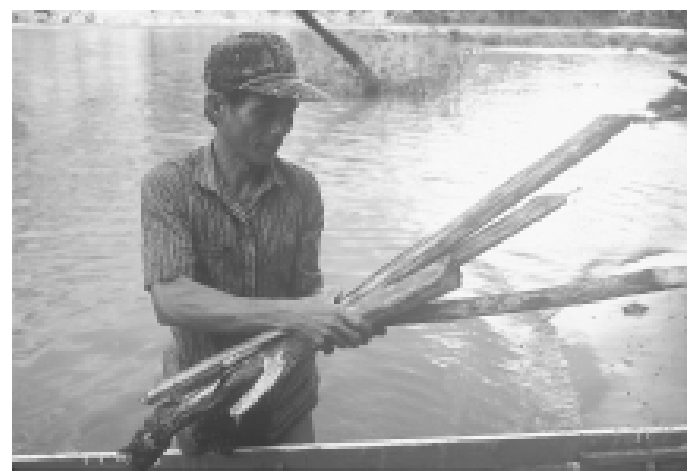




\section{Tari-tarian dan Lagu-lagu Meniru Kehidupan di Hutan}

Untuk kebudayaan kesenian berupa tari-tarian digunakan pakaian khusus. Pakaian yang digunakan oleh laki-laki disebut besunung yaitu baju yang dibuat dari kulit binatang (lihat Foto 27). Kulit binatang yang sering digunakan untuk orang dewasa adalah kule lenjau (Pardofelis nebulosa), kule bilung (Pardofelis marmorata), buang (Helartos malayanus), dan iko temengang (ekor Buceros rhinoceros) dianyam sedemikian rupa untuk menghiasi baju. Untuk anak-anak dibuatkan besunung dari kulit bangat (Presbytis hosei) sebab kulit binatang ini kecil. Sedangkan wanitanya memakai pakaian dengan hiasan dari manik-manik saja disebut ta'a. Pada jari tangan mereka memakai kirip yaitu sayap burung teba'un (Rhioplax igili) yang diikatkan di jari tengah, dipakai oleh laki-laki maupun perempuan (lihat Foto 28). Selain itu juga memakai topi yang dihiasi bulu burung. Topi untuk laki-laki disebut tekeleng dihiasi ekor burung teba'un. Untuk topi wanitanya disebut tapung puk dihiasi bulu burung temengang saja.

Foto 27 . Penari yang pakai besunung

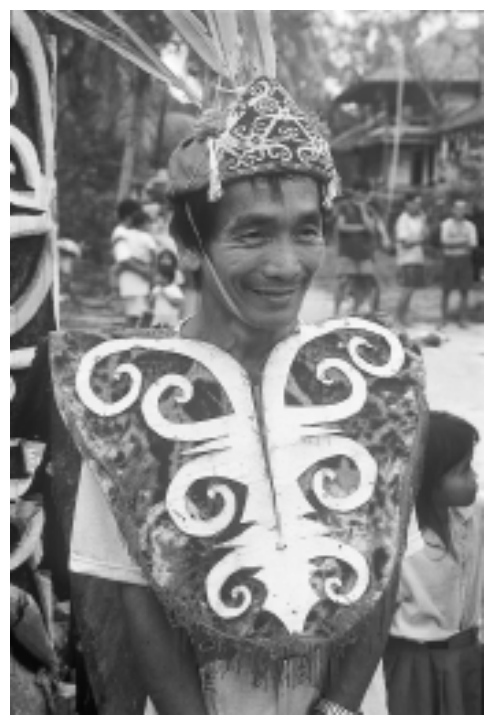


Foto 28. Penari yang pakai topi dari bulu burung teba'un dan temengang

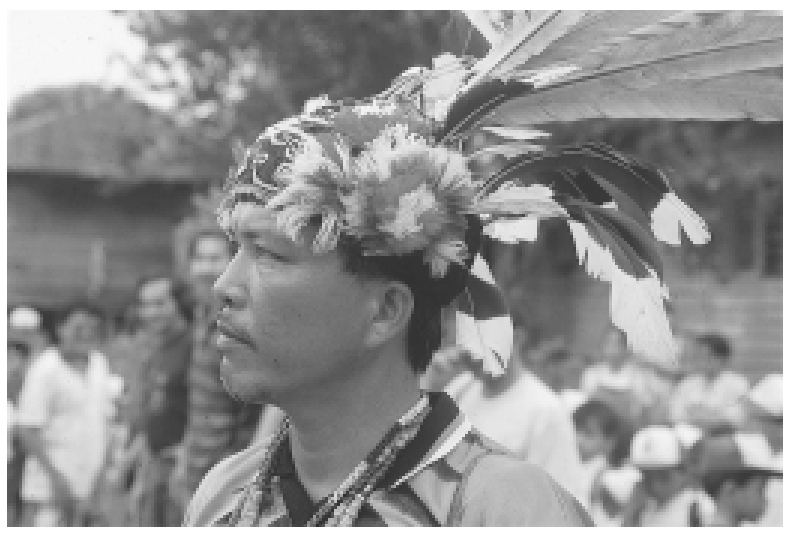

Ada tari-tarian untuk wanita yang menirukan burung kuwai (Argusianus argus) dan temengang (Buceros rhinoceros). Untuk laki-laki tariannya seperti minjung (berburu burung), meleput (berburu dengan sumpit), ngejala (menjala ikan). Tari-tarian ini diiringi oleh musik sambe'(semacam gitar) dan lagu-lagu yang mengalun indah. Lagu yang dilantunkan secara bersahut-sahutan juga biasanya berkaitan dengan kisah sesuatu di alam, misalnya lagu tentang burungburung kesayangan atau burung peliharaan yang berjudul kulung kuwai (Argusianus argus), kulung punai (Treron currirostra), kulung kuju (Egretta egret), kulung nyakilang (Colocalia esculenta). Tari-tarian yang lain misalnya pepatai yaitu tari perang untuk mempertahankan wilayah atau berebut wanita.

\section{SIMBOL STATUS SOSIAL DAN NAMA-NAMA ORANG DAYAK MENGAMBIL CONTOH DARI HUTAN}

Dalam kehidupan masyarakat Dayak banyak menggunakan simbolsimbol yang berasal dari hutan. Simbol-simbol ini biasa terdapat dalam lukisan, ukiran, dan anyaman pada benda-benda yang menjadi ciri khas kebudayaan Dayak. Ukiran yang terdapat pada sarung mandau, ukiran pada mandaunya, ukiran pada perahu, anyaman manik-manik yang terdapat pada bening (gendongan bayi), saung seling, belanyat 
dan lain-lain merupakan simbol status sosial dan kekayaan. Di tempattempat umum misalnya balai desa, balai pertemuan umum, ruang tunggu di lapangan terbang dan di tempat-tempat umum lainnya dapat dijumpai lukisan di dinding dengan simbol-simbol dari hutan atau alam. Di lapangan sepakbola di kampung biasanya terletak di depan balai pertemuan umum, terdapat tiang yang disebut tilang berukir burung temengang dan ila'. Di depan perahu di bagian hulunya yang disebut julung (kepala perahu) biasa terdapat ukiran naga.

\section{Simbol Status Sosial}

Simbol-simbol yang berasal dari hutan yang digunakan oleh orang Dayak antara lain: burung temengang (Buceros rhinoceros), teba'un (Rhinoplax irgil), kabuk (Varanus rudicollis) (lihat Foto 29a dan 28b), kule lenjau (Pardofelis nebulosa), kule bilung (Pardofelis marmorata), baya'(Crocodylus porosus), lengunan (naga), sapuk (bunga), dan lainlain. Menurut adat dalam status sosial, orang paren (bangsawan) menggunakan simbol tertentu di mana orang panyen (orang biasa) seharusnya tidak boleh memakainya. Tetapi sistem ini mulai berubah sekarang, pemakaian simbol-simbol ini mulai bercampur. Orang panyen sering memakai simbol yang seharusnya hanya dipakai oleh orang paren. Dulu orang yang melanggar tersebut didenda, tetapi sekarang ini tidak ada lagi larangan ataupun denda.

Simbol yang dipakai oleh orang paren misalnya temengang, kule lenjau, dan kabuk, simbol ini biasa terdapat pada gendongan bayi. Simbol untuk orang panyen yaitu kalung nyain (ukiran polos), atau pendeng (seperti ikat pinggang berhiasan bunga). Ukiran yang terdapat pada mandau ataupun pada sarungnya biasanya gambar kabuk untuk paren dan untuk panyen biasa polos saja. Mandau juga merupakan simbol kekayaan. Makin banyak seseorang memiliki mandau maka semakin kaya lah orang tersebut. Ada juga yang menggunakan gambar orang "ila" (ukuran manusia), tergantung asalusul keturunan bangsawan tersebut. Gambar ila'yang paling banyak digunakan adalah pada saung seling yaitu sejenis topi lebar lambang bangsawan. 
Foto 29. Kabuk di (a) balai desa dan (b) mandau

(a)

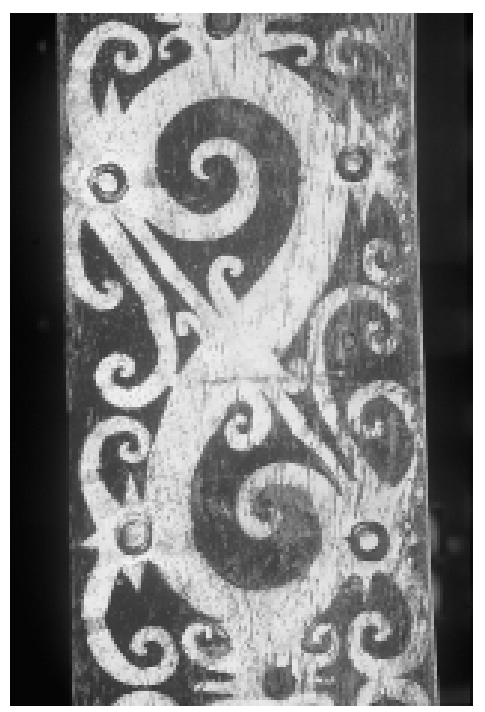

(b)

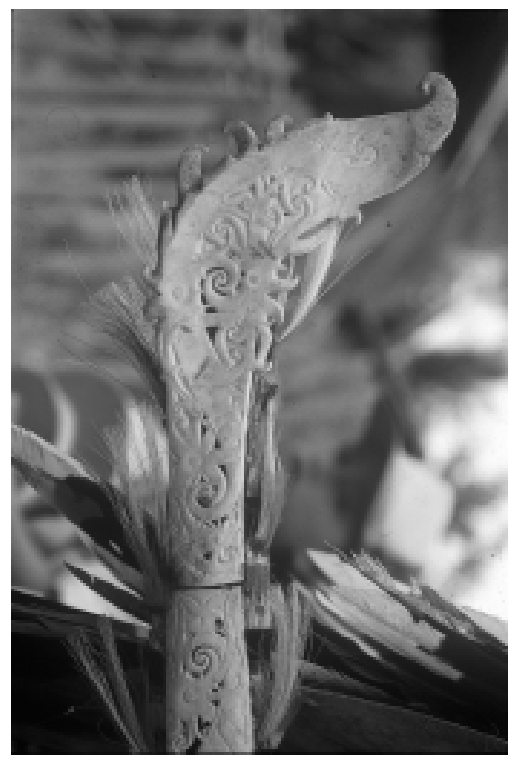


Gigi binatang seperti kule lenjau (Pardofelis nebulosa), kule bilung (Pardofelis marmorata), buang (Helartos malayanus), dan ba'bui (Sus barbatus) dipakai untuk hiasan ba'(Leppo' Ma'ut=gendongan bayi) yaitu alat untuk menggendong bayi. Di bagian luar dari bening ini gigi dari binatang ini digantung sebagai hiasan. Orang tidak boleh sembarang menggunakan gigi binatang tersebut Hanya paren bio' (bangsawan besar) yang boleh memakai gigi kule lenjau yaitu paren dari Leppo' Kulit dan Leppo' Jalan. Sedangkan paren dari leppo'yang lain, mereka tidak berani memakainya untuk hiasan di gendongan bayi. Kalau paren dari leppo'yang lain, mereka hanya boleh pakai gigi kule bilung saja. Walaupun mereka punya gigi kule lenjau biasanya mereka hanya memakai kalung pada waktu tahun baru atau pesta saja. Orang panyen tidak boleh memakai gigi kule. Orang panyen hanya boleh pakai gigi buang dan ba'bui yaitu satu baris saja sebanyak enam buah tidak boleh lebih, diletakkan di bawah. Kalau orang paren boleh memakai sampai empat baris sebanyak 24 buah. Kalau mereka sembarangan memakai gigi kule, mereka takut kena parip (sial) yaitu anak sakit-sakitan atau anak bisa meninggal. Hal ini sangat mereka percayai, sebab dulu masyarakat pernah membuktikan bahwa ada orang yang sembarangan memakai gigi ini sebagai hiasan gendongan bayi, lalu anaknya meninggal berturut-turut. Setelah gigi kule ini dilepas baru anak berikutnya dapat bertahan hidup sampai dewasa.

Ada kecenderungan sekarang pemakaian gigi-gigi yang berasal dari alam mulai berkurang karena sulit mendapatkan gigi kule lenjau, kule bilung, dan gigi buang. Sebagai penggantinya digunakan gigi palsu yang berasal dari pabrik dan sudah banyak diperjualbelikan. Oleh karena mudah mendapatkannya maka orang semakin bebas saja membeli dan memakainya. Di samping itu melemahnya adat menyebabkan orang juga secara sembarangan menggunakan simbolsimbol ini sekarang. Mereka mulai bercampur memakai simbol ini, alasannya karena mereka sudah masuk agama Kristen. Walaupun mereka sekarang mampu membeli gigi yang asli peninggalan dari orang paren tetapi gigi tersebut sulit dicari karena jumlahnya sedikit. Selain itu binatangnya sekarang semakin langka. Mereka membeli gigi yang palsu dan membuat gambar kabuk, baya' atau ila'dengan manik-manik pada alat gendongan bayinya, namun demikian mereka 
yang tahu aturan adat dan parip (akibat yang menyebabkan sial) tetap tidak berani menggunakan gigi yang asli.

Pemakaian simbol-simbol ini sekarang semakin bercampur, namun tetap dapat dibedakan antara paren dengan panyen. Mereka yang memakai gendongan bayi dengan gambar kabuk atau ila'tetapi payungnya dari daun sang atau sa'ung sang yang dihiasi dengan kain dari toko (payung kain dari toko), maka artinya mereka adalah panyen. Apabila ada orang yang memakai simbol dari kabuk atau ila' dan memakai saung seling (topi peninggalan nenek moyang dari dulu) atau saung eko (topi yang berhiasan bulu temengang) tetapi tidak memakai gigi asli atau hanya gigi buang atau gigi kule bilung, artinya ia adalah orang panyen tiga. Sedangkan mereka yang memakai simbol kabuk, baya', atau ila'memakai gigi asli dari kule lenjau dan dia juga memakai saung seling atau saung eko, maka mereka adalah paren bio'. Orang paren bio' juga boleh memakai gigi binatang yang lain seperti kule bilung atau buang.

\section{Nama-nama Orang Dayak Diambil Dari Nama Binatang dan Tumbuhan Berdasarkan Status Sosial}

Selain simbol status sosial yang telah disebutkan di atas nama-nama orang Dayak juga ada yang diambil dari nama binatang dan tumbuhan. Contohnya ${ }^{18}$ : Kule (nama umum dari macan), Bilung (macan kecil), Lenjau (macan yang besar), Baya' (buaya), Ngang (burung yang paling besar), Ba'un, (burung teba'un), Tu'ban (ekor burung teba'un yang sudah dipakai sebagai hiasan topi), Kirip (sayap burung tebaun yang dipakai hiasan menari), Punai (sejenis burung), Merang (sejenis kayu yang keras), Ulin (sejenis kayu yang paling keras), Suling (sejenis kayu untuk pewarna), Jangin (nama jenis tumbuhan), Adau (sejenis tumbuhan untuk kayu bangunan), Lirang (tumbuhan obat), Limbang (tumbuhan obat), Pai (tumbuhan sejenis rengas), Ipo' (tumbuhan racun), Salo' (tumbuhan racun), Sapuk (bunga), Peu (bunga mekar), Ulem (buah sejenis terong pipit), Njuk (sejenis lengkuas), $\boldsymbol{P i n g}$ (rumput), $\boldsymbol{U d a n g}$ (sejenis ikan), kulat (sejenis jamur), dan lain-lain. 
Nama paren (bangsawan) menggunakan nama untuk lakilaki: Kule, Lenjau, Bilung, Baya', Ngang, dan Merang, dan untuk perempuan: Ba'un, Kirip, Suling, Sapuk, dan lain-lain. Untuk nama panyen (biasa) digunakan nama untuklaki-laki: Njuk, Ipo', Salo; dan untuk perempuan: Ulem, Limbang, Udang, Ping, Kulat, dan lain-lain. Nama-nama lainnya yang bukan dari binatang atau tumbuhan untuk nama paren laki-laki adalah Lawai, dan Ingan; dan untuk perempuan adalah: Bulan, Bungan, Kilet, dan Lambang. Nama panyen yang lain, untuk laki-laki adalah Dungau, Ungau, Irang, Bat, Bong, Dan, dan lain-lain. Nama orang panyen yang lain untuk perempuan adalah Bun, Uding, Usun, Long, dan lain-lain. Nama orang paren dan orang panyen tidak boleh dicampur. Orang tidak boleh sembarang membuat nama anaknya, namun harus tergantung golongannya. Orang percaya apabila orang sembarangan membuat nama anaknya, maka anaknya akan sakit-sakitan seumur hidupnya.

\section{HUTAN SEBAGAI TEMPAT BERTEDUH DAN MENCARI HIBURAN}

Di hutan orang Dayak merasa tenang dan nyaman serta merasa lebih dekat dengan Tuhan. Di dalam hutan pikiran mereka terhibur mendengar suara alam, kicau burung dan gemercik sungai yang melantunkan sabda alam. Di kala mereka merasa jenuh dengan pekerjaan di ladang maupun di rumah maka mereka masuk ke hutan untuk mencari hiburan. Kebiasaan ini sering kita dengar lewat dialog, misalnya ketika bertemu dengan seseorang atau sekelompok orang yang sedang berangkat ke hutan, lalu kita bertanya: "ke mana?", sering mereka menjawab: "cari hiburan dulu"; "di mana ?", dijawab: "ka' daya” (di hulu sungai, maksudnya di hutan), dan sebagainya. 


\section{Bab 4 \\ Pengaturan Hutan Berdasarkan Hukum Adat Secara Lokal}

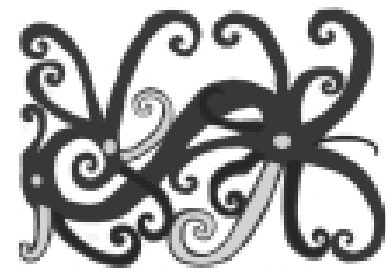

Pemanfaatan hutan yang dijelaskan di atas diatur sejak turun-temurun dengan hukum adat. Hukum adat untuk mengatur pengelolaan hutan mencerminkan ketergantungan masyarakat pada hutan, misalnya adalah tana' ulen. Hukum adat yang berlaku dari dulu merupakan hukum adat yang tidak tertulis. Sedangkan hukum negara merupakan hukum tertulis. Kadang-kadang hukum adat dan hukum negara saling mengisi, tetapi kadang-kadang terjadi konflik juga, misalnya tentang penggunaan hutan, batas taman nasional yang dibuat berdasarkan hukum negara lain dan tidak memperhatikan batas hutan adat yang ditentukan masyarakat secara turun temurun. Hukum adat dan hukum negara seharusnya saling mengisi ${ }^{20}$, yakni apabila hukum adat belum mengatur, maka hukum negara yang mengaturnya. Sebaliknya apabila dalam hukum negara tidak ada, maka hukum adat yang mengaturnya. Apabila kedua-duanya ada pengaturannya maka yang diutamakan lebih dulu adalah pengaturan hukum adat, karena hukum adatlah yang lebih sesuai berdasarkan kondisi, situasi, dan pengalaman sejarahnya. 


\section{A. SIFAT HUKUM ADAT YANG TIDAK STATIS DIBUAT DENGAN SISTEM PENYESUAIAN DENGAN KEADAAN BARU}

Orang pada umumnya mengetahui adanya hukum adat secara lisan. Hukum adat mulai ditulis di Wilayah Adat Hulu Sungai Bahau oleh kepala-kepala adat sekitar tahun 1993-94. Sifat hukum adat yang tidak statis dibuat dengan sistem penyesuaian dengan keadaan baru. Sebagai contoh, peraturan adat yang dibuat di hulu Sungai Bahau selalu ditinjau kembali setiap tahunnya pada waktu Pesta Panen Gabungan dan Musyawarah Adat Besar Hulu Sungai Bahau. Aturan yang lama disempurnakan dengan cara menambah atau mengurangi pasal-pasal yang telah ada, sehingga selalu dapat menyesuaikan dengan perkembangan jaman.

Hukum adat diatur terutama oleh kepala adat di desa dan kepala adat besar. Tokoh masyarakat juga dilibatkan untuk mengambil keputusan bersama dalam desa maupun di wilayah adat tersebut. Kalau mengambil keputusan dalam desa, urusan pemerintahan, dan urusan luar secara umum didiskusikan bersama dengan kepala desa. Sedangkan kalau yang terkait dengan hutan, denda, dan urusan keluarga, ketua adat dan kepala adat besar yang bertanggung jawab terhadap keputusan itu.

Peraturan adat dalam waktu lima tahun terakhir (1993-98) telah banyak mengalami perubahan dan pembaruan, namun pasalpasal yang masih relevan masih dipakai. Contohnya, Keputusan Musyawarah Kepala-Kepala Desa dan Kepala Adat Hulu Bahau di Long Tebulo Tahun 1996 masih mengacu pada keputusan yang dibuat di Apau Ping pada tahun 1994, terutama Pasal X mengenai watas ladang ${ }^{21}$, dan Pasal XI mengenai watas desa $^{22}$, yang isinya mengenai pengaturan hasil hutan, daerah perladangan, persawahan, kayu yang dapat dimanfaatkan sebagai bahan bangunan, perahu, dan lain-lain. Keterlibatan WWF Kayan Mentarang memberikan pengaruh penting terhadap masukan-masukan dalam hukum adat pada tahun 1996, yang memiliki nilai bagi konservasi dan kesejahteraan masyarakat di sekitarnya. Dialog antara masyarakat terutama pemuka adat dan desa dengan staf WWF Kayan Mentarang mengenai dampak negatif dari 
pemanenan hasil hutan secara berlebihan, dan bahayanya penggunaan racun dan strum telah membuahkan hasil, yang kemudian dapat dimuat dalam hukum adat secara tertulis.

\section{B. HUKUM ADAT TERHADAP HUTAN}

Masyarakat telah menyadari ketergantungannya dengan hutan, maka setiap desa memiliki aturan pemanfaatan dan pengelolaan hutan. Aturan ini pada dasarnya adalah untuk mencegah konflik mengenai berbagai kepentingan dalam masyarakat. Ada aturan untuk pemanfaatan binatang, kayu-kayu, dan batas ladang, serta kepemilikan jekkau (bekas-bekas ladang).

Aturan adat untuk pemanfaatan binatang yang sudah lama diatur adalah menjaga babi berenang (ba'bui satung). Bila musim babi berenang tidak boleh menjaga jalannya di darat. Bila menangkap babi berenang tidak boleh menembak dengan senapan, hanya boleh menggunakan bujak dan parang. Tidak diperkenankan menangkap binatang dengan menggunakan ranjau (belatik) yang berbahaya. Tidak boleh menangkap ikan menggunakan strum. Belakangan ini mulai diatur pengambilan landak (settung) untuk keperluan batu settung untuk dijual karena harganya mahal. Selain itu ada juga larangan membunuh banteng (Bos javanicus), mengambil tanduk payau, dan membunuh beruang sembarangan, kecuali binatang tersebut merusak dan melawan orang yang sedang di hutan.

Pemanfaatan kayu-kayu untuk bangunan masih banyak yang belum dicantumkan dalam hukum adat tertulis. Namun umumnya ada aturan tidak tertulis yang diketahui. Contohnya: kayu-kayu yang berada di dalam hutan, apabila ada orang yang ingin memanfaatkannya di kemudian hari sebagai bahan bangunan, maka kayu itu diberi tanda pada batangnya. Biasanya setinggi dada, dengan simbol silung kelunan (muka manusia). Artinya orang lain tidak boleh mengambil pohon itu lagi selain yang memberi tanda pertama kali. Selain itu ada juga dengan cara mesip, yaitu menandai suatu pohon kayu dengan sebatang tongkat yang disisipi daun, yang ujungnya diarahkan 
menunjuk batang kayu tersebut. Ada juga yang memberi tanda di batang kayu tersebut dengan cara melukai batangnya kemudian menyisipkan daun-daun di situ. Pada perkembangan sekarang ada juga tanda yang dibuat dengan menulis nama mereka sendiri, sehingga orang lain mengetahui siapa pemilik kayu tersebut. Memberi tanda ini disebut mulen (melarang).

Untuk kayu-kayu gaharu masyarakat lokal yang ada di sekitar TN Kayan Mentarang telah memiliki sistem sendiri. Secara lisan, ada pemahaman bahwa kayu gaharu hanya boleh ditebang kalau ada aing (isi yang berwarna hitam dan harum), jika tidak ada aing tidak boleh ditebang, dibiarkan sampai ada aingnya. Alasan ini juga disebabkan untuk menebang pohon gaharu yang tidak ada isi hanya membuang tenaga percuma dan makan waktu. Alasan lain adalah masih bisa ditebang nanti kalau sudah ada isi. Biasa juga kalau pohon ditebuk (dilukai dengan parang), lama-lama ada isi aingnya.

Terhadap kepemilikan pohon-pohon buah yang ditanam diatur berdasarkan aturan lisan yang secara turun-temurun. Siapa yang menanam maka dia yang punya pohon tersebut. Sebagai contoh kasus, ada pohon buah di halaman rumah seseorang yang tinggal di hulu kampung. Orang yang tinggal di dekat pohon itu tidak boleh memetik buahnya, karena ternyata pohon buah ini dimiliki oleh orang yang bermukim jauh di hilir. Hal ini ternyata berkaitan dengan sejarah perpindahan penduduk di tempat itu. Orang yang pindah pertama kali ke sana hanya beberapa keluarga saja. Keluarga ini membuat kebun dengan menanam tanaman buah-buahan di lokasi tersebut. Kemudian ada orang lain yang baru pindah ke kampung itu, mereka minta ijin kepada yang punya kebun di situ untuk membangun rumah di sana. Apabila yang punya kebun itu memberi ijin, mereka boleh membangun rumah di sana, tetapi kebunnya masih milik orang yang menanamnya. Kalau musim buah, yang boleh memetik buahnya hanya orang yang punya, yaitu orang yang menanamnya, walaupun rumahnya jauh dari situ. Sedangkan orang yang tinggal di dekatnya tidak boleh memetiknya, apabila mereka memetik dianggap mencuri dan itu didenda. Orang yang tinggal di dekatnya boleh memungut 
buah yang jatuh, dan kalau waktunya yang punya sudah mulai panen biasanya orang yang tinggal di situ juga diberi bagian.

Aturan lain adalah mengenai larangan membakar hutan dan padang alang-alang yang telah dicantumkan dalam hukum adat, khususnya Wilayah Adat Besar Hulu Bahau, dalam Pasal IX sebagai berikut: Ayat a. Membakar hutan dengan sengaja (bukan karena harus dibakar dengan alasan perladangan) yang akibatnya merugikan orang lain dikenai denda berupa satu buah anggung jangin (gong) untuk orang yang dirugikan. Ayat b. Membakar hutan/lalang di daerah yang dapat dimanfaatkan untuk berladang sekalipun tidak mengakibatkan kerugian pada anggota masyarakat itu sendiri, misalnya pohon-pohon buah, kebun tidak ada yang terbakar tetapi merugikan masyarakat secara umum karena tanah menjadi tandus, maka tetap didenda satu buah anggung jangin. Ayat c. Kesimpulannya jika pelanggaran itu mencakup Pasal IX ayat a dan b, maka denda yang dituntut menjadi dua kali lipat, yakni dua buah anggung jangin, 1 buah diserahkan kepada pihak yang dirugikan, dan satu buah anggung dimasukkan ke dalam kas desa/adat.

Aturan tentang pengusaha hasil hutan telah dicantumkan pada Pasal XXV yang isinya sebagai berikut: Ayat a. Pengusaha-pengusaha hasil hutan dari luar daerah Hulu Bahau (sembilan desa) tidak diperkenankan memungut hasil hutan (gaharu, rotan, kayu manis, damar) secara langsung, tetapi boleh membeli dari masyarakat sebagai penampung hasil hutan dengan surat ijin dari Bupati, dan melalui Camat agar tidak terjadi kesalah ahaman antara pengusaha dengan masyarakat desa Hulu Bahau. Ayat b. Pengusaha hasil hutan asal putera daerah yang sudah pindah ke daerah lain tidak diperkenankan menjalankan usaha hasil hutan dengan jumlah banyak terkecuali bergabung dengan masyarakat dan diberi waktu terbatas, (satu sampai dengan tiga orang). Ayat c. Namun asal putera daerah jika rombongannya lebih dari tiga orang tidak diberi ijin masuk di hutan untuk mengusahakan kayu gaharu karena tamu-tamu dari luar daerah tidak memelihara kayu gaharu/rotan dll. yang ada di hutan malahan merusak habis-habisan kayu gaharu yang belum pada waktunya 
ditebang. Ayat d. Pengusaha hasil hutan yang masuk langsung di dalam hutan dan di dalam wilayah desa Hulu Bahau tanpa ijin dikenai denda satu orang Rp. 250.000 dimasukkan ke dalam kas adat. Ayat e. Pengusaha hasil hutan yang melalui ijin dan terpaksa karena kebijaksanaan, (paling banyak satu rombongan lima orang) harus menyumbang uang sebesar Rp. 500.000 terlebih dulu kepada desadesa yang bersangkutan, barulah boleh masuk untuk berusaha dan batas waktu dapat dirundingkan dengan kepala desanya.

Untuk pengaturan batas ladang dan jekkau dibuat kesepakatan sewaktu orang mulai membuka hutan rimba pertama kali. Sebelum mulai membuka hutan diadakan rapat di desa yang dihadiri oleh seluruh masyarakat. Setelah lokasi ditentukan dan disepakati bersama maka besoknya diberi tanda dan dibuat batasbatas (biasanya pohon-pohon) yang harus dikerjakan masing-masing. Menebas ladang bisa dilakukan dengan senguyun (pertukaran hari tenaga kerja), ada juga yang dikerjakan sendiri. Aturan mengenai batas ladang telah dicantumkan dalam hukum adat tertulis, yaitu Pasal X (lihat catatan kaki no. 21). Sedangkan pengaturan mengenai jekkau (bekas ladang) belum dimasukkan dalam hukum tertulis. Melalui hukum adat lisan, misalnya orang tertentu ingin memanfaatkan jekkau milik orang lain, mereka boleh pinjam untuk beberapa tahun tetapi harus minta ijin. Jekkau adalah hak milik orang yang membuat ladang pertama kali di tempat tersebut dengan membuka hutan rimba.

\section{TANA'ULENDI HULU BAHAU}

\section{Konsep Tana'Ulen}

Salah satu unsur penting dalam hukum adat berkaitan dengan pemanfaatan dan pengelolaan hutan adalah konsep tana' ulen. Tana' ulen atau sungai ulen ${ }^{2}$ adalah suatu kawasan hutan rimba yang dilindungi secara adat. Wilayah tana' ulen meliputi satu sungai atau beberapa sungai kecil mulai dari muaranya sampai ke ujung-ujung 
anak sungai di titik mata airnya. Batas-batas tana' ulen meliputi punggung-punggung gunung di mana sungai tersebut mengalir.

Di dalam wilayah tana' ulen orang dilarang menebang pohon, membakar hutan, membuat ladang, dan kegiatan yang menimbulkan kerusakan hutan. Pengambilan hasil hutan di dalam tana' ulen diatur hanya untuk memanfaatkan beberapa jenis hasil hutan tertentu saja. Hasil hutan yang boleh diambil dari tana' ulen antara lain: gaharu, rotan, kayu manis, buah-buahan, ikan, dan binatang. Tana' ulen hanya dimanfaatkan pada waktu-waktu tertentu untuk kepentingan umum apabila ada kegiatan di desa. Pengambilan hasil hutan dalam wilayah tana' ulen ditentukan berdasarkan hasil musyawarah bersama seluruh masyarakat atau pemuka-pemuka desa yang meliputi seluruh aparat desa antara lain kepala desa, kepala adat di desa, dan kepala adat besar.

Pengaturan cara pemanenan hasil hutan di dalam tana' ulen apabila ada kesepakatan untuk memanennya, orang tidak diperkenankan mengambil secara sembarangan dan merusak hasil hutan yang ada di dalamnya. Contoh untuk pengambilan rotan, tidak boleh memotong batang yang masih muda yang panjangnya belum cukup untuk dapat dimanfaatkan.

Pengambilan untuk kepentingan pribadi hanya boleh apabila diberi ijin berdasarkan keputusan kepala adat hasil musyawarah. Orang yang masuk mengambil hasil hutan dikenai cukai per orang. Jumlah cukai ini bisa kecil, misalnya Rp. 20.000 atau besar, Rp. 200.000, berdasarkan nilai hasilnya, lama bekerja dan ditetapkan berdasarkan peraturan. Cukainya biasanya dibayar kepada kepala adat atau kepala desa dan seharusnya, dipakai untuk kas adat. Peraturan untuk orang yang berasal dari penduduk setempat (orang asli) berbeda dengan peraturan untuk orang pendatang (= kelunan alo'yaitu orang yang berasal dari luar daerah). Umumnya peraturan yang ditetapkan untuk penduduk asli setempat lebih longgar, kadang-kadang masih boleh mengambil untuk keperluan sehari-hari apabila tidak ada hasil di tempat lain. Sedangkan orang dari luar sama sekali tidak diperbolehkan. 


\section{Asal Usul Konsep Tana' Ulen}

Asal usul tana' ulen semula hanya dimiliki oleh para bangsawan (paren) di Long Alango, Long Uli, dan Long Pujungan. Tana' ulen Long Alango semula dimiliki oleh Kepala Adat Besar Hulu Bahau Apui Njau sekitar tahun 1925 sampai 1967 (sejak jaman penjajahan Belanda sampai Indonesia merdeka). Tana' ulen yang diklaim meliputi daerah aliran sungai (DAS) Nggeng. Tana' ulen desa Long Uli meliputi wilayah Sungai Lutung. Sedangkan tana'ulen desa Long Pujungan meliputi Sungai Ahan.

Sewaktu Apui Njau menjadi Kepala Adat Besar Hulu Bahau, orang dilarang memasuki tana' ulen di Sungai Nggeng, konon muara sungai dijaga ketat. Siapa yang berani melewati batas yang telah diberi tanda maka orang tersebut disumpit. Apui Njau sangat ahli meniup sumpit. Menurut cerita dari mulut ke mulut, beliau mengeluarkan pernyataan, "Siapa yang berani masuk ke dalam wilayah tana' ulen, awas!" Sehingga tidak ada orang yang berani datang ke sana pada waktu itu. Setelah beliau wafat pada tahun 1967, penjagaan tana' ulen mulai cenderung berkurang, sampai akhirnya tana' ulen ditetapkan menjadi tana' ulen desa.

Pada tahun 1980 pemerintah Indonesia menetapkan wilayah yang meliputi hulu-hulu Sungai Kayan sampai Sungai Mentarang sebagai cagar alam berdasarkan SK Menteri Pertanian No. 847/Kpts/ Um/II/1980, seluas 1.360 .500 ha. Penunjukan kawasan cagar alam ini sebagai realisasi atas kecaman dunia internasional terhadap pemerintah Indonesia bahwa Indonesia merupakan negara perusak hutan tropis melalui kegiatan $\mathrm{HPH}$, perkebunan, transmigrasi, dan konversi untuk berbagai kepentingan. Setelah penetapan status cagar alam tersebut, kemudian pada tahun-tahun berikutnya diadakan beberapa survei untuk menggali informasi. Sekitar tahun 1990 Ditjen PHPA bekerjasama dengan WWF Indonesia dan Lembaga Ilmu Pengetahuan Indonesia (LIPI) melakukan kegiatan untuk penyusunan rencana pengelolaan kawasan Kayan Mentarang. WWF dan LIPI melakukan survei di dalam Cagar Alam Kayan Mentarang. Hasil dari survei tersebut menunjukkan bahwa keberadaan masyarakat Dayak 
perlu diperhatikan dan ketergantungannya terhadap hutan sangat tinggi, dan apalagi ada keterkaitan budaya masyarakat Dayak terhadap hutan. Hasil yang penting lainnya adalah bahwa masyarakat Dayak telah memiliki aturan untuk mengelola hutan secara lokal. Ada buktibukti yang menunjukkan bahwa orang Dayak telah mengelola hutan selama berabad-abad namun tidak menimbulkan kerusakan terhadap hutan. Oleh sebab itu pengelolaan hutan dengan sistem adat yang berkaitan dengan perlindungan hutan dan konservasi diangkat untuk dijadikan sistem pengelolaan secara lokal. Maka pada waktu itu, sekitar tahun 1992 sampai 1994, WWF dan Camat Pujungan menyarankan agar setiap desa memiliki tana' ulen. Sehingga setiap desa kemudian mengklaim wilayah tana' ulen masing-masing dengan arti lebih luas daripada yang aslinya.

Pada tahun 1994 status cagar alam diusulkan untuk dirubah menjadi taman nasional, berdasarkan hasil-hasil survei oleh tim dari Instansi Pusat, Pemda Tingkat I dan II, WWF, dan PT. Giri Ekawana, yang menyimpulkan bahwa keberadaan masyarakat di sekitar cagar alam penting diperhatikan, maka diusulkan agar status cagar alam dirubah menjadi taman nasional. Akhirnya pada tanggal 7 Oktober 1996 Cagar Alam Kayan Mentarang dirubah status menjadi Taman Nasional Kayan Mentarang berdasarkan SK Menteri Kehutanan No. 631/Kpts-II/1996. Dengan status taman nasional, masyarakat di dalam dan di sekitar wilayahnya bisa tetap tinggal disana dan menggunakan sumber daya alam yang tertentu, sesuai peraturannya. Kalau masih cagar alam, wilayahnya tidak boleh digunakan sama sekali oleh orang setempat.

Untuk melindungi kawasan TN Kayan Mentarang dan hutan bagi kepentingan masyarakat Dayak terhadap ancaman kerusakan dari luar, maka hal ini dilakukan dengan mempertahankan dan memperkuat status hukum wilayah hutan di daerah perbatasan taman nasional. Wilayah hutan di daerah perbatasan ini sebagian besar adalah hutan adat dan wilayah desa-desa yang berada di sekitar taman nasional. Kemudian bersama-sama dengan WWF dilakukan pemetaan wilayah desa secara partisipatif dari tahun 1993 sampai 1998. Pemetaan desa partisipatif bertujuan untuk mengetahui batas-batas 
desa dan wilayah hutan (dan sumber lain) yang mau dilindungi oleh masyarakat, seperti konsep tana'ulen yang asli. Semua desa di Sungai Bahau yang ada kaitan dengan TN Kayan Mentarang sudah dipetakan.

Menurut masyarakat, untuk menjaga keadaan hutan dan melindungi hak masyarakat, wilayah desa sangat penting diketahui dan dipertahankan untuk mencegah konflik yang timbul baik dari dalam wilayah desa sendiri maupun dari luar wilayah desa. Pentingnya mengetahui wilayah desa juga berperanan bagi masyarakat untuk mengatur wilayah desanya terhadap pemanfaatan lahan. Para kepala desa maupun kepala adat juga berperan penting untuk mengatur warganya bila sudah memiliki wilayah desa yang jelas. Bagi kepentingan pemerintahan hal itu dapat mempermudah dalam pengaturan tata ruang wilayah terhadap penggunaan lahan dalam berbagai bidang. Di bawah ini diuraikan masalah-masalah yang dapat diatasi dengan adanya wilayah desa.

\section{Mencegah Konflik dari dalam Wilayah Desa dan Wilayah Adat}

Konflik di desa dapat timbul dari dalam, yaitu dari warga masyarakat sendiri terutama sebagai akibat pemanfaatan sumberdaya di dalam wilayah desa sendiri. Pemanfaatan sumberdaya hutan telah diatur dalam hukum adat, khususnya Adat Besar Hulu Bahau, Pasal XI, dan menunjuk pada keputusan kepala-kepala desa Hulu Bahau pada surat nomor 01/K.A.B./II/1994 tertanggal 3 Februari 1994 di Apau Ping. Pengambilan hasil hutan antar desa tidak harus persis dalam garis perbatasan desa. Khusus untuk sembilan desa di Hulu Bahau, boleh melewati asalkan ada ijin dari kepala-kepala desa bersangkutan dan berdasarkan kekeluargaan.

Pemakaian lahan dalam wilayah desa khususnya batas ladang, diatur dalam Pasal X, Ayat a. yang menyatakan: terjadi pelanggaran atas batas ladang di antara masyarakat itu sendiri yang tadinya diberi tanda dan disepakati oleh kedua belah pihak yang berbatasan ladang pada waktu menebas hingga pada waktu menebang. Ternyata pada 
waktu menugal (menanam padi) karena sudah bersih satu pihak menggeser atau merubah tanda tersebut, perbuatan ini dikenai denda satu buah parang biasa, dan diserahkan kepada yang menuntut. Ayat b. menyatakan: terjadi perebutan atau keributan mengenai batas perladangan antara desa langsung ditangani oleh Kepala Adat Besar Hulu Bahau dengan rasa kekeluargaan atau pertimbanganpertimbangan dan kebijaksanaan bersama dari kedua hakim adat yang bersangkutan, sesuai dengan hasil musyawarah para kades Hulu Bahau di Apau Ping (tahun 1994).

\section{Mencegah Konflik dari Luar}

Ancaman terhadap perusakan hutan secara besar-besaran yang berasal dari luar wilayah desa, misalnya HPH dengan menggunakan peralatan modern dapat merusakkan ribuan hektar sumberdaya hutan yang bermanfaat bagi masyarakat dan mengganggu sungai dalam waktu singkat. Konversi hutan untuk berbagai kepentingan dengan membuka areal hutan yang luas juga dapat terjadi dalam waktu yang tidak terlalu lama. Para pencari gaharu dari luar daerah yang terdiri dari rombongan besar dapat merusakkan sistem pengelolaan hutan yang diterapkan oleh masyarakat, sehingga akhirnya dapat mengancam kelestarian pemanfaatan sumberdaya gaharu dan sumberdaya lain yang turut diambil. Sistem pemanfaatan pencari gaharu dari luar yang tanpa memperhatikan pelestarian, di mana mereka langsung menebang pohon gaharu walaupun tidak ada isinya dapat mengancam sumber pendapatan masyarakat setempat. Demikian pula dengan binatang buruan yang ditangkap menjadi semakin banyak jumlahnya sehingga pada akhirnya menjadi pesaing yang dapat mengurangi hasil tangkapan penduduk setempat. Akhirnya jika tidak ada pembatasan, pencari gaharu dari luar yang masuk dalam jumlah besar dapat menimbulkan konflik dengan masyarakat.

Dalam aturan adat yang telah ditetapkan berdasarkan Keputusan Musyawarah Kepala-Kepala Desa dan Kepala Adat Hulu Bahau pada waktu Pesta Panen Gabungan di Desa Long Tebulo tahun 
1996, telah diatur dalam Pasal XXV (dapat dilihat pada bagian Hukum Adat terhadap Hutan dalam tulisan ini) yang intinya membatasi pengusaha untuk memungut hasil hutan seperti: gaharu, rotan, kayu manis, dan damar. Pengusaha-pengusaha hasil hutan dari luar daerah tidak diperkenankan memungut hasil hutan secara langsung, tetapi boleh membeli dari masyarakat dengan ijin dari Bupati. Pengusaha hasil hutan asal putra daerah yang sudah pindah ke tempat lain, diperkenankan dalam waktu terbatas untuk satu sampai tiga orang dan bergabung dengan masyarakat setempat. Pengusaha hasil hutan asal putera daerah yang anggotanya lebih dari tiga orang tidak diberi ijin masuk ke hutan. Pengusaha hasil hutan yang masuk tanpa ijin, didenda Rp. 500.000 per orang, uangnya masuk kas adat. Pengusaha hasil hutan yang melalui ijin hanya diperkenankan masuk ke hutan setelah menyerahkan sumbangan ke kas adat sebesar Rp. 500.000 dan maksimum lima orang dalam satu rombongan dengan batas waktu yang dapat dirundingkan dengan kepala desanya. Dengan adanya pengaturan hutan berdasarkan hukum adat secara lokal dan tana' ulen maka konflik dapat dicegah.

\section{SANKSI-SANKSI TERHADAP PELANGGARAN HUKUM ADAT}

Bagi pelanggaran yang dilakukan terhadap peraturan yang dibuat di atas, dikenakan sanksi-sanksi berupa denda dengan barang atau setara nilai uang yang telah ditetapkan. Adapun peraturan yang belum tercantum atau adanya kemungkinan muncul permasalahan baru yang belum termuat dalam hukum adat tersebut akan dilakukan tindakan berdasarkan hasil musyawarah adat secara kekeluargaan.

Denda pelanggaran yang ditetapkan dan penyetaraan nilai uang berdasarkan Keputusan Musyawarah Besar Kepala-Kepala Desa dan Kepala Adat Hulu Bahau di Long Tebulo pada tahun 1996, sebagai berikut: 
a. Tempayan busi pu'un (pelayung wing)

Rp. 500.000

b. Tempayan busi kabuk

Rp. 400.000

c. Tempayan busi abai

Rp. 300.000

d. Tempayan busi wai

Rp. 250.000

e. Tempayan $\boldsymbol{b e} \mathbf{l a}$ '

Rp. 200.000

f. Anggung pu'un

Rp. 500.000

g. Anggung jangin

Rp. 100.000

h. Anggung batu

Rp. 50.000

i. Anggung jilen

Rp. 200.000

j. Parang berukir dan rambut

Rp. 200.000

k. Parang biasa lengkap

Rp. 30.000

Sumber: Keputusan Musyawarah Kepala-Kepala Desa dan Kepala Adat Hulu Bahau di Long Tebulo Tahun 1996.

\section{E. PENGAKUAN HUTAN ADAT BERDASARKAN UNDANG-UNDANG NEGARA}

Pada bulan September 1999 telah berhasil dibuat Rancangan UndangUndang Republik Indonesia tentang Kehutanan, di mana dalam Rancangan Undang-Undang ini telah disebutkan bahwa pemerintah mengakui hutan adat dan memperhatikan hak masyarakat hukum adat. Pasal 1 ayat (6) menyatakan sebagai berikut: "Hutan adat adalah hutan negara yang berada dalam wilayah masyarakat hukum adat". Selanjutnya dijelaskan pada Pasal 4 ayat (3) yang bunyinya sebagai berikut: "Penguasaan hutan oleh negara tetap memperhatikan hak masyarakat hukum adat, sepanjang kenyataannya masih ada dan diakui keberadaannya, serta tidak bertentangan dengan kepentingan nasional".

Pasal 5 ayat (2): "Hutan negara sebagaimana dimaksud pada ayat (1) huruf a, dapat berupa hutan adat". Ayat (3): "Pemerintah menetapkan status hutan sebagaimana dimaksud pada ayat (1) dan ayat (2); dan hutan adat ditetapkan sepanjang menurut kenyataannya masyarakat yang bersangkutan masih ada dan diakui keberadaannya". Ayat (4): "Apabila dalam perkembangannya masyarakat hukum adat yang bersangkutan tidak ada lagi, maka hak pengelolaan hutan adat kembali kepada pemerintah". 
Pengelolaan hutan berdasarkan hukum adat dijelaskan pada Pasal 67 yang bunyinya sebagai berikut: ayat (1) "Masyarakat hukum adat sepanjang menurut kenyataannya masih ada dan diakui keberadaannya berhak: a. melakukan pemungutan hasil hutan untuk pemenuhan kebutuhan hidup sehari-hari masyarakat adat yang bersangkutan; b. melakukan kegiatan pengelolaan hutan berdasarkan hukum adatyang berlaku dan tidak bertentangan dengan undang-undang; dan c. mendapatkan pemberdayaan dalam rangka meningkatkan kesejahteraan. Ayat (2) "Pengukuhan keberadaan dan hapusnya masyarakat bukum adat sebagaimana dimaksud pada ayat (1) ditetapkan dengan Peraturan Daerah". Ayat (3) Ketentuan lebih lanjut sebagaimana dimaksud pada ayat (1) dan ayat (2) diatur dengan Peraturan Pemerintah.

Pasal 68 ayat (3) Masyarakat di dalam dan di sekitar hutan berhak memperoleh kompensasi karena hilangnya akses dengan hutan sekitarnya sebagai lapangan kerja untuk memenuhi kebutuhan hidupnya akibatpenetapan kawasan hutan, sesuai dengan peraturan perundang-undangan yang berlaku. Ayat (4) Setiap orang berhak memperoleh kompensasi karena hilangnya hak atas tanah miliknya sebagai akibat dari adanya penetapan kawasan hutan sesuai dengan ketentuan peraturan perundang-undangan yang berlaku.

Selain itu pemerintah juga memberikan hak terhadap hutan untuk tujuan khusus. Pasal 8 ayat 1 bunyinya: "Pemerintah dapat menetapkan kawasan butan tertentu untuk tujuan khusus", yaitu untuk kepentingan umum antara lain disebutkan pada ayat 2 huruf c. religi dan budaya". Kemudian dijelaskan dalam Pasal 34 yang bunyinya: "Pengelolaan kawasan hutan untuk tujuan khusus sebagaimana dimaksud dalam Pasal 8 dapat kepada: a. masyarakat hukum adat dan d. Lembaga sosial dan keagamaan.

Pasal 71 ayat (1) "Masyarakat berhak mengajukan gugatan perwakilan ke pengadilan dan atau melaporkan ke penegak hukum terhadap kerusakan hutan yang merugikan kehidupan masyarakat". Ayat (2) "Hak mengajukan gugatan sebagaimana dimaksud pada ayat (1) terbatas pada tuntutan terhadap pengelolaan hutan yang tidak sesuai dengan peraturan perundang-undangan yang berlaku".

Pasal 72 "Jika diketahui bahwa masyarakat menderita akibat pencemaran dan atau kerusakan hutan sedemikian rupa sehingga mempengaruhi kehidupan masyarakat, maka instansi pemerintah atau instansi pemerintah 
daerah yang bertanggung jawab di bidang kehutanan dapat bertindak untuk kepentingan masyarakat".

Harus dijelaskan bawa hukum ini belum diterapkan secara luas di Indonesia, termasuk di hulu Sungai Bahau dan tidak ada kaitan yang langsung dengan konsep tana' ulen. Sebagian masyarakat di Sungai Bahau tahu tanahnya adalah tanah milik negara (menurut pemerintah) karena sudah status taman nasional, tetapi tidak semuanya setuju dengan status ini. Masih belum jelas apakah mereka mau terapkan hukum "hutan adat" yang baru dengan arti bahwa tana' ulen sebetulnya tanah negara, atau apakah mereka ingin menuntut status lain. Di samping ini, belum jelas juga apakah pemerintah Kabupaten Malinau ingin terapkan hukum tersebut di TN Kayan Mentarang. 


\section{Bab 5 \\ Kesimpulan dan \\ Rekomendasi Kebijakan}

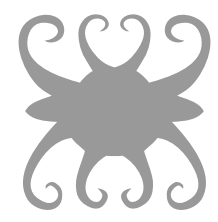

Menunjuk pada uraian di atas bahwa begitu besar ketergantungan masyarakat Dayak di sekitar TN Kayan Mentarang terhadap hutan: (1) hutan merupakan sumber kehidupan sebagai mata pencaharian utama, (2) keterkaitan budaya masyarakat Dayak terhadap hutan sangat tinggi, (3) timbal balik antara budaya dan ketergantungan ekonomi, dan secara ekologi berupa sistem unik, (4) masyarakat Dayak di sekitar TN Kayan Mentarang telah memiliki hukum adat secara lokal, (5) menimbang adanya pengakuan hutan adat berdasarkan undang-undang negara, (6) keterkaitan antara pelestarian (konservasi) hutan dengan kesejahteraan masyarakat Dayak di sekitar TN Kayan Mentarang, dan (7) mencegah konflik mengenai penggunaan lahan baik dari dalam maupun dari luar, maka dengan itu kami merekomendasikan agar pengelolaan hutan secara lokal oleh masyarakat asli setempat diberi status hukum yang sah berdasarkan undang-undang negara, agar dapat mencegah terjadinya konflik sehingga masyarakat asli mendapat hak untuk mengatur wilayahnya sendiri terhadap sumber pendapatan dan perekonomian yang dapat menjamin kelangsungan hidup mereka dan kelangsungan pembangunan. Sampai sekarang, dengan banyak ketidakpastian mengenai kebijakan kehutanan dengan keadaan Otonomi Daerah, masyarakat di Hulu Bahau masih belum punya hak atas wilayahnya secara sah. 
Ancaman terhadap pemanfaatan lahan hutan memerlukan adanya hukum negara yang kuat atas batas wilayah hutan dan hak atas pemanfaatan hutan yang adil dengan masyarakat. Hukum adat diakui dan bisa dipadukan dengan hukum negara untuk mencapai tujuan kesejahteraan, mata pencaharian, dan budaya. Dengan bertambahnya kebutuhan lahan, penting sekali batas wilayah desa mendapat perhatian untuk disahkan secara hukum dan administrasi pemerintahan untuk mencegah konflik antar warga desa satu dengan lainnya.

Batas wilayah desa penting juga mendapat pengesahan status hukum untuk mencegah timbulnya konflik dari luar terhadap kepentingan pemanfaatan lahan, misalnya para investor yang ingin menanamkan modalnya untuk mengambil lahan yang luas atau pencari hasil hutan seperti gaharu yang tidak memikirkan kelestarian hasil.

Pengaturan tata ruang untuk pembangunan daerah terhadap berbagai kepentingan dan rencana pembangunan juga perlu mengetahui batas-batas yang jelas misalnya terhadap wilayah desa, agar tidak terjadi perencanaan yang tumpang tindih dalam satu lokasi untuk berbagai kepentingan yang dapat menimbulkan konflik. Oleh sebab itu penetapan dan pengesahan batas-batas wilayah desa berdasarkan undang-undang negara sangat diperlukan bagi kepentingan berbagai pihak, terutama bagi desa itu sendiri, pemerintah daerah, dan negara.

Oleh sebab itu jika tidak ada pembatasan luas lahan, maka pembangunan dengan menggunakan peralatan modern akan selalu kekurangan lahan. Sehingga apabila tidak ada batas dan hak yang jelas dan sah untuk penggunaan lahan pada berbagai kepentingan termasuk hak-hak untuk masyarakat asli maka akan terjadi konflik. Konflik bisa terjadi antara masyarakat dengan pemakai lahan di sekitarnya (HPH, pertambangan, transmigrasi), akibat konflik ini semua pihak akan rugi dan tidak ada yang diuntungkan. Yang untung adalah apabila semua pihak telah mendapat hak dengan batas-batas yang jelas dan mendapatkan keputusan berdasarkan undang-undang negara yang ditetapkan oleh pemerintah. Sehingga apabila terjadi 
konflik masyarakat dapat mempertahankan hak berdasarkan "SK" masing-masing dan dapat ditempuh melalui jalur hukum tanpa kekerasan. 


\section{Catatan Kaki}

${ }^{1}$ Perbedaan tulisan istilah Kenyah Leppo' Ké di sini dengan yang ada di Puri (2001) mencerminkan perbedaan pendapat sesuai dengan pengalaman penulis utama sebagai orang Kenyah asli.

${ }^{2}$ Nama lokal ditulis dengan huruf tebal dan miring.

${ }^{3}$ Kebanyakan jamur (kulat) mengandung racun yang mematikan. Kulat lung dapat membuat mabuk jika dimakan berlebihan.

${ }^{4}$ Beberapa jenis payang digunakan untuk membuat terasi melalui proses yang dibuat secara peragian.

${ }^{5}$ Ada cerita dari mulut ke mulut tentang kisah asal-usul pemanfaatan burung krukep sebagai obat. Konon dulu ada orang Kenyah patah tulang pada kakinya. Kemudian dia pergi mencari obat sampai dia menemukan anak burung krukep di sarangnya. Anak burung ini kemudian dipatahkan kakinya lalu diintip sampai induknya pulang. Setelah induknya datang dan dilihat kaki anaknya patah maka induk burung ini pergi mencarikan obat. Saat induknya pulang membawa obat, maka obat tersebut direbut oleh orang yang mengintip tadi. Obat inilah dipakai untuk mengobati orang yang patah tulang. Kemudian obat tersebut diperhatikan baik-baik, berasal dari jenis apa. Lalu diingat dan dipelajari. Namun sebagian besar orang sekarang menganggap bahwa burung tersebutlah sebagai obat, dan banyak orang sudah memakainya sampai sekarang. 
${ }^{6}$ Arak adalah minuman tradisional khas Dayak Kenyah Hulu Sungai Bahau yang dibuat melalui proses peragian singkong kemudian disuling. Arak (atau chiu) ini diminum secara teratur untuk memulihkan tenaga dan menyegarkan badan.

${ }^{7}$ Para pencari gaharu secara tradisional melukai batang kayu gaharu dengan menggunakan kampak atau parang. Apabila tidak ada isi yaitu endapan ekstraktif yang berwarna gelap, maka kayu tersebut dibiarkan hidup dan ditinggalkan. Adanya luka ini merangsang pohon gaharu memproduksi resinnya. Tahun berikutnya mereka datang lagi memeriksa bagian kayu yang luka tersebut, umumnya sudah ada endapan ekstraktif di sekitar bagian kayu yang luka tersebut.

${ }^{8}$ Harga rotan jatuh karena tidak ada pembeli, akibat adanya larangan ekspor rotan mentah. Apabila pemerintah membuka ijin ekspor, kemungkinan harga rotan akan membaik.

${ }^{9}$ Satu batang rotan sega (Calamus caesius) dibelah menjadi empat kemudian diambil kulitnya diraut untuk menjadi bahan anyaman. Satu blanyat ukuran sedang yaitu tinggi $32 \mathrm{~cm}$ diameter $15 \mathrm{~cm}$ membutuhkan 180 lembar rautan rotan yang berasal dari 45 sampai 50 batang rotan sepanjang 5 meter.

${ }^{10}$ Merayakan kepala yang dipotong dan berdoa sesudah memanen hasil hutan, mendoakan hasil panen, serta membuang sial dan mencuci kampung (lihat halaman 67).

${ }^{11}$ Hasil penelitian Colfer 1979/80, studi kasus suku Dayak Kenyah Uma' Jalan di Kalimantan Timur, dalam rangka proyek penelitian MAB (Man and Biosphere) mengenai Interaction between People and Forest in East Kalimantan, dalam Colfer 1997.

${ }^{12}$ Sungai Benuang tempat pembuangan air yang berasal dari lokasi tambang batu bara. Air yang menggenang di dalam tambang dipompa ke atas dengan mesin kemudian dialirkan ke Sungai Benuang.

${ }^{13}$ Apui Njau adalah Kepala Adat Besar Hulu Bahau tahun 1925 sampai 1967. Lahir tahun 1901, kemudian dipenjarakan oleh Belanda di Batavia (sekarang Jakarta) pada tahun 1920 sampai 1925 karena 
membunuh orang Bulungan. Selama dalam penjara beliau belajar menulis dan bersawah. Setelah kembali tahun 1925 beliau mengajarkan orang membuat sawah di hulu Sungai Bahau. Apui Njau wafat tahun 1967 di Long Alango.

14 Sayangnya, dalam rangka proyek ini tidak ada kesempatan mengumpulkan data mengenai kemarau panjang selain yang ini.

${ }^{15}$ Sifat genetik yang dimaksudkan di sini adalah sifat-sifat tumbuhan tersebut, baik yang nampak maupun yang tidak nampak. Sifat yang nampak misalnya: warna, ukuran buah, ukuran daun, panjang, pendek, dan sebagainya. Sifat yang tidak nampak misalnya: rasa manis, asam, ketahanan terhadap penyakit, dan lain-lain.

${ }^{16}$ Orang Dayak melindungi hutan bukan berarti hutan tidak boleh dimanfaatkan sama sekali, melainkan justru untuk mengambil manfaatnya yaitu binatang buruan.

17 Ba'bui satung arti katanya sebagai berikut : $\boldsymbol{b} \boldsymbol{a}^{\prime} \boldsymbol{b} u \boldsymbol{i}=\mathrm{babi}$, satung=berenang, nyatung=sedang berenang, matung=hanyut.

${ }^{18}$ Selarang artinya ikan patin, karena ikan patin sangat suka makan buah ini.

${ }^{19}$ Contoh nama-nama di sini diambil dari berbagai bahasa sub suku Dayak Kenyah.

${ }^{20}$ Ada kaitan antara hukum adat dengan hukum negara, contoh: dalam hukum adat yang ditetapkan tanggal 20 Juni 1996, hasil Pesta Panen Gabungan di Long Tebulo, pada Pasal V ayat d. menyebutkan bahwa jika terjadi perkelahian yang menyebabkan korban jiwa diserahkan kepada polisi. Selain itu juga terdapat kaitan hukum adat dengan pemerintah pada Pasal XXV ayat a. (dapat dilihat pada Bab IV B. Hukum Adat Terhadap Hutan).

${ }^{21}$ Pasal X Ayat a. bunyinya: Terjadi pelanggaran atas watas ladang di antara masyarakat desa itu sendiri yang tadinya diberi tanda/disepakati oleh kedua belah pihak yang berbatasan ladang pada waktu menebas hingga menebang ternyata pada waktu menugal (karena sudah bersih) satu pihak menggeser/merubah tanda tersebut, dikenakan denda: 1 
buah parang biasa diserahkan kepada yang menuntut. Ayat b, bunyinya: Terjadi perebutan/keributan mengenai watas perladangan antara desa langsung ditangani oleh Kepala Adat Besar Hulu Bahau dengan rasa kekeluargaan/pertimbangan-pertimbangan kebijaksanaan bersama dari kedua hakim-hakim adat yang bersangkutan, sesuai hasil musyawarah para Kades-kades Hulu Bahau di Apau Ping.

${ }^{22}$ Pasal XI bunyinya : Hasil hutan, daerah perladangan, persawahan, kayu yang dapat dimanfaatkan untuk bahan bangunan, perahu dan lain-lain tidak harus pada titik garis watas desa yang telah ditetapkan untuk memperoleh sesuatu seperti tersebut di atas tetapi hendaklah kesemuanya melalui ijin dari desa yang bersangkutan dengan rasa kekeluargaan (boleh lewat) khusus 9 desa di Hulu Bahau, periksa keputusan Kepala-kepala Desa Hulu Bahau pada surat No. 01/ K.A.B./II/1996, tertanggal 3 Februari 1994, di Apau Ping.

${ }^{23}$ Tana' ulen juga disebut polong ulen yang artinya hutan larangan. 


\section{Pustaka}

Anau, Njau. 1999. Sejarah suku Kenyah Leppo' Ke dan Nyibun di Kecamatan Long Pujungan. In: Eghenter, C. adn Sellato, B. (eds.) Kebudayaan dan pelestarian alam: penelitian interdisipliner di pedalaman Kalimantan. PHPA/The Ford Foundation/WWF, Jakarta, Indonesia.

Apui, Anye 1996. Keputusan musyawarah Kepala-Kepala Desa/ Kepala Adat Hulu Bahau di Long Tebulo tahun 1996. 7 halaman.

Colfer, C. et al. 1997. Peladang berpindah di Indonesia: perusak atau pengelola hutan? Produksi padi dan pemanfatan hutan Uma' Jalan di Kalimantan Timur.

Eghenter, C. and Sellato, B. (eds.) 1999. Kebudayaan dan pelestarian alam: penelitian interdisipliner di pedalaman Kalimantan. PHPA/ The Ford Foundation/WWF, Jakarta, Indonesia.

Hartadi, I. 1996. Daftar tumbuhan gaharu yang termasuk dalam CITES dan masuk ke dalam Apendix II. Database WWF/IP Jakarta.

Momberg, F., Puri, R.K., and Jessup, T. 2000 Exploitation of gaharu and forest conservation efforts in the Kayan Mentarang National Park, East Kalimantan, Indonesia. In: Zerner, C. (ed.) People, plants and justice. Columbia University Press, New York.

Puri, R.K., 2001. The Bulungan ethnobiology handbook. CIFOR, Bogor, Indonesia. 
Puri, R.K., 1997. Hunting knowledge of the Punan Benalui of East Kalimantan, Indonesia. Unpublished Ph.D. Dissertation. University of Hawaii, Department of Anthropology.

Soedjito, H. dan Kartawinata, K., 1987. Keberadaan masyarakat dan budaya Dayak dalam kaitannya dengan kelestarian hutan hujan tropik di Kalimantan. Makalah untuk diskusi "Kearifan Tradisional Masyarakat Dayak dalam Berladang dan Pengendalian Kebakaran Hutan" dalam rangka Pekan Budaya: Masyarakat Dayak dan Hutan Kalimantan (Kerudung Asap di Kalimantan). Taman Ismail Marzuki, Jakarta tanggal 30 Nopember dan 1 Desember 1987.

Soedjito, H. 1991. Environmental knowledge and biological diversity in East Kalimantan, "Forest, Field, and Sea: Folklife in Indonesia". 65-68.

Uluk, A. dan Wollenberg, E. 1998. Pemanfaatan hutan dan ekonomi rumah tangga di kawasan Taman Nasional Kayan Mentarang (versi Bahasa Kenyah. World Wide Fund for Nature and CIFOR report. Wollenberg, E. 2001. Incentives for collecting gaharu (fungal-infected Wood of Aquilaria spp.; Thymelaeaceae) in East Kalimantan. Economic Botany 55(3): 98-110.

Wollenberg, E., Nawir, A.S., and Uluk, A. 2000. Income is not enough: the effect of economic incentives on forest conservation. CIFOR Working Paper No. 21. CIFOR, Bogor, Indonesia.

Wollenberg, E. dan Uluk, A. 1998. Pemanfaatan Hutan dan Ekonomi Rumah Tangga di Kawasan Taman Nasional Kayan Mentarang (versi Bahasa Indonesia), World Wide Fund for Nature and CIFOR report. 


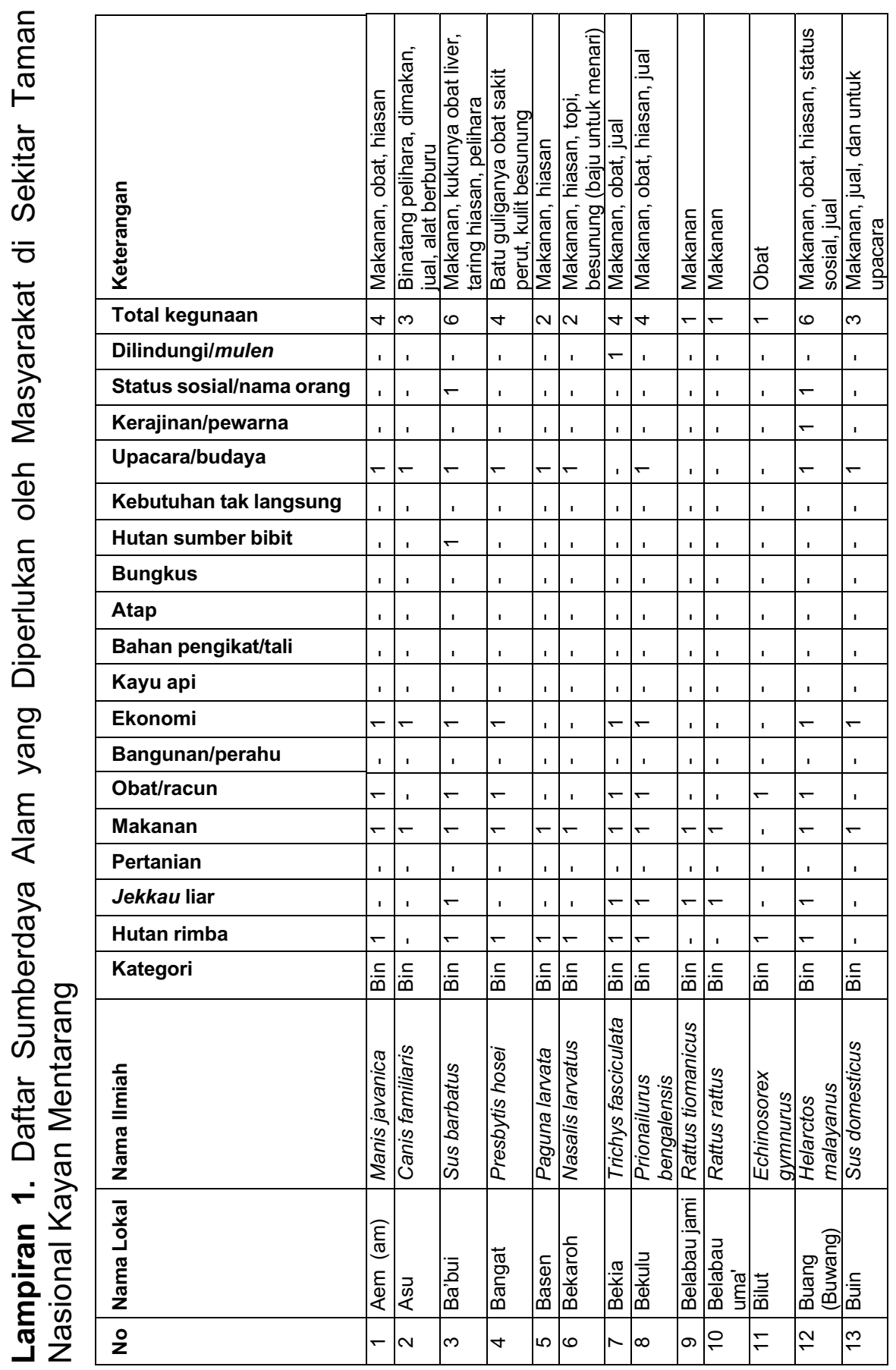




\begin{tabular}{|c|c|c|c|c|c|c|c|c|c|c|c|c|c|c|}
\hline 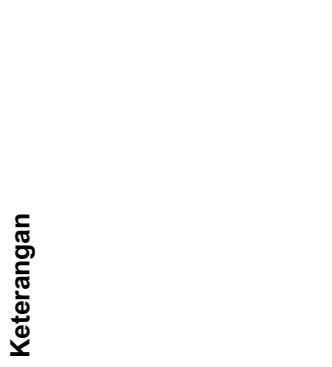 & 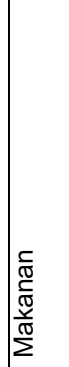 & 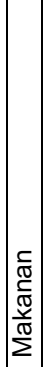 & 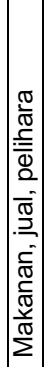 & 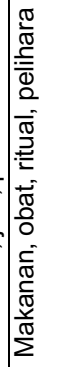 & 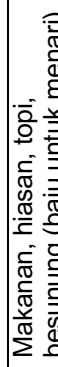 & 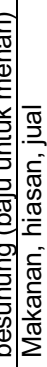 & 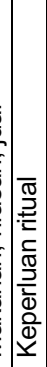 & 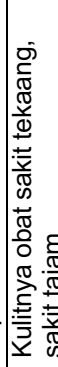 & 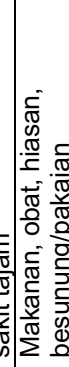 & 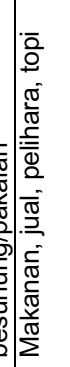 & 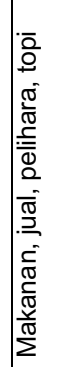 & 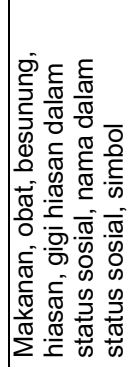 & 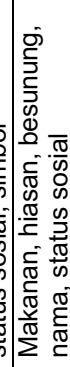 & 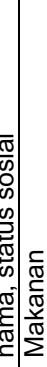 \\
\hline Total kegunaan & 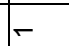 & - & + & $m$ & N & m & - & N & $m$ & $m$ & $m$ & 0 & ما & N \\
\hline Dilindungi/mulen & . &. &. & . & . & , &. & . & , & . & . & - & . & . \\
\hline Status sosial/nama orang & , &. &. & . & . & , &. & . & . & I & , & - & - & . \\
\hline Kerajinan/pewarna & , &. &. & . & , & , &. & . & , & , & , & - & - & , \\
\hline Upacara/budaya & , & . &. & - & - & - & - & . & - & - & - & - & - & - \\
\hline Kebutuhan tak langsung & , &. & - & . & . & . & 1 & . & , & , & , & , & . & , \\
\hline Hutan sumber bibit & . &. & - &. & . & . &. & . & , & . & , & , & , & . \\
\hline Bungkus & , &. &. & . & , & , &. & . & , & 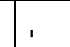 & . & , & , & , \\
\hline Atap & , &. &. & . & . & . & 1 & . & . & ' & ' & I & . & , \\
\hline Bahan pengikat/tali & . & . &. & 1 & 1 & , & 1 & 1 & . & 1 & 1 & 1 & , & . \\
\hline Kayu api & , &. & . & . & . & . & . & I & . & , & , & , & . & . \\
\hline Ekonomi & . &. & - & . & . & - &. & . & , & - & - & , & - & , \\
\hline Bangunan/perahu & , &. &. & . & , & , &. & . & . & , & . & , & , & . \\
\hline Obat/racun & , &. &. & - & . & . &. & - & - & , & , & - & . & , \\
\hline Makanan & - & - & - & - & - & - &. & - & - & - & - & - & - & - \\
\hline Pertanian & , & .1 &. & . & . & . &. & . & , & , & , & I & . & , \\
\hline Jekkau liar & . &. & - & 1 &. & - &. & - &. & . & . & , & . & - \\
\hline Hutan rimba & , & - & - & - & - & - & - & . & - & - & - & - & - & - \\
\hline Kategori & $\therefore$ & $\because \frac{\bar{\omega}}{4}$ & $\because \frac{\bar{\omega}}{4}$ & $\because \frac{.}{0}$ & 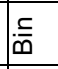 & $\frac{.}{\bar{\omega}}$ &.$\check{\bar{\omega}}$ & $\cong \overline{0}$ & $\cong$ & $\therefore \overline{\bar{\omega}}$ & $\therefore \overline{\overline{0}}$ & $\therefore$ & $\cong$ & $\subseteq \bar{\omega}$ \\
\hline 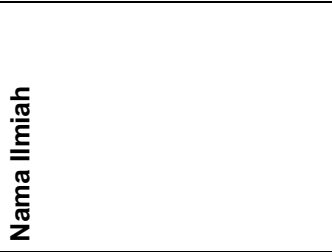 & 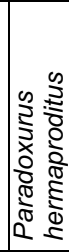 & 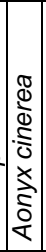 & 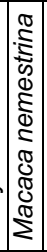 & 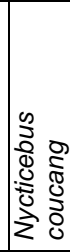 & 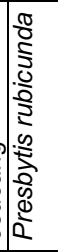 & 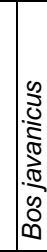 & 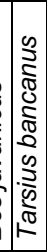 & 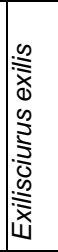 & 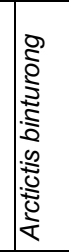 & 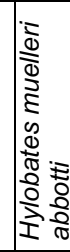 & 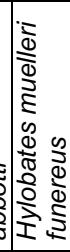 & $\frac{1}{0}$ & 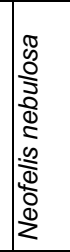 & 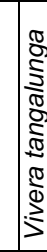 \\
\hline 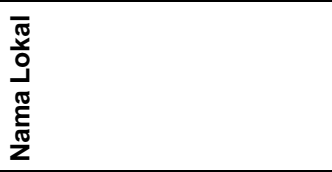 & 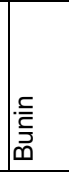 & 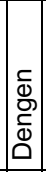 & $\frac{r}{3}$ & 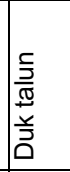 & 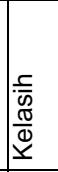 & 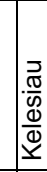 & 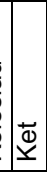 & $\begin{array}{l}\frac{0}{2} \\
\frac{1}{0} \\
\frac{0}{2}\end{array}$ & 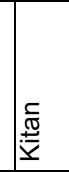 & $\begin{array}{l}\bar{\Sigma} \\
\frac{\bar{\nu}}{\sigma} \\
\frac{\pi}{\Sigma}\end{array}$ & 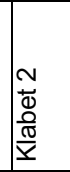 & $\begin{array}{l}\underline{0} \\
\frac{1}{2} \\
\frac{\bar{a}}{2} \\
\frac{1}{2} \\
\underline{2}\end{array}$ & 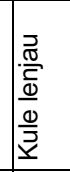 & 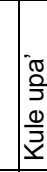 \\
\hline 우 & $\nsubseteq$ & 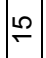 & 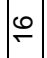 & $\vDash$ & $\stackrel{\infty}{\circ}$ & 음 & $\stackrel{\sim}{2}$ & $\bar{N}$ & $\approx$ & $\stackrel{N}{N}$ & $\stackrel{\text { N }}{4}$ & $\stackrel{\sim}{\sim}$ & $\stackrel{N}{\sim}$ & $\hat{N}$ \\
\hline
\end{tabular}




\begin{tabular}{|c|c|c|c|c|c|c|c|c|c|c|c|c|}
\hline 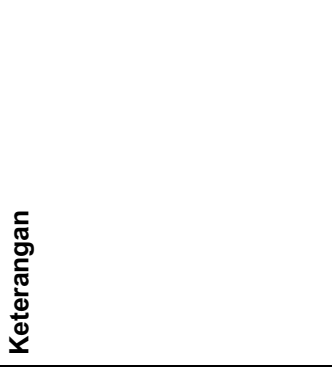 & 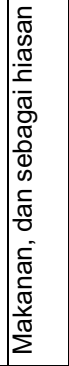 & 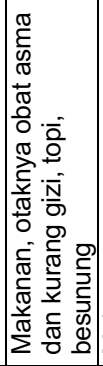 & 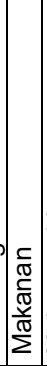 & 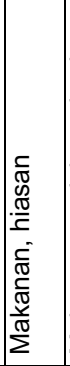 & 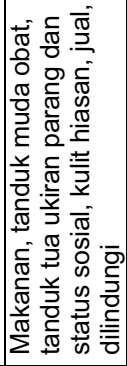 & 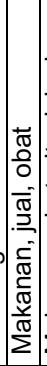 & 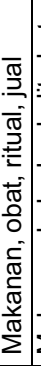 & 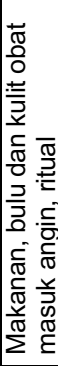 & 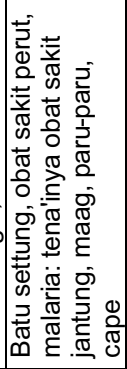 & 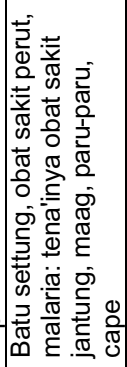 & 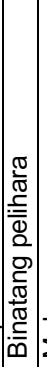 & 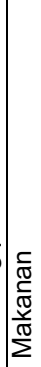 \\
\hline Total kegunaan & N & + & - & N & $\infty$ & $n$. & $\nabla$ & $m$ & $\nabla$ & $\checkmark$ & - & - \\
\hline Dilindungi/mulen & ' & . & $\cdot$ &. & - & $\cdot$ & I & 1 & 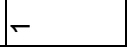 & $\leftarrow$ &. & . \\
\hline Status sosial/nama orang & I & , &. & . & - &. & . & 1 & , & , & . & . \\
\hline Kerajinan/pewarna & - & - &. & . & 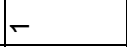 &. & 1 &. & . & . &. &. \\
\hline Upacara/budaya & ' & 1 & $\cdot$ & - & - & . & - & - & ' & ' & - & 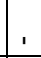 \\
\hline Kebutuhan tak langsung & . & - &. & 1 & 1 &. & . & 1 & ' & 1 & 1 & . \\
\hline Hutan sumber bibit & 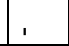 & , &. & . & 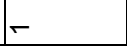 &. & , & . & . & 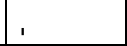 & . &. \\
\hline Bungkus & 1 & . & 1 &. & 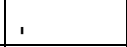 &. & 1 & . & 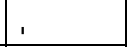 & 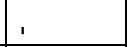 & . & . \\
\hline Atap & ' & 1 &. & . & 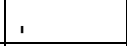 &. & 1 & 1 & 1 & ' &. & . \\
\hline Bahan pengikat/tali & ' & . &. & . & ' & . & I & 1 & . & . & . &. \\
\hline Kayu api & ' & , & ' & 1 & ' & . & ' & . & ' & ' & . & . \\
\hline Ekonomi & . & . & 1 &. & - & - & - &. & - & - &. &. \\
\hline Bangunan/perahu & , & , &. &. & , &. & , &. & ' & , &. & . \\
\hline Obat/racun & 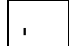 & - &. & . & - & - & - & - & - & - &. & . \\
\hline Makanan & - & - & - & - & - & - & - & - & - & - & & - \\
\hline Pertanian & ' & . & $\cdot$ & . & 1 & . & $\cdot$ & 1 & ' & ' & . & $\cdot$ \\
\hline Jekkau liar & , & - & - & 1 & - & . & - & . & - & $\leftarrow$ & & - \\
\hline Hutan rimba & - & - & - & - & - & - & - & - & - & - &. & . \\
\hline Kategori &.$\overline{\mathbf{m}}$ &.$\check{0}$ & $\because \frac{\bar{\omega}}{0}$ &.$\overline{0}$ &.$\check{\bar{\omega}}$ & $\therefore$ 音. & 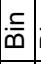 & $\because \overline{0}$ & 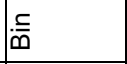 & 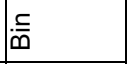 & & $\stackrel{\overline{0}}{0}$ \\
\hline 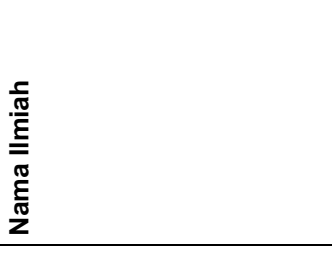 & 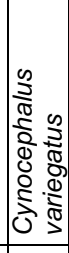 & 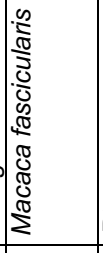 & 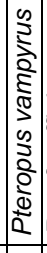 & 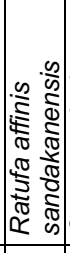 & 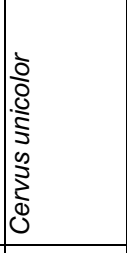 & 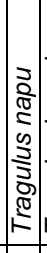 & 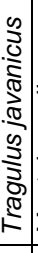 & 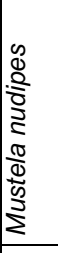 & 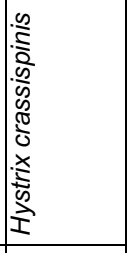 & 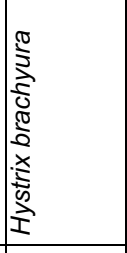 & 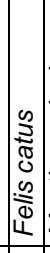 & 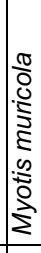 \\
\hline 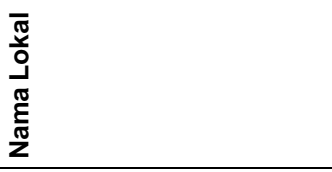 & 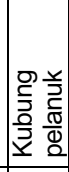 & $\frac{\pi}{2}$ & 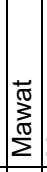 & 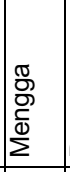 & $\begin{array}{l}\vec{\infty} \\
\substack{\bar{d} \\
\square} \\
\end{array}$ & 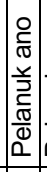 & 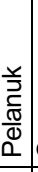 & 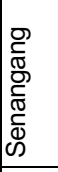 & 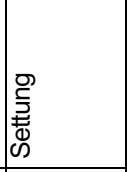 & 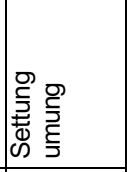 & 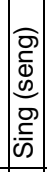 & $\frac{\pi}{\square}$ \\
\hline 운 & $\stackrel{\infty}{N}$ & N & ০্লি & $\bar{m}$ & $\widetilde{m}$ & $m$ & फे & ભ & 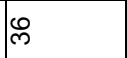 & $\hat{m}$ & & శ্ল \\
\hline
\end{tabular}




\begin{tabular}{|c|c|c|c|c|c|c|c|c|c|c|c|}
\hline 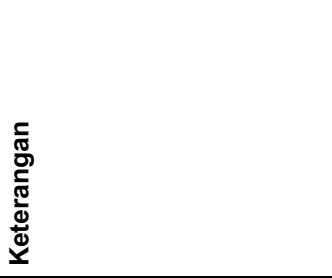 & 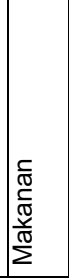 & 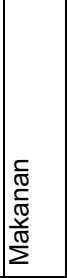 & 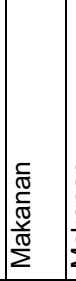 & 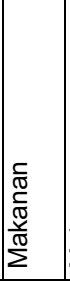 & 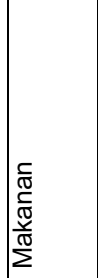 & 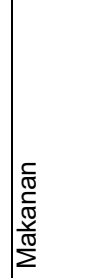 & 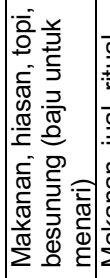 & 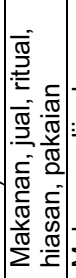 & 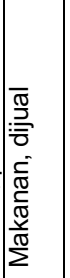 & & 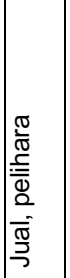 \\
\hline Total kegunaan & - & - & - & - & N & N & N & 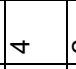 & N & $\stackrel{m}{m}$ & N \\
\hline Dilindungi/mulen & , & . & . & 1 & . & 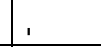 & . & . & 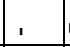 & 10 & . \\
\hline Status sosial/nama orang & . & , & 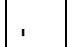 & . & ' & . & , & , & 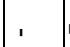 & 10 & . \\
\hline Kerajinan/pewarna & 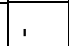 & , & . & , & , & , & , &. & , & 0 & . \\
\hline Upacara/budaya & ' & , & ' & 1 & - & - & - & - & $\cdot$ & $\stackrel{\infty}{\sim}$ & . \\
\hline Kebutuhan tak langsung & , & , & , & , & I & , & , & , & 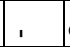 & $\sim$ & . \\
\hline Hutan sumber bibit & , & , & , & , & , & , & , & , & , & $m$ & - \\
\hline Bungkus & , & , & , & . & 1 & ' & . & , & , & 0 & . \\
\hline Atap & , & , & , & , & , & , & , & , & , & 0 & . \\
\hline Bahan pengikat/tali & , & , & , & , & . & . & , & , & , & 0 & . \\
\hline Kayu api & , & . & 1 & 1 & , & 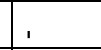 & . & . & 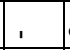 & 0 & . \\
\hline Ekonomi & . & 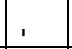 & . & , & , & , & 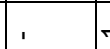 & - & - & i & - \\
\hline Bangunan/perahu & 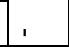 & 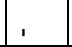 & 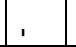 & 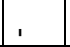 & . & 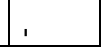 & 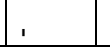 & . & 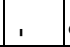 & 0 & . \\
\hline Obat/racun & . & , & , & . & ' & . & , & - & , & 임 &. \\
\hline Makanan & - & - & - & - & - & - & - & - & - & $\stackrel{L}{\forall}$ & . \\
\hline Pertanian & 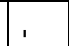 & , & , & , & , & , & , & , & , & 0 & . \\
\hline Jekkau liar & , & - & - & 1 & - & - & . & ' & $\cdot$ & $\bar{N}$ & . \\
\hline Hutan rimba & $r$ & I & - & - & 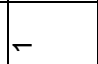 & $r$ & - & - & - & ৪্ল & - \\
\hline Kategori & $\stackrel{\frac{c}{0}}{ }$ & $\stackrel{\overline{0}}{0}$ & 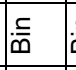 &.$\frac{\bar{c}}{\mathbf{m}}$ & $\frac{\check{0}}{\overline{0}}$ & $\stackrel{\check{0}}{\mathrm{~m}}$ & 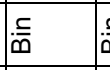 & 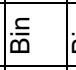 & 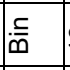 & 我 & ڤ⿳亠二口犬 \\
\hline 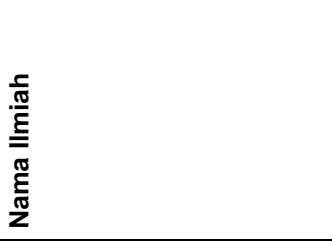 & 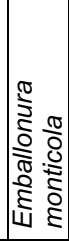 & 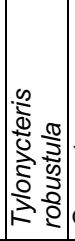 & 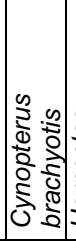 & 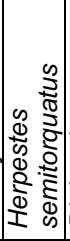 & 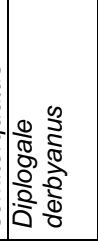 & 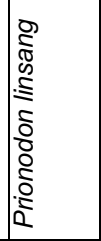 & 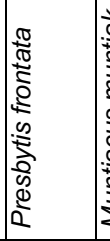 & 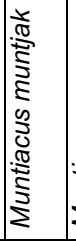 & 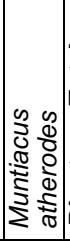 & 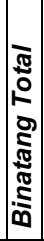 & 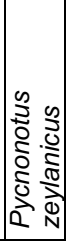 \\
\hline $\begin{array}{l}\bar{\pi} \\
\frac{\pi}{0} \\
\frac{\pi}{\pi} \\
\frac{\pi}{\pi} \\
\frac{\pi}{Z}\end{array}$ & 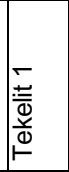 & 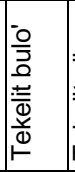 & 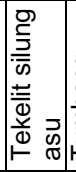 & 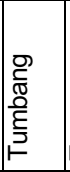 & 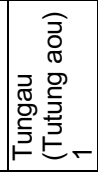 & 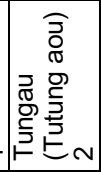 & $\frac{2}{5}$ & סֶ & 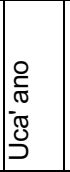 & & 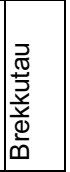 \\
\hline 운 & 웅 & $\bar{q}$ & F & $\mathscr{q}$ & \& & $\stackrel{8}{q}$ & $\mathscr{q}$ & $\hat{f}$ & $\underset{\sim}{\infty}$ & & g \\
\hline
\end{tabular}




\begin{tabular}{|c|c|c|c|c|c|c|c|c|c|c|c|c|c|c|}
\hline 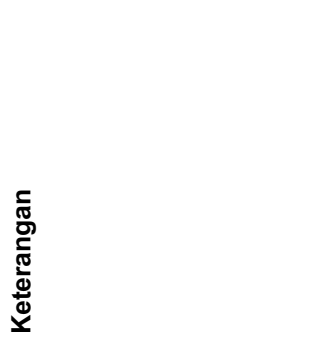 & 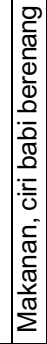 & 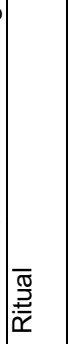 & 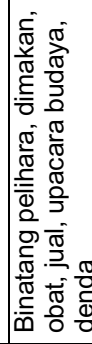 & 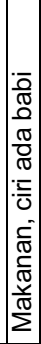 & 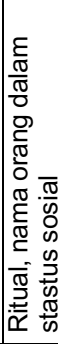 & 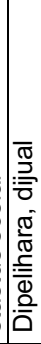 & 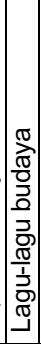 & 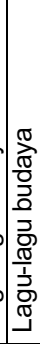 & 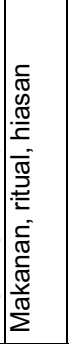 & 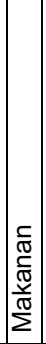 & 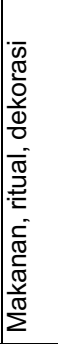 & 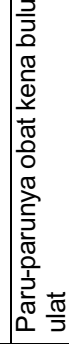 & 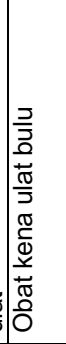 & 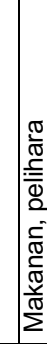 \\
\hline Total kegunaan & N & - & t & N & N & N & $\sim$ & $N$ & $m$ & - & $m$ & N & - & N \\
\hline Dilindungi/mulen & 1 & 1 & . & 1 & , &. &. &. & 1 &. & . & . & 1 & , \\
\hline Status sosial/nama orang &. & . & , &. & . &. &. & , & , &. & , & , & , & , \\
\hline Kerajinan/pewarna & 1 & . & . &. & . &. &. &. & - & 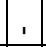 & - & 1 & . & , \\
\hline Upacara/budaya & 1 & - & - & . & . & - & - & - & - &. & - & . & . & , \\
\hline Kebutuhan tak langsung & - & . & . & - & I & 1 & . & . & ' & . & . & ' & . & , \\
\hline Hutan sumber bibit & 1 & . & . &. & I & . & . & , & 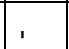 &. & 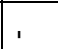 & , & 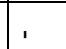 & - \\
\hline Bungkus & . & . & , &. &. & , & , & , & , & . & . & , & , & , \\
\hline Atap & . & . & . & 1 & . &. &. & . & , &. & , & , & , & , \\
\hline Bahan pengikat/tali & 1 & 1 & 1 & 1 & . & 1 & 1 & 1 & 1 & 1 & 1 & 1 & 1 & . \\
\hline Kayu api &. & . & , &. & . &. & . & , & , &. & , & . & , & , \\
\hline Ekonomi &. & . & - &. & . & - & , & . & , & , & 1 & , & 1 & , \\
\hline Bangunan/perahu &. &. & . & . & . &. &. & 1 & . &. & . & 1 &. & . \\
\hline Obat/racun &. & . & - &. & . &. &. & . & , &. & . & - & - & , \\
\hline Makanan & - &. & - & - & . &. & - & - & - & - & - & - & , & - \\
\hline Pertanian & . & . & . & . & I & . & 1 & . & . &. & . & , & . & . \\
\hline Jekkau liar &. & - &. &. & . &. & - &. & 1 & - &. & 1 & 1 & - \\
\hline Hutan rimba & - & - & . & - & . & - & - & - & - & - & - & - &. & - \\
\hline Kategori & ‡ & ڤે & ڤે & ڤ & ڤ & ڤ & ڤે & 今 & 言 & ڤ & ڤે & ”̀ & ڤ & 气 \\
\hline 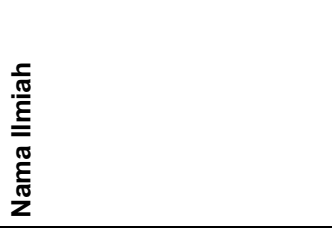 & 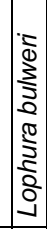 & 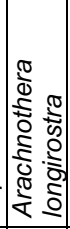 & 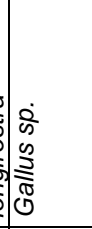 & 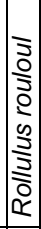 & 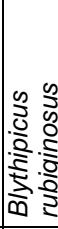 & 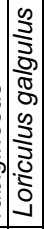 & 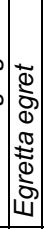 & 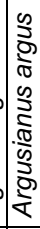 & 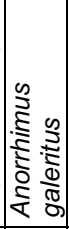 & 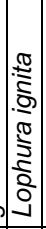 & 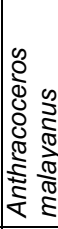 & 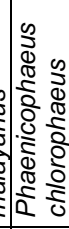 & 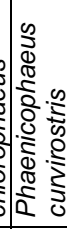 & 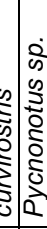 \\
\hline $\begin{array}{l}\bar{\pi} \\
\frac{\pi}{0} \\
\frac{\pi}{\pi} \\
\frac{\pi}{\pi} \\
\frac{\pi}{2}\end{array}$ & 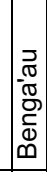 & & $\frac{a}{\stackrel{0}{2}}$ & 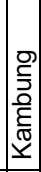 & مי & \begin{tabular}{|l|} 
\\
$\frac{\Xi}{\bar{y}}$ \\
$\underline{\Sigma}$ \\
\end{tabular} & & $\mid \overline{\underline{z}}$ & 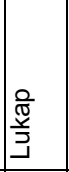 & 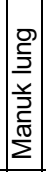 & 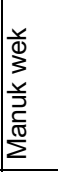 & 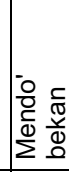 & $\frac{0}{2}$ & 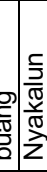 \\
\hline 운 & 只 & in & กิ & in & in & in & 0 & in & $\infty$ & is & 8 & $\overline{0}$ & $\tilde{\sigma}$ & 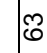 \\
\hline
\end{tabular}




\begin{tabular}{|c|c|c|c|c|c|c|c|c|c|c|c|c|c|c|c|}
\hline 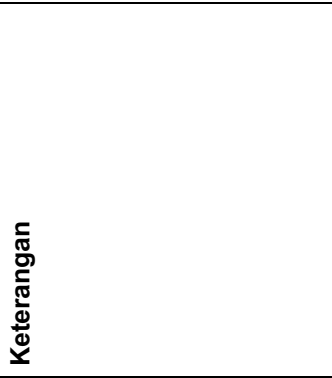 & 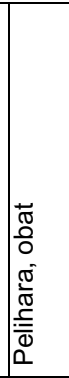 & 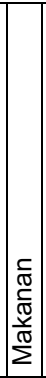 & & $\begin{array}{l}\overline{\widetilde{\pi}} \\
\stackrel{\underline{\underline{\underline{\alpha}}}}{\underline{\underline{\alpha}}} \\
\end{array}$ & 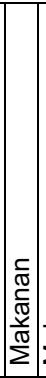 & 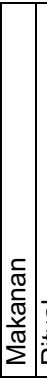 & 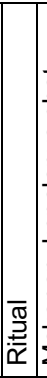 & 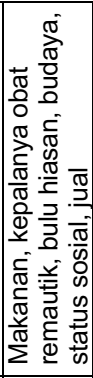 & 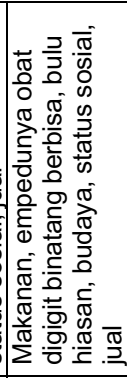 & 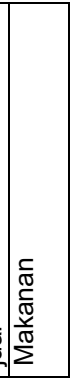 & 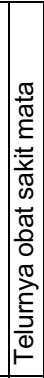 & 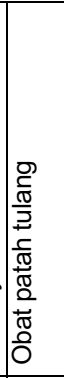 & 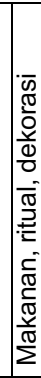 & & 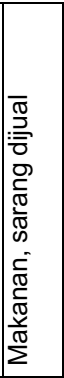 \\
\hline Total kegunaan & $m$ & - & - & - & $m$ & 0. & -5 & 0 & 0 & - & N & - & $m$ & - & N \\
\hline Dilindungi/mulen & , &. & I & , &. &. &. & . & . &. & . &. & , & . & . \\
\hline Status sosial/nama orang & , &. &. & . & - &. &. & - & - & , & . & , & , &. & , \\
\hline Kerajinan/pewarna & , &. &. & . &. &. &. & - & - & . & , & . & - & . & . \\
\hline Upacara/budaya & - &. & - & - & - &. & - & - & - & . & . & , & - & - & . \\
\hline Kebutuhan tak langsung & ' &. & I & I &. & 1 & . & I & I & , & , & I & I & 1 & I \\
\hline Hutan sumber bibit & ' & . & I & 1 &. & 1 & 1 & ' & 1 & 1 & ' & 1 & ' & 1 & 1 \\
\hline Bungkus & . &. & , & . &. &. &. & . & . & . & . & . & , &. & . \\
\hline Atap & , & . & , & . &. &. &. & . & , & . & . & , & , & . & . \\
\hline Bahan pengikat/tali & . &. &. & . &. &. & 1 & . & ' & I & , & 1 & , & 1 & . \\
\hline Kayu api & ' &. & . & 1 &. &. & . & . & ' & . & . & 1 & I & 1 & . \\
\hline Ekonomi & - & . & , & , &. &. &. & - & - & , & , & . & , & . & - \\
\hline Bangunan/perahu & . &. & . & 1 &. &. &. & . & ' & , & . & 1 & ' & . & . \\
\hline Obat/racun & - &. & . & . &. &. &. & - & - & . & - & - & . & 1 & . \\
\hline Makanan &. & - & 1 & 1 & - &. &. & - & - & - & - &. & - &. & - \\
\hline Pertanian & , &. & . & . &. &. &. & . & , & . & . & 1 & I & . & I \\
\hline Jekkau liar & - &. & - &. & - &. &. & . & 1 & . & - & - & . & 1 & . \\
\hline Hutan rimba & - & - & - & - & - &. & . & - & - & - & - & - & - & - & - \\
\hline Kategori & ڤ⿳亠口冋 & ڤ & ڤ & ڤે & \begin{tabular}{|l|} 
\\
$\emptyset$
\end{tabular} & \begin{tabular}{|l|l|}
\multirow{9}{}{} & \\
\end{tabular} & \begin{tabular}{|l|l|}
$\vdots$ \\
$\oplus$
\end{tabular} & ڤ̀ & 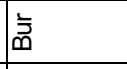 & ڤ & ڤ & ” & ڤ & 言 & ڤે \\
\hline 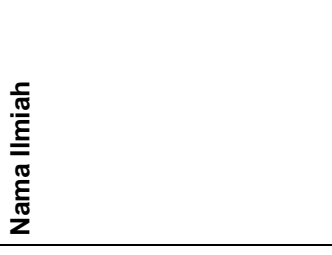 & 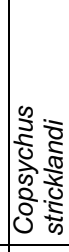 & 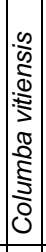 & 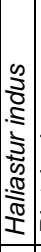 & 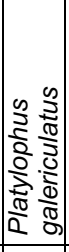 & 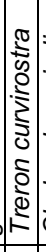 & 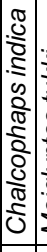 & 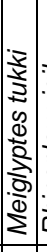 & 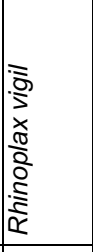 & 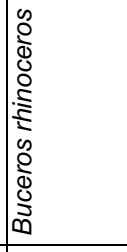 & 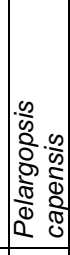 & $\begin{array}{c}\frac{2}{0} \\
\vdots \\
\vdots \\
\vdots \\
\vdots\end{array}$ & 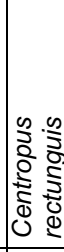 & 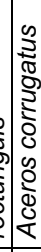 & 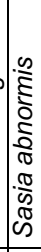 & 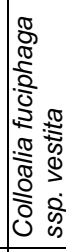 \\
\hline $\begin{array}{l}\bar{\pi} \\
\frac{\pi}{0} \\
\frac{\pi}{\pi} \\
\frac{\varepsilon}{\pi} \\
z\end{array}$ & 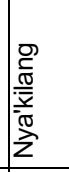 & $\mid \begin{array}{l}\varepsilon \\
\Phi \\
\frac{\sigma}{\omega} \\
\alpha \\
\end{array}$ & & $\stackrel{ \pm}{0}$ & 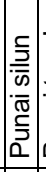 & 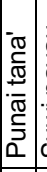 & 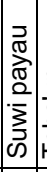 & 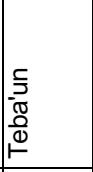 & 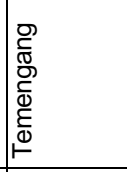 & 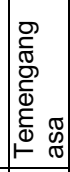 & 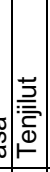 & $\begin{array}{l}\frac{0}{\dot{Q}} \\
\frac{\partial}{2} \\
\underline{\underline{x}}\end{array}$ & 므 & & $\frac{\frac{c}{0}}{\frac{0}{D}}$ \\
\hline 운 & छे & 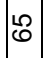 & 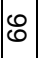 & $\hat{\omega}$ & $\begin{array}{ll}\infty \\
0\end{array}$ & 8 & pir & $\bar{N}$ & $N$ & m & it & 10 & $\stackrel{\infty}{r}$ & $\hat{N}$ & $\infty$ \\
\hline
\end{tabular}




\begin{tabular}{|c|c|c|c|c|c|c|c|c|c|c|c|c|c|c|c|}
\hline 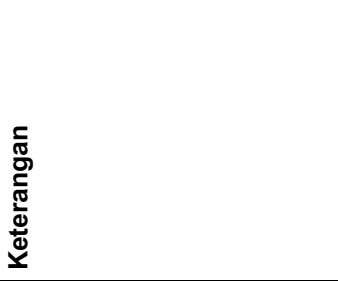 & 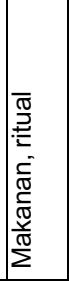 & 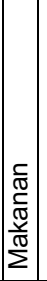 & & 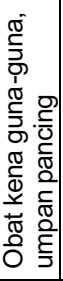 & & 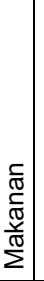 & & 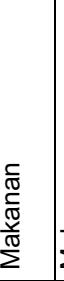 & 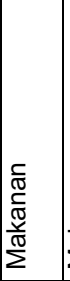 & 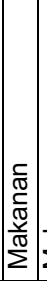 & 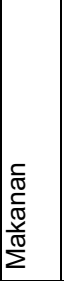 & 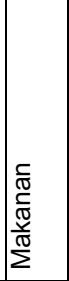 & 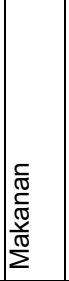 & 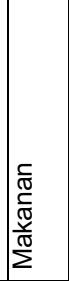 & 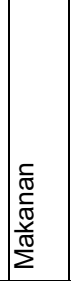 \\
\hline Total kegunaan & $\sim$ & - & ठ্ & m & $m$ & - & $-r$ & - & - & - & - & - & - & - & - \\
\hline Dilindungi/mulen & ' & 1 c & 0 & ' & 0 & I & 0 ०. & ' & ' & 1 & ' & ' & ' & ' & ' \\
\hline Status sosial/nama orang & ' & 1 c & $m$ & 1 & 0 & . & 0 . & ' & ' & 1 & ' & ' & ' & ' & ' \\
\hline Kerajinan/pewarna & ' & 1 & $\infty$ & 1 & 0 & i & \begin{tabular}{l|l}
0 & 1
\end{tabular} & ' & ' & ' & ' & ' & ' & ' & ' \\
\hline Upacara/budaya & - & .15 & $\mp$ & 1 & 0 & . & ○ & ' & 1 & ' & ' & ' & ' & ' & ' \\
\hline Kebutuhan tak langsung & ' & 1. & $N$ & - & - & 1 C & \begin{tabular}{l|l}
0 & 1
\end{tabular} & ' & 1 & 1 & ' & 1 & ' & ' & ' \\
\hline Hutan sumber bibit & ' & 1 c & $N$ & 1 & 0 & $1 \mathrm{c}$ & \begin{tabular}{l|l}
0 & 1
\end{tabular} & ' & ' & ' & ' & ' & ' & ' & ' \\
\hline Bungkus & ' & 16 & 0 & 1 & 0 & 10 & 0 . & ' & ' & ' & ' & ' & ' & ' & ' \\
\hline Atap & ' & . & 0 & 1 & 0 & 16 & \begin{tabular}{l|l}
0 & 1
\end{tabular} & ' & ' & ' & ' & ' & ' & ' & ' \\
\hline Bahan pengikat/tali & ' & . & 0 & 1 & 0 & 10 & \begin{tabular}{l|l}
0 & 1
\end{tabular} & ' & ' & ' & ' & ' & ' & ' & ' \\
\hline Kayu api & ' & 16 & 0 & 1 & 0 & 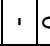 & 0 . 1 & ' & ' & ' & ' & ' & ' & ' & ' \\
\hline Ekonomi & ' & 15 & $\wedge$ & 1 & 0 & \begin{tabular}{l|c}
1 & 0 \\
\end{tabular} & \begin{tabular}{l|l}
0 & 1
\end{tabular} & ' & ' & ' & ' & ' & ' & ' & ' \\
\hline Bangunan/perahu & ' & 1. & 0 & 1 & 0 & 10 & 0 . 1 & ' & ' & 1 & ' & ' & ' & ' & ' \\
\hline Obat/racun & ' & 1. & $\infty$ & - & - & 10 & \begin{tabular}{l|l}
0 & 1
\end{tabular} & ' & ' & 1 & ' & ' & ' & ' & ' \\
\hline Makanan & - & - & ก) & - & - & - & - & - & - & - & - & - & - & - & - \\
\hline Pertanian & ' & 1.5 & 0 & 1 & 0 & $1 \mathrm{c}$ & 0 . 1 & ' & ' & 1 & 1 & 1 & ' & ' & ' \\
\hline Jekkau liar & ' & 1 & の. & - & - & $-F$ & $-F$ & - & 1 & - & - & 1 & - & ' & ' \\
\hline Hutan rimba & - & - & $\hat{N}$ & - & - & - & -1 & - & ' & - & - & ' & - & ' & ' \\
\hline Kategori & ڤે & 言 & న్ల & $\begin{array}{l}0 \\
\mathbb{N} \\
ن\end{array}$ & - & 긴. & $-\stackrel{\cong}{=}$ & $\stackrel{\widetilde{\Xi}}{\underline{\underline{\Xi}}}$ & $\stackrel{\mathbb{\Xi}}{\underline{\Xi}}$ & $\stackrel{\mathbb{\Xi}}{\underline{\Xi}}$ & $\underline{\underline{\underline{\sigma}}}$ & $\stackrel{\mathbb{\Xi}}{=}$ & $\stackrel{\mathbb{D}}{=}$ & $\stackrel{\widetilde{\pi}}{\underline{\underline{N}}}$ & $\stackrel{\widetilde{\pi}}{\underline{\underline{x}}}$ \\
\hline 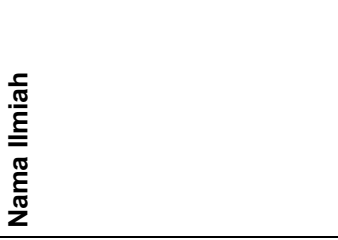 & 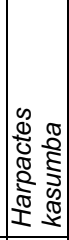 & 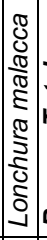 & 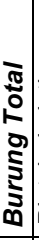 & 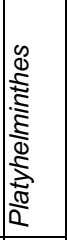 & 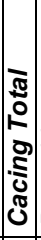 & 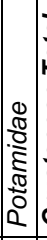 & & 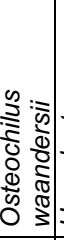 & 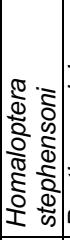 & 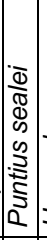 & 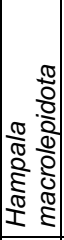 & 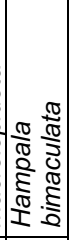 & 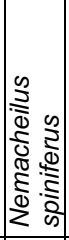 & 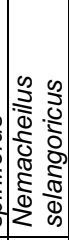 & 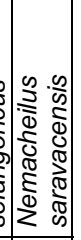 \\
\hline $\begin{array}{l}\bar{\pi} \\
\frac{\pi}{0} \\
\frac{\pi}{\pi} \\
\stackrel{\mathbb{N}}{\pi} \\
\text { Z }\end{array}$ & 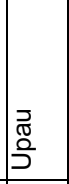 & $\frac{1}{2}$ & & $\bar{\Xi}$ & & $\nu^{2}$ & & 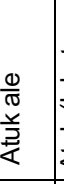 & 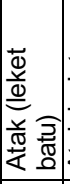 & & 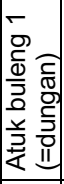 & 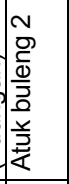 & 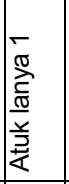 & 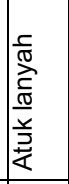 & 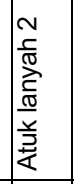 \\
\hline 울 & s & $\infty$ & & $\bar{\infty}_{\infty}$ & & $\infty$ & & $\infty$ & ষ্ঠ & $\infty$ & $œ$ & $\widehat{\infty}$ & \begin{tabular}{|l|}
$\infty$ \\
$\infty$
\end{tabular} & $\infty$ & ৪ \\
\hline
\end{tabular}




\begin{tabular}{|c|c|c|c|c|c|c|c|c|c|c|c|c|c|c|c|c|}
\hline 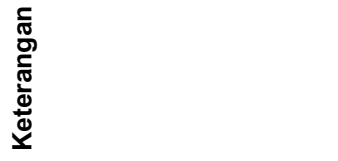 & 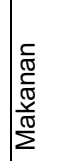 & 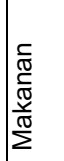 & $\mid \begin{array}{l}\frac{\mathfrak{N}}{\mathbb{N}} \\
\stackrel{\mathbb{N}}{\mathbb{N}} \\
\frac{\mathfrak{N}}{\mathbb{N}} \\
\Sigma\end{array}$ & 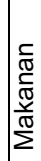 & 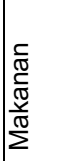 & 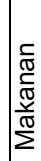 & 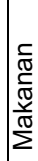 & 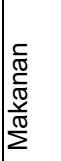 & 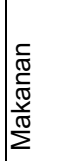 & & 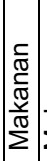 & 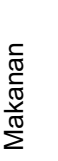 & 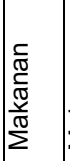 & 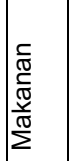 & 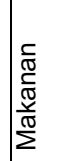 & 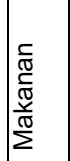 \\
\hline Total kegunaan & - & - & - & - & - & - & - & - & - & - & - & - & - & - & - & $-r$ \\
\hline Dilindungi/mulen & 1 & 1 & 1 & ' & ' & . & 1 & 1 & 1 & 1 & 1 & 1 & 1 & ' & 1 & 1 \\
\hline Status sosial/nama orang & ' & 1 & 1 & ' & ' & ' & 1 & 1 & 1 & 1 & 1 & ' & ' & ' & ' & 1 \\
\hline Kerajinan/pewarna & 1 & 1 & 1 & I & 1 & ' & 1 & 1 & 1 & 1 & 1 & 1 & ' & ' & ' & ' \\
\hline Upacara/budaya & ' & 1 & 1 & 1 & 1 & ' & 1 & 1 & 1 & 1 & 1 & ' & ' & ' & ' & ' \\
\hline Kebutuhan tak langsung & 1 & 1 & 1 & 1 & 1 & 1 & 1 & 1 & 1 & 1 & 1 & 1 & 1 & ' & 1 & ' \\
\hline Hutan sumber bibit & 1 & 1 & 1 & 1 & 1 & ' & 1 & 1 & 1 & 1 & 1 & 1 & ' & ' & ' & ' \\
\hline Bungkus & 1 & 1 & 1 & I & ' & ' & 1 & 1 & 1 & 1 & 1 & 1 & 1 & ' & ' & ' \\
\hline Atap & 1 & 1 & 1 & I & ' & ' & 1 & 1 & 1 & 1 & 1 & 1 & 1 & ' & ' & ' \\
\hline Bahan pengikat/tali & 1 & 1 & 1 & 1 & ' & ' & 1 & 1 & 1 & 1 & 1 & 1 & ' & ' & 1 & ' \\
\hline Kayu api & 1 & 1 & 1 & 1 & 1 & 1 & 1 & 1 & 1 & 1 & 1 & 1 & ' & ' & 1 & ' \\
\hline Ekonomi & 1 & ' & 1 & 1 & ' & ' & 1 & 1 & 1 & 1 & 1 & ' & ' & ' & ' & ' \\
\hline Bangunan/perahu & 1 & 1 & 1 & 1 & 1 & 1 & 1 & 1 & 1 & 1 & 1 & 1 & ' & $'$ & 1 & ' \\
\hline Obat/racun & 1 & 1 & 1 & ' & 1 & 1 & 1 & 1 & 1 & 1 & 1 & 1 & 1 & 1 & ' & 1 \\
\hline Makanan & - & - & - & - & - & - & - & - & - & - & - & - & - & - & - & - \\
\hline Pertanian & ' & 1 & 1 & . & ' & . & 1 & 1 & 1 & 1 & 1 & 1 & 1 & 1 & ' & 1 \\
\hline Jekkau liar & - & - & 1 & 1 & - & - & ' & - & 1 & 1 & 1 & ' & - & ' & ' & - \\
\hline Hutan rimba & - & - & 1 & . & - & - & ' & - & ' & ' & . & ' & - & ' & ' & - \\
\hline Kategori & $\stackrel{\widetilde{\sigma}}{\underline{\underline{g}}}$ & $\stackrel{\mathbb{g}}{\underline{\underline{y}}}$ & $\stackrel{\mathbb{\Xi}}{\underline{\underline{x}}}$ & $\stackrel{\mathbb{N}}{=}$ & $\stackrel{\mathbb{g}}{\underline{\underline{y}}}$ & $\stackrel{\mathbb{\Xi}}{=}$ & $\stackrel{\mathbb{\pi}}{\underline{\underline{\Xi}}}$ & $\stackrel{\mathbb{( \sigma}}{\underline{\underline{y}}}$ & $\underline{\underline{\widetilde{g}}}$ & $\stackrel{\mathbb{\sigma}}{\underline{\underline{T}}}$ & $\stackrel{\mathbb{F}}{\underline{\Xi}}$ & $\underline{\underline{\pi}}$ & $\stackrel{\mathbb{Z}}{\underline{\underline{T}}}$ & $\stackrel{\mathbb{\Xi}}{=}$ & $\stackrel{\mathbb{\pi}}{\underline{\underline{\Xi}}}$ & $\stackrel{\mathbb{T}}{\underline{\underline{N}}}$ \\
\hline $\begin{array}{l}\frac{c}{\frac{\pi}{\pi}} \\
\underline{\underline{\xi}} \\
\frac{\pi}{\varepsilon} \\
\frac{\pi}{2} \\
\end{array}$ & 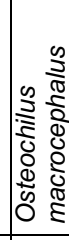 & 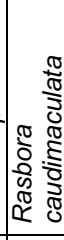 & 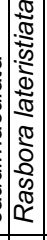 & 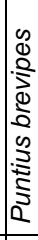 & 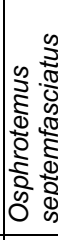 & 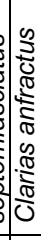 & 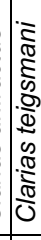 & 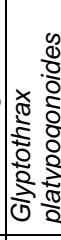 & 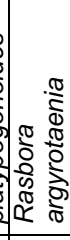 & 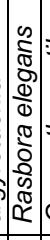 & 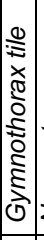 & 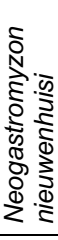 & 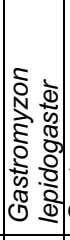 & 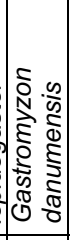 & 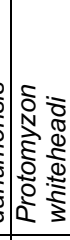 & 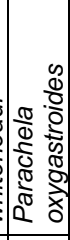 \\
\hline 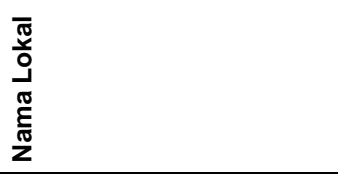 & 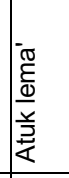 & 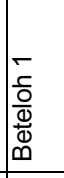 & $\mid \begin{array}{l}\bar{c} \\
\frac{c}{0} \\
\frac{0}{\Phi} \\
\Phi \\
\infty\end{array}$ & & $\begin{array}{l}\frac{0}{\mathscr{N}} \\
\stackrel{x}{2}\end{array}$ & 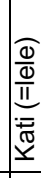 & 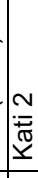 & 蒙 & 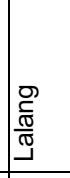 & $\begin{array}{l}N \\
0 \\
\frac{D}{\widetilde{N}} \\
\frac{\pi}{\widetilde{J}}\end{array}$ & 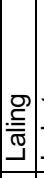 & 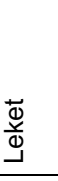 & 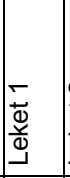 & $\begin{array}{l}\sim \\
\stackrel{N}{\omega} \\
\frac{\omega}{\omega} \\
\end{array}$ & 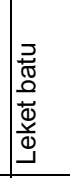 & $\begin{array}{l}- \\
\Phi \\
\stackrel{0}{0} \\
\end{array}$ \\
\hline 운 & $\bar{\sigma}$ & ๙ั & ळ & & 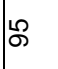 & 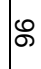 & $\hat{\circ}$ & $\infty$ & প & ৪ & 앙 & ๙ָ & $\stackrel{\dddot{\rho}}{\circ}$ & $\stackrel{\Xi}{\circ}$ & $\stackrel{2}{\varrho}$ & 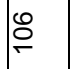 \\
\hline
\end{tabular}




\begin{tabular}{|c|c|c|c|c|c|c|c|c|c|c|c|c|c|c|c|}
\hline 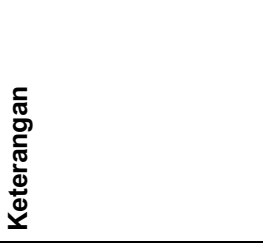 & 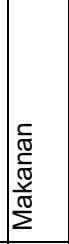 & 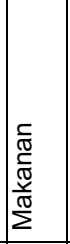 & 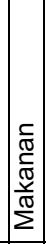 & 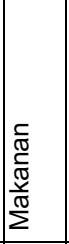 & 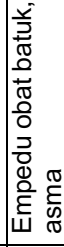 & 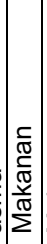 & 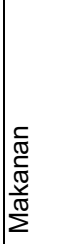 & 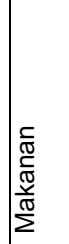 & 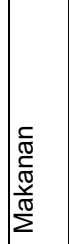 & 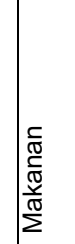 & 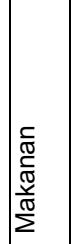 & 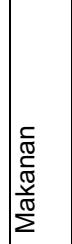 & 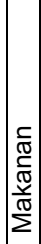 & 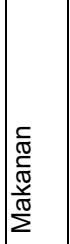 & 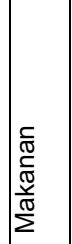 \\
\hline Total kegunaan & - & - & - & - & $m$ & $m$ & N & - & $r$ & $r$ & N & - & - & $-r$ & - \\
\hline Dilindungi/mulen & 1 & 1 & 1 & 1 & 1 & 1 & ' & 1 & 1 & 1 & ' & 1 & 1 & 1 & 1 \\
\hline Status sosial/nama & 1 & I & 1 & 1 & ' & - & . & 1 & 1 & 1 & 1 & 1 & 1 & 1 & 1 \\
\hline Kerajinan/pewarna & 1 & ' & 1 & I & ' & 1 & 1 & 1 & 1 & ' & ' & ' & 1 & 1 & 1 \\
\hline Upacara/budaya & 1 & ' & 1 & . & 1 & 1 & . & ' & , & ' & ' & ' & 1 & . & , \\
\hline Kebutuhan tak & 1 & ' & 1 & 1 & 1 & 1 & 1 & 1 & 1 & 1 & ' & 1 & 1 & 1 & 1 \\
\hline Hutan sumber bibit & 1 & ' & 1 & 1 & 1 & 1 & 1 & 1 & 1 & 1 & 1 & ' & 1 & 1 & 1 \\
\hline Bungkus & 1 & ' & 1 & 1 & 1 & 1 & 1 & 1 & 1 & 1 & 1 & ' & . & 1 & 1 \\
\hline Atap & 1 & 1 & 1 & 1 & 1 & 1 & 1 & ' & 1 & ' & ' & 1 & 1 & 1 & 1 \\
\hline Bahan pengikat/tali & 1 & ' & 1 & 1 & 1 & 1 & 1 & ' & 1 & 1 & ' & ' & 1 & 1 & 1 \\
\hline Kayu api & 1 & 1 & 1 & 1 & 1 & 1 & 1 & ' & 1 & 1 & ' & ' & ' & 1 & 1 \\
\hline Ekonomi & 1 & 1 & 1 & I & - & - & - & ' & 1 & 1 & - & ' & 1 & 1 & 1 \\
\hline Bangunan/perahu & ' & ' & 1 & I & 1 & 1 & 1 & ' & 1 & 1 & I & ' & 1 & I & ' \\
\hline Obat/racun & 1 & 1 & 1 & 1 & - & 1 & 1 & ' & 1 & 1 & 1 & ' & 1 & 1 & ' \\
\hline Makanan & - & - & - & - & - & - & - & - & - & - & - & - & - & - & - \\
\hline Pertanian & 1 & ' & 1 & 1 & 1 & 1 & 1 & 1 & 1 & 1 & ' & 1 & 1 & ' & 1 \\
\hline Jekkau liar & ' & ' & - & - & - & - & - & ' & ' & - & - & - & - & - & ' \\
\hline Hutan rimba & 1 & ' & - & - & - & - & - & ' & ' & - & - & - & - & - & ' \\
\hline Kategori & $\stackrel{\mathbb{\pi}}{\underline{\underline{T}}}$ & $\stackrel{\mathbb{T}}{\underline{\underline{T}}}$ & $\stackrel{\mathbb{T}}{\underline{\underline{x}}}$ & $\stackrel{\mathbb{g}}{\underline{\underline{y}}}$ & $\stackrel{\mathbb{T}}{\underline{\underline{T}}}$ & $\stackrel{\mathbb{N}}{\underline{\Xi}}$ & $\stackrel{\mathbb{g}}{\underline{\underline{y}}}$ & $\stackrel{\mathbb{g}}{\underline{\underline{y}}}$ & $\stackrel{\widetilde{\Xi}}{\underline{\underline{N}}}$ & $\stackrel{\mathbb{P}}{\underline{\underline{T}}}$ & $\stackrel{\Xi}{\underline{\underline{N}}}$ & $\stackrel{\Xi}{\underline{\underline{N}}}$ & 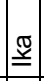 & $\stackrel{\widetilde{T}}{\underline{\underline{N}}}$ & $\stackrel{\mathbb{\Omega}}{\underline{\underline{y}}}$ \\
\hline 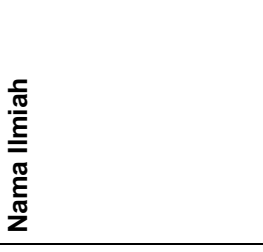 & 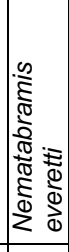 & 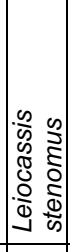 & 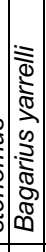 & 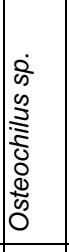 & 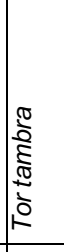 & 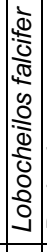 & 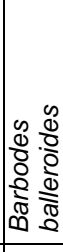 & 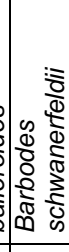 & 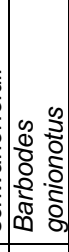 & 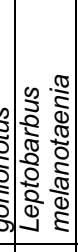 & 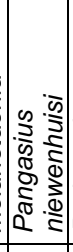 & 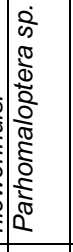 & 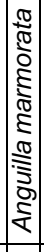 & 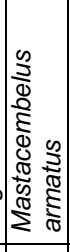 & 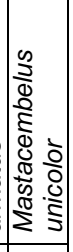 \\
\hline 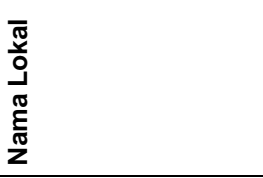 & 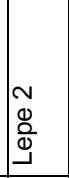 & 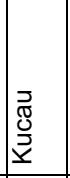 & + & 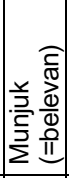 & $\frac{x}{0}$ & 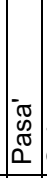 & $\begin{array}{l}\frac{2}{\pi} \\
\tilde{\pi} \\
\tilde{\pi}\end{array}$ & 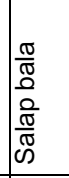 & $\begin{array}{l}\frac{1}{1} \\
\frac{\partial}{2} \\
\frac{0}{\pi} \\
\frac{\pi}{\pi} \\
\omega\end{array}$ & 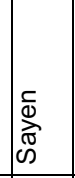 & 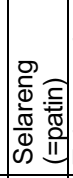 & 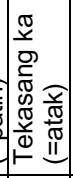 & 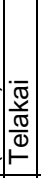 & $\begin{array}{l}- \\
\frac{\sigma}{\sigma} \\
\frac{\sigma}{\omega} \\
\end{array}$ & 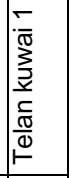 \\
\hline 은 & $\stackrel{ }{\circ}$ & $\stackrel{\infty}{\circ}$ & $\stackrel{2}{\circ}$ & $\stackrel{ }{=}$ & $\Xi$ & $\cong$ & $\stackrel{m}{\rightleftarrows}$ & $\stackrel{\Xi}{\rightleftarrows}$ & $\stackrel{10}{=}$ & $\stackrel{\wp}{\rightleftharpoons}$ & 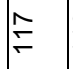 & $\stackrel{\infty}{\mp}$ & $\stackrel{\circledast}{\mp}$ & $\stackrel{શ}{\cong}$ & $\stackrel{\check{N}}{\leftarrow}$ \\
\hline
\end{tabular}




\begin{tabular}{|c|c|c|c|c|c|c|c|c|c|c|c|c|c|c|c|c|c|c|c|}
\hline 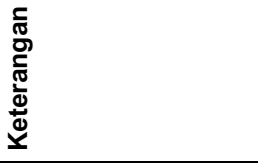 & 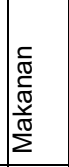 & \begin{tabular}{|l|}
$\frac{C}{\mathbb{N}}$ \\
$\stackrel{\mathbb{T}}{\mathbb{N}}$ \\
$\frac{\mathbb{N}}{\mathbb{N}}$ \\
$\Sigma$
\end{tabular} & 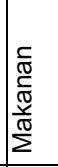 & 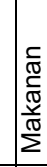 & 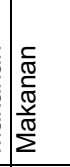 & 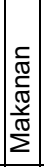 & 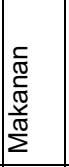 & 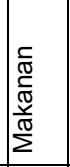 & 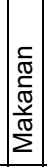 & 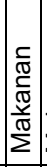 & 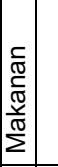 & 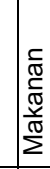 & 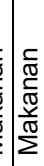 & 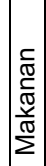 & 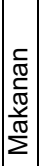 & 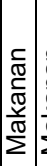 & & 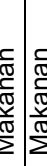 & 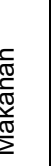 \\
\hline Total kegunaan & - & $\sim$ & - & - & - & - & - & - & - & $m$. & -18 & - & - & - & - & - & $-r$ & $-r$ & - \\
\hline Dilindungi/mulen & 1 & 1 & 1 & ' & 1 & 1 & 1 & 1 & 1 & 1 & \begin{tabular}{l|l}
1 & 0 \\
\end{tabular} & 1 & 1 & 1 & ' & ' & ' & ' & ' \\
\hline Status sosial/nama & 1 & 1 & 1 & ' & 1 & 1 & I & 1 & 1 & - & \begin{tabular}{l|l} 
& $N$ \\
\end{tabular} & $\begin{array}{ll} \\
\end{array}$ & 1 & 1 & 1 & ' & ' & ' & ' \\
\hline Kerajinan/pewarna & 1 & 1 & 1 & ' & ' & 1 & 1 & 1 & 1 & 1 & $\begin{array}{lll}1 & 0 \\
\end{array}$ & $\begin{array}{ll}1 \\
\end{array}$ & 1 & 1 & ' & ' & ' & ' & ' \\
\hline Upacara/budaya & ' & 1 & 1 & ' & I & 1 & ' & ' & 1 & 1 & 10 & . & ' & 1 & ' & ' & ' & 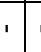 & ' \\
\hline Kebutuhan tak & 1 & 1 & 1 & 1 & 1 & 1 & 1 & 1 & 1 & 1 & 10 & 1 & 1 & 1 & ' & 1 & ' & tha & ' \\
\hline Hutan sumber bibit & 1 & 1 & 1 & ' & 1 & ' & 1 & 1 & 1 & 1 & 10 & 1 & 1 & 1 & ' & ' & ' & 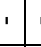 & ' \\
\hline Bungkus & 1 & 1 & 1 & 1 & 1 & 1 & 1 & 1 & 1 & 1 & 10 & 1 & 1 & 1 & ' & ' & ' & 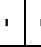 & ' \\
\hline Atap & 1 & 1 & I & ' & 1 & 1 & 1 & 1 & 1 & 1 & \begin{tabular}{l|l}
1 & 0 \\
\end{tabular} & $\begin{array}{ll} \\
\end{array}$ & 1 & 1 & ' & 1 & 1 & ' & ' \\
\hline Bahan pengikat/tali & 1 & 1 & 1 & ' & 1 & 1 & 1 & 1 & $\cdot$ & 1 & 10 & 1 & 1 & 1 & ' & ' & ' & ' & ' \\
\hline Kayu api & 1 & 1 & 1 & ' & 1 & 1 & 1 & 1 & 1 & 1 & 10 & 1 & I & 1 & ' & 1 & ' & tha & ' \\
\hline Ekonomi & 1 & - & 1 & ' & 1 & 1 & I & 1 & 1 & - & \begin{tabular}{|l|l|l}
1 & 0
\end{tabular} & $\begin{array}{ll}0 & 1\end{array}$ & 1 & 1 & ' & ' & ' & 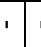 & ' \\
\hline Bangunan/perahu & 1 & 1 & 1 & ' & 1 & ' & 1 & 1 & 1 & 1 & 10 & $\begin{array}{ll} & 1 \\
\end{array}$ & 1 & 1 & 1 & ' & 1 & L & ' \\
\hline Obat/racun & 1 & 1 & 1 & 1 & 1 & 1 & ' & 1 & 1 & 1 & \begin{tabular}{l|l} 
& - \\
\end{tabular} & -1 & . & 1 & ' & ' & ' & ' & ' \\
\hline Makanan & - & - & - & - & - & - & - & - & - & - & -10 & - & - & - & - & - & - & - & - \\
\hline Pertanian & 1 & 1 & 1 & ' & 1 & 1 & ' & 1 & 1 & 1 & 10 & 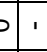 & . & 1 & 1 & . & ' & , & ' \\
\hline Jekkau liar & 1 & - & 1 & . & - & - & - & 1 & 1 & - & -1 & $\bar{v}-$ & - & - & - & - & - & & - \\
\hline Hutan rimba & 1 & - & 1 & ' & - & - & - & 1 & 1 & - & -1 & $\hat{v}-$ & - & - & - & - & - & $r$ & - \\
\hline Kategori & $\stackrel{\mathbb{N}}{\underline{\underline{T}}}$ & $\stackrel{\mathbb{P}}{\underline{\underline{y}}}$ & $\stackrel{\mathbb{E}}{\underline{\underline{\Xi}}}$ & $\stackrel{\mathbb{\pi}}{\underline{\Xi}}$ & $\stackrel{\mathbb{\Xi}}{\underline{\underline{\Xi}}}$ & $\stackrel{\mathbb{\Xi}}{\underline{\underline{N}}}$ & 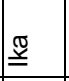 & $\stackrel{\mathbb{g}}{\underline{\underline{y}}}$ & $\stackrel{\mathbb{N}}{\underline{\Xi}}$ & 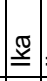 & $\stackrel{\Xi}{\stackrel{\Xi}{2}}$ & 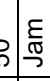 & $\frac{E}{\stackrel{\sigma}{\sim}}$ & 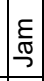 & \begin{tabular}{|l|} 
\\
\multirow{T}{T}{} \\
\end{tabular} & $\begin{array}{c}E \\
\tilde{\Phi} \\
\mathcal{S} \\
\end{array}$ & & & 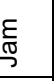 \\
\hline 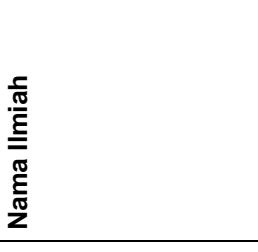 & 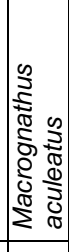 & 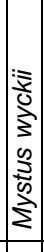 & 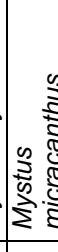 & 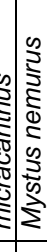 & 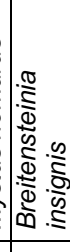 & 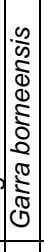 & 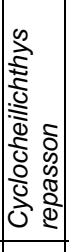 & 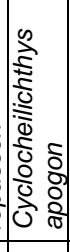 & 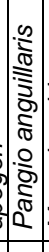 & 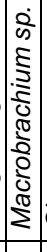 & 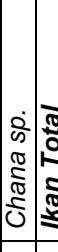 & & $\begin{array}{l}\frac{0}{2} \\
0 \\
0 \\
\frac{2}{2} \\
0 \\
0 \\
\frac{1}{2} \\
\frac{1}{2} \\
\end{array}$ & $\bar{z}$ & 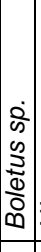 & $\bar{z}$ & 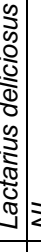 & & $\bar{z}$ \\
\hline 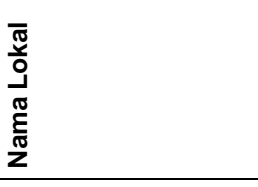 & 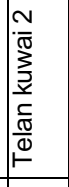 & 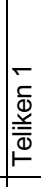 & 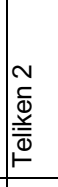 & 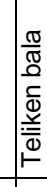 & 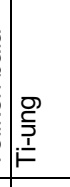 & $\frac{\varepsilon}{\frac{\varepsilon}{D}}$ & 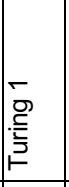 & 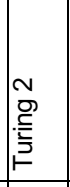 & 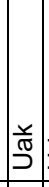 & $\mid \begin{array}{c}0 \\
\frac{D}{\pi} \\
\frac{\pi}{D} \\
\end{array}$ & \begin{tabular}{|l|} 
\\
\\
\\
\end{tabular} & $\begin{array}{l}\overline{0} \\
\frac{d}{0} \\
\underline{d} \\
\underline{y}\end{array}$ & $\frac{0}{\frac{0}{2}}$ & 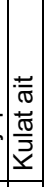 & \begin{tabular}{|l|}
$\frac{\sigma}{\sigma}$ \\
$\frac{\sigma}{2}$ \\
$\frac{\vec{\pi}}{\overline{2}}$ \\
$\underline{\underline{y}}$ \\
\end{tabular} & 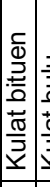 & 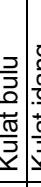 & & 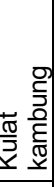 \\
\hline 은 & $\stackrel{N}{\mp}$ & $\stackrel{\sim}{\sim}$ & 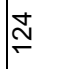 & 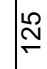 & 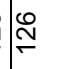 & $\stackrel{\mathbb{N}}{\cong}$ & $\stackrel{\infty}{\stackrel{\infty}{\sim}}$ & $\stackrel{尺}{\cong}$ & প্লি & $\bar{m}$ & 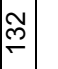 & $\stackrel{m}{\longrightarrow}$ & $\stackrel{\square}{m}$ & $\stackrel{\infty}{\mathscr{2}}$ & $\mid \begin{array}{l}0 \\
\stackrel{m}{-}\end{array}$ & $\hat{m}$ & $\stackrel{\infty}{\stackrel{\infty}{c})}$ & 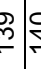 & \& \\
\hline
\end{tabular}




\begin{tabular}{|c|c|c|c|c|c|c|c|c|c|c|c|c|c|c|c|c|}
\hline 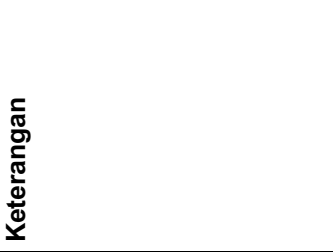 & 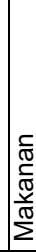 & 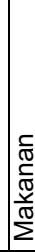 & 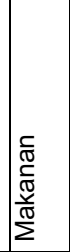 & 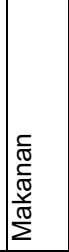 & $\begin{array}{l}\frac{1}{\pi} \\
\frac{\pi}{\pi} \\
\frac{\pi}{\pi} \\
\frac{\pi}{\pi} \\
\sum\end{array}$ & 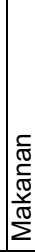 & 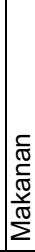 & 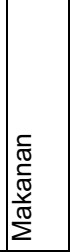 & $\begin{array}{l}\frac{C}{\mathbb{N}} \\
\frac{\mathrm{T}}{\mathbb{N}} \\
\frac{\mathbb{N}}{\mathbb{T}} \\
\Sigma\end{array}$ & 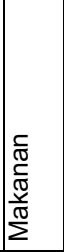 & 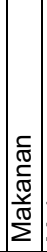 & 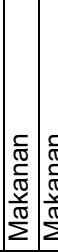 & 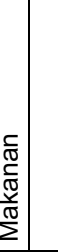 & 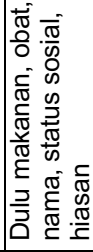 & 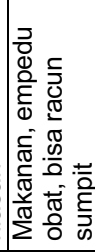 & 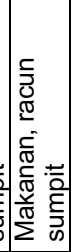 \\
\hline Total kegunaan & - & - & - & - & - & - & - & - & - & - & - & $-r$ & $-\bar{N}$ & - & $m$ & N \\
\hline Dilindungi/mulen & ' & ' & 1 & 1 & ' & ' & 1 & ' & 1 & ' & 1 & 1. & . 0 & 1 & 1 & ' \\
\hline Status sosial/nama orang & ' & ' & 1 & 1 & ' & ' & 1 & 1 & 1 & ' & 1 & 11 & . 0 & - & 1 & ' \\
\hline Kerajinan/pewarna & 1 & ' & 1 & 1 & ' & ' & 1 & 1 & 1 & ' & 1 & 11 & 10 & 1 & 1 & ' \\
\hline Upacara/budaya & . & ' & . & ' & ' & ' & 1 & 1 & 1 & 1 & ' & . 1 & . 0 & . & - & ' \\
\hline Kebutuhan tak langsung & ' & ' & 1 & ' & ' & ' & 1 & ' & 1 & ' & 1 & 11 & 10 & 1 & 1 & ' \\
\hline Hutan sumber bibit & ' & ' & . & 1 & ' & ' & 1 & . & 1 & ' & 1 & 1.1 & 10 & 1 & ' & ' \\
\hline Bungkus & ' & ' & 1 & 1 & ' & ' & 1 & 1 & 1 & ' & . & \begin{tabular}{l|l}
1 \\
\end{tabular} & 10 & 1 & 1 & 1 \\
\hline Atap & ' & ' & 1 & 1 & ' & I & 1 & 1 & 1 & ' & ' & 1,1 & 10 & 1 & 1 & ' \\
\hline Bahan pengikat/tali & 1 & ' & I & ' & ' & I & 1 & 1 & 1 & ' & 1 & 1.1 & 10 & 1 & 1 & ' \\
\hline Kayu api & ' & ' & 1 & 1 & ' & 1 & 1 & 1 & 1 & ' & 1 & 1. & 10 & 1 & 1 & ' \\
\hline Ekonomi & ' & ' & 1 & 1 & $'$ & 1 & 1 & 1 & 1 & ' & 1 & $1 \quad 1$ & 10 & 1 & 1 & 1 \\
\hline Bangunan/perahu & ' & ' & 1 & 1 & ' & ' & 1 & 1 & 1 & ' & 1 & 11 & 10 & 1 & ' & 1 \\
\hline Obat/racun & 1 & 1 & 1 & 1 & ' & ' & 1 & 1 & 1 & ' & 1 & 1.1 & 10 & 1 & - & - \\
\hline Makanan & - & - & - & - & - & - & - & - & - & - & - & $-\sigma$ & $-\bar{N}$ & . & - & - \\
\hline Pertanian & 1 & I & 1 & 1 & . & ' & 1 & 1 & 1 & ' & 1 & 1. & 10 & 1 & ' & 1 \\
\hline Jekkau liar & ' & - & - & - & , & - & . & 1 & - & ' & - & $-r$ & $-\stackrel{20}{2}$ & 1 & - & 1 \\
\hline Hutan rimba & - & F & 1 & - & - & - & - & - & - & - & - &. & $-\cong$ & - & - & - \\
\hline Kategori & 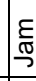 & $\underset{\mathcal{E}}{\stackrel{E}{\mathcal{T}}}$ & 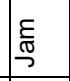 & $\begin{array}{l}\varepsilon \\
\text { T్ } \\
\end{array}$ & $\underset{\substack{\tilde{\sigma} \\
\mathcal{D}}}{ }$ & $\begin{array}{l}\frac{E}{\sigma} \\
\text { T) }\end{array}$ & $\frac{\varepsilon}{\frac{\varepsilon}{\sigma}}$ & $\underset{\sim}{\stackrel{E}{\widetilde{T}}}$ & $\frac{E}{\widetilde{T}}$ & $\frac{\varepsilon}{\widetilde{\sigma}}$ & $\begin{array}{l}\frac{\varepsilon}{\sigma} \\
\stackrel{\sigma}{\sigma}\end{array}$ & 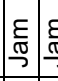 & $\stackrel{\varepsilon}{\stackrel{\sigma}{\sigma}} \overline{\text { N }}$ & $\begin{array}{l}\stackrel{0}{0} \\
\propto \\
\propto\end{array}$ & $\begin{array}{l}\stackrel{0}{\otimes} \\
\propto\end{array}$ & 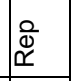 \\
\hline 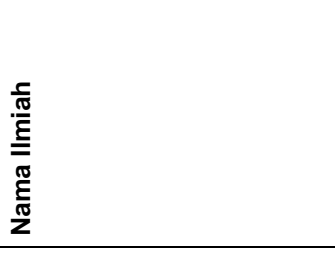 & $\bar{z}$ & 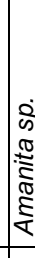 & $\bar{z}$ & 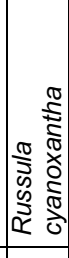 & & ¿ & 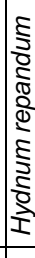 & 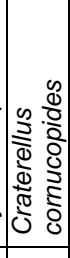 & $\bar{z}$ & $\bar{z}$ & & 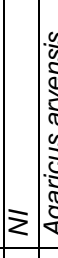 & 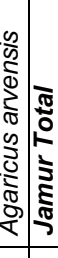 & 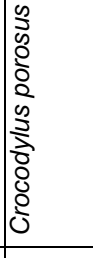 & 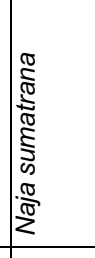 & 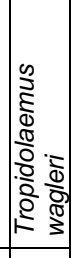 \\
\hline 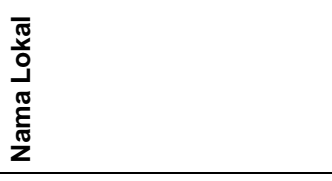 & $\begin{array}{l}\frac{\bar{a}}{\pi} \\
\frac{\pi}{\frac{\pi}{2}} \\
\underline{\underline{\pi}}\end{array}$ & & 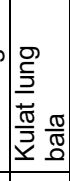 & 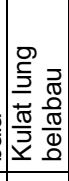 & $\left\{\begin{array}{l}\frac{c}{\frac{\pi}{\pi}} \\
\frac{\alpha}{\frac{\pi}{\pi}} \\
\frac{\pi}{2}\end{array}\right.$ & $\begin{array}{l}\frac{0}{3} \\
\frac{\partial}{0} \\
\frac{\pi}{2} \\
\underline{2}\end{array}$ & $\begin{array}{l}\frac{.0}{\overline{3}} \\
\frac{0}{0} \\
\frac{\pi}{0} \\
\frac{1}{2} \\
\end{array}$ & $\begin{array}{l}\frac{\pi}{\pi} \\
\frac{\pi}{\pi} \\
\frac{\pi}{2} \\
\underline{\underline{T}} \\
\end{array}$ & 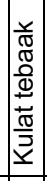 & 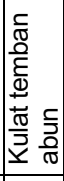 & 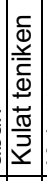 & 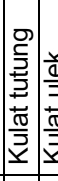 & 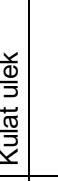 & 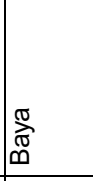 & 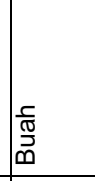 & 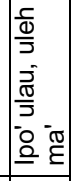 \\
\hline 은 & 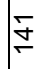 & 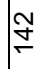 & 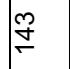 & $\mid \frac{1}{8}$ & $\stackrel{L}{\mathscr{L}}$ & & 守 & $\stackrel{\infty}{\longleftarrow}$ & $\underset{9}{\square}$ & $\stackrel{\circ}{\circ}$ & & 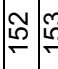 & 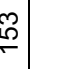 & 苞 & م & 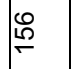 \\
\hline
\end{tabular}




\begin{tabular}{|c|c|c|c|c|c|c|c|c|c|c|c|c|c|c|}
\hline 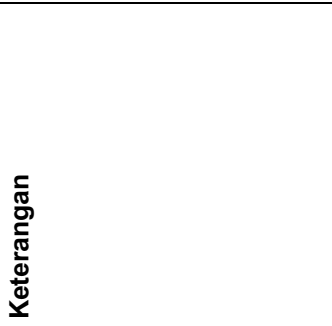 & 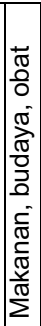 & 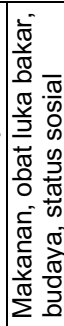 & 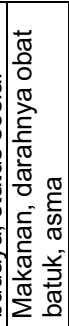 & 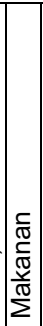 & 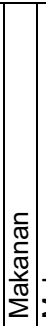 & 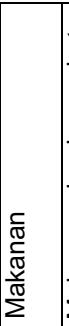 & 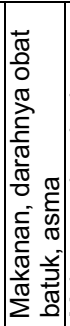 & 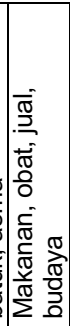 & 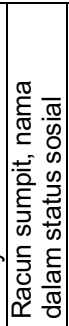 & 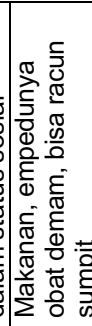 & 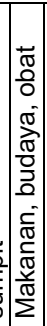 & 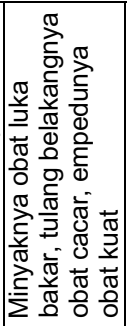 & 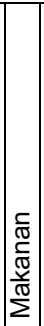 & 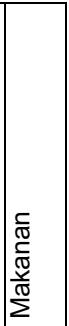 \\
\hline Total kegunaan & $m$ & t & N & - & - & - & N & t & - & t & $m$ & $m$ & - & - \\
\hline Dilindungi/mulen & 1 & 1 & 1 & 1 & 1 & 1 & 1 & 1 & ' & ' & ' & ' & ' & ' \\
\hline Status sosial/nama orang & 1 & - & ' & 1 & ' & ' & ' & ' & ' & - & ' & ' & ' & ' \\
\hline Kerajinan/pewarna & 1 & 1 & 1 & 1 & 1 & 1 & ' & 1 & ' & 1 & 1 & ' & ' & 1 \\
\hline Upacara/budaya & - & - & ' & 1 & 1 & , & ' & - & 1 & - & - & , & ' & 1 \\
\hline Kebutuhan tak langsung & ' & 1 & ' & 1 & 1 & 1 & 1 & 1 & 1 & ' & 1 & ' & 1 & 1 \\
\hline Hutan sumber bibit & 1 & I & ' & 1 & 1 & 1 & ' & 1 & ' & ' & 1 & ' & 1 & 1 \\
\hline Bungkus & 1 & 1 & 1 & 1 & 1 & 1 & ' & 1 & ' & ' & ' & ' & ' & 1 \\
\hline Atap & 1 & 1 & ' & 1 & 1 & 1 & ' & 1 & 1 & ' & 1 & ' & 1 & ' \\
\hline Bahan pengikat/tali & 1 & . & ' & 1 & 1 & 1 & ' & ' & ' & ' & 1 & ' & 1 & ' \\
\hline Kayu api & 1 & 1 & ' & 1 & 1 & 1 & ' & 1 & ' & ' & 1 & ' & 1 & ' \\
\hline Ekonomi & 1 & 1 & 1 & 1 & 1 & 1 & ' & - & 1 & ' & 1 & - & ' & 1 \\
\hline Bangunan/perahu & 1 & 1 & ' & 1 & 1 & 1 & ' & 1 & ' & ' & 1 & ' & 1 & . \\
\hline Obat/racun & - & - & - & 1 & 1 & 1 & - & - & - & - & - & - & 1 & 1 \\
\hline Makanan & - & - & - & - & - & - & - & - & ' & - & - & - & - & - \\
\hline Pertanian & 1 & 1 & 1 & 1 & 1 & 1 & 1 & 1 & ' & ' & 1 & ' & 1 & ' \\
\hline Jekkau liar & 1 & - & ' & - & 1 & 1 & ' & - & 1 & - & & - & - & - \\
\hline Hutan rimba & - & - & - & - & - & - & - & - & - & - & - & - & - & - \\
\hline Kategori & 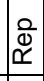 & $\frac{0}{\otimes}$ & $\begin{array}{l}\stackrel{0}{0} \\
\stackrel{x}{\alpha}\end{array}$ & \begin{tabular}{l}
0 \\
$\otimes$ \\
$\propto$ \\
\hdashline
\end{tabular} & 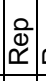 & $\begin{array}{l}\stackrel{2}{Q} \\
\check{\square}\end{array}$ & 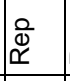 & $\begin{array}{l}\stackrel{0}{\alpha} \\
\alpha\end{array}$ & $\begin{array}{l}\stackrel{0}{0} \\
\stackrel{\alpha}{\alpha}\end{array}$ & $\stackrel{\varrho}{\ddot{\otimes}}$ & & 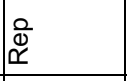 & $\begin{array}{l}\stackrel{0}{\otimes} \\
\propto\end{array}$ & $\begin{array}{l}\stackrel{0}{0} \\
\stackrel{\alpha}{\alpha}\end{array}$ \\
\hline 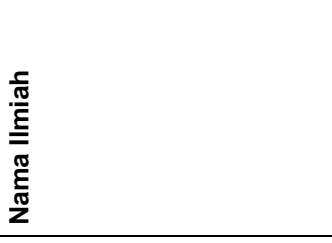 & 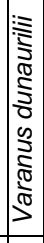 & 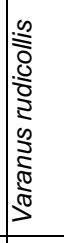 & 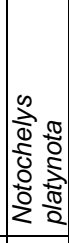 & 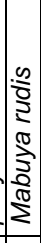 & 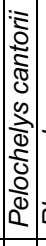 & 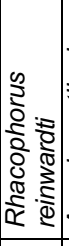 & 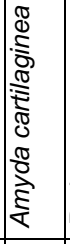 & $\begin{array}{l}0 \\
3 \\
5 \\
0 \\
0 \\
\delta \\
\vdots \\
\vdots \\
0 \\
0\end{array}$ & 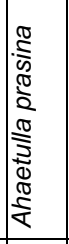 & 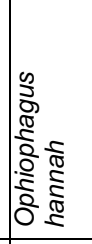 & 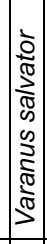 & 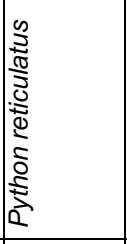 & $\bar{z}$ & 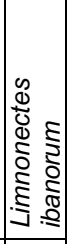 \\
\hline 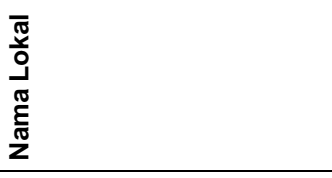 & 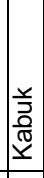 & 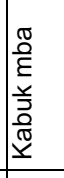 & $\frac{\frac{O}{0}}{\frac{0}{Q}}$ & 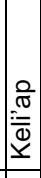 & 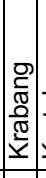 & 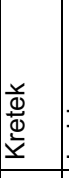 & बె & 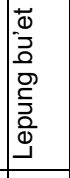 & 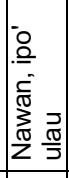 & 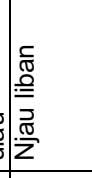 & & 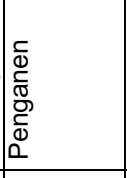 & & 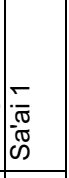 \\
\hline 을 & $\stackrel{10}{\sim}$ & 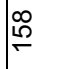 & $\stackrel{8}{\circ}$ & $\stackrel{0}{\circ}$ & $\div$ & $\dddot{\mho}$ & $\dddot{0}$ & $\stackrel{+}{\oplus}$ & 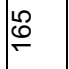 & 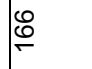 & & $\stackrel{\infty}{\cong}$ & $\stackrel{8}{\circ}$ & $\stackrel{R}{\gtrless}$ \\
\hline
\end{tabular}




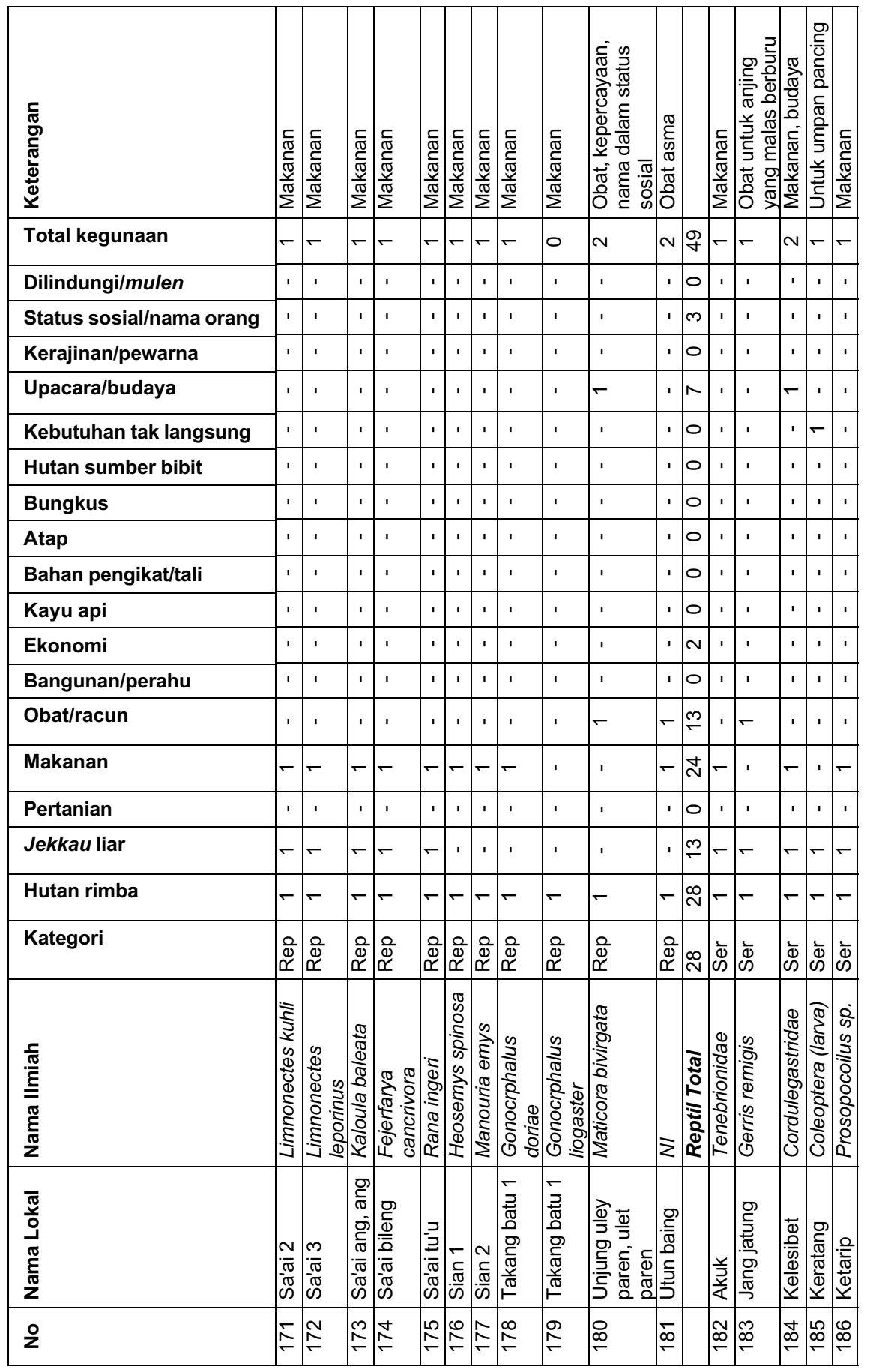




\begin{tabular}{|c|c|c|c|c|c|c|c|c|c|c|c|c|c|c|c|c|}
\hline 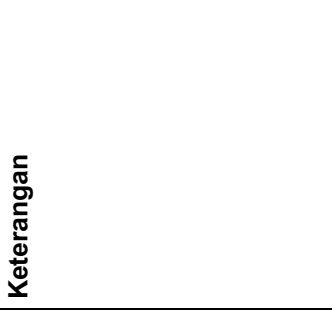 & 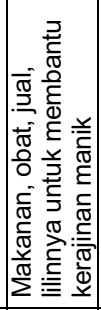 & 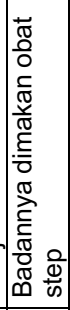 & 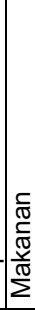 & 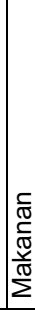 & 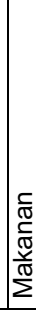 & $\begin{array}{l}- \\
+ \\
0 \\
0 \\
0\end{array}$ & 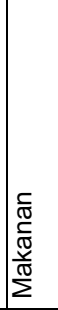 & 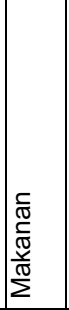 & 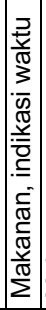 & \begin{tabular}{|l|} 
\\
\\
$\frac{c}{\pi}$ \\
$\frac{\pi}{\pi}$ \\
$\frac{2}{\pi}$ \\
$\frac{\pi}{2}$ \\
\end{tabular} & 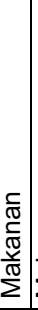 & & 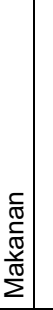 & 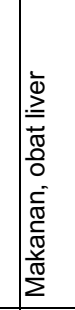 & & 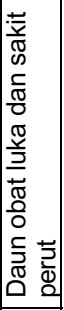 \\
\hline Total kegunaan & $\nabla$ & N & - & - & - & - & - & - & $\sim$ & - & - & $N$ & $-\leftarrow$ & $v)$ & $\sim$ & - \\
\hline Dilindungi/mulen & I & 1 & ' & 1 & 1 & 1 & 1 & ' & 1 & 1 & ! & 1 & 10 & ' & 0 & 1 \\
\hline Status sosial/nama orang & ' & ' & ' & ' & ' & 1 & 1 & ' & 1 & 1 & 1 & 1 & 10 & $\begin{array}{ll}1 \\
\end{array}$ & 0 & 1 \\
\hline Kerajinan/pewarna & - & 1 & ' & ' & ' & 1 & 1 & ' & 1 & 1 & 1 & 1 & \begin{tabular}{l|l} 
& -1 \\
1
\end{tabular} & -1 & 0 & I \\
\hline Upacara/budaya & ' & I & ' & ' & , & I & ' & , & ' & 1 & . & . & \begin{tabular}{l|l}
1 & \\
\end{tabular} & -1 & 0 & , \\
\hline Kebutuhan tak langsung & ' & 1 & ' & ' & 1 & 1 & 1 & ' & - & 1 & 1 & ' & . & v 1 & 0 & 1 \\
\hline Hutan sumber bibit & 1 & 1 & ' & ' & , & ' & 1 & ' & 1 & 1 & 1 & 1 & 10 & $\begin{array}{ll} \\
\end{array}$ & 0 & 1 \\
\hline Bungkus & ' & 1 & ' & ' & ' & 1 & 1 & ' & ' & 1 & ' & ' & 10 & $\begin{array}{ll}1 \\
\end{array}$ & 0 & 1 \\
\hline Atap & ' & ' & ' & ' & ' & 1 & 1 & ' & 1 & 1 & 1 & ' & 10 & D 1 & 0 & 1 \\
\hline Bahan pengikat/tali & ' & ' & ' & ' & ' & I & ' & ' & ' & 1 & 1 & ' & 10 & 1 & 0 & 1 \\
\hline Kayu api & ' & ' & ' & ' & ' & 1 & 1 & ' & ' & 1 & ' & 1 & 10 & $\begin{array}{ll} & 1\end{array}$ & 0 & 1 \\
\hline Ekonomi & - & 1 & ' & ' & ' & 1 & 1 & I & ' & 1 & ' & ' & \begin{tabular}{l|l}
1 & -1 \\
\end{tabular} & -1 & 0 & 1 \\
\hline Bangunan/perahu & ' & 1 & ' & ' & ' & 1 & 1 & 1 & ' & 1 & 1 & 1 & 10 & 1 & 0 & 1 \\
\hline Obat/racun & - & - & ' & 1 & 1 & - & 1 & ' & 1 & 1 & 1 & - & $1 / 5$ & 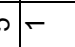 & - & - \\
\hline Makanan & - & - & - & - & - & 1 & - & - & - & - & - & - & -5 & 2 & - & 1 \\
\hline Pertanian & ' & ' & ' & 1 & 1 & 1 & 1 & ' & ' & 1 & ' & ' & 10 & $\begin{array}{ll}1 \\
\end{array}$ & 0 & 1 \\
\hline Jekkau liar & - & - & - & - & - & - & - & - & - & - & - & - & $-\infty$ & $0-$ & - & - \\
\hline Hutan rimba & - & - & - & . & . & - & - & ' & - & - & - & - & -5 & $2-$ & - & - \\
\hline Kategori & ¿্ঠ & $\begin{array}{l}\bar{\Phi} \\
\infty\end{array}$ & $\begin{array}{l}\grave{\Phi} \\
\omega\end{array}$ & $\begin{array}{l}\bar{\Phi} \\
\text { ஸे }\end{array}$ & ळे & ¿ & $\begin{array}{l}\bar{\Phi} \\
心\end{array}$ & ळ & \begin{tabular}{|c|}
$\bar{\Phi}$ \\
$心$
\end{tabular} & \begin{tabular}{|c|}
$\bar{\Phi}$ \\
$\infty$
\end{tabular} & $\begin{array}{l}\grave{\Phi} \\
\oplus\end{array}$ & $\begin{array}{l}\bar{\Phi} \\
\oplus\end{array}$ & $\stackrel{\grave{\Phi}}{\infty} \infty$ & $\circ \frac{0}{\infty}$ & - & $\underline{\xi}$ \\
\hline 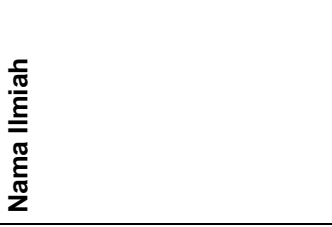 & 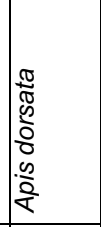 & 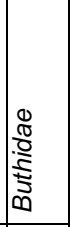 & 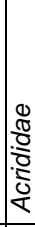 & 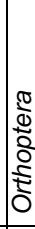 & 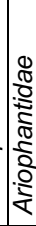 & 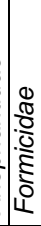 & 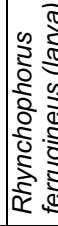 & 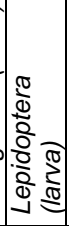 & $\begin{array}{l}0 \\
\frac{2}{2} \\
\frac{1}{d} \\
\stackrel{0}{2} \\
\frac{2}{2}\end{array}$ & 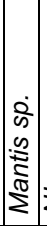 & $\Sigma$ & 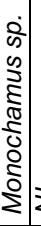 & 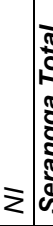 & 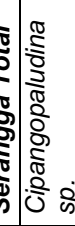 & 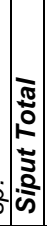 & 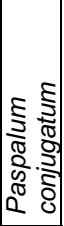 \\
\hline $\begin{array}{l}\bar{\pi} \\
\frac{\pi}{0} \\
\frac{1}{\pi} \\
\frac{\tilde{E}}{\pi} \\
\text { z }\end{array}$ & 旁 & 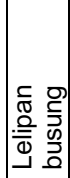 & ते & 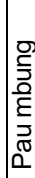 & 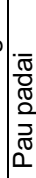 & $\begin{array}{l}\frac{E}{\pi} \\
\frac{\tilde{C}}{\mathbb{N}} \\
\tilde{N}\end{array}$ & $\vec{\oplus}$ & 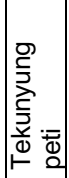 & 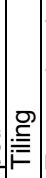 & 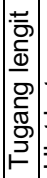 & 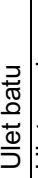 & 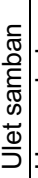 & 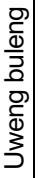 & 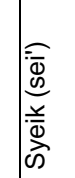 & & $\begin{array}{l}\frac{\pi}{0} \\
\frac{0}{0} \\
\frac{0}{10} \\
\frac{0}{10} \\
\frac{5}{3} \\
\frac{1}{4}\end{array}$ \\
\hline 울 & $\underset{\infty}{\infty}$ & 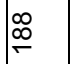 & $\stackrel{\infty}{-}$ & প & 함 & $\stackrel{\curvearrowright}{\curvearrowright}$ & סু & Ðே & $\stackrel{\text { L }}{\circ}$ & $\stackrel{\circ}{\circ}$ & مُ & $\stackrel{\infty}{\infty}$ & ஓ & 尽 & & $\bar{N}$ \\
\hline
\end{tabular}




\begin{tabular}{|c|c|c|c|c|c|c|c|c|c|c|c|c|c|c|c|}
\hline 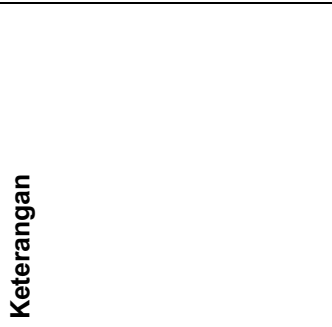 & 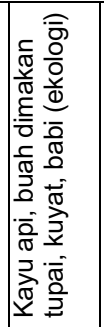 & 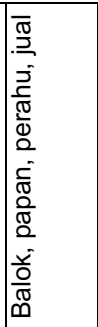 & 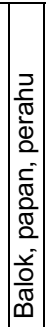 & 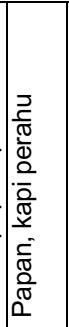 & 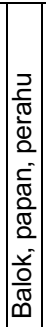 & 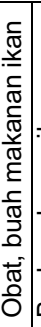 & 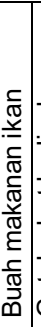 & 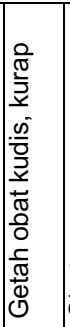 & 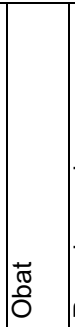 & 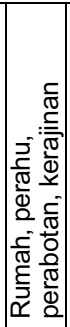 & 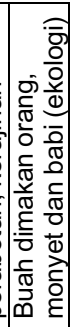 & 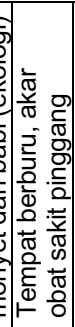 & 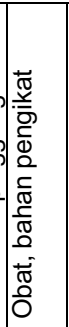 & & 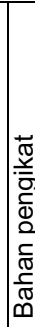 \\
\hline Total kegunaan & N & N & $N$ & N & $N$ & $\sim$ & $-c$ & N & - & $n$ & $m$ & N & N & - & F \\
\hline Dilindungi/mulen & ' & ' & 1 & 1 & 1 & . & . & | & ' & ' & ' & ' & ' & ' & ' \\
\hline Status sosial/nama orang & ' & ' & 1 & 1 & 1 & 1 & 1 & ' & ' & - & ' & ' & 1 & 1 & 1 \\
\hline Kerajinan/pewarna & ' & ' & 1 & 1 & 1 & 1 & 1 & 1 & 1 & - & ' & ' & 1 & 1 & 1 \\
\hline Upacara/budaya & ' & ' & 1 & ' & 1 & 1 & 1 & , & ' & - & ' & ' & ' & ' & ' \\
\hline Kebutuhan tak langsung & - & ' & 1 & 1 & 1 & - & - & - & 1 & ' & - & - & ' & 1 & ' \\
\hline Hutan sumber bibit & ' & ' & 1 & 1 & 1 & 1 & 1 & 1 & ' & ' & ' & ' & ' & 1 & 1 \\
\hline Bungkus & ' & ' & ' & 1 & ' & 1 & 1 & ' & 1 & ' & ' & ' & ' & 1 & I \\
\hline Atap & ' & ' & 1 & 1 & 1 & 1 & 1 & . & 1 & ' & ' & ' & ' & 1 & ' \\
\hline Bahan pengikat/tali & ' & ' & 1 & 1 & . & ' & 1 & 1 & 1 & ' & ' & ' & - & 1 & - \\
\hline Kayu api & - & ' & 1 & 1 & 1 & 1 & 1 & . & 1 & ' & - & ' & 1 & 1 & ' \\
\hline Ekonomi & ' & - & - & - & - & 1 & 1 & 1 & 1 & - & ' & ' & 1 & 1 & 1 \\
\hline Bangunan/perahu & ' & - & - & - & - & 1 & 1 & ' & 1 & - & ' & ' & 1 & 1 & ' \\
\hline Obat/racun & ' & ' & 1 & 1 & 1 & - & 1 & - & - & ' & ' & - & - & - & I \\
\hline Makanan & 1 & 1 & 1 & 1 & 1 & 1 & 1 & 1 & 1 & 1 & - & 1 & ' & 1 & ' \\
\hline Pertanian & ' & ' & 1 & 1 & ' & 1 & 1 & ' & ' & ' & ' & ' & ' & ' & ' \\
\hline Jekkau liar & ' & ' & 1 & 1 & 1 & - & - & - & I & - & ' & - & - & 1 & I \\
\hline Hutan rimba & - & - & - & - & - & - & - & - & - & - & - & 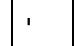 & - & - & $F$ \\
\hline Kategori & $\stackrel{\varepsilon}{\xi}$ & $\mid \underline{\xi}$ & $\frac{\varepsilon}{\xi}$ & $\underset{\vDash}{\xi}$ & $\frac{\varepsilon}{\Xi}$ & $\underset{\xi}{\Xi}$ & $\underset{\xi}{\Xi}$ & $\underline{\xi}$ & $\underline{\xi}$ & $\underset{\mathfrak{g}}{\mathfrak{F}}$ & $\underline{\xi}$ & $\frac{\varepsilon}{\xi}$ & $\underset{\xi}{\Xi}$ & $\frac{\varepsilon}{\underline{F}}$ & $\underline{\xi}$ \\
\hline 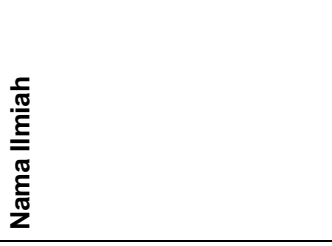 & 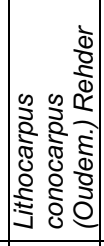 & 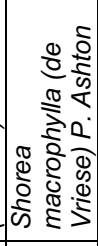 & 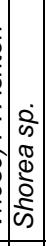 & 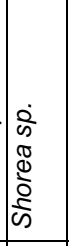 & 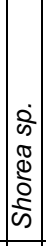 & 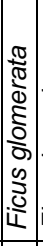 & 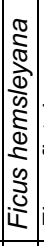 & 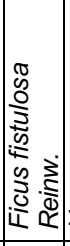 & 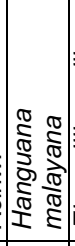 & 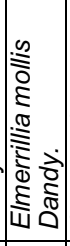 & 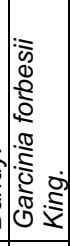 & 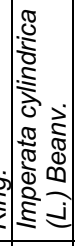 & 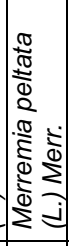 & & $\bar{z}$ \\
\hline $\begin{array}{l}\bar{\pi} \\
\frac{\pi}{0} \\
\frac{\pi}{\pi} \\
\frac{\pi}{\pi} \\
z\end{array}$ & 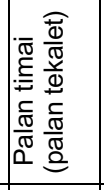 & 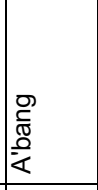 & 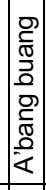 & 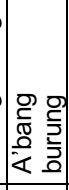 & 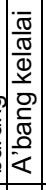 & 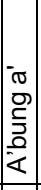 & 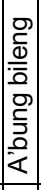 & 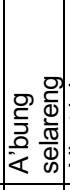 & $\begin{array}{l}\frac{0}{3} \\
\frac{3}{3} \\
\frac{3}{3} \\
\frac{0}{4} \\
\end{array}$ & $\begin{array}{l}0 \\
\frac{\pi}{0} \\
\frac{\pi}{2} \\
\end{array}$ & $\begin{array}{l} \\
\frac{3}{0} \\
\end{array}$ & 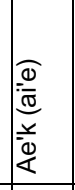 & 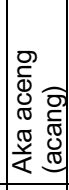 & 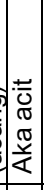 & $\begin{array}{l} \\
\\
\frac{\pi}{\pi} \\
\frac{\pi}{\pi} \\
\frac{\pi}{0} \\
\frac{3}{<}\end{array}$ \\
\hline 운 & ๙ิ & 垴 & & 尽 & 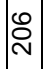 & & & 次 & $\frac{0}{i}$ & $\stackrel{\Sigma}{\sim}$ & $\stackrel{\aleph}{\sim}$ & $\frac{m}{N}$ & $\stackrel{ \pm}{\grave{N}}$ & $\stackrel{\infty}{\sim}$ & $\frac{\omega}{N}$ \\
\hline
\end{tabular}




\begin{tabular}{|c|c|c|c|c|c|c|c|c|c|c|c|c|c|c|c|c|c|}
\hline 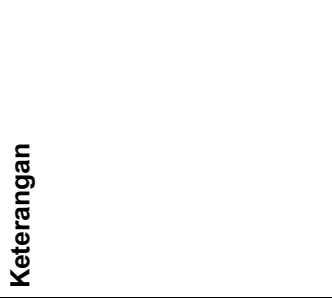 & 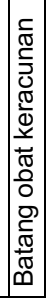 & 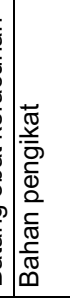 & 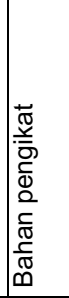 & 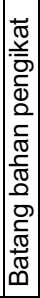 & 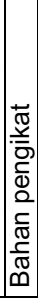 & 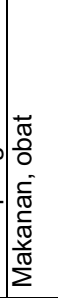 & 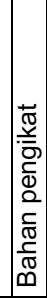 & $\begin{array}{l} \\
\mathbb{\pi} \\
\text { Oे } \\
\end{array}$ & \begin{tabular}{|l} 
\\
\\
$\vec{\sigma}$ \\
$\mathbb{0}$ \\
\end{tabular} & 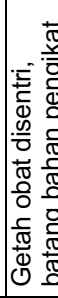 & 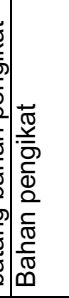 & \begin{tabular}{|l} 
\\
$\vec{\pi}$ \\
$\frac{\pi}{0}$ \\
\end{tabular} & 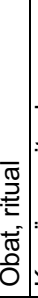 & 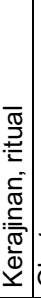 & $\begin{array}{l} \\
+\frac{\pi}{0} \\
0 \\
0\end{array}$ & 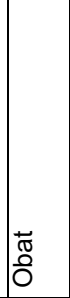 & 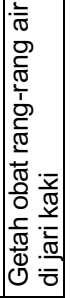 \\
\hline Total kegunaan & - & - & - & - & - & $\sim$ & - & - & - & $\sim$ & - & - & N & $\sim$ & - & - & 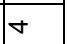 \\
\hline Dilindungi/mulen & ' & 1 & I & 1 & |' & 1 & ' & 1 & 1 & 1 & 1 & ' & ' & ' & ' & I & ' \\
\hline Status sosial/nama orang & 1 & 1 & ' & 1 & 1 & I & 1 & 1 & 1 & 1 & 1 & ' & ' & ' & 1 & 1 & ' \\
\hline Kerajinan/pewarna & 1 & 1 & 1 & 1 & 1 & 1 & 1 & 1 & 1 & 1 & 1 & 1 & ' & - & 1 & ' & ' \\
\hline Upacara/budaya & . & 1 & . & 1 & 1 & 1 & 1 & . & , & 1 & 1 & 1 & - & - & 1 & ' & ' \\
\hline Kebutuhan tak langsung & ' & 1 & 1 & 1 & 1 & ' & 1 & 1 & I & ' & ' & 1 & ' & ' & 1 & 1 & ' \\
\hline Hutan sumber bibit & ' & 1 & I & 1 & 1 & I & ' & ' & 1 & I & 1 & ' & ' & ' & 1 & ' & - \\
\hline Bungkus & 1 & ' & ' & 1 & 1 & 1 & 1 & 1 & 1 & 1 & 1 & ' & ' & ' & 1 & ' & ' \\
\hline Atap & 1 & 1 & 1 & 1 & 1 & 1 & ' & 1 & 1 & 1 & 1 & 1 & ' & ' & 1 & 1 & ' \\
\hline Bahan pengikat/tali & 1 & - & - & - & - & 1 & - & . & 1 & - & - & . & ' & ' & 1 & ' & I \\
\hline Kayu api & 1 & 1 & 1 & 1 & 1 & 1 & 1 & 1 & 1 & 1 & 1 & 1 & ' & ' & 1 & 1 & ' \\
\hline Ekonomi & 1 & 1 & 1 & 1 & 1 & 1 & ' & 1 & 1 & 1 & 1 & 1 & ' & ' & 1 & 1 & - \\
\hline Bangunan/perahu & 1 & 1 & 1 & 1 & 1 & 1 & 1 & 1 & 1 & 1 & 1 & . & ' & ' & 1 & 1 & ' \\
\hline Obat/racun & - & 1 & 1 & 1 & 1 & - & 1 & - & - & - & 1 & - & - & ' & - & - & - \\
\hline Makanan & 1 & 1 & 1 & 1 & 1 & - & 1 & 1 & 1 & 1 & 1 & 1 & ' & ' & 1 & ' & - \\
\hline Pertanian & 1 & 1 & 1 & 1 & 1 & 1 & 1 & 1 & 1 & 1 & 1 & ' & ' & ' & 1 & 1 & I \\
\hline Jekkau liar & 1 & 1 & 1 & 1 & 1 & - & - & 1 & 1 & 1 & 1 & - & ' & ' & $F$ & 1 & - \\
\hline Hutan rimba & - & - & - & - & - & - & - & - & - & - & - & - & - & - & 1 & - & - \\
\hline Kategori & $\frac{\xi}{3}$ & $\underset{1}{\xi}$ & $\underset{\vDash}{\xi}$ & $\mid \begin{array}{c}\xi \\
\sqsupseteq\end{array}$ & $\underset{f}{\underline{E}}$ & $\underset{\models}{\xi}$ & $\underset{\xi}{\xi}$ & $\underline{\underline{\xi}}$ & $\underset{\vDash}{\xi}$ & $\underset{F}{\xi}$ & $\underset{\xi}{\underline{\Xi}}$ & $\underset{\xi}{\underline{\xi}}$ & $\underline{\underline{\xi}}$ & $\underline{\xi}$ & $\frac{\xi}{\underline{F}}$ & $\underset{\vDash}{\xi}$ & $\underset{\xi}{\xi}$ \\
\hline 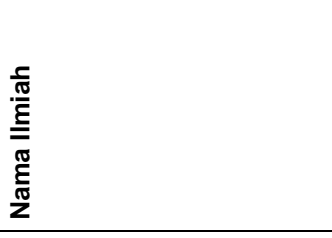 & $\bar{z}$ & 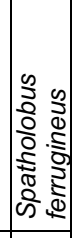 & 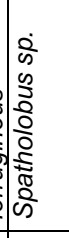 & 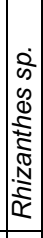 & $\bar{z}$ & 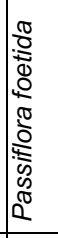 & $\bar{z}$ & 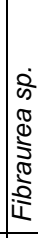 & 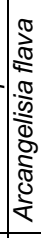 & 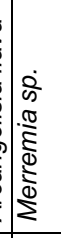 & $\bar{z}$ & 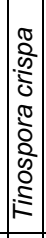 & & 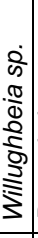 & 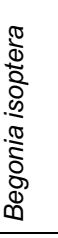 & 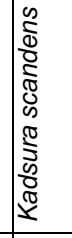 & 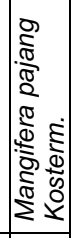 \\
\hline 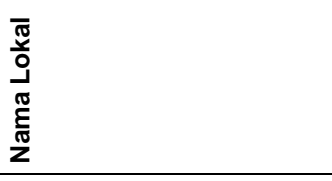 & 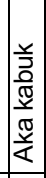 & 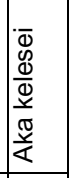 & 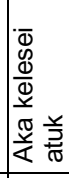 & 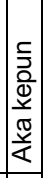 & 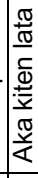 & 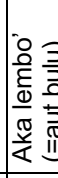 & 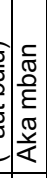 & 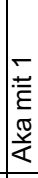 & 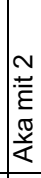 & 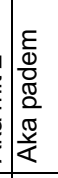 & 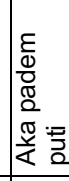 & 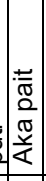 & 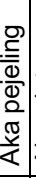 & 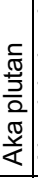 & 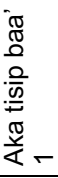 & 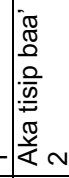 & $\frac{E}{\bar{\varepsilon}}$ \\
\hline$\stackrel{\circ}{z}$ & & $\stackrel{\infty}{\aleph}$ & $\frac{\Omega}{N}$ & & & స̃ & & & & 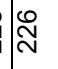 & $\hat{N}$ & $\stackrel{\infty}{\sim}$ & & & $\overline{\tilde{N}}$ & $\tilde{\widetilde{N}}$ & 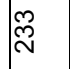 \\
\hline
\end{tabular}




\begin{tabular}{|c|c|c|c|c|c|c|c|c|c|c|c|c|c|}
\hline 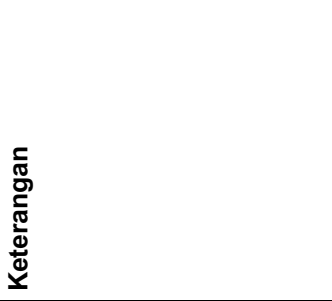 & 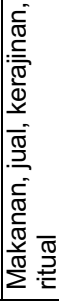 & 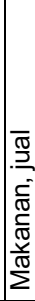 & \begin{tabular}{l} 
\\
\multirow{\pi}{*}{} \\
0 \\
0
\end{tabular} & 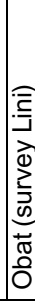 & 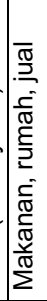 & 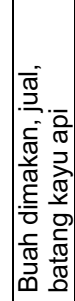 & $\frac{\mid}{\frac{\pi}{\widetilde{\sigma}}}$ & $\begin{array}{l}\overline{\tilde{N}} \\
\text { Oे }\end{array}$ & 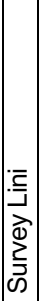 & 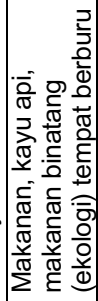 & 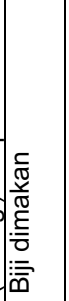 & 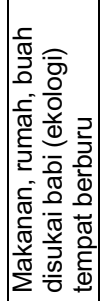 & 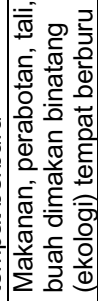 \\
\hline Total kegunaan & $\checkmark$ & N & - & - & t & $m$ & - & - & $r$ & $m$ & 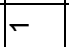 & t & t \\
\hline Dilindungi/mulen & ' & ' & ' & ' & 1 & ' & ' & ' & 1 & ' & ' & ' & ' \\
\hline Status sosial/nama orang & ' & ' & ' & 1 & 1 & ' & ' & ' & 1 & ' & ' & ' & ' \\
\hline Kerajinan/pewarna & - & ' & 1 & 1 & ' & ' & - & ' & ' & ' & ' & ' & - \\
\hline Upacara/budaya & - & , & , & , & , & , & ' & , & . & ' & , & ' & , \\
\hline Kebutuhan tak langsung & ' & ' & ' & 1 & 1 & 1 & ' & 1 & 1 & - & ' & - & - \\
\hline Hutan sumber bibit & ' & ' & ' & ' & - & ' & I & I & 1 & ' & ' & ' & ' \\
\hline Bungkus & ' & ' & ' & ' & 1 & 1 & ' & ' & 1 & 1 & ' & ' & ' \\
\hline Atap & 1 & ' & ' & 1 & 1 & ' & ' & 1 & ' & 1 & ' & ' & ' \\
\hline Bahan pengikat/tali & ' & ' & ' & 1 & 1 & ' & ' & ' & ' & 1 & ' & ' & - \\
\hline Kayu api & ' & ' & ' & 1 & 1 & - & ' & ' & 1 & - & ' & - & ' \\
\hline Ekonomi & - & - & ' & ' & - & - & I & 1 & ' & 1 & ' & ' & ' \\
\hline Bangunan/perahu & ' & ' & ' & ' & - & ' & ' & ' & 1 & 1 & ' & - & ' \\
\hline Obat/racun & ' & ' & - & F & I & ' & ' & - & , & ' & ' & 1 & ' \\
\hline Makanan & - & - & 1 & 1 & - & - & 1 & 1 & - & - & - & - & - \\
\hline Pertanian & - & - & 1 & I & - & ' & ' & 1 & 1 & ' & ' & ' & ' \\
\hline Jekkau liar & ' & ' & I & ' & - & 1 & - & 1 & 1 & 1 & ' & ' & - \\
\hline Hutan rimba & ' & ' & - & - & - & - & 1 & - & - & - & - & - & - \\
\hline Kategori & $\underline{\xi}$ & $\underline{\xi}$ & $\frac{\varepsilon}{F}$ & $\frac{\varepsilon}{F}$ & $\underset{\vDash}{\xi}$ & $\underset{F}{\xi}$ & $\underline{\xi}$ & $\underset{\vDash}{\varepsilon}$ & $\frac{\varepsilon}{\xi}$ & $\sum_{\vdash}^{\xi}$ & $\underset{\vdash}{\xi}$ & $\xi_{\vdash}^{\xi}$ & $\underline{\xi}$ \\
\hline $\begin{array}{l}\frac{c}{\frac{\pi}{\pi}} \\
\underline{\underline{E}} \\
\frac{\pi}{\tilde{n}} \\
\frac{\pi}{2}\end{array}$ & 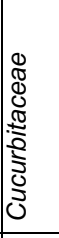 & $\begin{array}{l}0 \\
0 \\
0 \\
0 \\
\frac{1}{4} \\
0 \\
0 \\
0 \\
0\end{array}$ & 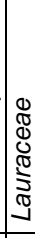 & $\bar{z}$ & 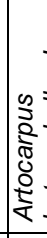 & 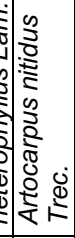 & 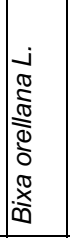 & 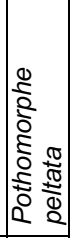 & & 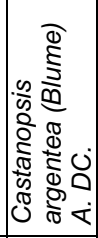 & 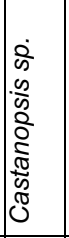 & 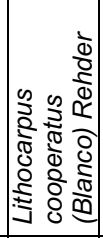 & 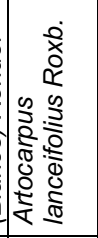 \\
\hline 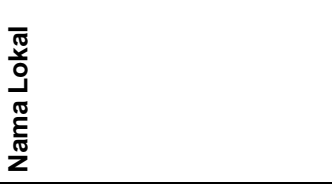 & $\begin{array}{l}\frac{c}{\sqrt{\sigma}} \\
\frac{E}{<}\end{array}$ & $\mid \begin{array}{l}0 \\
\frac{1}{8} \\
\frac{0}{\alpha}\end{array}$ & $\begin{array}{l}\overline{3} \\
\frac{2}{\pi} \\
\frac{0}{0} \\
\frac{0}{4}\end{array}$ & 离 & 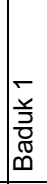 & 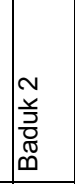 & 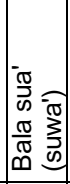 & 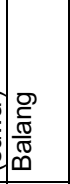 & & 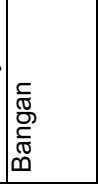 & 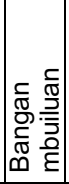 & 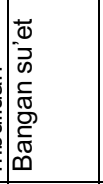 & 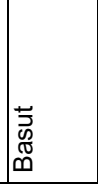 \\
\hline 울 & స్ & బొ & ల్ల & $\hat{\sim}$ & $\stackrel{\infty}{\sim}$ & శ్లి & 亲 & $\bar{\sim}$ & $\stackrel{\mathfrak{N}}{\sim}$ & 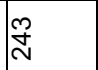 & 売 & $\stackrel{L}{\sim}$ & $\stackrel{O}{\stackrel{O}{\sim}}$ \\
\hline
\end{tabular}




\begin{tabular}{|c|c|c|c|c|c|c|c|c|c|c|c|c|c|}
\hline 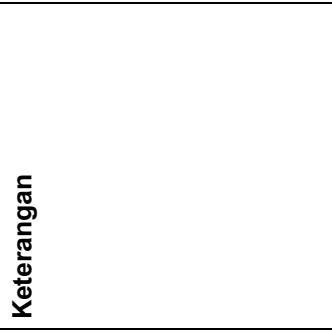 & 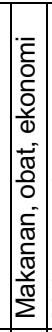 & 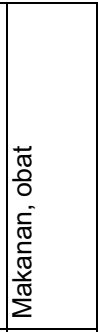 & 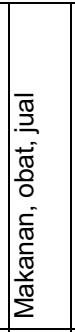 & 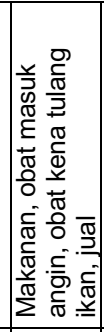 & 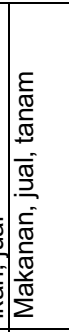 & 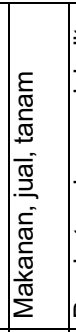 & 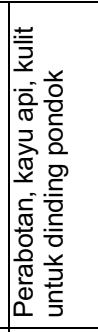 & 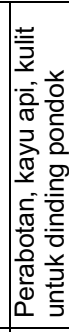 & 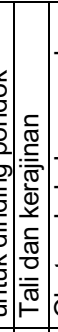 & 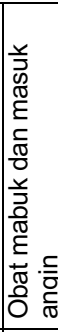 & 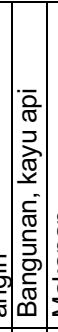 & 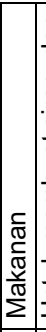 & 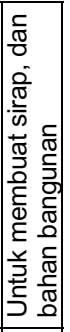 \\
\hline Total kegunaan & $m$ & N & $m$ & $m$ & $m$ & $m$ & $m$ & $m$ & $N$ & $m$ & $N$ & - & - \\
\hline Dilindungi/mulen & 1 & 1 & 1 & 1 & ' & ' & 1 & ' & ' & 1 & 1 & 1 & 1 \\
\hline Status sosial/nama orang & 1 & 1 & 1 & 1 & ' & ' & 1 & ' & 1 & ' & ' & 1 & 1 \\
\hline Kerajinan/pewarna & 1 & 1 & 1 & 1 & 1 & ' & - & - & - & ' & 1 & 1 & 1 \\
\hline Upacara/budaya & 1 & . & ' & ' & ' & ' & ' & ' & 1 & ' & ' & . & ' \\
\hline Kebutuhan tak langsung & 1 & 1 & 1 & ' & 1 & 1 & 1 & ' & 1 & 1 & ' & . & 1 \\
\hline Hutan sumber bibit & 1 & ' & 1 & ' & - & - & ' & ' & 1 & - & ' & 1 & ' \\
\hline Bungkus & 1 & . & ' & 1 & 1 & ' & 1 & ' & . & 1 & 1 & 1 & . \\
\hline Atap & . & 1 & ' & 1 & 1 & ' & 1 & ' & 1 & ' & ' & ' & ' \\
\hline Bahan pengikat/tali & 1 & ' & 1 & 1 & ' & 1 & 1 & ' & - & 1 & . & 1 & 1 \\
\hline Kayu api & 1 & 1 & 1 & ' & ' & 1 & - & - & 1 & ' & - & 1 & 1 \\
\hline Ekonomi & - & 1 & - & - & - & - & 1 & 1 & 1 & 1 & ' & 1 & 1 \\
\hline Bangunan/perahu & 1 & 1 & 1 & 1 & . & 1 & - & - & 1 & 1 & - & 1. & - \\
\hline Obat/racun & - & - & - & - & 1 & 1 & 1 & 1 & 1. & - & 1 & 1 & 1 \\
\hline Makanan & - & - & - & - & - & - & 1 & ' & 1, & - & 1. & - & ' \\
\hline Pertanian & - & 1 & - & 1 & 1 & 1 & 1 & ' & 1 & ' & 1 & 1 & 1 \\
\hline Jekkau liar & 1 & 1 & 1 & 1 & ' & 1 & ' & 1 & 1 & 1 & 1. & - & 1 \\
\hline Hutan rimba & 1 & 1 & 1 & 1 & - & - & - & - & 1 & - & - & 1 . & - \\
\hline Kategori & $\underset{\xi}{\xi}$ & $\xi$ & $\underline{\xi}$ & $\underset{F}{\xi}$ & $\underline{\xi}$ & $\underline{\xi}$ & $\xi_{\vdash}^{\xi}$ & $\underline{\varepsilon}$ & $\underset{f}{\xi}$ & $\underset{\xi}{\underline{\xi}}$ & $\underset{F}{\underline{F}}$ & $\underset{f}{\xi}$ & $\underset{\xi}{\xi}$ \\
\hline 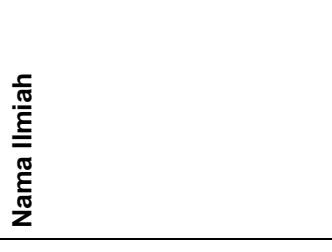 & 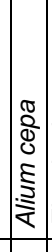 & 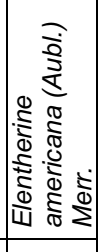 & 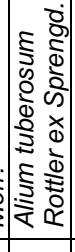 & :3. & 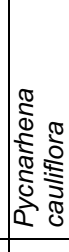 & 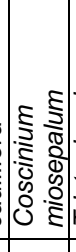 & 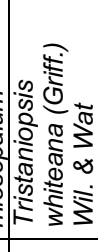 & 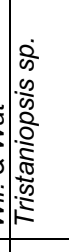 & 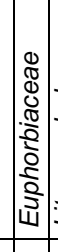 & 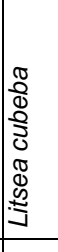 & 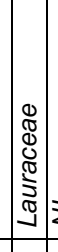 & & 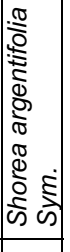 \\
\hline 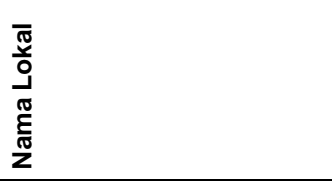 & 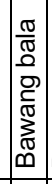 & 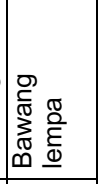 & 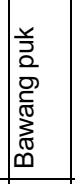 & 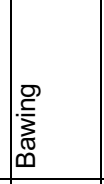 & 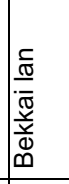 & 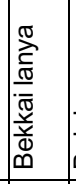 & 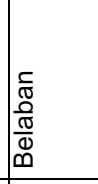 & 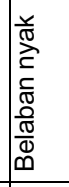 & 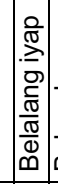 & \begin{tabular}{|l} 
\\
$\frac{\pi}{0}$ \\
$\frac{D}{0}$ \\
$\frac{\Phi}{0}$ \\
\end{tabular} & 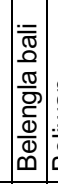 & 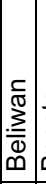 & 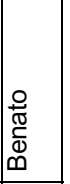 \\
\hline 운 & $\hat{d}$ & 倞 & 旅 & 怘 & $\overline{\mathfrak{N}}$ & బิ & $\stackrel{\infty}{\sim}$ & ڤે & م & 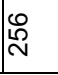 & $\hat{\mathfrak{N}}$ & $\begin{array}{l}\infty \\
\stackrel{\infty}{\infty} \\
\stackrel{2}{*}\end{array}$ & م̊ \\
\hline
\end{tabular}




\begin{tabular}{|c|c|c|c|c|c|c|c|c|c|c|c|c|}
\hline 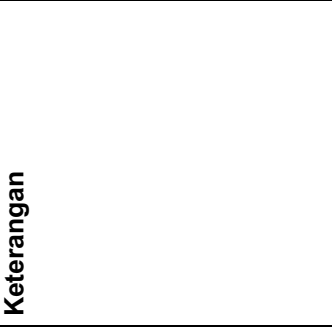 & 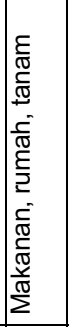 & 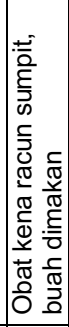 & 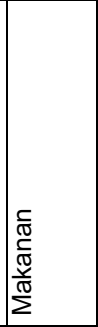 & 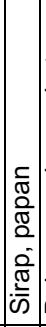 & 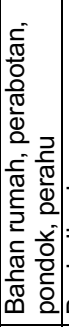 & 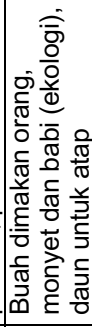 & 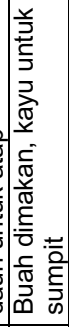 & 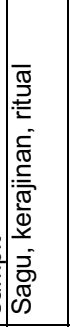 & 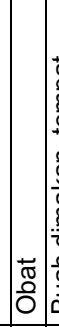 & 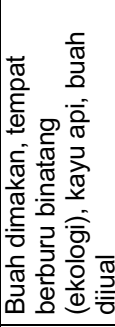 & 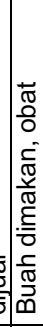 & 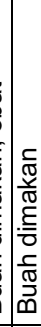 \\
\hline Total kegunaan & $m$ & 10 & - & $m$ & N & $\sim$ & N & $m$ & -6 & in & N & - \\
\hline Dilindungi/mulen & ' & - & ' & ' & 1 & ' & ' & ' & 1 . & $F$ & ' & ' \\
\hline Status sosial/nama orang & ' & 1 & ' & 1 & ' & ' & ' & ' & ' & ' & ' & ' \\
\hline Kerajinan/pewarna & ' & ' & ' & - & - & ' & - & - & ' & ' & ' & ' \\
\hline Upacara/budaya & ' & ' & ' & - & ' & ' & ' & - & ' & , & ' & , \\
\hline Kebutuhan tak langsung & ' & 1 & ' & $\cdot$ & 1 & ' & ' & ' & ' & 1 & ' & ' \\
\hline Hutan sumber bibit & - & - & ' & 1 & ' & ' & ' & ' & 1. & - & ' & ' \\
\hline Bungkus & ' & ' & ' & 1 & 1 & ' & ' & ' & ' & 1 & ' & ' \\
\hline Atap & ' & ' & ' & $\cdot$ & 1 & - & ' & ' & ' & 1 & ' & ' \\
\hline Bahan pengikat/tali & ' & ' & ' & ' & 1 & ' & ' & ' & ' & 1 & ' & ' \\
\hline Kayu api & ' & ' & ' & $\cdot$ & 1 & ' & ' & ' & 15 & - & ' & ' \\
\hline Ekonomi & ' & - & ' & ' & 1 & ' & ' & ' & 1. & - & ' & ' \\
\hline Bangunan/perahu & - & 1 & ' & - & - & ' & ' & ' & 1 & 1 & ' & ' \\
\hline Obat/racun & ' & - & ' & 1 & 1 & ' & ' & ' & - & ' & - & . \\
\hline Makanan & - & - & - & 1 & 1 & - & - & - & 15 & - & - & - \\
\hline Pertanian & - & - & - & 1 & 1 & ' & ' & ' & 1 & 1 & ' & ' \\
\hline Jekkau liar & ' & 1 & I & ' & 1 & - & - & ' & 1. & - & ' & ' \\
\hline Hutan rimba & - & - & 1 & - & - & - & - & - & -1 & - & F & - \\
\hline Kategori & $\sum_{\mathfrak{l}}^{\xi}$ & $\underset{\vDash}{\xi}$ & $\underset{\underline{\xi}}{\xi}$ & $\underset{\Xi}{\Xi}$ & $\underset{\underline{\xi}}{\underline{\underline{1}}}$ & $\underset{\models}{\xi}$ & $\xi_{\models}^{\xi}$ & $\underset{\vDash}{\models}$ & $\underset{F}{E}$ & $\underline{\xi}$ & & $\sum_{\models} \sqsupseteq$ \\
\hline $\begin{array}{l}\frac{c}{\frac{\pi}{E}} \\
\frac{\underline{E}}{\bar{\pi}} \\
\frac{\pi}{E} \\
\text { Z } \\
\end{array}$ & 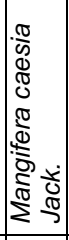 & 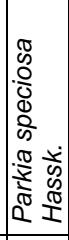 & 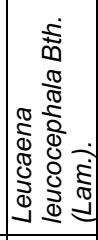 & 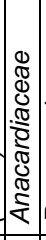 & 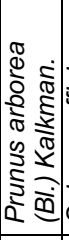 & 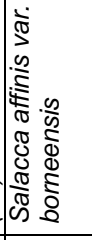 & 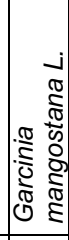 & \begin{tabular}{|l|}
0 \\
0 \\
$\frac{0}{2}$ \\
0 \\
0 \\
0 \\
0 \\
0 \\
0 \\
0 \\
0 \\
0 \\
0 \\
0 \\
0
\end{tabular} & 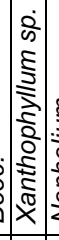 & 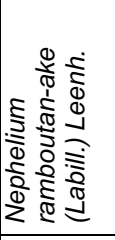 & 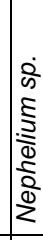 & 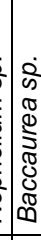 \\
\hline 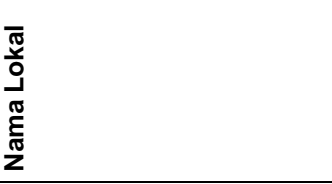 & 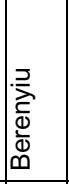 & 恋 & 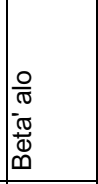 & $\left|\begin{array}{c}\bar{\varpi} \\
\frac{\pi}{\Phi} \\
\infty\end{array}\right|$ & \begin{tabular}{|l}
$\overline{\bar{\Phi}}$ \\
$\frac{ \pm}{\Phi}$ \\
$\infty$
\end{tabular} & : & 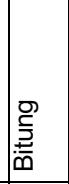 & \begin{tabular}{l}
0 \\
\hdashline \\
$\infty$ \\
$\infty$
\end{tabular} & $=$ & 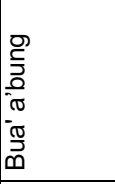 & & 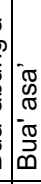 \\
\hline 울 & 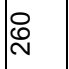 & $\overline{\stackrel{N}{N}}$ & స్ & 8 & స్ & 饹 & 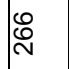 & $\hat{\mathscr{N}}$ & \begin{tabular}{l}
$\infty$ \\
$\vdots$ \\
\hdashline
\end{tabular} & 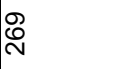 & $\stackrel{R}{N}$ & $\vec{v}$ \\
\hline
\end{tabular}




\begin{tabular}{|c|c|c|c|c|c|c|c|c|c|}
\hline 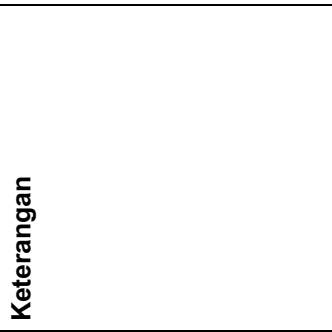 & 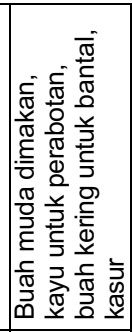 & 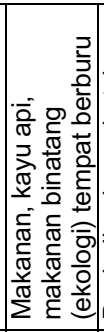 & 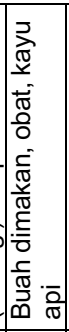 & 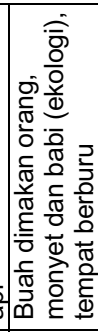 & 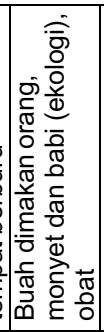 & 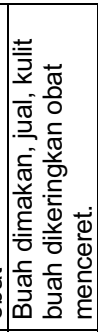 & 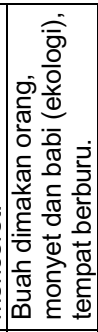 & 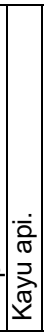 & 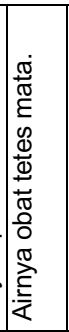 \\
\hline Total kegunaan & N & $m$ & $m$ & N & $m$ & $\infty$ & N & - & - \\
\hline Dilindungi/mulen & ' & ' & ' & 1 & 1 & - & ' & 1 & ' \\
\hline Status sosial/nama orang & ' & ' & ' & ' & ' & ' & ' & ' & I \\
\hline Kerajinan/pewarna & - & ' & ' & ' & ' & 1 & ' & ' & I \\
\hline Upacara/budaya & ' & ' & ' & ' & ' & ' & ' & 1 & ' \\
\hline Kebutuhan tak langsung & ' & - & 1 & - & - & ' & - & ' & ' \\
\hline Hutan sumber bibit & 1 & 1 & 1 & 1 & 1 & - & 1 & ' & 1 \\
\hline Bungkus & ' & ' & ' & ' & ' & 1 & ' & 1 & . \\
\hline Atap & ' & ' & 1 & 1 & ' & ' & ' & 1 & 1 \\
\hline Bahan pengikat/tali & ' & 1 & 1 & ' & ' & 1 & ' & 1 & 1 \\
\hline Kayu api & ' & - & - & 1 & ' & 1 & ' & - & . \\
\hline Ekonomi & 1 & 1 & 1 & 1 & 1 & - & 1 & 1 & 1 \\
\hline Bangunan/perahu & ' & ' & ' & ' & ' & ' & ' & 1 & . \\
\hline Obat/racun & ' & ' & - & ' & - & - & ' & ' & - \\
\hline Makanan & - & - & - & - & - & - & - & ' & ' \\
\hline Pertanian & - & ' & ' & ' & ' & 1 & ' & 1 & I \\
\hline Jekkau liar & 1 & 1 & 1 & 1 & ' & 1 & ' & 1 & 1 \\
\hline Hutan rimba & ' & - & - & - & - & - & - & - & - \\
\hline Kategori & $\underline{\xi}$ & $\underset{\Xi}{\Xi}$ & $\underset{\xi}{\xi}$ & $\underline{\xi}$ & $\underline{\xi}$ & $\underset{\mathfrak{F}}{\underline{\xi}}$ & $\underline{\xi}$ & $\underset{F}{\xi}$ & $\underset{\xi}{\xi}$ \\
\hline $\begin{array}{l}\frac{c}{\frac{\sigma}{\pi}} \\
\underline{\underline{\varepsilon}} \\
\frac{\pi}{\varepsilon} \\
\frac{\pi}{2} \\
\end{array}$ & 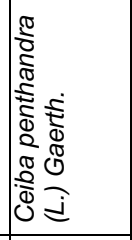 & 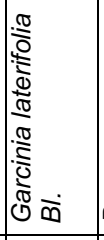 & 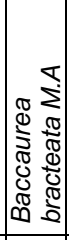 & 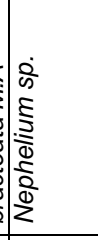 & 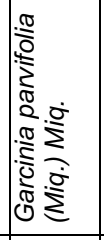 & 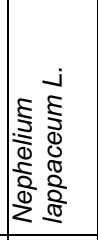 & 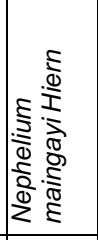 & 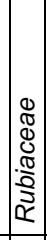 & 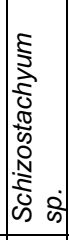 \\
\hline $\begin{array}{l}\bar{\pi} \\
\frac{\pi}{0} \\
\frac{\pi}{\pi} \\
\frac{\pi}{\pi} \\
z\end{array}$ & 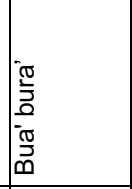 & 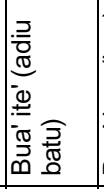 & 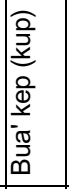 & 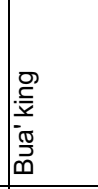 & 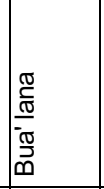 & 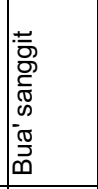 & 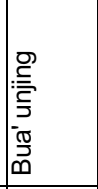 & 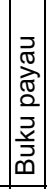 & 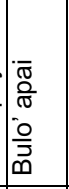 \\
\hline 운 & $\stackrel{N}{N}$ & $\stackrel{m}{N}$ & N & $\stackrel{\substack{n \\
\sim}}{\sim}$ & $\stackrel{\infty}{\stackrel{0}{N}}$ & $\hat{N}$ & $\stackrel{\infty}{\stackrel{\infty}{\sim}}$ & 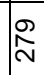 & $\stackrel{\infty}{\infty}$ \\
\hline
\end{tabular}




\begin{tabular}{|c|c|c|c|c|c|c|c|c|c|c|c|c|c|}
\hline 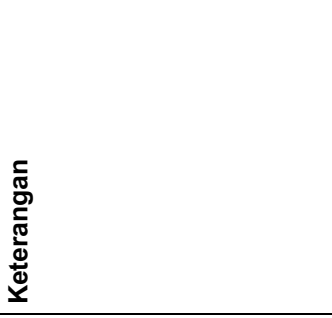 & 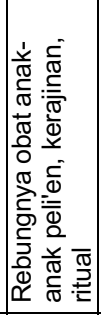 & 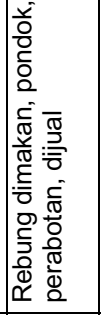 & 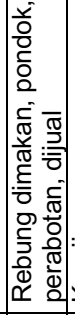 & 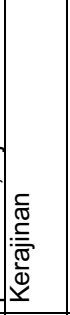 & 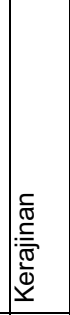 & 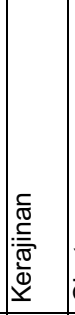 & \begin{tabular}{|l}
$\bar{\pi}$ \\
$\frac{\pi}{0}$
\end{tabular} & 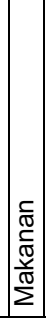 & 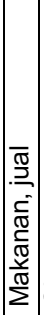 & $\begin{array}{l} \\
+\frac{\pi}{0} \\
\frac{0}{0}\end{array}$ & 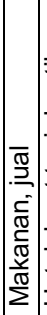 & 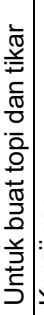 & 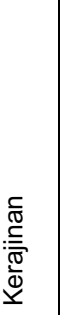 \\
\hline Total kegunaan & 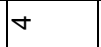 & $m$ & $m$ & N & - & - & - & N & N & N & $\sim$ & $m$. & - \\
\hline Dilindungi/mulen & ' & 1 & 1 & 1 & ' & ' & ' & ' & 1 & ' & 1 & ' & ' \\
\hline Status sosial/nama orang & ' & ' & ' & ' & ' & ' & ' & 1 & 1 & ' & $\cdot$ & 1 & ' \\
\hline Kerajinan/pewarna & - & - & - & - & - & - & ' & 1 & 1 & ' & 1 & - & - \\
\hline Upacara/budaya & - & 1 & ' & ' & ' & ' & ' & ' & 1 & ' & 1 & - & ' \\
\hline Kebutuhan tak langsung & ' & 1 & ' & 1 & ' & ' & ' & 1 & 1 & ' & $\cdot$ & 1 & 1 \\
\hline Hutan sumber bibit & ' & - & - & - & ' & ' & ' & 1 & 1 & ' & 1 & - & ' \\
\hline Bungkus & ' & ' & ' & ' & ' & ' & ' & 1 & 1 & ' & ' & 1 & ' \\
\hline Atap & ' & ' & ' & ' & ' & ' & ' & 1 & 1 & ' & $\cdot$ & 1 & 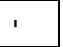 \\
\hline Bahan pengikat/tali & ' & ' & ' & ' & ' & ' & ' & ' & 1 & ' & 1 & 1 & ' \\
\hline Kayu api & ' & ' & ' & ' & ' & ' & ' & 1 & 1 & ' & 1 & ' & ' \\
\hline Ekonomi & ' & ' & ' & ' & ' & ' & ' & - & - & 1 & - & ' & ' \\
\hline Bangunan/perahu & ' & 1 & ' & 1 & ' & ' & ' & 1 & 1 & ' & $\cdot$ & 1 & ' \\
\hline Obat/racun & - & ' & ' & ' & ' & ' & - & ' & 1 & - & 1 & 1 & ' \\
\hline Makanan & - & - & - & 1 & 1 & 1 & 1 & - & - & - & - & 1 & 1 \\
\hline Pertanian & 1 & ' & ' & 1 & ' & ' & - & - & - & ' & - & 1 & 1 \\
\hline Jekkau liar & - & - & - & - & - & - & ' & 1 & 1 & ' & . & - & - \\
\hline Hutan rimba & - & - & - & - & - & - & ' & 1 & 1 & 1 & 1 & - & - \\
\hline Kategori & $\underset{\models}{\xi}$ & $\underset{\xi}{\underline{\xi}}$ & $\underset{\xi}{\xi}$ & $\underset{\xi}{\xi}$ & $\stackrel{\xi}{\xi}$ & $\underset{\vdash}{\xi}$ & $\underline{\xi}$ & $\underset{\models}{\underline{\xi}}$ & $\underset{\not}{\underline{E}}$ & $\underset{\models}{\xi}$ & $\underset{\xi}{\underline{\Xi}}$ & $\underset{\xi}{\xi}$ & $\underset{\vdash}{\xi}$ \\
\hline 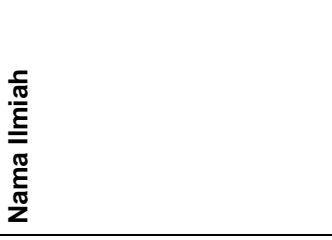 & 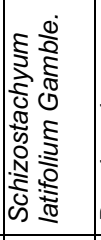 & 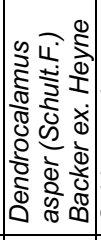 & 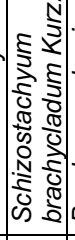 & 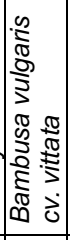 & 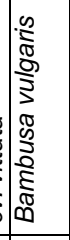 & 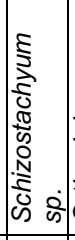 & 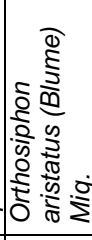 & 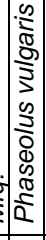 & 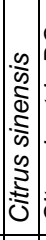 & 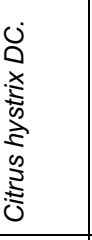 & $\mid \begin{array}{l}\frac{\pi}{2} \\
\frac{\pi}{3} \\
0 \\
0 \\
0 \\
0 \\
0 \\
0 \\
0 \\
0 \\
0\end{array}$ & 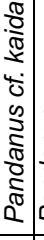 & 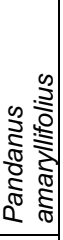 \\
\hline 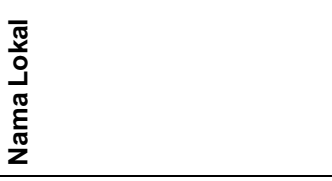 & \begin{tabular}{|l}
$\frac{}{\sigma}$ \\
$\frac{0}{0}$ \\
$\frac{0}{2}$ \\
$\infty$
\end{tabular} & 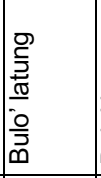 & 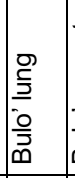 & 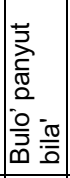 & 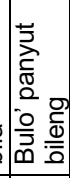 & 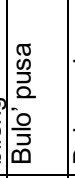 & 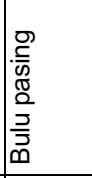 & 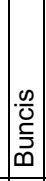 & 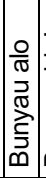 & 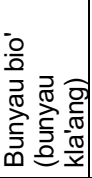 & 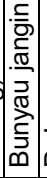 & . & $\begin{array}{l}\frac{0}{\pi} \\
\frac{\pi}{\pi} \\
\frac{\pi}{0}\end{array}$ \\
\hline zo & $\underset{\sim}{\infty}$ & $\widetilde{\mathscr{N}}$ & 位 & 敌 & $\stackrel{\infty}{\infty}$ & 怘 & $\hat{\infty}$ & $\begin{array}{l}\infty \\
\infty \\
\stackrel{\infty}{\infty}\end{array}$ & 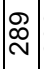 & ষ্ণ & $\overline{\mathscr{S}}$ & & న్ \\
\hline
\end{tabular}




\begin{tabular}{|c|c|c|c|c|c|c|c|c|c|c|c|c|}
\hline 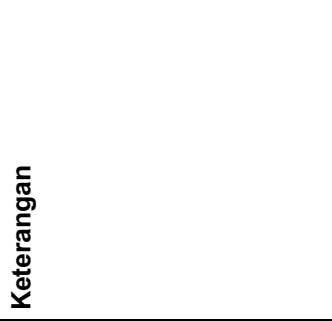 & 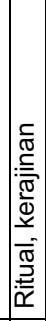 & 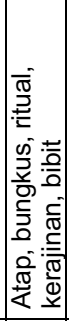 & 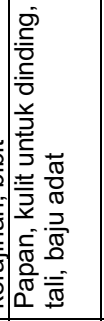 & 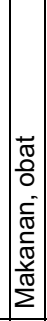 & 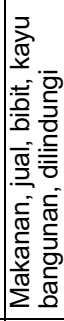 & 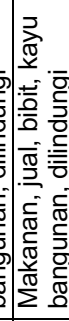 & 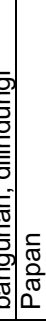 & \begin{tabular}{|l}
$\mid$ \\
$\frac{\pi}{\pi}$ \\
$\frac{2}{\pi}$ \\
0
\end{tabular} & 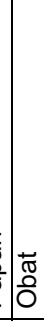 & 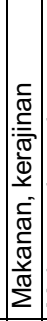 & 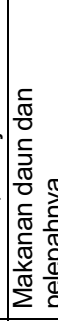 & 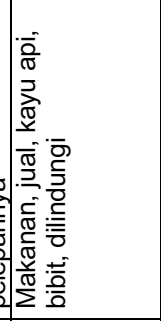 \\
\hline Total kegunaan & $m$ & 10 & t & N & is & is & - & - & - & $\sim$ & - & 10 \\
\hline Dilindungi/mulen & 1 & 1 & 1 & 1 & - & - & 1 & 1 & 1 & 1 & 1 & - \\
\hline Status sosial/nama orang & 1 & ' & ' & 1 & . & ' & ' & 1 & ' & ' & 1 & 1 \\
\hline Kerajinan/pewarna & - & - & - & 1 & 1 & 1 & 1 & 1 & 1 & - & 1 & 1 \\
\hline Upacara/budaya & - & - & - & 1 & . & ' & , & . & . & 1 & I & ' \\
\hline Kebutuhan tak langsung & 1 & 1 & I & 1 & 1 & 1 & ' & 1 & I & 1 & 1 & 1 \\
\hline Hutan sumber bibit & 1 & - & 1 & 1 & - & - & ' & 1 & 1 & 1 & 1 & - \\
\hline Bungkus & 1 & - & ' & 1 & . & ' & ' & I & I & 1 & 1 & ' \\
\hline Atap & 1 & - & ' & 1 & . & 1 & ' & 1 & 1 & 1 & 1 & ' \\
\hline Bahan pengikat/tali & 1 & 1 & - & 1 & . & ' & ' & 1 & 1 & 1 & 1 & 1 \\
\hline Kayu api & 1 & 1 & 1 & 1 & . & 1 & ' & 1 & I & 1 & 1 & - \\
\hline Ekonomi & - & 1 & 1 & 1 & - & - & ' & 1 & 1 & 1 & 1 & - \\
\hline Bangunan/perahu & 1 & I & - & 1 & - & - & - & - & 1 & 1 & 1 & 1 \\
\hline Obat/racun & 1 & ' & 1 & - & . & ' & ' & 1 & $F$ & 1 & 1 & 1 \\
\hline Makanan & 1 & 1 & ' & - & $F$ & $F$ & ' & 1 & 1 & - & $F$ & $F$ \\
\hline Pertanian & - & 1 & I & - & . & 1 & ' & 1 & 1 & 1 & 1 & 1 \\
\hline Jekkau liar & - & - & 1 & 1 & 1 & 1 & I & 1 & $F$ & 1 & - & 1 \\
\hline Hutan rimba & 1 & - & - & 1 & - & - & $F$ & - & 1 & - & - & - \\
\hline Kategori & $\underset{\vDash}{\xi}$ & $\underset{\models}{\underline{\xi}}$ & $\underset{\vdash}{\underline{\xi}}$ & $\frac{\varepsilon}{\xi}$ & $\underset{\models}{\xi}$ & $\underline{\xi}$ & $\underset{F}{\underline{F}}$ & $\int_{\vdash}$ & $\underset{\vdash}{\underline{F}}$ & $\frac{\varepsilon}{\xi}$ & $\underset{\risingdotseq}{\xi}$ & $\underset{\vdash}{\underline{\xi}}$ \\
\hline 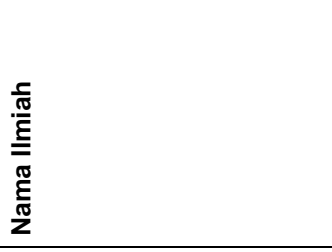 & 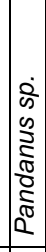 & 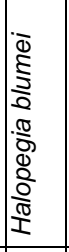 & 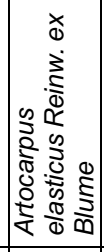 & 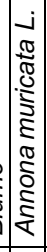 & 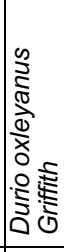 & 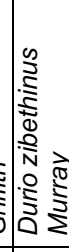 & 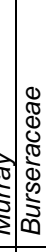 & 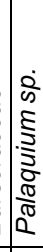 & 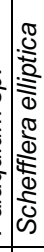 & 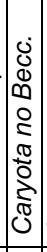 & 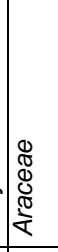 & 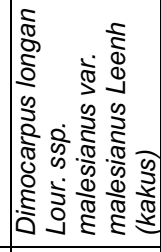 \\
\hline 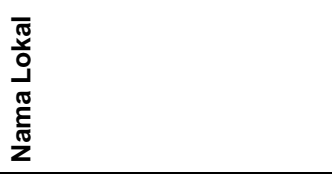 & 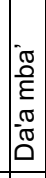 & $\overline{\frac{3}{\pi}}$ & 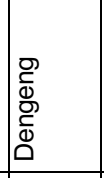 & 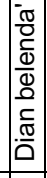 & 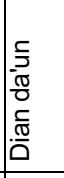 & 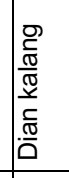 & $\underline{\underline{\underline{\sigma}}}$ & 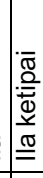 & 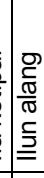 & $\begin{array}{l} \\
\underline{\underline{\tau}} \\
\underline{\underline{\Xi}} \\
\end{array}$ & 苛 & 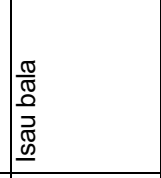 \\
\hline 운 & ষ্ণ & $\stackrel{2}{\stackrel{2}{2}}$ & 雨 & 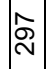 & $\stackrel{\infty}{\stackrel{\infty}{2}}$ & 尺্ & ৪্লি & & రิ & 㒸 & ষ্লি & గొల్లి \\
\hline
\end{tabular}




\begin{tabular}{|c|c|c|c|c|c|c|c|c|c|c|c|c|c|c|}
\hline 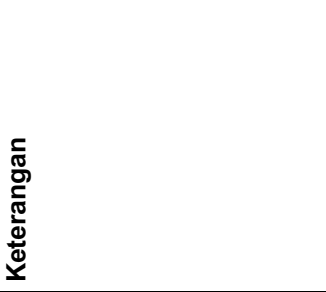 & 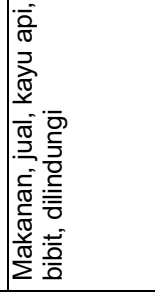 & 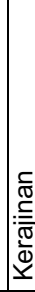 & 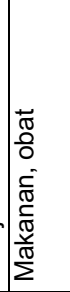 & 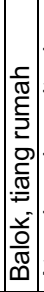 & 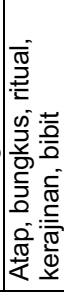 & 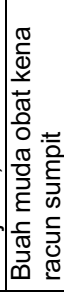 & 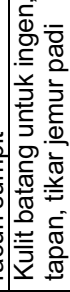 & 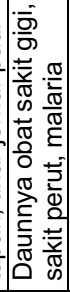 & 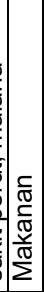 & 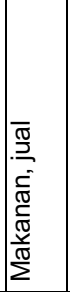 & 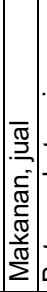 & & 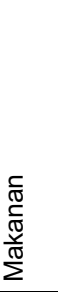 & 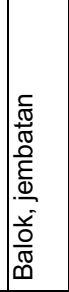 \\
\hline Total kegunaan & 10 & - & N & - & $\checkmark$ & N & - & N & - & N & $N$ & $-c$ & $\sim$ & - \\
\hline Dilindungi/mulen & - & ' & 1 & 1 & 1 & ' & ' & ' & ' & ' & ' & ' & ' & ' \\
\hline Status sosial/nama orang & 1 & ' & 1 & 1 & 1 & ' & ' & ' & ' & 1 & ' & ' & ' & ' \\
\hline Kerajinan/pewarna & 1 & - & 1 & 1 & - & 1 & - & ' & ' & 1 & ' & ' & ' & ' \\
\hline Upacara/budaya & ' & ' & . & 1. & - & ' & ' & ' & 1 & ' & ' & ' & ' & ' \\
\hline Kebutuhan tak langsung & 1 & I & 1 & 1 & 1 & ' & 1 & ' & 1 & ' & ' & ' & ' & ' \\
\hline Hutan sumber bibit & - & ' & 1 & 1 & 1 & ' & ' & ' & 1 & 1 & 1 & ' & ' & ' \\
\hline Bungkus & 1 & ' & 1 & 1 & - & ' & ' & ' & ' & 1 & ' & ' & ' & ' \\
\hline Atap & 1 & ' & 1 & 1 & - & ' & ' & ' & 1 & 1 & 1 & 1 & ' & ' \\
\hline Bahan pengikat/tali & 1 & ' & 1 & 1 & 1 & 1 & ' & ' & ' & 1 & 1 & ' & ' & ' \\
\hline Kayu api & - & I & 1 & 1 & I & ' & ' & ' & 1 & 1 & ' & ' & ' & 1 \\
\hline Ekonomi & - & I & 1 & 1 & I & ' & ' & ' & 1 & - & - & 1. & 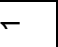 & 1 \\
\hline Bangunan/perahu & 1 & ' & 1 & - & 1 & ' & ' & ' & ' & I & ' & ' & ' & - \\
\hline Obat/racun & 1 & ' & - & ' & , & - & ' & - & ' & ' & 1 & $r$ & ' & ' \\
\hline Makanan & - & ' & - & 1 & 1 & - & 1 & - & - & - & - & 1. & - & ' \\
\hline Pertanian & ' & ' & - & 1 & I & - & 1 & 1 & ' & - & - & 1. & $r$ & 1 \\
\hline Jekkau liar & 1 & ' & 1 & 1 & - & 1 & 1 & - & ' & ' & 1 & ' & ' & 1 \\
\hline Hutan rimba & - & ' & 1 & - & - & 1 & - & 1 & - & 1 & 1 & - & ' & - \\
\hline Kategori & $\underset{\mathfrak{g}}{\xi}$ & $\underline{E}$ & $\underset{\xi}{\xi}$ & $\frac{\varepsilon}{F}$ & $\underset{\vDash}{\xi}$ & $\underline{\varepsilon}$ & $\underset{\xi}{\xi}$ & $\underline{\xi}$ & $\underline{\xi}$ & $\underset{\vdash}{\xi}$ & & 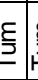 & $\underline{\xi}$ & $\underset{\xi}{\xi}$ \\
\hline 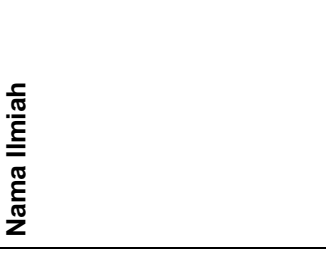 & 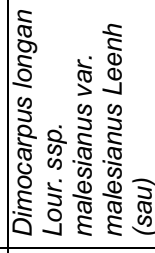 & 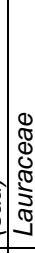 & 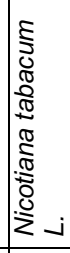 & 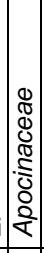 & 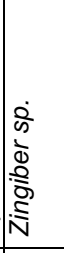 & 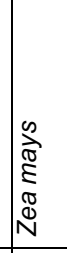 & 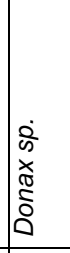 & 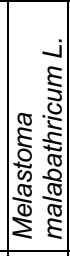 & & 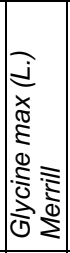 & 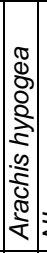 & 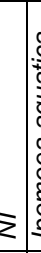 & 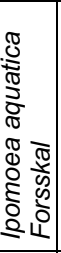 & 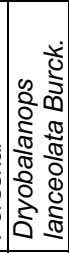 \\
\hline 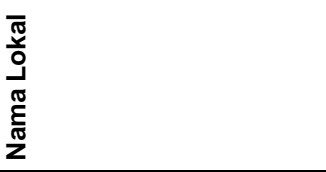 & 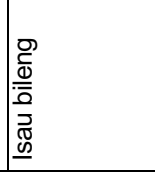 & $\underline{\underline{Q}}$ & 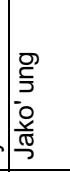 & 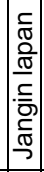 & 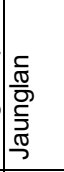 & $\frac{\bar{\pi}}{\stackrel{\omega}{\omega}}$ & 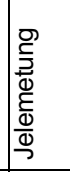 & 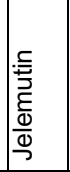 & $\begin{array}{l}\vec{g} \\
\frac{\bar{\sigma}}{\omega} \\
\frac{\omega}{\omega}\end{array}$ & 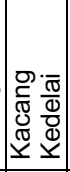 & 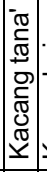 & & 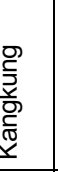 & 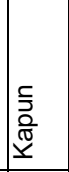 \\
\hline 운 & ஜ & & 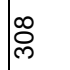 & 悹 & $\frac{0}{m}$ & $\frac{\Sigma}{m}$ & $\frac{N}{m}$ & $\frac{m}{m}$ & $\frac{\nabla}{m}$ & $\frac{10}{m}$ & $\frac{\infty}{m}$ & & $\frac{\infty}{m}$ & $\frac{\sigma}{m}$ \\
\hline
\end{tabular}




\begin{tabular}{|c|c|c|c|c|c|c|c|c|c|c|c|c|c|c|c|c|c|}
\hline 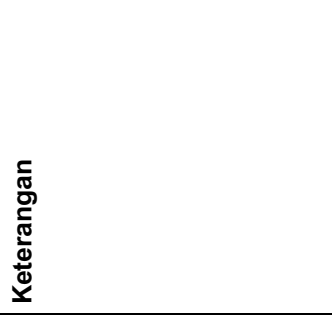 & 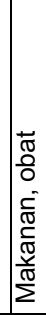 & $\frac{\bar{\alpha}}{\vec{\sigma}}$ & 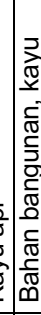 & 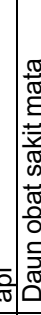 & 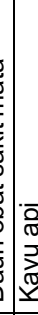 & 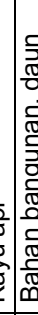 & 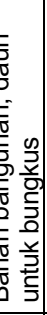 & 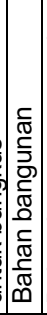 & 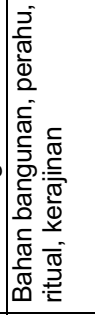 & \begin{tabular}{|c} 
\\
$\frac{0}{0}$ \\
$\frac{0}{0}$ \\
$\frac{0}{0}$ \\
$\frac{2}{0}$ \\
$\frac{\pi}{0}$ \\
0
\end{tabular} & 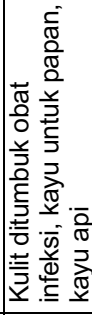 & 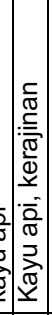 & 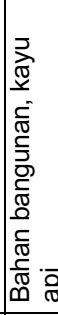 & 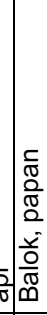 & 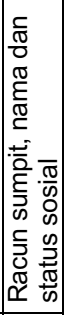 & 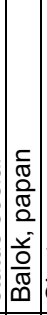 & \\
\hline Total kegunaan & N & - & N & $m$ & - & $-\alpha$ & $v$ & - & $m$ & - & $m$ & $\sim$ & N & - & $m$ & - & - \\
\hline Dilindungi/mulen & 1 & 1 & 1 & 1 & I & I & 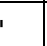 & 1 & 1 & 1 & ' & 1 & 1 & 1 & 1 & 1 & 1 \\
\hline Status sosial/nama orang & 1 & ' & ' & ' & 1 & 1 & & 1 & 1 & 1 & ' & 1 & 1 & 1 & - & ' & 1 \\
\hline Kerajinan/pewarna & ' & ' & 1 & F & 1 & 1 & & 1 & - & 1 & 1 & - & 1 & 1 & 1 & ' & 1 \\
\hline Upacara/budaya & ' & ' & ' & - & . & , & 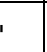 & . & - & ' & 1 & 1 & , & . & - & $\cdot$ & . \\
\hline Kebutuhan tak langsung & ' & ' & 1 & ' & 1 & 1 & & 1 & 1 & 1 & 1 & 1 & ' & 1 & 1 & 1 & 1 \\
\hline Hutan sumber bibit & ' & ' & ' & ' & ' & 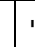 & & ' & 1 & 1 & ' & ' & 1 & 1 & ' & ' & 1 \\
\hline Bungkus & ' & ' & 1 & ' & I & -7 & & 1 & 1 & 1 & 1 & ' & 1 & 1 & 1 & 1 & 1 \\
\hline Atap & ' & ' & 1 & ' & . & i & & $\cdot$ & 1 & 1 & ' & $\cdot$ & ' & 1 & ' & $\cdot$ & 1 \\
\hline Bahan pengikat/tali & ' & ' & I & ' & ' & . & & 1 & 1 & 1 & ' & 1 & 1 & 1 & ' & 1 & 1 \\
\hline Kayu api & 1 & - & - & ' & - & 1 & & 1 & 1 & 1 & - & - & - & 1 & ' & 1 & 1 \\
\hline Ekonomi & ' & 1 & 1 & ' & . & . & & ' & 1 & 1 & 1 & 1 & 1 & 1 & 1 & 1 & 1 \\
\hline Bangunan/perahu & ' & ' & - & ' & I & 7 & & - & - & - & - & ' & - & - & 1 & - & 1 \\
\hline Obat/racun & - & ' & ' & - & 1 & , & & 1 & 1 & 1 & - & ' & i & 1 & - & 1 & - \\
\hline Makanan & - & ' & ' & ' & ' & 1 & & $\cdot$ & ' & 1 & ' & 1 & ' & . & ' & 1 & 1 \\
\hline Pertanian & 1 & ' & I & ' & 1 & 1 & & ' & I & 1 & I & 1 & I & 1 & ' & 1 & 1 \\
\hline Jekkau liar & 1 & 1 & 1 & ' & 1 & , & & ! & 1 & - & - & - & 1 & 1 & I & 1 & - \\
\hline Hutan rimba & - & $F$ & - & - & - & -7 & & - & - & - & - & - & - & $F$ & - & - & - \\
\hline Kategori & $\sum_{\models}^{\xi}$ & $\underset{\xi}{\xi}$ & ${ }_{1 F}$ & $\underline{\xi}$ & $\frac{\varepsilon}{F}$ & 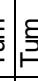 & & $\underset{f}{\underline{\Xi}}$ & $\underline{\xi}$ & $\underset{\xi}{\xi}$ & $\underset{\xi}{\underline{\xi}}$ & $\underset{\xi}{\underline{\xi}}$ & $\underset{\vdash}{\underline{\xi}}$ & $\underset{\xi}{\xi}$ & $\underset{\underline{F}}{\xi}$ & $\frac{\xi}{\xi} \mid$ & $\underset{\mathfrak{F}}{\underline{\xi}}$ \\
\hline 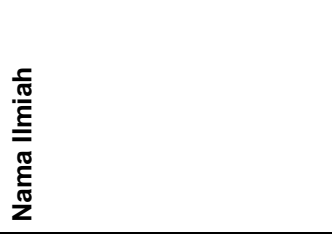 & 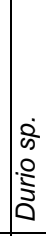 & \begin{tabular}{l}
$\mathbb{8}$ \\
$\mathbb{8}$ \\
$\mathbb{8}$ \\
$\mathbb{8}$ \\
\multirow{5}{5}{} \\
$\Sigma$
\end{tabular} & 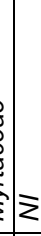 & $\bar{z}$ & 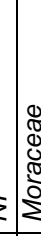 & לִ. & & & 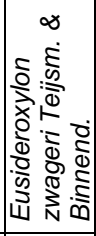 & & 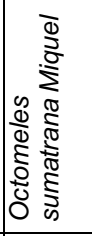 & 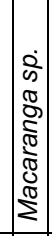 & $\Sigma$ & $\bar{z}$ & 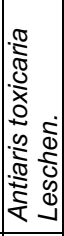 & $\frac{1}{2}$ & 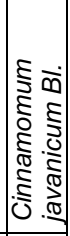 \\
\hline 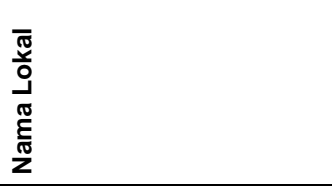 & $\begin{array}{l}\tilde{\pi} \\
\frac{\pi}{\pi} \\
\underline{\pi}\end{array}$ & 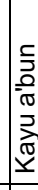 & 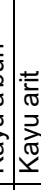 & 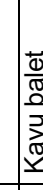 & 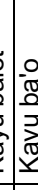 & 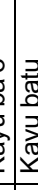 & & 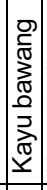 & 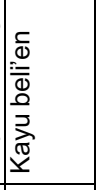 & 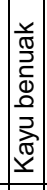 & 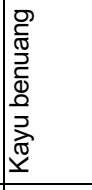 & 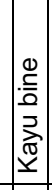 & 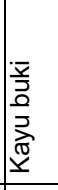 & 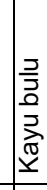 & 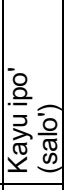 & 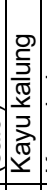 & 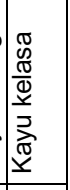 \\
\hline 운 & స్ల & & N & స్ల & ș & v. & & $\begin{array}{l}\mathscr{N} \\
\tilde{m}\end{array}$ & స్ & $\begin{array}{l}\infty \\
\tilde{m}\end{array}$ & స్ & & ল্ল & స్ల్ల & ల్లె & & $\stackrel{m}{\infty}$ \\
\hline
\end{tabular}




\begin{tabular}{|c|c|c|c|c|c|c|c|c|c|c|c|c|c|c|c|}
\hline 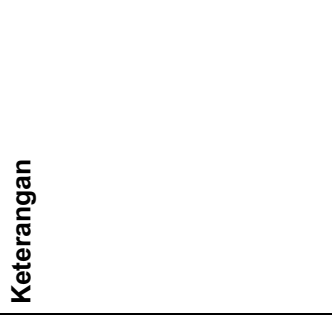 & 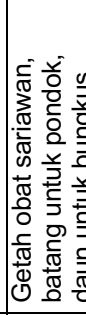 & 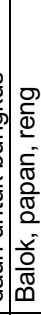 & 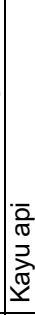 & 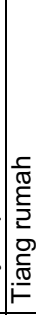 & 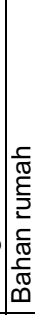 & 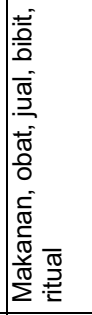 & 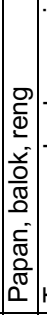 & 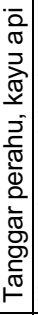 & 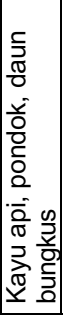 & 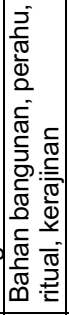 & 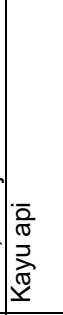 & 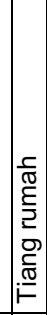 & 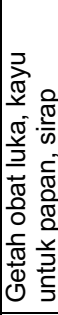 & 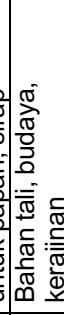 & 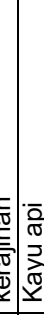 \\
\hline Total kegunaan & $m$ & - & - & - & - & 10 & - & $N$ & $m$ & - & - & - & $m$ & $m$ & - \\
\hline Dilindungi/mulen & 1 & ' & 1 & 1 & 1 & 1 & 1 & 1 & 1 & 1 & ' & 1 & 1 & 1 & ' \\
\hline Status sosial/nama orang & 1 & ' & 1 & ' & 1 & 1 & 1 & 1 & 1 & ' & ' & 1 & 1 & 1 & ' \\
\hline Kerajinan/pewarna & ' & 1 & 1 & ' & 1 & 1 & $\cdot$ & 1 & 1 & 1 & 1 & 1 & 1 & - & ' \\
\hline Upacara/budaya & - & ' & . & ' & . & - & . & 1 & . & ' & ' & 1 & , & - & , \\
\hline Kebutuhan tak langsung & 1 & ' & 1 & ' & 1 & 1 & $\cdot$ & 1 & 1 & 1 & 1 & 1 & 1 & 1 & ' \\
\hline Hutan sumber bibit & 1 & 1 & ' & ' & 1 & - & ' & ' & 1 & 1 & ' & 1 & I & ' & ' \\
\hline Bungkus & - & ' & 1 & ' & 1 & 1 & 1 & 1 & - & ' & 1 & 1 & 1 & ' & 1 \\
\hline Atap & 1 & ' & 1 & ' & 1 & ' & 1 & 1 & 1 & 1 & ' & 1 & 1 & 1 & ' \\
\hline Bahan pengikat/tali & 1 & ' & 1 & ' & 1 & 1 & 1 & 1 & 1 & 1 & 1 & 1 & 1 & - & ' \\
\hline Kayu api & ' & 1 & - & ' & 1 & 1 & 1 & - & - & 1 & - & 1 & - & 1 & - \\
\hline Ekonomi & 1 & 1 & 1 & ' & 1 & - & 1 & 1 & 1 & 1 & 1 & 1 & 1 & 1 & ' \\
\hline Bangunan/perahu & ' & - & 1 & - & - & 1 & - & - & - & - & 1 & - & - & 1 & I \\
\hline Obat/racun & - & ' & . & 1 & 1 & - & 1 & 1 & 1 & 1 & 1 & 1 & - & 1 & ' \\
\hline Makanan & 1 & ' & . & 1 & 1 & - & 1 & 1 & 1 & 1 & 1 & 1 & 1 & 1 & ' \\
\hline Pertanian & ' & ' & 1 & 1 & 1 & 1 & 1 & 1 & 1 & 1 & 1 & 1 & 1 & 1 & ' \\
\hline Jekkau liar & - & 1 & ' & ' & 1 & 1 & 1 & 1 & - & 1 & 1 & 1 & 1 & 1 & ' \\
\hline Hutan rimba & - & - & - & F & - & - & - & - & - & - & - & - & - & - & F \\
\hline Kategori & $\frac{\xi}{\xi}$ & $\underline{\xi}$ & $\underset{f}{\xi}$ & $\underline{\xi}$ & $\underset{F}{\underline{F}}$ & $\stackrel{\xi}{\xi}$ & $\underset{\xi}{\underline{\xi}}$ & $\underset{\xi}{\Xi}$ & $\underset{\models}{\underline{F}}$ & 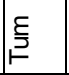 & $\underset{\vdash}{\underline{\xi}}$ & $\underset{F}{\underline{\Xi}}$ & $\frac{\xi}{F}$ & $\underset{\risingdotseq}{\underline{\xi}}$ & $\underset{\xi}{\xi}$ \\
\hline 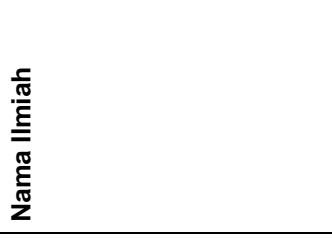 & 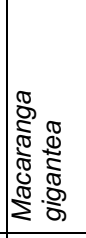 & $\bar{z}$ & $\bar{z}$ & 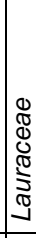 & 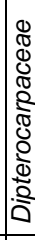 & 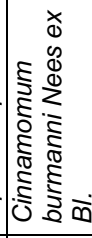 & 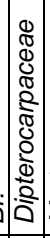 & 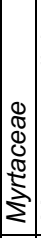 & 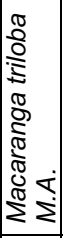 & 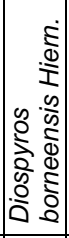 & 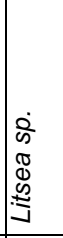 & $\bar{z}$ & $\bar{z}$ & 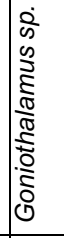 & $\bar{z}$ \\
\hline 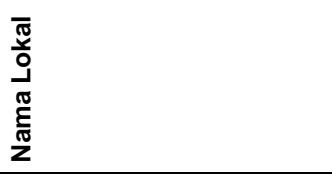 & 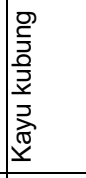 & 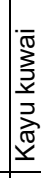 & 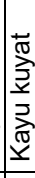 & 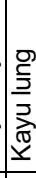 & 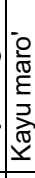 & 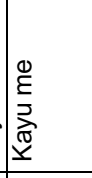 & 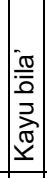 & 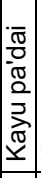 & 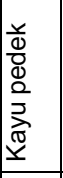 & 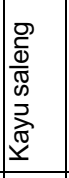 & 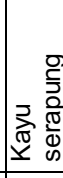 & 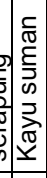 & $\frac{\pi}{\stackrel{\pi}{\pi}}$ & & 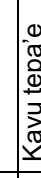 \\
\hline 운 & 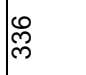 & $\hat{m}$ & 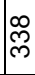 & প্ল & 吕 & 更 & ले & $\stackrel{m}{q}$ & 离 & 卢 & 过 & 全 & 悉 & लि & 율 \\
\hline
\end{tabular}




\begin{tabular}{|c|c|c|c|c|c|c|c|c|c|c|c|c|c|}
\hline 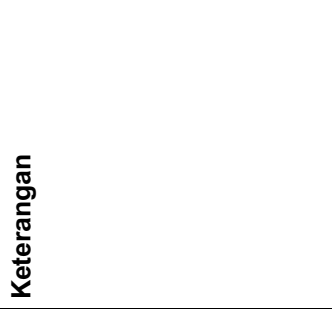 & 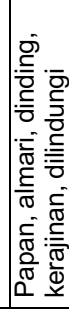 & 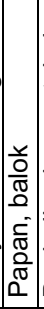 & 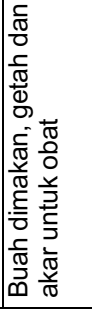 & 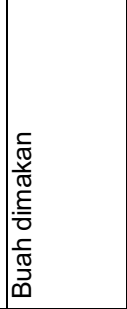 & 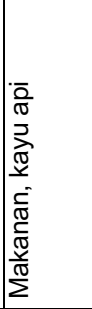 & 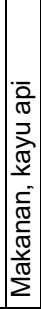 & 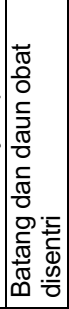 & $\begin{array}{l} \\
\\
\frac{c}{0} \\
\frac{\pi}{\pi} \\
0 \\
0\end{array}$ & 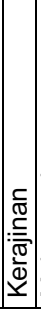 & 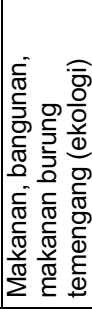 & 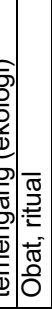 & 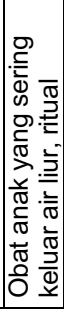 & 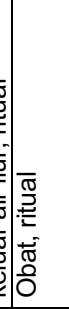 \\
\hline Total kegunaan & $m$ & N & $\sim$ & - & N & N & - & $m$ & - & $m$ & N & N & N \\
\hline Dilindungi/mulen & - & 1 & 1 & 1 & 1 & 1 & 1 & ' & 1 & 1 & ' & ' & ' \\
\hline Status sosial/nama orang & 1 & ' & I & ' & ' & 1 & 1 & ' & 1 & 1 & 1 & ' & 1 \\
\hline Kerajinan/pewarna & - & ' & 1 & 1 & 1 & 1 & 1 & 1 & - & 1 & 1 & ' & 1 \\
\hline Upacara/budaya & ' & $\cdot$ & , & ' & ' & , & , & ' & 1 & 1 & - & - & - \\
\hline Kebutuhan tak langsung & ' & 1 & 1 & 1 & 1 & 1 & 1 & 1 & 1 & - & 1 & ' & ' \\
\hline Hutan sumber bibit & ' & 1 & I & ' & ' & 1 & ' & ' & 1 & ' & 1 & ' & ' \\
\hline Bungkus & ' & ' & 1 & ' & ' & 1 & 1 & 1 & 1 & 1 & 1 & ' & ' \\
\hline Atap & ' & $\cdot$ & 1 & 1 & 1 & 1 & 1 & - & 1 & 1 & ' & ' & ' \\
\hline Bahan pengikat/tali & ' & 1 & ' & ' & ' & 1 & . & - & 1 & 1 & 1 & ' & ' \\
\hline Kayu api & ' & - & 1 & ' & - & - & 1 & 1 & 1 & 1 & 1 & ' & ' \\
\hline Ekonomi & ' & 1 & I & 1 & 1 & 1 & 1 & 1 & 1 & 1 & 1 & ' & ' \\
\hline Bangunan/perahu & - & - & ' & 1 & 1 & 1 & 1 & - & 1. & - & 1 & ' & ' \\
\hline Obat/racun & ' & 1 & - & 1 & 1 & 1 & - & ' & 1 & 1 & - & - & - \\
\hline Makanan & ' & 1 & - & - & - & - & 1 & 1 & 1 & - & 1 & ' & ' \\
\hline Pertanian & ' & 1 & 1 & 1 & 1 & 1 & 1 & 1 & 1 & 1 & 1 & - & 1 \\
\hline Jekkau liar & ' & 1 & ' & 1 & - & 1 & 1 & 1 & 1 & 1 & 1 & ' & 1 \\
\hline Hutan rimba & - & - & - & - & - & - & - & - & 1 & - & - & 1 & - \\
\hline Kategori & $\xi_{\vdash}^{\xi}$ & $\frac{\varepsilon}{\xi}$ & $\underline{\varepsilon}$ & $\underset{\vDash}{\varepsilon}$ & $\underline{\xi}$ & $\underset{\models}{\xi}$ & $\underset{\vDash}{\xi}$ & $\sum_{\vDash}^{\xi}$ & $\frac{\xi}{F}$ & $\underline{\xi}$ & $\frac{\xi}{\vDash}$ & $\underline{\xi}$ & $\underset{\vDash}{\xi}$ \\
\hline 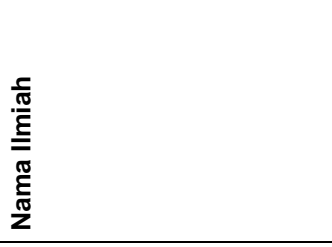 & 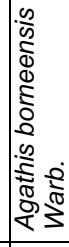 & 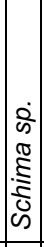 & 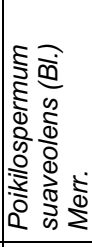 & 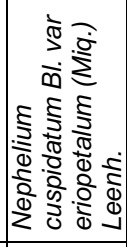 & 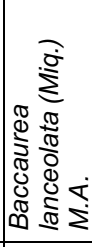 & 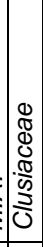 & $\bar{z}$ & $\bar{z}$ & $\bar{z}$ & 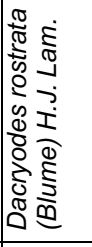 & 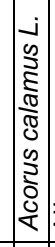 & & 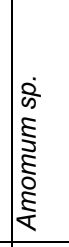 \\
\hline $\begin{array}{l}\bar{\sigma} \\
\frac{\pi}{0} \\
9 \\
\frac{\pi}{\pi} \\
\frac{\pi}{\pi} \\
z\end{array}$ & 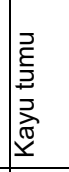 & 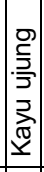 & 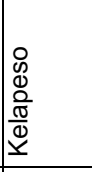 & 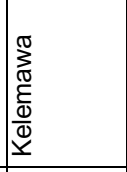 & 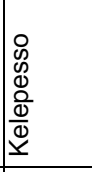 & 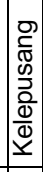 & 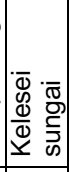 & 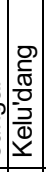 & $\begin{array}{l}. \\
\bar{a} \\
\underline{a} \\
\underline{a}\end{array}$ & 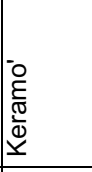 & 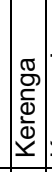 & 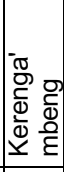 & 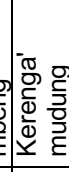 \\
\hline 운 & i্ & $\mid \begin{array}{c}\tilde{N} \\
\tilde{ల}\end{array}$ & ల్లి & 他 & مొ & L & 歺 & $\begin{array}{l}\infty \\
\infty \\
ల ్ m\end{array}$ & 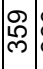 & @্ট & $\overline{\mathbf{o}}$ & స్ల్ & ల్ల \\
\hline
\end{tabular}




\begin{tabular}{|c|c|c|c|c|c|c|c|c|c|c|c|c|c|}
\hline 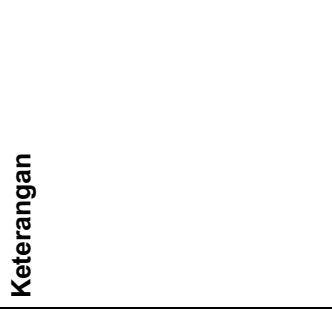 & 产 & 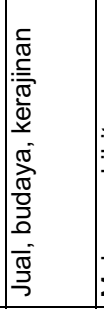 & 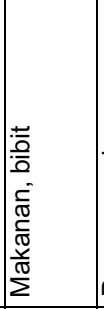 & 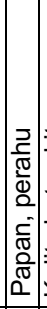 & 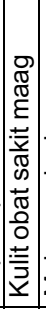 & 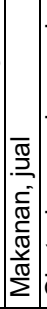 & 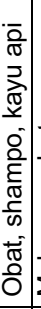 & 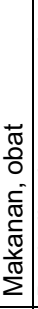 & 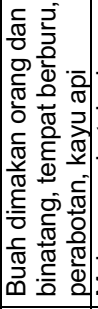 & 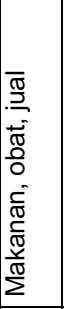 & 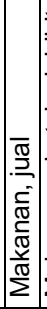 & 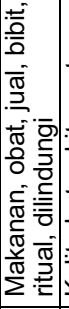 & 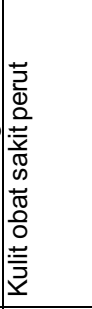 \\
\hline Total kegunaan & - & $m$ & N & N. & - & N & $N$ & $N$ & $\nabla$ & $m$ & $\sim$ & 0 & N \\
\hline Dilindungi/mulen & 1 & 1 & 1 & 1 & 1 & 1 & 1 & 1 & 1 & ' & 1 & $F$ & ' \\
\hline Status sosial/nama orang & 1 & ' & ' & ' & 1 & 1 & 1 & 1 & 1 & 1 & ' & ' & ' \\
\hline Kerajinan/pewarna & 1 & - & ' & ' & 1 & 1 & 1 & 1 & - & ' & ' & 1 & ' \\
\hline Upacara/budaya & 1 & - & ' & . & 1 & 1 & 1 & 1 & 1 & ' & 1 & - & ' \\
\hline Kebutuhan tak langsung & 1 & 1 & 1 & 1 & 1 & 1 & 1 & 1 & - & ' & 1 & 1 & - \\
\hline Hutan sumber bibit & 1 & 1 & - & 1 & 1 & 1 & 1 & ' & 1 & ' & 1 & - & ' \\
\hline Bungkus & 1 & 1 & ' & ' & 1 & 1 & 1 & ' & 1 & ' & 1 & 1 & ' \\
\hline Atap & - & 1 & ' & 1 & 1 & 1 & 1 & 1 & 1 & ' & 1 & 1 & ' \\
\hline Bahan pengikat/tali & 1 & 1 & ' & 1 & 1 & 1 & 1 & ' & 1 & ' & ' & 1 & ' \\
\hline Kayu api & 1 & ' & ' & - & 1 & 1. & - & ' & - & ' & ' & 1 & ' \\
\hline Ekonomi & 1 & - & ' & 1 & 1 & - & 1 & 1 & 1 & - & - & - & ' \\
\hline Bangunan/perahu & 1 & 1 & ' & - & 1 & 1 & . & 1 & 1 & ' & ' & 1 & ' \\
\hline Obat/racun & ' & I & ' & 1 & - & 1 & - & - & I & - & , & - & - \\
\hline Makanan & 1 & 1 & - & 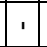 & 1 & - & 1 . & - & - & - & - & - & ' \\
\hline Pertanian & 1 & 1 & ' & 1 & 1 & - & 1 & 1 & 1 & 1 & - & 1 & ' \\
\hline Jekkau liar & 1 & 1 & 1 & ' & 1 & 1 & I & 1 & 1 & ' & ' & 1 & ' \\
\hline Hutan rimba & 1 & - & - & - & - & 1 & - & - & - & - & 1 & - & - \\
\hline Kategori & $\sum_{\models}^{\xi}$ & $\sum_{\models}^{\xi}$ & $\frac{\varepsilon}{\xi}$ & $\frac{\xi}{\Xi}$ & $\underset{f}{\frac{\xi}{J}}$ & $\frac{\varepsilon}{J}$ & $\frac{E}{\equiv}$ & $\underline{\Xi}$ & $\frac{\varepsilon}{\xi}$ & $\underline{\xi}$ & $\frac{E}{p}$ & $\underset{F}{E}$ & $\underline{\xi}$ \\
\hline $\begin{array}{l}\frac{c}{\frac{\pi}{\pi}} \\
\underline{\underline{\varepsilon}} \\
\frac{\pi}{\varepsilon} \\
\frac{\pi}{2} \\
\end{array}$ & $\bar{z}$ & 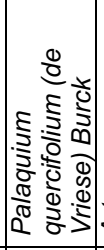 & 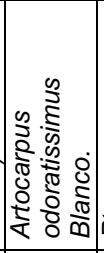 & 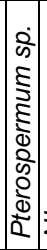 & $\bar{z}$ & 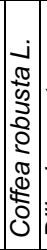 & 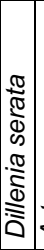 & \begin{tabular}{|l|}
0 \\
2 \\
5 \\
0 \\
0 \\
$\frac{2}{8}$ \\
0 \\
0 \\
$\frac{1}{4}$ \\
\end{tabular} & 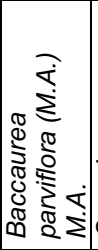 & 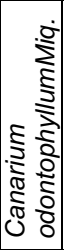 & 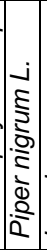 & 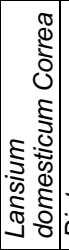 & 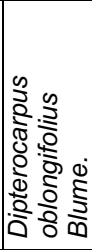 \\
\hline 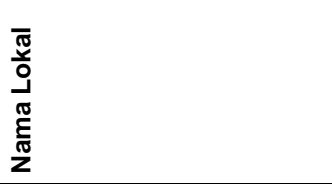 & $\begin{array}{l}\overline{\bar{z}} \\
\frac{\overline{2}}{\bar{Q}} \\
\underline{y}\end{array}$ & 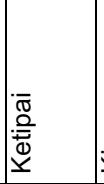 & $\frac{\mathfrak{c}}{\stackrel{\tilde{\pi}}{\underline{x}}}$ & & 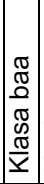 & : & $\frac{.0}{\frac{2}{2}}$ & $\frac{2}{\frac{2}{2}}$ & 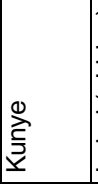 & 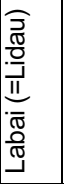 & 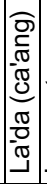 & 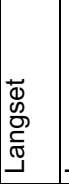 & 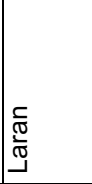 \\
\hline 운 & छ్రి & 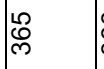 & @ & $\widehat{\hat{m}}$ & $\left|\begin{array}{l}\infty \\
0 \\
ల\end{array}\right|$ & : & $\begin{array}{l}R \\
m\end{array}$ & $\Gamma_{m}$ & $\underset{\substack{N \\
\text { Na }}}{\mathbb{N}}$ & $\underset{\substack{m \\
m}}{m}$ & 离 & $\underset{m}{\stackrel{N}{m}}$ & $\begin{array}{l}0 \\
\substack{m \\
m}\end{array}$ \\
\hline
\end{tabular}




\begin{tabular}{|c|c|c|c|c|c|c|c|c|c|c|c|c|c|c|}
\hline 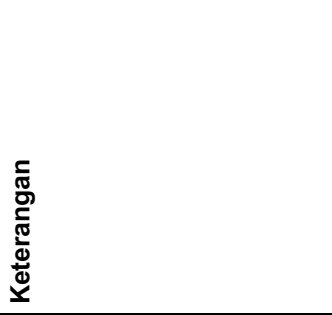 & 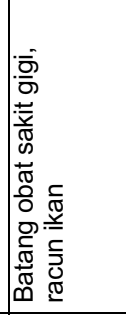 & 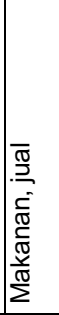 & 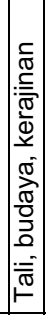 & 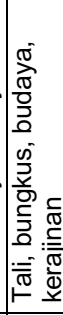 & 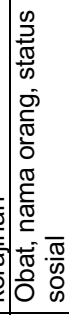 & 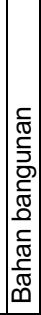 & 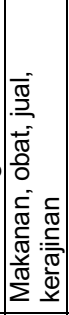 & 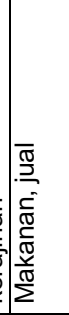 & 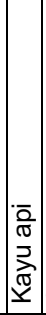 & 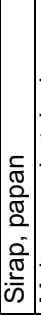 & 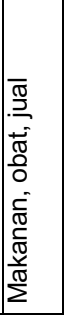 & 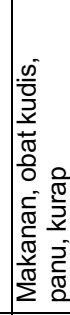 & 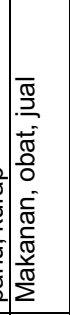 & 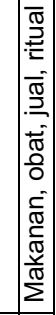 \\
\hline Total kegunaan & - & N & $m$ & A & N & - & A & N & - & - & $m$ & $m$ & $m$ & $\theta$ \\
\hline Dilindungi/mulen & 1 & 1 & 1 & 1 & 1 & 1 & 1 & ' & 1 & 1 & 1 & ' & 1 & ' \\
\hline Status sosial/nama orang & 1 & 1 & ' & 1 & - & 1 & 1 & ' & ' & 1 & ' & ' & ' & 1 \\
\hline Kerajinan/pewarna & ' & 1 & - & 1 & 1 & 1 & - & ' & 1 & 1 & ' & ' & ' & 1 \\
\hline Upacara/budaya & ' & ' & - & - & ' & 1 & , & ' & ' & 1 & ' & ' & ' & - \\
\hline Kebutuhan tak langsung & 1 & 1 & 1 & 1 & 1 & 1 & 1 & 1 & 1 & 1 & 1 & 1 & 1 & 1 \\
\hline Hutan sumber bibit & ' & ' & 1 & 1 & 1 & 1 & 1 & ' & 1 & ' & ' & ' & ' & 1 \\
\hline Bungkus & 1 & ' & 1 & - & ' & 1 & 1 & ' & 1 & 1 & I & - & ' & 1 \\
\hline Atap & 1 & ' & 1 & 1 & 1 & 1 & . & ' & $\cdot$ & 1 & ' & ' & 1 & 1 \\
\hline Bahan pengikat/tali & 1 & ' & - & - & ' & 1 & 1 & ' & 1 & 1 & 1 & ' & 1 & 1 \\
\hline Kayu api & 1 & ' & 1 & 1 & 1 & 1 & . & ' & - & 1 & ' & ' & 1 & 1 \\
\hline Ekonomi & 1 & - & 1 & 1 & 1 & 1 & - & - & 1 & 1 & - & ' & - & - \\
\hline Bangunan/perahu & 1 & 1 & 1 & 1 & 1 & - & 1 & ' & 1 & - & ' & ' & 1 & 1 \\
\hline Obat/racun & - & ' & 1 & 1 & - & 1 & - & ' & ' & 1 & - & - & - & - \\
\hline Makanan & 1 & - & 1 & - & 1 & 1 & - & - & 1 & 1 & - & - & - & - \\
\hline Pertanian & 1 & - & 1 & 1 & ' & 1 & 1 & - & 1 & 1 & - & - & - & 1 \\
\hline Jekkau liar & 1 & 1 & - & - & 1 & 1 & - & ' & - & 1 & . & ' & 1 & 1 \\
\hline Hutan rimba & - & 1 & 1 & - & - & - & 1 & ' & 1 & - & 1 & 1 & ' & 1 \\
\hline Kategori & $\underset{\vDash}{\xi}$ & $\mid \underline{\xi}$ & $\underline{\xi}$ & $\underline{\xi}$ & $\underline{\xi}$ & $\frac{\xi}{3}$ & $\underline{\xi}$ & $\sum_{\models}^{\xi}$ & $\frac{\xi}{J}$ & $\underline{\xi}$ & $\xi_{\models}^{\xi}$ & $\sum_{\models}^{\xi}$ & $\mid \underline{\xi}$ & $\underset{\xi}{\xi}$ \\
\hline 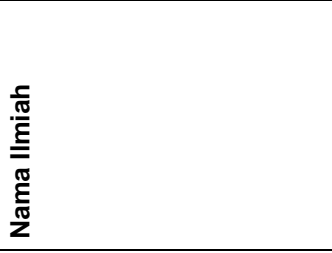 & 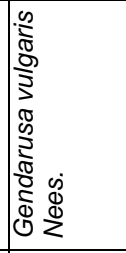 & 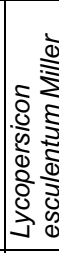 & 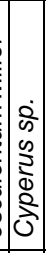 & 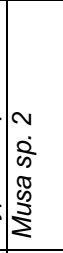 & 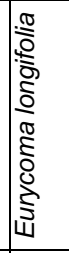 & 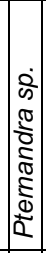 & 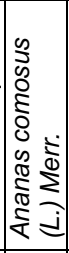 & 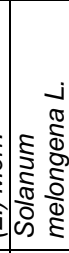 & & $\bar{z}$ & 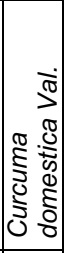 & 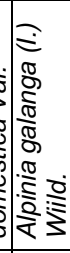 & 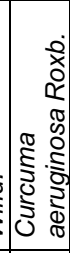 & 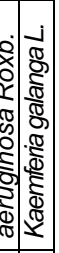 \\
\hline 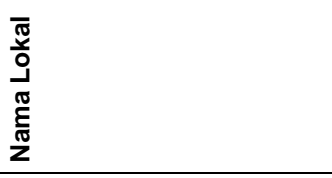 & 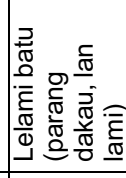 & 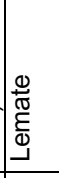 & \begin{tabular}{|l|}
- \\
$\pi$ \\
\\
\\
\\
\\
\end{tabular} & 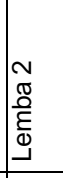 & 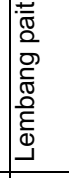 & 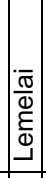 & 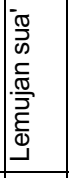 & $\begin{array}{l}0 \\
0 \\
0 \\
0 \\
0 \\
0 \\
\\
\\
\end{array}$ & 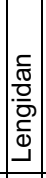 & $\begin{array}{l} \\
\pm \\
\infty \\
\infty \\
\Xi \\
\end{array}$ & $\begin{array}{l}\frac{\pi}{\bar{a}} \\
\frac{\pi}{a} \\
-\frac{\pi}{1}\end{array}$ & 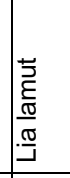 & 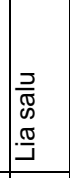 & 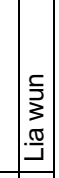 \\
\hline 운 & $\hat{\widehat{N}}$ & $\stackrel{\infty}{\stackrel{\infty}{m}}$ & 昰 & 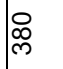 & ז్ & ] & 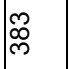 & 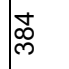 & $\mid \begin{array}{l}\infty \\
\infty \\
m\end{array}$ & & 依 & $\begin{array}{l}\infty \\
\infty \\
m\end{array}$ & 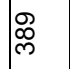 & প্লি \\
\hline
\end{tabular}




\begin{tabular}{|c|c|c|c|c|c|c|c|c|c|c|c|c|}
\hline 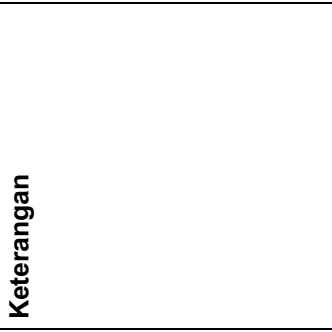 & 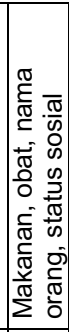 & $\frac{1}{0}$ & 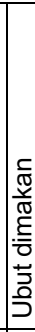 & 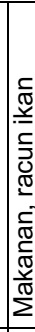 & 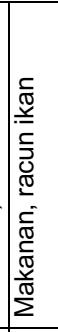 & 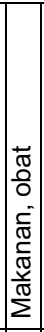 & 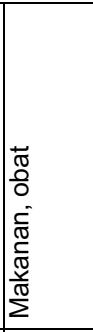 & 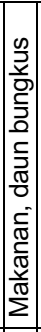 & 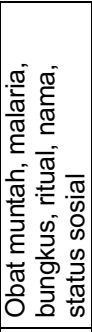 & 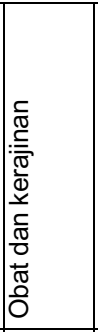 & 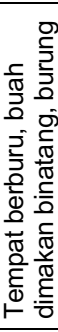 & 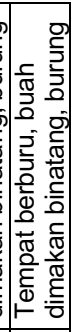 \\
\hline Total kegunaan & $m$ & - & - & N & N & $\sim$ & N & $N$ & $\infty$ & N & F & - \\
\hline Dilindungi/mulen & 1 & ' & ' & 1 & 1 & 1 & ' & 1 & ' & ' & ' & 1 \\
\hline Status sosial/nama orang & - & ' & ' & , & 1 & 1 & ' & ' & - & ' & ' & ' \\
\hline Kerajinan/pewarna & 1 & ' & ' & I & 1 & 1 & 1 & I & ' & - & ' & ' \\
\hline Upacara/budaya & , & ' & , & , & . &. & , & 1 & - & , & ' & , \\
\hline Kebutuhan tak langsung & 1 & ' & ' & I & 1 & 1 & 1 & 1 & ' & 1 & - & - \\
\hline Hutan sumber bibit & 1 & I & ' & I & I & 1 & I & 1 & - & 1 & ' & ' \\
\hline Bungkus & 1 & ' & ' & 1 & 1 & 1 & 1 & - & - & ' & ' & ' \\
\hline Atap & 1 & ' & 1 & I & 1 & 1 & ' & 1 & ' & 1 & ' & ' \\
\hline Bahan pengikat/tali & 1 & ' & ' & I & 1 & 1 & . & 1 & ' & ' & ' & ' \\
\hline Kayu api & 1 & ' & 1 & I & 1 & 1 & I & 1 & ' & ' & ' & ' \\
\hline Ekonomi & 1 & ' & 1 & 1 & 1 & 1 & I & . & ' & 1 & ' & ' \\
\hline Bangunan/perahu & 1 & ' & ' & ' & 1 & 1 & I & I & ' & ' & ' & ' \\
\hline Obat/racun & - & - & ' & F & - & - & - & 1 & - & - & ' & ' \\
\hline Makanan & - & ' & - & - & - & - & - & - & 1 & 1 & ' & ' \\
\hline Pertanian & 1 & ' & . & I & 1 & - & - & 1 & 1 & ' & ' & ' \\
\hline Jekkau liar & - & ' & I & $F$ & - & 1 & I & - & ' & ' & 1 & ' \\
\hline Hutan rimba & 1 & - & - & $F$ & $F$ & 1 & 1 & - & - & - & - & - \\
\hline Kategori & $\underline{\xi}$ & $\underline{\xi}$ & $\frac{\varepsilon}{F}$ & $\underline{\xi}$ & $\underset{\vDash}{\xi}$ & $\underline{\xi}$ & $\underset{\models}{\xi}$ & $\frac{\varepsilon}{F}$ & $\underline{\underline{F}}$ & $\underline{\xi}$ & $\xi_{\models}^{\xi}$ & $\underline{\xi}$ \\
\hline 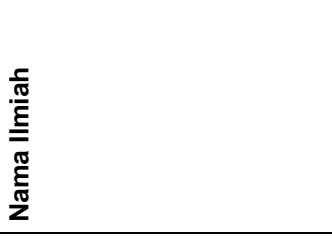 & 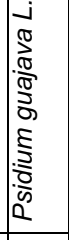 & 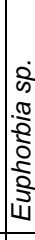 & 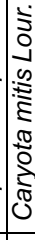 & 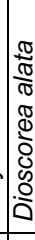 & 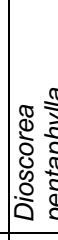 & 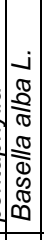 & 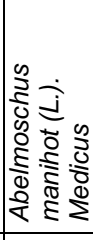 & 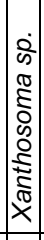 & 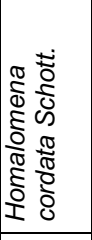 & 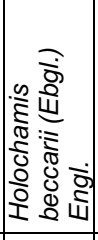 & $\begin{array}{l}\dot{0} \\
0 \\
5 \\
5 \\
0 \\
01 \\
1\end{array}$ & 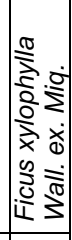 \\
\hline 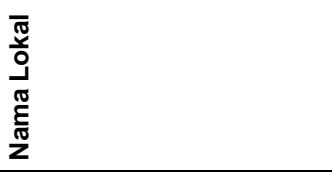 & ב气 & 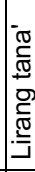 & $\frac{\bar{m}}{\exists}$ & 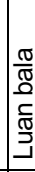 & 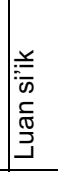 & $\frac{0}{3}$ & $\begin{array}{l}\frac{3}{\sqrt{3}} \\
\frac{3}{0} \\
\frac{0}{0} \\
\frac{0}{3}\end{array}$ & 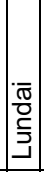 & 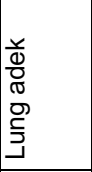 & 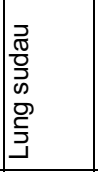 & $\begin{array}{l}\text { 兰 } \\
\text { 孚 }\end{array}$ & 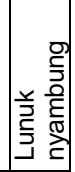 \\
\hline 울 & হ্লি & & ক্লি & স্লি & ফ্ল & 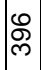 & 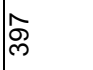 & 文 & প্লে & ষ্ণ & চ্ণ & $ָ$ \\
\hline
\end{tabular}




\begin{tabular}{|c|c|c|c|c|c|c|c|c|c|c|c|c|c|}
\hline 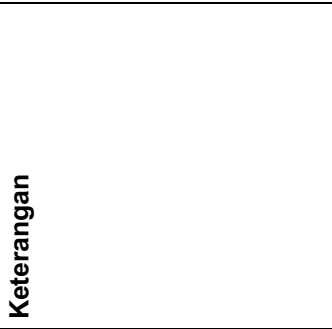 & 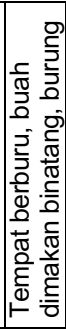 & 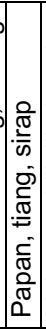 & 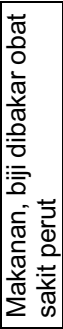 & 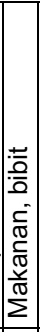 & 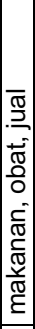 & 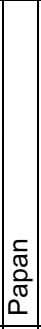 & 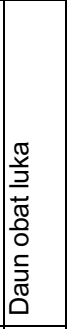 & 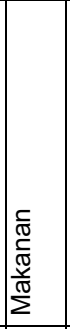 & 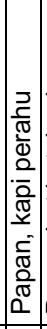 & 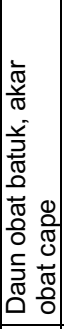 & 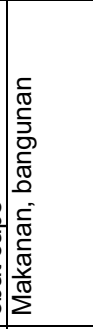 & 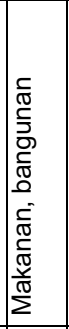 & 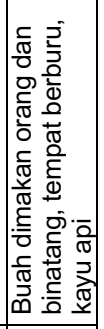 \\
\hline Total kegunaan & - & - & $\sim$ & $\sim$ & $m$ & - & N & - & - & - & N & N & - \\
\hline Dilindungi/mulen & 1 & 1 & ' & 1 & 1 & 1 & ' & ' & 1 & ' & ' & ' & ' \\
\hline Status sosial/nama orang & 1 & 1 & 1 & 1 & 1 & 1 & ' & ' & 1 & ' & ' & ' & ' \\
\hline Kerajinan/pewarna & 1 & 1 & 1 & 1 & 1 & 1 & ' & ' & ' & ' & 1 & ' & ' \\
\hline Upacara/budaya & 1 & 1 & ' & 1 & 1 & 1 & ' & ' & 1 & ' & ' & ' & ' \\
\hline Kebutuhan tak langsung & - & $\cdot$ & 1 & 1 & 1 & 1 & 1 & ' & 1 & 1 & ' & ' & ' \\
\hline Hutan sumber bibit & 1 & 1 & ' & - & 1 & 1 & ' & ' & 1 & 1 & ' & ' & ' \\
\hline Bungkus & 1 & 1 & ' & 1 & 1 & 1 & 1 & ' & 1 & ' & ' & ' & ' \\
\hline Atap & 1 & 1 & 1 & 1 & 1 & 1 & . & ' & 1 & ' & 1 & ' & ' \\
\hline Bahan pengikat/tali & 1 & 1 & ' & 1 & 1 & 1 & 1 & ' & 1 & ' & ' & ' & ' \\
\hline Kayu api & 1 & ' & 1 & 1 & 1 & 1 & - & ' & 1 & 1 & ' & ' & ' \\
\hline Ekonomi & 1 & 1 & 1 & 1 & - & 1 & 1 & 1 & 1 & 1 & 1 & 1 & ' \\
\hline Bangunan/perahu & 1 & - & 1 & 1 & 1 & - & 1 & ' & - & I & - & - & ' \\
\hline Obat/racun & 1 & 1 & - & 1 & - & 1 & - & ' & 1 & - & 1 & ' & ' \\
\hline Makanan & 1 & 1 & - & - & - & 1 & 1 & - & $\cdot$ & ' & - & - & - \\
\hline Pertanian & 1 & $\cdot$ & 1 & 1 & - & $\cdot$ & 1 & 1 & 1 & - & 1 & ' & ' \\
\hline Jekkau liar & 1 & 1 & 1 & 1 & 1 & 1 & - & 1 & 1 & ' & 1 & 1 & ' \\
\hline Hutan rimba & - & - & - & - & 1 & - & 1 & - & - & 1 & - & - & - \\
\hline Kategori & $\underline{\xi}$ & $\underset{f}{\underline{\xi}}$ & $\frac{\varepsilon}{\underline{F}}$ & $\frac{\varepsilon}{\underline{F}}$ & $\underline{\underline{g}}$ & $\underset{\xi}{\underline{\xi}}$ & $\underset{\models}{\xi}$ & $\underset{\xi}{\Xi}$ & $\underset{\xi}{\Xi}$ & $\underset{\xi}{\xi}$ & $\underline{\xi}$ & $\underset{\xi}{\xi}$ & $\underline{\xi}$ \\
\hline $\begin{array}{l}\frac{\frac{\pi}{\pi}}{E} \\
\underline{\underline{E}} \\
\frac{\pi}{\frac{\pi}{\pi}} \\
\frac{\pi}{Z}\end{array}$ & $\begin{array}{l}0 \\
\text { s } \\
0 \\
3 \\
0 \\
0\end{array}$ & $\bar{z}$ & 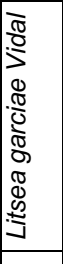 & 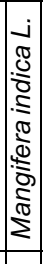 & 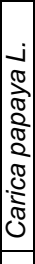 & $\bar{z}$ & 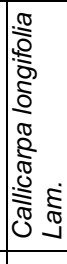 & 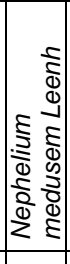 & $\frac{1}{2}$ & 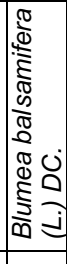 & 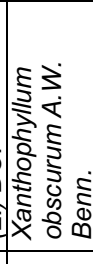 & 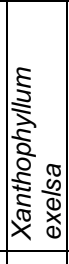 & $\begin{array}{l}0 \\
0 \\
0 \\
0 \\
0 \\
5 \\
\mathbb{2} \\
0 \\
0 \\
0 \\
0\end{array}$ \\
\hline 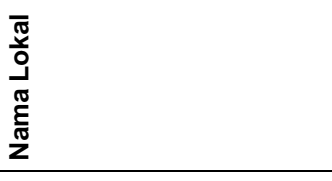 & 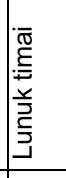 & \begin{tabular}{|c|}
$\frac{1}{\mathbb{0}}$ \\
$\mathbb{\pi}$ \\
$\Sigma$
\end{tabular} & 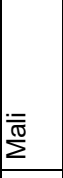 & 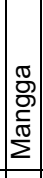 & & 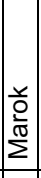 & 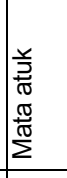 & 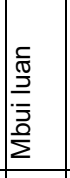 & 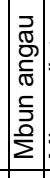 & 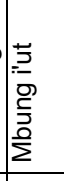 & 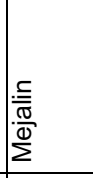 & 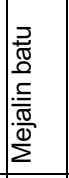 & 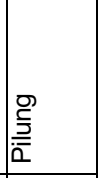 \\
\hline$\stackrel{\circ}{z}$ & 弚 & 竎 & 驾 & & & & 宇 & $\frac{0}{\dot{\theta}}$ & $\frac{\check{\sigma}}{\mp}$ & $\frac{\mathbb{Z}}{\stackrel{\sigma}{*}}$ & $\frac{m}{q}$ & $\frac{J}{\sigma}$ & $\frac{10}{\square}$ \\
\hline
\end{tabular}




\begin{tabular}{|c|c|c|c|c|c|c|c|c|c|c|c|c|c|}
\hline 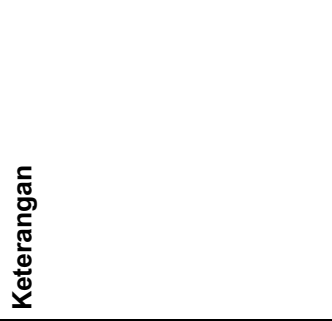 & 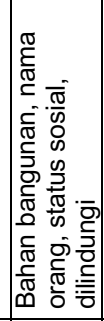 & \begin{tabular}{|l} 
\\
\\
$\frac{\pi}{0}$ \\
0 \\
\end{tabular} & \begin{tabular}{|l} 
\\
$-\pi$ \\
$\frac{\pi}{0}$ \\
\end{tabular} & 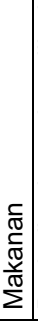 & 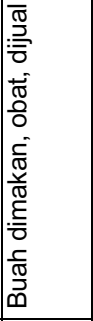 & 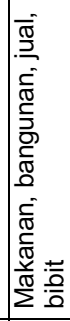 & 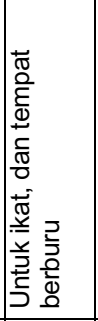 & 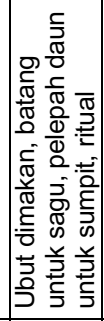 & 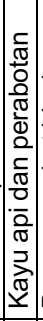 & 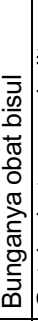 & 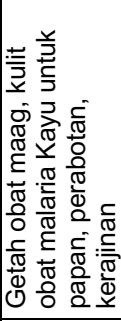 & 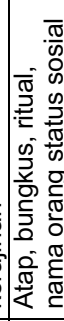 & 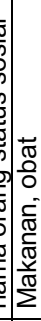 \\
\hline Total kegunaan & $m$ & - & - & - & $m$ & A & N & $m$ & N & - & $m$ & 10 & N \\
\hline Dilindungi/mulen & - & 1 & 1 & 1 & 1 & 1 & 1 & 1 & 1 & ' & 1 & ' & ' \\
\hline Status sosial/nama orang & - & ' & 1 & 1 & 1 & 1 & ' & 1 & 1 & 1 & 1 & - & ' \\
\hline Kerajinan/pewarna & 1 & ' & 1 & 1 & 1 & 1 & 1 & - & 1 & $\cdot$ & - & - & ' \\
\hline Upacara/budaya & , & ' & . & 1 & , & , & ' & - & 1 & 1 & ' & - & ' \\
\hline Kebutuhan tak langsung & 1 & ' & 1 & 1 & 1 & 1 & - & 1 & - & 1 & 1 & 1 & ' \\
\hline Hutan sumber bibit & 1 & ' & 1 & 1 & 1 & - & 1 & ' & 1 & ' & 1 & ' & ' \\
\hline Bungkus & 1 & ' & 1 & 1 & 1 & 1 & 1 & ' & 1 & ' & ' & - & ' \\
\hline Atap & 1 & 1 & 1 & 1 & 1 & 1 & 1 & 1 & 1 & 1 & 1 & - & ' \\
\hline Bahan pengikat/tali & 1 & ' & 1 & 1 & 1 & 1 & - & 1 & 1 & 1 & 1 & ' & ' \\
\hline Kayu api & 1 & ' & 1 & 1 & ' & 1 & ' & ' & - & $\cdot$ & ' & ' & ' \\
\hline Ekonomi & 1 & ' & 1 & 1 & - & - & ' & 1 & 1 & 1 & 1 & ' & ' \\
\hline Bangunan/perahu & - & ' & 1 & 1 & 1 & - & 1 & ' & 1 & 1 & - & 1 & ' \\
\hline Obat/racun & 1 & - & - & 1 & - & 1 & 1 & 1 & 1 & - & - & 1 & - \\
\hline Makanan & 1 & 1 & 1 & - & - & - & 1 & - & 1 & 1 & 1 & 1 & - \\
\hline Pertanian & 1 & ' & 1 & 1 & - & 1 & 1 & 1 & 1 & 1 & 1 & 1 & ' \\
\hline Jekkau liar & 1 & 1 & - & 1 & . & 1 & - & . & 1 & - & . & - & ' \\
\hline Hutan rimba & - & $F$ & 1 & - & 1 & - & - & - & - & 1 & - & - & $r$ \\
\hline Kategori & $\varliminf_{\vdash}^{\xi}$ & $\underline{\Xi}$ & $\underline{\xi}$ & $\underline{\Xi}$ & $\underline{\xi}$ & $\mid \underline{\xi}$ & $\mid \underline{\xi}$ & $\sum_{\models}^{\varepsilon}$ & $\frac{\xi}{F}$ & $\frac{\varepsilon}{J}$ & $\underline{\xi}$ & $\underline{\xi}$ & $\frac{\varepsilon}{\xi}$ \\
\hline 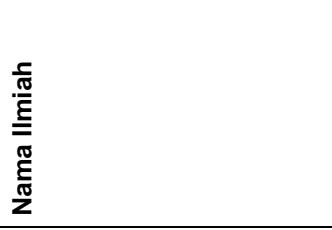 & $\bar{z}$ & $\Sigma$ & 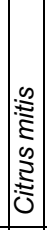 & & 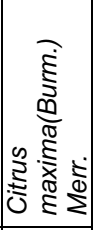 & 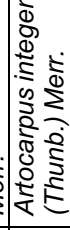 & 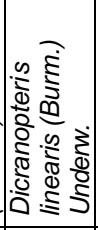 & 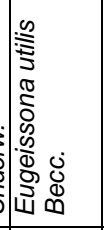 & 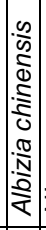 & $\bar{z}$ & 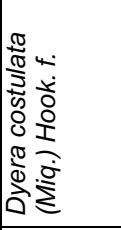 & 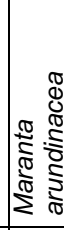 & 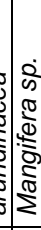 \\
\hline 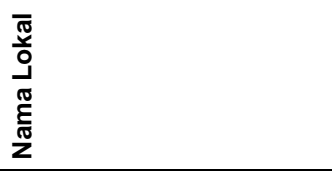 & 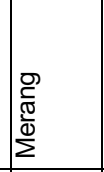 & 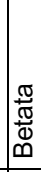 & 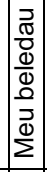 & 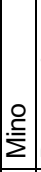 & 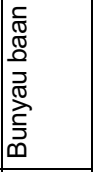 & $\begin{array}{l}\frac{c}{\mathbb{N}} \\
\frac{\mathbb{N}}{\mathbb{N}} \\
Z\end{array}$ & 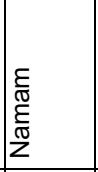 & 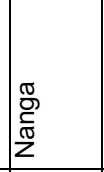 & $\frac{0}{2}$ & 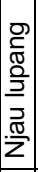 & 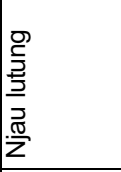 & 产 & 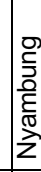 \\
\hline 운 & $\frac{\varrho}{\sigma}$ & $\frac{\sqrt{\sigma}}{\sigma}$ & $\frac{\infty}{q}$ & $\frac{O}{\square}$ & $\underset{\sim}{\stackrel{\sim}{*}}$ & $\bar{\sim}$ & $\underset{\mathfrak{F}}{\mathbb{N}}$ & $\underset{\sim}{\stackrel{F}{*}}$ & $\stackrel{\sim}{\Im}$ & $\stackrel{\mathfrak{R}}{\underset{\sim}{*}}$ & $\underset{\sim}{\mathscr{F}}$ & $\stackrel{\sim}{\mathcal{F}}$ & $\stackrel{\infty}{\sim} \underset{\sim}{ }$ \\
\hline
\end{tabular}




\begin{tabular}{|c|c|c|c|c|c|c|c|c|c|c|c|c|c|c|}
\hline 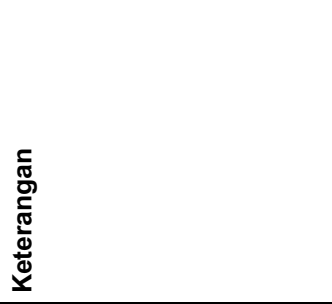 & 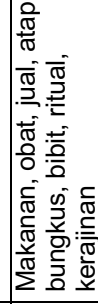 & 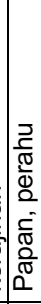 & 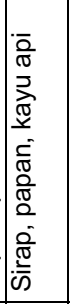 & 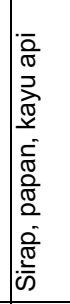 & 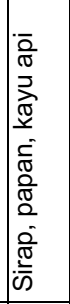 & 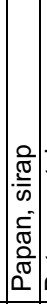 & 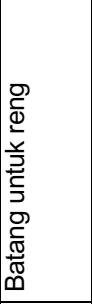 & 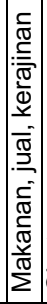 & 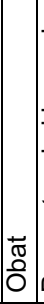 & 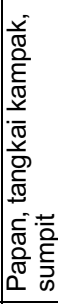 & 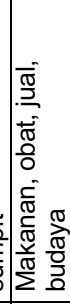 & 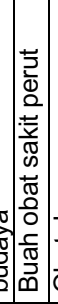 & 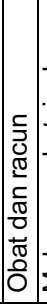 & 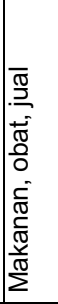 \\
\hline Total kegunaan & $\infty$ & - & $m$ & $m$ & $m$ & - & N & $m$ & - & $m$ & $m$ & $N$ & $\sim$ & $m$ \\
\hline Dilindungi/mulen & ' & ' & 1 & 1 & ' & 1 & 1 & 1 & ' & ' & ' & 1 & ' & ' \\
\hline Status sosial/nama orang & ' & ' & ' & ' & ' & ' & 1 & 1 & 1 & ' & ' & ' & 1 & ' \\
\hline Kerajinan/pewarna & - & ' & ' & 1 & 1 & 1 & 1 & - & 1 & - & ' & ' & 1 & ' \\
\hline Upacara/budaya & - & ' & ' & ' & ' & . & , & ' & 1 & - & ' & . & 1 & , \\
\hline Kebutuhan tak langsung & ' & ' & 1 & 1 & 1 & 1 & 1 & $\cdot$ & 1 & ' & ' & 1 & 1 & ' \\
\hline Hutan sumber bibit & - & ' & 1 & ' & 1 & 1 & 1 & ' & 1 & ' & ' & 1 & - & I \\
\hline Bungkus & - & ' & ' & 1 & 1 & 1 & 1 & ' & ' & ' & ' & . & 1 & ' \\
\hline Atap & - & ' & - & - & - & 1 & 1 & $\cdot$ & $\cdot$ & 1 & ' & . & 1 & ' \\
\hline Bahan pengikat/tali & 1 & ' & 1 & 1 & ' & ' & 1 & ' & 1 & 1 & ' & 1 & 1 & ' \\
\hline Kayu api & ' & ' & - & - & - & 1 & 1 & $\cdot$ & 1 & ' & ' & . & . & ' \\
\hline Ekonomi & - & ' & 1 & 1 & 1 & 1 & 1 & - & 1 & ' & - & . & 1. & - \\
\hline Bangunan/perahu & ' & - & - & - & - & - & - & 1 & 1 & - & ' & . & 1 & ' \\
\hline Obat/racun & - & ' & I & 1 & 1 & ' & 1 & ' & - & ' & - & - & - & - \\
\hline Makanan & - & 1 & 1 & 1 & 1 & 1 & - & - & $\cdot$ & ' & - & - & 1 & - \\
\hline Pertanian & I & ' & 1 & 1 & 1 & 1 & 1 & - & 1 & ' & - & ' & 1 & 1 \\
\hline Jekkau liar & - & 1 & 1 & 1 & 1 & 1 & 1 & 1 & - & ' & 1 & - & 1 & ' \\
\hline Hutan rimba & - & - & - & - & - & - & - & 1 & - & - & ' & 1 r & - & - \\
\hline Kategori & $\sum_{\vdash}^{\varepsilon}$ & $\xi \xi$ & $\underset{\xi}{\underline{\xi}}$ & $\underset{\risingdotseq}{\xi}$ & $\underset{\mathfrak{F}}{\underline{\xi}}$ & $\underset{\mathfrak{F}}{\underline{\xi}}$ & $\underline{\xi}$ & $\underset{\mathfrak{F}}{\underline{\xi}}$ & $\sum_{\underline{F}}^{\xi}$ & 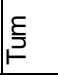 & $\underset{\vDash}{\underline{\xi}}$ & $\underset{F}{\xi}$ & $\underset{F}{\xi}$ & 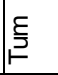 \\
\hline $\begin{array}{l}\frac{\sqrt{\pi}}{\frac{\pi}{\pi}} \\
\frac{\underline{\underline{\pi}}}{\bar{\pi}} \\
\frac{\mathrm{\sigma}}{\pi} \\
\frac{\pi}{2}\end{array}$ & 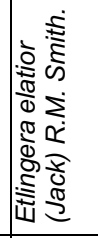 & 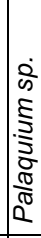 & 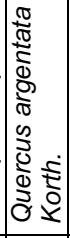 & 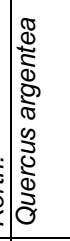 & 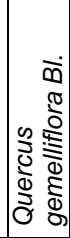 & $\begin{array}{l} \\
\dot{2} \\
\frac{2}{2} \\
\frac{8}{2} \\
\frac{8}{2} \\
\frac{1}{2}\end{array}$ & 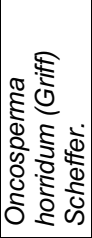 & 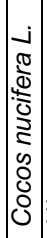 & $\bar{z}$ & $\bar{z}$ & 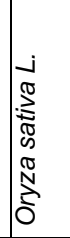 & 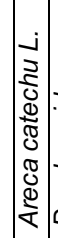 & 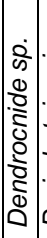 & 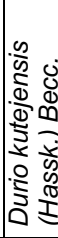 \\
\hline 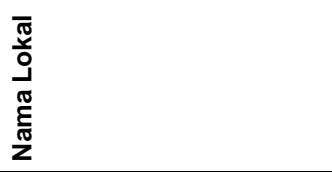 & 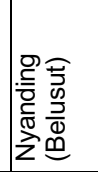 & $\frac{0}{\frac{0}{\pi}}$ & 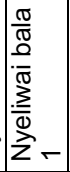 & 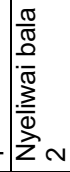 & 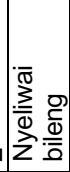 & $\frac{\pi}{\frac{\pi}{\pi}}$ & 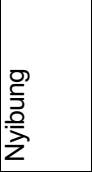 & হ & 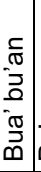 & 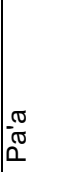 & $\begin{array}{l}\bar{\Phi} \\
\overline{0} \\
\overline{0} \\
0\end{array}$ & 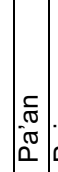 & & 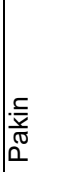 \\
\hline 운 & $\underset{\sim}{\stackrel{\text { }}{*}}$ & ஜ্ণি & 弚 & $\underset{\sim}{\mathscr{\sim}}$ & $\stackrel{\mathscr{্}}{\mathscr{\wp}}$ & ঙ্ & 怘 & $\begin{array}{l}\infty \\
\tilde{y} \\
\forall\end{array}$ & & 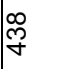 & প্ণ্ & g & $\bar{f}$ & F \\
\hline
\end{tabular}




\begin{tabular}{|c|c|c|c|c|c|c|c|c|c|c|c|c|}
\hline 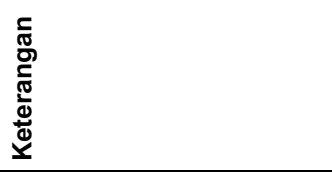 & 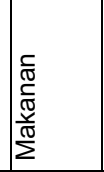 & 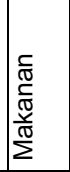 & 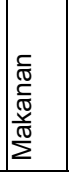 & 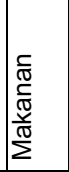 & 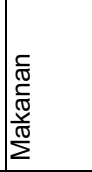 & 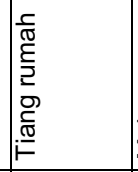 & 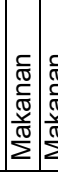 & & $\begin{array}{l}\frac{\nwarrow}{\pi} \\
\frac{\pi}{\pi} \\
\frac{\pi}{\pi} \\
\Sigma \\
\Sigma\end{array}$ & 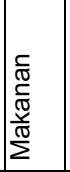 & 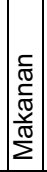 & 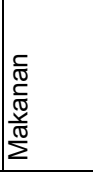 \\
\hline Total kegunaan & - & - & - & - & - & N & -7 & $-r$ & - & - & - & - \\
\hline Dilindungi/mulen & 1 & 1 & 1 & ' & 1 & ' & \begin{tabular}{|l|l}
1 & 1
\end{tabular} & ' & ' & ' & 1 & 1 \\
\hline Status sosial/nama orang & 1 & 1 & 1 & 1 & 1 & 1 & \begin{tabular}{l|l}
1 & 1 \\
\end{tabular} & ' & ' & ' & 1 & 1 \\
\hline Kerajinan/pewarna & 1 & 1 & 1 & 1 & 1 & 1 & $\begin{array}{ll}1 & 1\end{array}$ & ' & ' & 1 & 1 & 1 \\
\hline Upacara/budaya & ' & ' & 1 & ' & ' & ' & 1, & ' & ' & ' & ' & ' \\
\hline Kebutuhan tak langsung & 1 & 1 & 1 & 1 & 1 & ' & \begin{tabular}{|l|l}
1 & 1 \\
\end{tabular} & ' & ' & 1 & 1 & 1 \\
\hline Hutan sumber bibit & 1 & ' & 1 & 1 & ' & ' & \begin{tabular}{l|l}
1 & 1
\end{tabular} & ' & ' & ' & ' & 1 \\
\hline Bungkus & 1 & ' & 1 & ' & 1 & ' & \begin{tabular}{|l|l}
1 & 1 \\
\end{tabular} & ' & ' & ' & 1 & 1 \\
\hline Atap & ' & ' & ' & ' & 1 & ' & \begin{tabular}{|l|l}
1 & \\
\end{tabular} & ' & ' & ' & 1 & 1 \\
\hline Bahan pengikat/tali & 1 & 1 & ' & 1 & 1 & ' & \begin{tabular}{l|l}
1 & 1
\end{tabular} & ' & ' & ' & 1 & 1 \\
\hline Kayu api & 1 & ' & ' & 1 & ' & - & \begin{tabular}{|l|l} 
& 1 \\
\end{tabular} & ' & ' & ' & ' & 1 \\
\hline Ekonomi & 1 & 1 & 1 & 1 & ' & ' & 1,1 & ' & ' & 1 & 1 & 1 \\
\hline Bangunan/perahu & 1 & 1 & 1 & 1 & 1 & - & $\begin{array}{ll}1 & 1 \\
\end{array}$ & ' & ' & 1 & 1 & 1 \\
\hline Obat/racun & ' & ' & ' & ' & 1 & ' & \begin{tabular}{|l|l}
1 & 1
\end{tabular} & ' & ' & ' & ' & ' \\
\hline Makanan & - & - & - & - & - & 1 & -7 & $-r$ & $\leftarrow$ & - & - & - \\
\hline Pertanian & ' & 1 & 1 & 1 & 1 & ' & \begin{tabular}{l|l}
1 & 1 \\
\end{tabular} & ' & ' & 1 & 1 & 1 \\
\hline Jekkau liar & - & - & - & - & 1 & ' & 17 & $F$ & ' & I & - & I \\
\hline Hutan rimba & - & - & - & - & - & - & $-F$ & $-r$ & 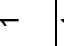 & - & 1 & - \\
\hline Kategori & $\underset{\xi}{\xi}$ & $\underline{\xi}$ & $\underset{F}{\xi}$ & $\underset{\xi}{\underline{\xi}}$ & $\underset{\mathfrak{F}}{\underline{F}}$ & $\varliminf_{\models}^{\xi}$ & $\stackrel{\varepsilon}{\xi} \stackrel{\varepsilon}{\models}$ & $\underline{\xi}$ & $\underline{\xi \xi}$ & $\underset{\xi}{\xi}$ & $\underset{\xi}{\xi}$ & 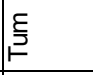 \\
\hline $\begin{array}{l}\frac{c}{\frac{\pi}{\pi}} \\
\underline{\underline{\varepsilon}} \\
\frac{\pi}{\varepsilon} \\
\frac{\pi}{2}\end{array}$ & 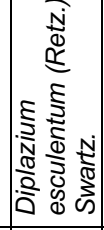 & 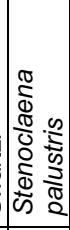 & 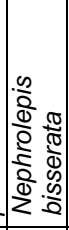 & 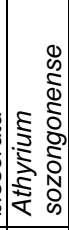 & 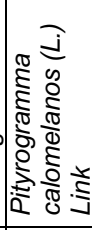 & 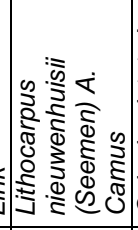 & 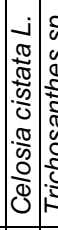 & & 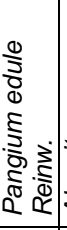 & 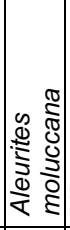 & & 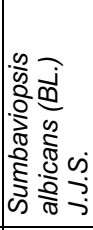 \\
\hline 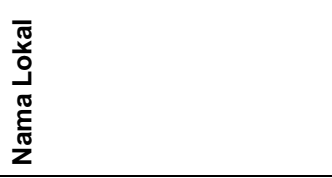 & 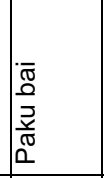 & \begin{tabular}{|l}
$\frac{\pi}{\pi}$ \\
$\frac{\Omega}{\pi}$ \\
$\frac{\partial}{\pi}$ \\
$\alpha$ \\
0
\end{tabular} & 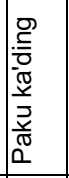 & 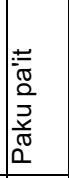 & $\begin{array}{l}\frac{0}{\omega} \\
\frac{1}{\pi} \\
\frac{1}{0} \\
0\end{array}$ & 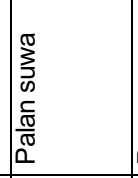 & 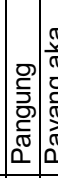 & 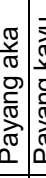 & 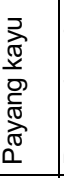 & 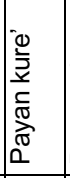 & 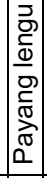 & 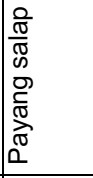 \\
\hline 울 & $\stackrel{\mathscr{P}}{\&}$ & 过 & 过 & 过 & 夺 & $\underset{f}{\mathscr{f}}$ & g & L) & Бु & 跑 & 色 & 离 \\
\hline
\end{tabular}




\begin{tabular}{|c|c|c|c|c|c|c|c|c|c|c|c|c|c|c|c|}
\hline 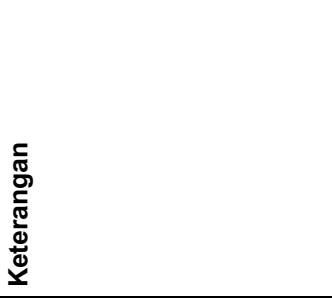 & 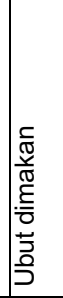 & 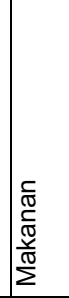 & 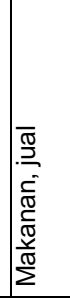 & 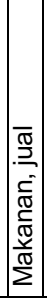 & 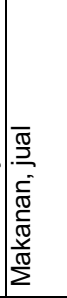 & 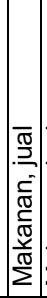 & 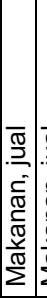 & 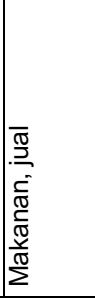 & 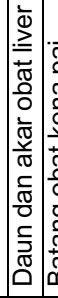 & 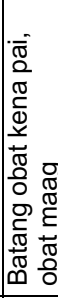 & 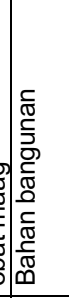 & 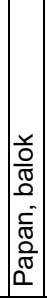 & 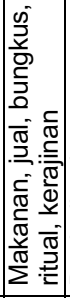 & 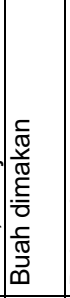 & 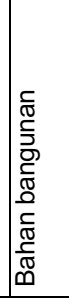 \\
\hline Total kegunaan & - & - & a & $\sim$ & $\sim$ & $\sim$ & $\sim c$ & $N$ & $-r$ & - & - & - & $\bullet$ & - & - \\
\hline Dilindungi/mulen & 1 & 1 & 1 & 1 & 1 & 1 & ' & 1 & ' & 1 & 1 & 1 & ' & 1 & 1 \\
\hline Status sosial/nama orang & ' & 1 & 1 & 1 & 1 & 1 & 1 & 1 & ' & 1 & ' & 1 & ' & 1 & ' \\
\hline Kerajinan/pewarna & ' & 1 & 1 & 1 & 1 & 1 & 1 & ' & ' & 1 & ' & 1 & - & 1 & ' \\
\hline Upacara/budaya & ' & , & ' & 1 & . & ' & 1 & , & . & ' & ' & , & - & ' & ' \\
\hline Kebutuhan tak langsung & 1 & 1 & 1 & 1 & 1 & 1 & 1 & 1 & 1 & ' & ' & 1 & 1 & 1 & 1 \\
\hline Hutan sumber bibit & ' & 1 & ' & 1 & 1 & 1 & 1 & 1 & 1 & 1 & ' & ' & ' & ' & 1 \\
\hline Bungkus & ' & 1 & 1 & 1 & 1 & 1 & 1 & 1 & 1 & 1 & ' & ' & - & 1 & ' \\
\hline Atap & ' & 1 & 1 & 1 & 1 & 1 & 1 & ' & ' & 1 & ' & $\cdot$ & ' & ' & 1 \\
\hline Bahan pengikat/tali & ' & 1 & 1 & 1 & 1 & 1 & . & ' & ' & ' & ' & ' & - & ' & 1 \\
\hline Kayu api & ' & 1 & 1 & 1 & 1 & 1 & 1 & ' & 1 & ' & ' & 1 & ' & ' & 1 \\
\hline Ekonomi & 1 & 1 & - & - & - & - & - & - & 1 & 1 & ' & 1 & - & 1 & 1 \\
\hline Bangunan/perahu & ' & 1 & 1 & 1 & ' & 1 & 1 & 1 & 1 & ' & - & - & ' & 1 & - \\
\hline Obat/racun & 1 & 1 & 1 & 1 & 1 & 1 & 1 & 1 & $-\sigma$ & - & 1 & ' & ' & 1 & 1 \\
\hline Makanan & - & - & - & - & - & - & - & - & 1 & ' & ' & 1 & - & - & ' \\
\hline Pertanian & ' & 1 & - & - & - & - & - & - & 1 & 1 & ' & 1 & ' & - & ' \\
\hline Jekkau liar & - & - & 1 & 1 & ' & 1 & 1 & 1 & - & ' & 1 & 1 & - & 1 & 1 \\
\hline Hutan rimba & - & - & 1 & 1 & 1 & 1 & 1 & 1 & 17 & - & - & - & ' & 1 & - \\
\hline Kategori & $\underline{\xi}$ & $\underline{\xi}$ & $\underline{\xi}$ & $\underline{\xi}$ & $\underline{\xi}$ & $\frac{\xi}{\xi}$ & $\frac{E}{F}$ & $\underline{\xi}$ & 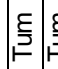 & $\underline{\xi}$ & $\xi_{\models}^{\xi}$ & $\sum_{\models}^{\xi}$ & $\underline{\xi}$ & $\underline{\xi}$ & $\underline{\xi}$ \\
\hline 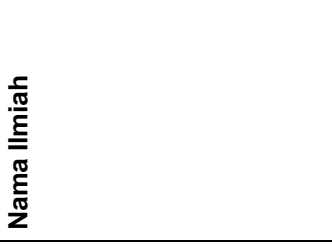 & 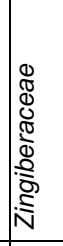 & 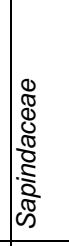 & 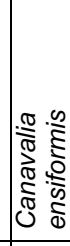 & 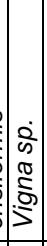 & 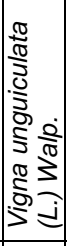 & 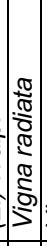 & \begin{tabular}{|c|} 
\\
\\
2 \\
0 \\
0 \\
0 \\
5 \\
5 \\
5
\end{tabular} & 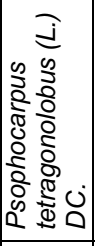 & & $\bar{z}$ & 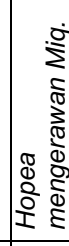 & : & 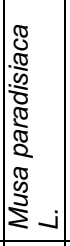 & 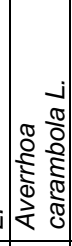 & 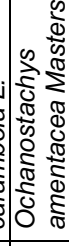 \\
\hline $\begin{array}{l}\bar{\pi} \\
\frac{\pi}{0} \\
\frac{\pi}{\pi} \\
\tilde{\sigma} \\
\frac{\pi}{2}\end{array}$ & 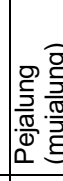 & 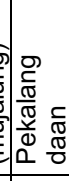 & 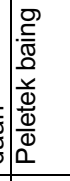 & 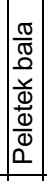 & $\mid \begin{array}{l}0 \\
\frac{0}{0} \\
\frac{7}{0} \\
\frac{1}{0} \\
\frac{1}{0} \\
\frac{0}{0} \\
0\end{array}$ & 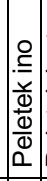 & 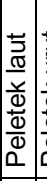 & 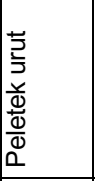 & 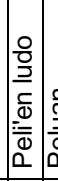 & $\begin{array}{l}\frac{c}{\mathbb{0}} \\
\frac{\partial}{0} \\
0 \\
0\end{array}$ & $\begin{array}{l}\mathbb{0} \\
\frac{\pi}{\tilde{D}} \\
\mathbb{\alpha} \\
\alpha\end{array}$ & $\begin{array}{l}\frac{9}{2} \\
\frac{1}{0} \\
\frac{0}{0} \\
\mathbb{0} \\
0 \\
0 \\
0\end{array}$ & . & $\frac{\pi}{\alpha}$ & 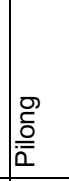 \\
\hline 운 & 占 & 我 & $\hat{\widehat{f}}$ & 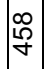 & 多 & 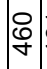 & $\bar{\sigma}$ & & $\ddot{\sigma}$ & O্ & 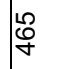 & $\begin{array}{l}\mathscr{O} \\
\mathscr{O} \\
\dot{\sigma}\end{array}$ & $\hat{O}$ & 舟 & \&্ \\
\hline
\end{tabular}




\begin{tabular}{|c|c|c|c|c|c|c|c|c|c|c|c|c|c|c|c|c|}
\hline 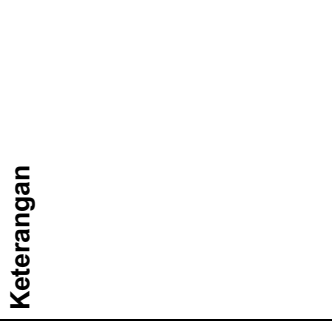 & 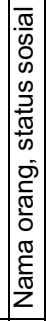 & 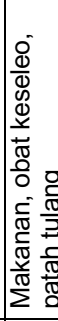 & 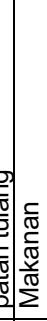 & 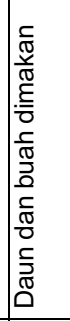 & 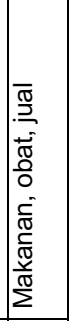 & 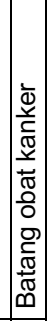 & 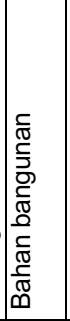 & 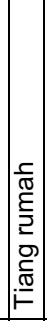 & 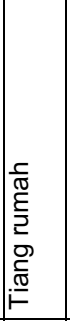 & 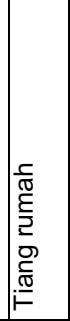 & 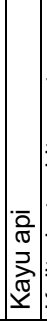 & 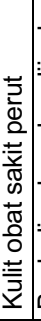 & 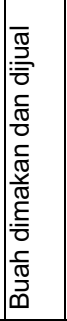 & 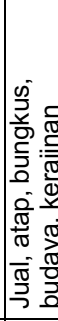 & 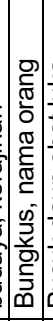 & $\begin{array}{l}\frac{\pi}{0} \\
\frac{3}{3} \\
\frac{\pi}{\pi} \\
\frac{0}{0} \\
\frac{5}{5} \\
\frac{\pi}{0} \\
\frac{1}{3} \\
\frac{0}{2} \\
0 \\
0\end{array}$ \\
\hline Total kegunaan & - & $m$ & - & - & $m$ & - & - & - & - & - & - & - & N & 10 & $m$ & - \\
\hline Dilindungi/mulen & 1 & 1 & ' & 1 & 1 & 1 & 1 & 1 & 1 & ' & ' & 1 & ' & ' & 1 & 1 \\
\hline Status sosial/nama orang & - & - & ' & 1 & ' & 1 & ' & 1 & ' & ' & ' & ' & ' & ' & - & 1 \\
\hline Kerajinan/pewarna & 1 & 1 & ' & 1 & ' & 1 & 1 & ' & ' & ' & ' & ' & ' & - & ' & 1 \\
\hline Upacara/budaya & 1 & , & ' & 1 & ' & 1 & ' & ' & ' & ' & $\cdot$ & 1 & ' & - & . & , \\
\hline Kebutuhan tak langsung & 1 & 1 & ' & 1 & ' & 1 & 1 & 1 & 1 & ' & $\cdot$ & 1 & ' & ' & 1 & 1 \\
\hline Hutan sumber bibit & 1 & 1 & ' & 1 & ' & 1 & 1 & ' & ' & ' & ' & ' & ' & ' & ' & ' \\
\hline Bungkus & 1 & ' & ' & 1 & ' & 1 & I & 1 & 1 & ' & ' & $\cdot$ & ' & - & - & 1 \\
\hline Atap & 1 & 1 & ' & 1 & ' & 1 & ' & 1 & ' & ' & $\cdot$ & 1 & ' & - & ' & ' \\
\hline Bahan pengikat/tali & 1 & 1 & ' & 1 & ' & 1 & 1 & ' & 1 & ' & $\cdot$ & 1 & ' & ' & ' & ' \\
\hline Kayu api & 1 & . & ' & 1 & ' & 1 & ' & ' & I & ' & - & ' & ' & ' & . & 1 \\
\hline Ekonomi & 1 & 1 & ' & 1 & - & 1 & 1 & ' & 1 & ' & ' & $\cdot$ & - & - & ' & 1 \\
\hline Bangunan/perahu & 1 & 1 & ' & 1 & ' & 1 & - & - & - & - & ' & $\cdot$ & 1 & ' & , & ! \\
\hline Obat/racun & ' & - & ' & 1 & - & - & ' & ' & 1 & ' & , & - & 1 & ' & 1 & - \\
\hline Makanan & 1 & - & - & - & - & 1 & 1 & 1 & ' & 1 & $\cdot$ & $\cdot$ & - & 1 & - & 1 \\
\hline Pertanian & 1 & - & ' & - & - & 1 & 1 & 1 & I & ' & ' & $\cdot$ & - & ' & . & 1 \\
\hline Jekkau liar & - & 1 & ' & 1 & ' & 1 & 1 & ' & . & ' & , & - & 1 & ' & . & 1 \\
\hline Hutan rimba & - & 1 & $F$ & 1 & 1 & - & - & - & - & - & - & - & 1 & - & & - \\
\hline Kategori & $\underline{\xi}$ & $\underset{\underline{\underline{z}}}{\underline{\xi}}$ & $\underset{\xi}{\xi}$ & $\underset{\vDash}{\xi}$ & $\underline{\xi}$ & $\underset{f}{\underline{\xi}}$ & $\underset{\wp}{\underline{\xi}}$ & $\underset{\xi}{\Xi}$ & $\underset{\xi}{\underline{\xi}}$ & $\underset{\mapsto}{\xi}$ & $\underset{F}{\underline{\xi}}$ & $\underline{\xi}$ & $\underset{⺊}{\xi}$ & 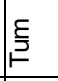 & & $\underline{\xi}$ \\
\hline 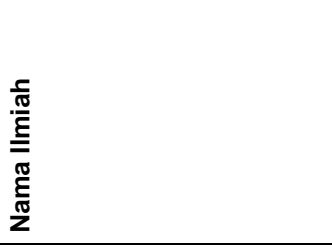 & $\begin{array}{l}\mathbb{D} \\
\mathbb{D} \\
\mathbb{\Xi} \\
\mathbb{\Xi} \\
\mathbb{0} \\
0 \\
\end{array}$ & 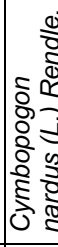 & 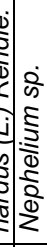 & 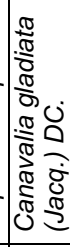 & 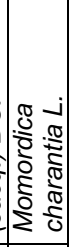 & & 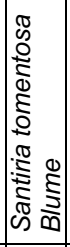 & $\bar{z}$ & $\bar{z}$ & $\bar{z}$ & $\bar{z}$ & $\begin{array}{l}\frac{\pi}{2} \\
\frac{\pi}{2} \\
\frac{\pi}{2} \\
\frac{\pi}{2} \\
\frac{2}{2} \\
\frac{0}{0} \\
\frac{\pi}{0} \\
\end{array}$ & 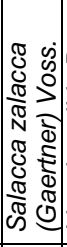 & 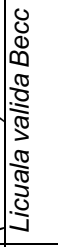 & 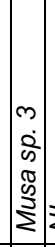 & $\bar{z}$ \\
\hline 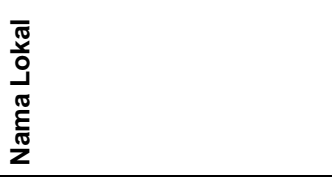 & 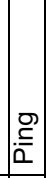 & 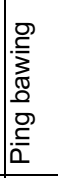 & 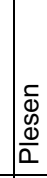 & 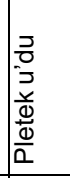 & - & 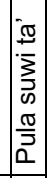 & 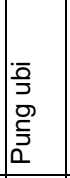 & \begin{tabular}{|c|}
$\frac{\pi}{\pi}$ \\
$\frac{0}{0}$ \\
$\frac{0}{3}$ \\
0 \\
0 \\
$\vdots$ \\
0 \\
0 \\
\end{tabular} & 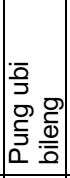 & 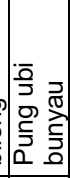 & $\begin{array}{l}0 \\
\stackrel{2}{0} \\
\stackrel{2}{2} \\
\\
2\end{array}$ & $\begin{array}{l}\frac{c}{\Phi} \\
\vec{J} \\
\mathbf{D}\end{array}$ & $\begin{array}{l}\frac{\vec{\sigma}}{\pi} \\
\text { ஸे }\end{array}$ & 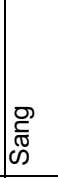 & \begin{tabular}{|c}
0 \\
$\pi$ \\
3 \\
$\infty$ \\
$\infty$ \\
$\infty$
\end{tabular} & $\begin{array}{l}\overrightarrow{\widetilde{\pi}} \\
\frac{0}{\mathbb{N}} \\
\infty \\
\end{array}$ \\
\hline 운 & $\begin{array}{l}R \\
f \\
f\end{array}$ & $\bar{\gamma}$ & 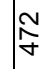 & 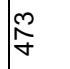 & 尔 & $\begin{array}{l}\infty \\
\stackrel{\gamma}{\sigma}\end{array}$ & $\stackrel{\mathscr{Q}}{\stackrel{2}{f}}$ & $\hat{F}$ & $\stackrel{\infty}{\stackrel{\infty}{f}}$ & 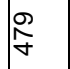 & \begin{tabular}{l}
$\infty$ \\
$\infty$ \\
\multirow{\sigma}{*}{}
\end{tabular} & 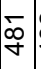 & $\underset{\sim}{\sim}$ & 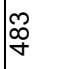 & 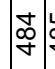 & 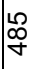 \\
\hline
\end{tabular}




\begin{tabular}{|c|c|c|c|c|c|c|c|c|c|c|c|c|c|}
\hline 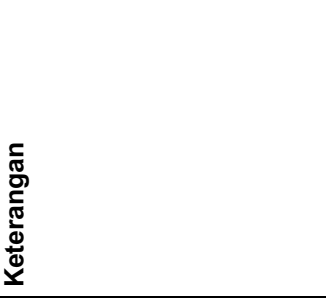 & 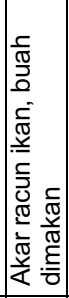 & 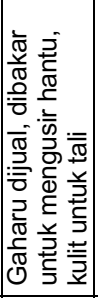 & 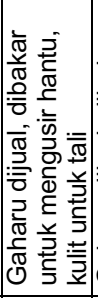 & 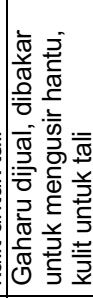 & 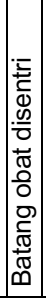 & 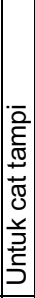 & $\begin{array}{r} \\
+\frac{\pi}{0} \\
0 \\
\end{array}$ & 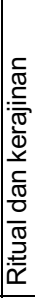 & 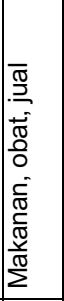 & 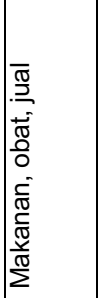 & . & 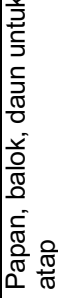 & 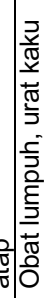 \\
\hline Total kegunaan & N & $\checkmark$ & $\checkmark$ & A & - & - & - & $N$ & $m$ & $m$ & -6 & n & m \\
\hline Dilindungi/mulen & ' & ' & ' & ' & 1 & 1 & 1 & 1 & 1 & ' & ' & ' & 1 \\
\hline Status sosial/nama orang & ' & ' & ' & ' & ' & 1 & 1 & 1 & 1 & ' & ' & 1 & ' \\
\hline Kerajinan/pewarna & ' & ' & 1 & 1 & ' & - & 1 & - & 1 & ' & ' & 1 & ' \\
\hline Upacara/budaya & 1 & - & - & - & ' & . & 1 & - & , & ' & . & 1 & ' \\
\hline Kebutuhan tak langsung & ' & ' & 1 & 1 & 1 & 1 & 1 & 1 & 1 & 1 & 1 & 1 & ' \\
\hline Hutan sumber bibit & ' & ' & ' & ' & ' & 1 & 1 & 1 & ' & ' & . & 1 & ' \\
\hline Bungkus & ' & ' & ' & 1 & ' & 1 & 1 & . & 1 & ' & . & 1 & - \\
\hline Atap & ' & ' & $\cdot$ & 1 & $\cdot$ & 1 & 1 & . & ' & ' & 1. & - & ' \\
\hline Bahan pengikat/tali & ' & - & - & - & ' & ' & 1 & ' & 1 & ' & ' & 1 & ' \\
\hline Kayu api & ' & ' & ' & ' & ' & 1 & ' & 1 & 1 & ' & . & 1 & ' \\
\hline Ekonomi & ' & - & - & - & ' & 1 & 1 & 1 & - & - & ' & 1 & ' \\
\hline Bangunan/perahu & ' & ' & ' & 1 & ' & 1 & 1 & 1 & 1 & ' & 1. & - & ' \\
\hline Obat/racun & - & - & - & - & - & 1 & - & . & - & - & ' & 1 & - \\
\hline Makanan & - & ' & 1 & 1 & ' & 1 & 1 & 1 & - & - & - & 1 & - \\
\hline Pertanian & ' & ' & ' & ' & ' & 1 & 1 & 1 & - & - & ' & 1 & ' \\
\hline Jekkau liar & - & ' & ' & 1 & ' & 1 & - & - & 1 & ' & ' & 1 & - \\
\hline Hutan rimba & - & - & - & - & - & - & 1 & - & 1 & ' & $-\sigma$ & - & ' \\
\hline Kategori & $\underset{\vDash}{\xi}$ & $\mid \underline{\xi}$ & $\underline{\underline{\xi}}$ & $\mid \underline{\xi}$ & $\frac{\varepsilon}{J}$ & $\frac{\varepsilon}{F}$ & $\underline{\Xi}$ & $\frac{\xi}{F}$ & $\mid \underline{\xi}$ & $\mid \underline{\xi}$ & $\frac{E}{J}$ & $\frac{\xi}{\rho}$ & $\frac{\xi}{p}$ \\
\hline $\begin{array}{l}\frac{c}{\frac{\pi}{E}} \\
\frac{\underline{E}}{\bar{\pi}} \\
\frac{\pi}{E} \\
\text { Z } \\
\end{array}$ & 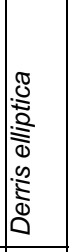 & 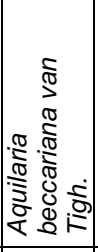 & 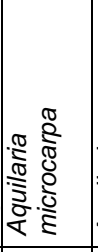 & 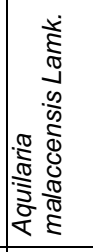 & $\bar{z}$ & 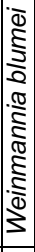 & $\bar{z}$ & 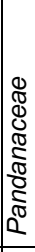 & 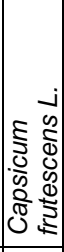 & 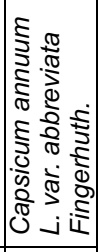 & & 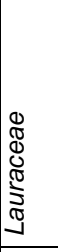 & 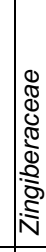 \\
\hline 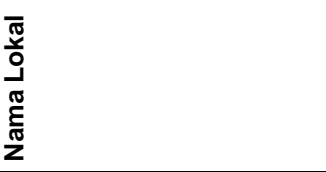 & 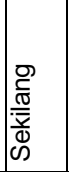 & 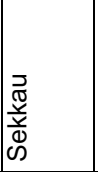 & 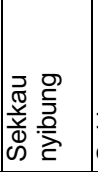 & 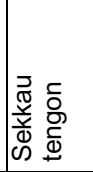 & $\mid \begin{array}{l}0 \\
\frac{0}{3} \\
\frac{0}{2} \\
\overline{3} \\
\frac{2}{0} \\
\frac{\pi}{0} \\
0 \\
\infty\end{array}$ & 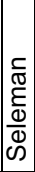 & 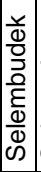 & 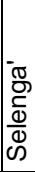 & 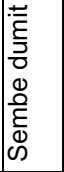 & 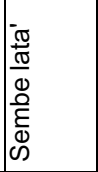 & $\begin{array}{lll} & \\
\stackrel{0}{\infty} & \\
\infty & 0\end{array}$ & 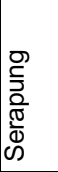 & 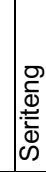 \\
\hline 우 & $\begin{array}{l}\mathscr{Q} \\
\stackrel{\infty}{+}\end{array}$ & 僤 & $\begin{array}{l}\infty \\
\infty \\
\stackrel{\infty}{f}\end{array}$ & 总 & প্ণ & & নু & 多 & 过 & 㔔 & 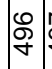 & 字 & $\stackrel{\infty}{\circ}$ \\
\hline
\end{tabular}




\begin{tabular}{|c|c|c|c|c|c|c|c|c|c|c|c|c|c|c|c|}
\hline 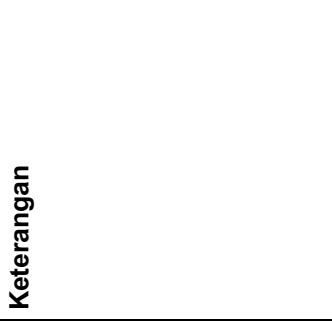 & 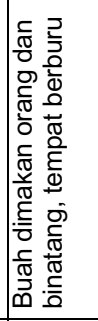 & 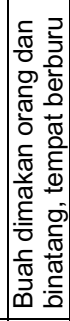 & 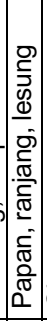 & \begin{tabular}{|l} 
\\
$+\frac{\pi}{0}$ \\
0 \\
\end{tabular} & 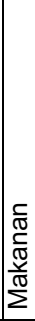 & 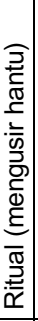 & 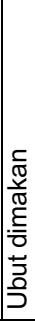 & 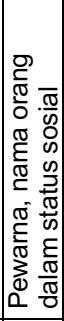 & 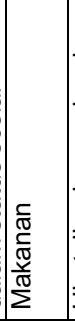 & 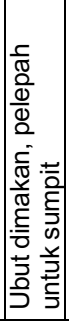 & 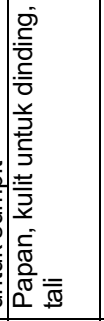 & 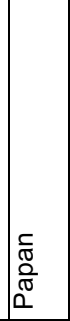 & & 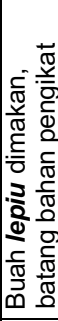 & 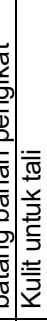 \\
\hline Total kegunaan & N & a & $m$ & - & - & - & - & N & - & N & N & - & $-r$ & N & N \\
\hline Dilindungi/mulen & ' & ' & 1 & 1 & 1 & 1 & 1 & 1 & ' & ' & 1 & 1 & ' & 1 & ' \\
\hline Status sosial/nama orang & 1 & ' & ' & ' & 1 & ' & , & - & ' & ' & ' & 1 & ' & ' & ' \\
\hline Kerajinan/pewarna & ' & ' & - & 1 & 1 & ' & 1 & - & ' & - & - & 1 & ' & 1 & - \\
\hline Upacara/budaya & ' & ' & - & . & . & - & , & ' & ' & ' & ' & ' & . & , & I \\
\hline Kebutuhan tak langsung & - & - & 1 & 1 & 1 & ' & 1 & I & ' & ' & 1 & 1 & 1 & 1 & ' \\
\hline Hutan sumber bibit & ' & ' & 1 & 1 & 1 & ' & 1 & 1 & ' & ' & ' & ' & ' & 1 & 1 \\
\hline Bungkus & ' & ' & 1 & 1 & 1 & 1 & 1 & 1 & ' & ' & ' & 1 & ' & 1 & 1 \\
\hline Atap & ' & ' & 1 & 1 & . & 1 & ' & 1 & ' & ' & ' & ' & 1 & 1 & 1 \\
\hline Bahan pengikat/tali & ' & ' & ' & 1 & 1 & ' & 1 & 1 & ' & ' & 1 & ' & ' & - & - \\
\hline Kayu api & ' & ' & 1 & 1 & 1 & I & 1 & I & ' & ' & ' & 1 & - & 1 & ' \\
\hline Ekonomi & ' & ' & 1 & 1 & 1 & 1 & 1 & 1 & ' & ' & ' & 1 & ' & ' & ' \\
\hline Bangunan/perahu & ' & ' & - & 1 & 1 & 1 & 1 & I & ' & ' & - & - & ' & 1 & ' \\
\hline Obat/racun & 1 & ' & 1 & - & . & 1 & , & ' & ' & ' & 1 & 1 & ' & 1 & ' \\
\hline Makanan & - & - & 1 & 1 & - & ' & - & 1 & - & - & 1 & 1 & 1. & - & ' \\
\hline Pertanian & 1 & ' & ' & 1 & 1 & 1 & 1 & 1 & - & 1 & 1 & 1 & 1 & 1 & ' \\
\hline Jekkau liar & ' & ' & . & 1 & 1 & 1 & - & I & ' & ' & 1 & 1 & ' & 1 & ' \\
\hline Hutan rimba & - & - & - & - & - & 1 & $F$ & - & 1 & - & - & - & $-\sigma$ & - & $F$ \\
\hline Kategori & $\underline{\xi}$ & $\frac{\varepsilon}{\xi}$ & $\frac{\varepsilon}{5}$ & $\frac{\xi}{F}$ & $\frac{\varepsilon}{F}$ & $\frac{E}{5}$ & $\frac{\varepsilon}{F}$ & $\mid \underline{\xi}$ & $\underline{\xi}$ & $\underline{\xi}$ & $\underline{\xi}$ & $\underline{\xi}$ & & $\underset{\xi}{\xi}$ & $\underline{\xi}$ \\
\hline 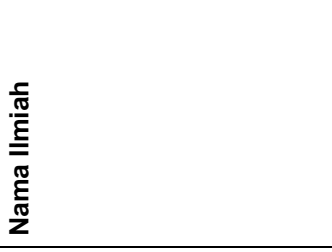 & 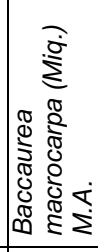 & 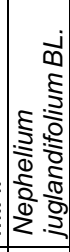 & & $\bar{z}$ & & $\bar{z}$ & 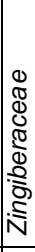 & 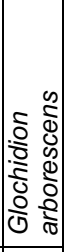 & 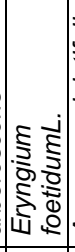 & 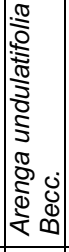 & 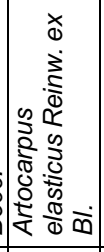 & 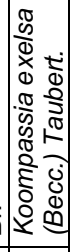 & & 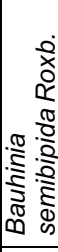 & 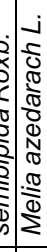 \\
\hline 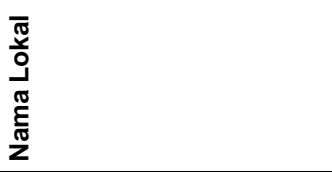 & $\begin{array}{l}\bar{\sigma} \\
\stackrel{5}{ \pm} \\
\infty\end{array}$ & 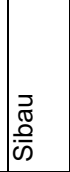 & 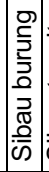 & 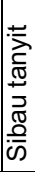 & $\frac{\frac{\varepsilon}{\omega}}{\bar{\omega}}$ & 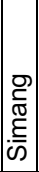 & कू & 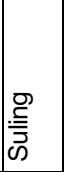 & $\stackrel{\circ}{\circ}$ & 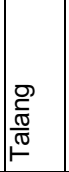 & 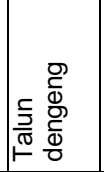 & 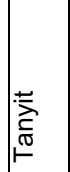 & 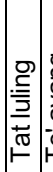 & 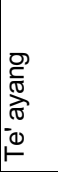 & 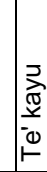 \\
\hline 을 & 多 & 通 & i & & & t & & مי & î & 冓 & is & $\frac{0}{15}$ & is & $\frac{\mathfrak{N}}{5}$ & $\frac{m}{i s}$ \\
\hline
\end{tabular}




\begin{tabular}{|c|c|c|c|c|c|c|c|c|c|c|c|c|c|c|}
\hline 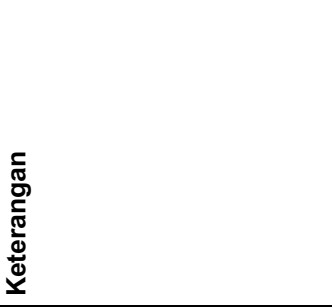 & 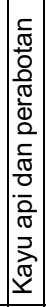 & 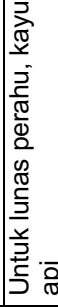 & 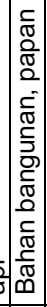 & 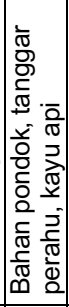 & 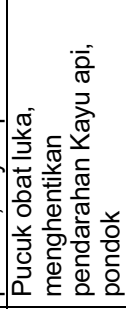 & 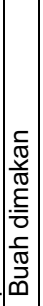 & 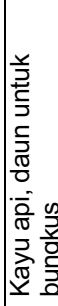 & $\frac{\mid}{\bar{a}}$ & 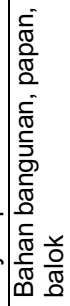 & 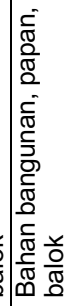 & 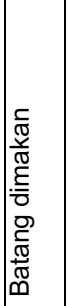 & 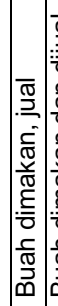 & 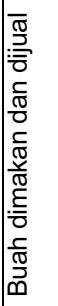 & 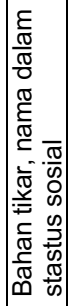 \\
\hline Total kegunaan & $\sim$ & N & - & N & a & N & N & - & - & - & - & a & N & N \\
\hline Dilindungi/mulen & 1 & 1 & 1 & 1 & 1 & 1 & 1 & 1 & ' & ' & ' & 1 & 1 & ' \\
\hline Status sosial/nama orang & 1 & 1 & 1 & 1 & 1 & 1 & ' & ' & 1 & ' & ' & 1 & 1 & - \\
\hline Kerajinan/pewarna & - & 1 & 1 & 1 & 1 & 1 & ' & ' & 1 & ' & ' & 1 & 1 & - \\
\hline Upacara/budaya & 1 & , & 1 & , & . & - & , & ' & 1 & ' & ' & . & , & 1 \\
\hline Kebutuhan tak langsung & 1 & 1 & 1 & 1 & 1 & 1 & 1 & ' & 1 & ' & ' & 1 & 1 & 1 \\
\hline Hutan sumber bibit & 1 & 1 & ' & 1 & 1 & 1 & 1 & ' & 1 & ' & ' & 1 & 1 & ' \\
\hline Bungkus & ' & 1 & ' & 1 & ' & 1 & - & 1 & 1 & ' & ' & . & 1 & ' \\
\hline Atap & 1 & 1 & 1 & 1 & 1 & 1 & ' & 1 & 1 & ' & $\cdot$ & 1 & 1 & ' \\
\hline Bahan pengikat/tali & 1 & 1 & 1 & 1 & ' & 1 & 1 & 1 & 1 & ' & ' & 1 & 1 & ' \\
\hline Kayu api & - & - & 1 & - & - & 1 & - & - & 1 & ' & ' & . & 1 & 1 \\
\hline Ekonomi & 1 & 1 & 1 & 1 & 1 & 1 & 1 & ' & 1 & ' & ' & $-\gamma$ & - & 1 \\
\hline Bangunan/perahu & ' & - & - & - & 1 & 1 & 1 & ' & - & - & ' & . & I & ' \\
\hline Obat/racun & 1 & 1 & 1 & ' & - & ' & I & ' & 1 & ' & ' & ' & ' & 1 \\
\hline Makanan & 1 & 1 & 1 & 1 & 1 & - & 1 & 1 & 1 & ' & - & - & - & 1 \\
\hline Pertanian & 1 & 1 & 1 & 1 & 1 & 1 & 1 & 1 & 1 & ' & $r$ & - & - & ' \\
\hline Jekkau liar & 1 & 1 & 1 & 1 & - & - & - & - & 1 & ' & ' & ' & 1 & ' \\
\hline Hutan rimba & - & - & - & - & - & - & - & - & $F$ & - & ' & 1 & 1 & - \\
\hline Kategori & $\underset{\xi}{\xi}$ & 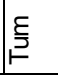 & $\underset{\xi}{\xi}$ & $\underline{\xi}$ & $\frac{\varepsilon}{F}$ & 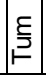 & $\underline{\xi}$ & $\underset{\xi}{\xi}$ & $\underset{\vDash}{\xi}$ & $\underset{\xi}{\xi}$ & $\stackrel{\xi}{\xi}$ & $\underset{F}{\xi}$ & $\underset{\vdash}{\xi}$ & $\underset{\not}{\underline{F}}$ \\
\hline 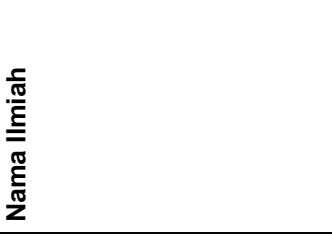 & $\begin{array}{l}0 \\
0 \\
2 \\
\frac{9}{3} \\
\frac{1}{8} \\
\frac{1}{2} \\
\frac{1}{0} \\
0 \\
\frac{1}{1} \\
\frac{1}{4} \\
\end{array}$ & 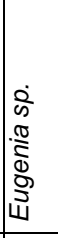 & $\bar{z}$ & 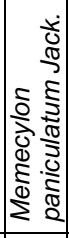 & 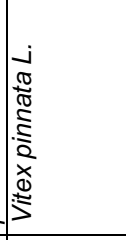 & 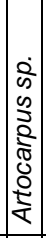 & 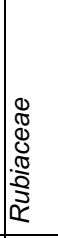 & 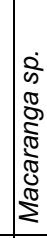 & 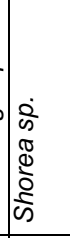 & $\bar{z}$ & 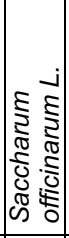 & 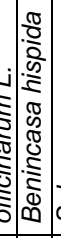 & 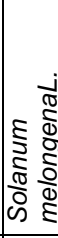 & $\left\{\begin{array}{l}\frac{2}{2} \\
\frac{5}{2} \\
\frac{2}{\infty} \\
\frac{2}{3}\end{array}\right.$ \\
\hline 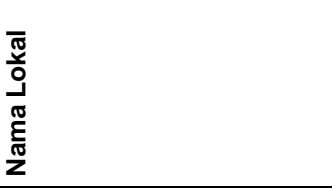 & 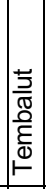 & $\frac{\text { 을 }}{\frac{0}{0}}$ & 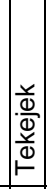 & 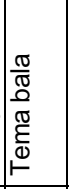 & 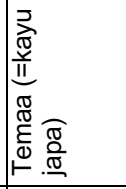 & 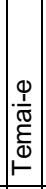 & 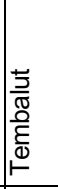 & 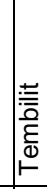 & 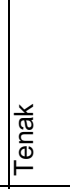 & 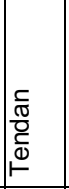 & $\frac{\overrightarrow{2}}{\frac{0}{2}}$ & 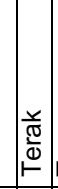 & 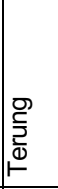 & 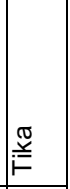 \\
\hline 울 & $\frac{7}{i n}$ & $\frac{10}{10}$ & $\frac{0}{i n}$ & $\frac{1}{i n}$ & $\frac{\infty}{i n}$ & $\frac{0}{15}$ & 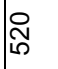 & i্ & స్ & స్ & ĩ & $\begin{array}{l}\mathcal{L} \\
\tilde{N}\end{array}$ & ڤ్ & స్ \\
\hline
\end{tabular}




\begin{tabular}{|c|c|c|c|c|c|c|c|c|c|c|c|c|c|c|}
\hline 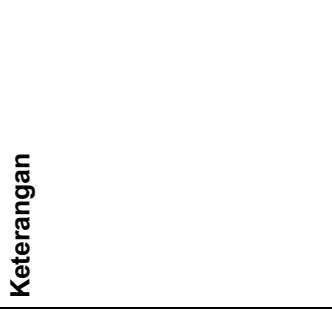 & 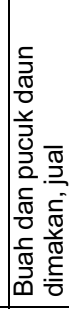 & 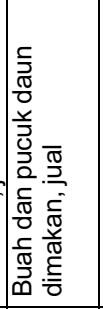 & 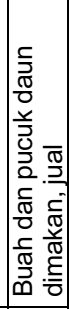 & 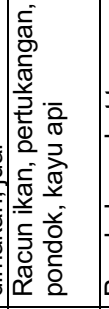 & 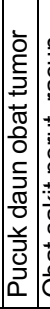 & 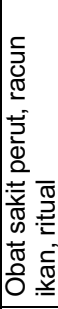 & 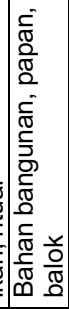 & 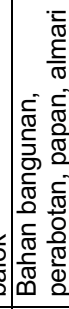 & 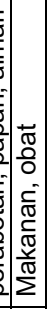 & 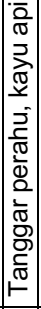 & 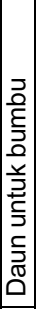 & 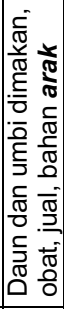 & 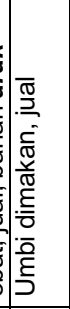 & 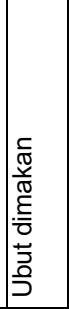 \\
\hline Total kegunaan & N & N & $\sim$ & $m$ & $-\sigma$ & N & - & - & $\sim$ & $\sim$ & - & $\theta$ & N & - \\
\hline Dilindungi/mulen & ' & 1 & 1 & 1 & 1 & & 1 & 1 & 1 & 1 & 1 & 1 & ' & 1 \\
\hline Status sosial/nama orang & 1 & 1 & ' & 1 & 1 & & 1 & ' & 1 & 1 & 1 & 1 & ' & 1 \\
\hline Kerajinan/pewarna & ' & ' & 1 & 1 & 1 & & 1 & ' & 1 & 1 & 1 & ' & ' & 1 \\
\hline Upacara/budaya & ' & ' & , & . & 1. & - & 1 & ' & 1 & , & 1 & - & ' & ' \\
\hline Kebutuhan tak langsung & 1 & ' & 1 & 1 & 1 & & 1 & 1 & 1 & 1 & 1 & ' & 1 & 1 \\
\hline Hutan sumber bibit & 1 & 1 & 1 & 1 & ' & & 1 & ' & 1 & 1 & 1 & 1 & 1 & 1 \\
\hline Bungkus & 1 & 1 & 1 & 1 & 1 & & 1 & 1 & 1 & . & 1 & 1 & 1 & ' \\
\hline Atap & 1 & 1 & 1 & 1 & 1 & & 1 & ' & 1 & 1 & . & 1 & 1 & 1 \\
\hline Bahan pengikat/tali & 1 & ' & 1 & 1 & 1 & & 1 & ' & ' & 1 & I & 1 & 1 & ' \\
\hline Kayu api & 1 & 1 & 1 & - & ' & & 1 & ' & 1 & - & 1 & 1 & 1 & ' \\
\hline Ekonomi & - & - & - & 1 & 1 & & 1 & 1 & 1 & 1 & 1 & - & - & 1 \\
\hline Bangunan/perahu & 1 & 1 & 1 & - & ' & & - & - & 1 & - & 1 & ' & 1 & 1 \\
\hline Obat/racun & 1 & 1 & 1 & - & -5 & - & ' & 1 & - & . & 1 & - & 1 & 1 \\
\hline Makanan & - & - & - & 1 & 1 & & 1 & 1 & - & 1 & - & - & - & - \\
\hline Pertanian & - & - & - & 1 & 1 & & 1 & 1 & 1 & 1 & 1 & - & - & 1 \\
\hline Jekkau liar & 1 & ' & ' & 1 & 1 & & 1 & 1 & 1 & 1 & . & 1 & 1 & - \\
\hline Hutan rimba & 1 & 1 & 1 & - & $-\sigma$ & - & - & - & - & - & - & 1 & ' & 1 \\
\hline Kategori & $\varliminf_{\vdash}^{\xi}$ & $\underset{\vDash}{\xi}$ & $\mid \underline{\xi}$ & $\underset{\vDash}{\xi}$ & $\underset{F}{\xi}$ & $\underset{\xi}{\xi}$ & $\underset{\vdash}{\xi}$ & $\stackrel{\xi}{\xi}$ & $\frac{\varepsilon}{\xi}$ & $\frac{\varepsilon}{5}$ & $\underline{\underline{F}}$ & $\underset{\mathfrak{F}}{\underline{\underline{V}}}$ & $\underset{\not}{\underline{\xi}}$ & $\underset{\xi}{\xi}$ \\
\hline 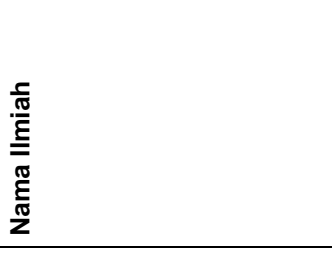 & 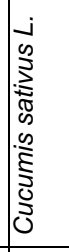 & 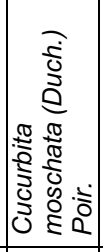 & 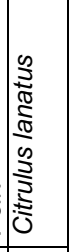 & 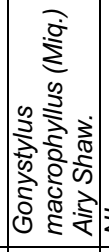 & & $\begin{array}{l}\frac{1}{0} \\
\infty \\
\frac{0}{10} \\
0 \\
0\end{array}$ & $\bar{z}$ & 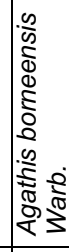 & 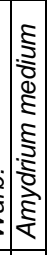 & 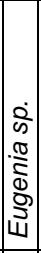 & 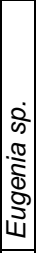 & 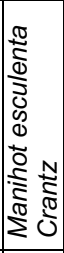 & 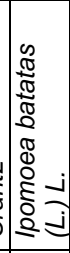 & 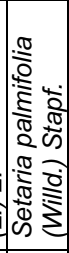 \\
\hline 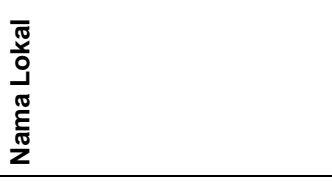 & 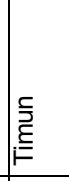 & 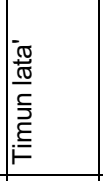 & 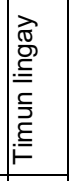 & 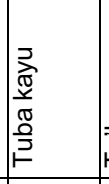 & 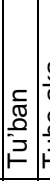 & 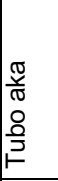 & 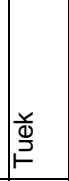 & $\underset{\mathfrak{F}}{\overrightarrow{\mathfrak{g}}}$ & 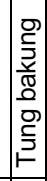 & $\frac{\pi}{\stackrel{\Omega}{د}}$ & & 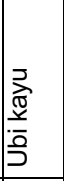 & 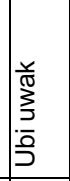 & 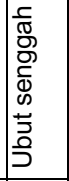 \\
\hline 운 & $\begin{array}{l}\infty \\
\tilde{N} \\
i n\end{array}$ & 跑 & 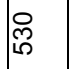 & 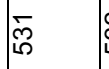 & 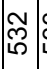 & ల్లె & స్లి & 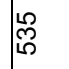 & $\begin{array}{l}0 \\
\tilde{N} \\
\text { in }\end{array}$ & & & గ్లి & 守 & 氐 \\
\hline
\end{tabular}




\begin{tabular}{|c|c|c|c|c|c|c|c|c|c|c|c|c|c|c|c|}
\hline 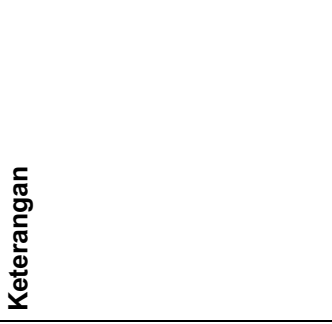 & 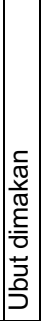 & 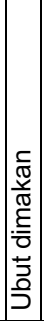 & 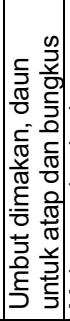 & 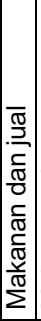 & 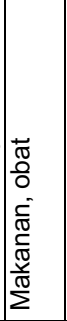 & 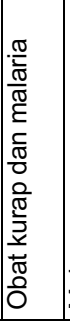 & 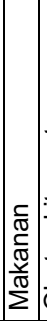 & 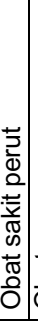 & $\begin{array}{l} \\
\mathbb{\pi} \\
0 \\
0\end{array}$ & 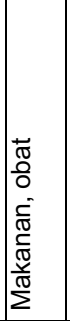 & 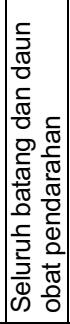 & 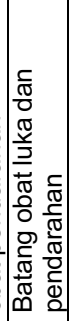 & 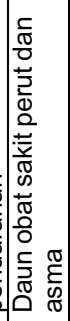 & 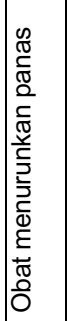 & 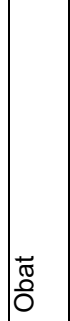 \\
\hline Total kegunaan & - & - & $m$ & $\sim$ & $\sim$ & - & - & - & - & N & N & - & N & - & - \\
\hline Dilindungi/mulen & ' & 1 & 1 & 1 & 1 & ' & 1 & ' & ' & ' & ' & ' & ' & ' & ' \\
\hline Status sosial/nama orang & 1 & 1 & I & ' & 1 & ' & ' & ' & ' & ' & ' & ' & ' & ' & ' \\
\hline Kerajinan/pewarna & ' & 1 & 1 & 1 & 1 & ' & 1 & ' & ' & ' & ' & 1 & ' & ' & ' \\
\hline Upacara/budaya & 1 & 1 & , & 1 & ' & ' & ' & . & ' & 1 & - & ' & ' & ' & ' \\
\hline Kebutuhan tak langsung & 1 & 1 & 1 & $\cdot$ & 1 & ' & ' & $\cdot$ & ' & ' & ' & ' & ' & ' & ' \\
\hline Hutan sumber bibit & 1 & 1 & . & 1 & ' & ' & 1 & 1 & ' & ' & ' & ' & ' & ' & ' \\
\hline Bungkus & ' & ' & - & ' & 1 & ' & . & 1 & 1 & ' & ' & ' & ' & ' & ' \\
\hline Atap & ' & $\cdot$ & - & ' & ' & 1 & ' & 1 & 1 & 1 & 1 & ' & ' & ' & ' \\
\hline Bahan pengikat/tali & 1 & 1 & 1 & ' & ' & ' & ' & 1 & 1 & ' & ' & ' & ' & ' & ' \\
\hline Kayu api & ' & 1 & 1 & ' & 1 & ' & ' & 1 & 1 & ' & 1 & ' & ' & ' & ' \\
\hline Ekonomi & 1 & 1 & . & - & 1 & ' & 1 & ' & 1 & ' & ' & ' & ' & ' & ' \\
\hline Bangunan/perahu & 1 & 1 & 1 & 1 & 1 & ' & 1 & 1 & ' & ' & ' & ' & ' & ' & ' \\
\hline Obat/racun & 1 & 1 & 1 & 1 & - & - & 1. & - & - & - & - & - & - & - & - \\
\hline Makanan & - & - & - & - & - & 1 & - & $\cdot$ & 1 & - & ' & 1 & - & 1 & $\cdot$ \\
\hline Pertanian & 1 & 1 & ' & - & 1 & ' & - & $\cdot$ & 1 & 1 & 1 & ' & - & ' & - \\
\hline Jekkau liar & - & - & 1 & - & - & $F$ & 1 & 1 & - & - & - & - & ' & ' & 1 \\
\hline Hutan rimba & 1 & 1 & - & 1 & 1 & - & 1 & - & 1 & ' & 1 & ' & ' & - & ' \\
\hline Kategori & $\underline{\xi}$ & $\underset{\vDash}{\xi}$ & $\underline{\xi}$ & $\xi_{\vdash}^{\varepsilon}$ & $\underline{\varepsilon}$ & $\underline{\xi}$ & $\frac{\varepsilon}{\equiv}$ & $\underline{\xi}$ & $\xi_{\models}^{\xi}$ & $\underset{\vDash}{\xi}$ & $\underline{\xi}$ & $\xi$ & $\xi$ & $\underline{\xi}$ & $\underline{\xi}$ \\
\hline 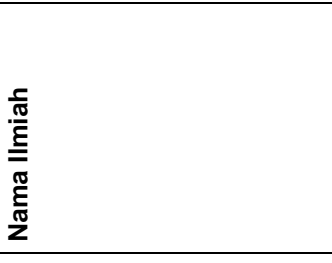 & 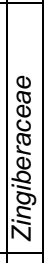 & 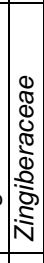 & 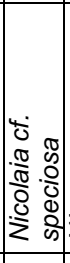 & & 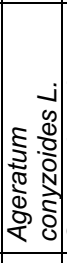 & 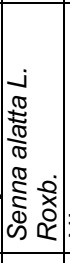 & & $\sum$ & 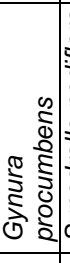 & 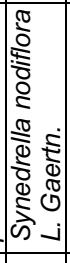 & 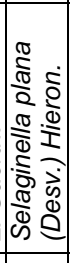 & & $\bar{z}$ & 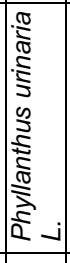 & 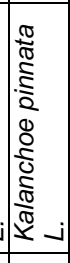 \\
\hline $\begin{array}{l}\bar{\pi} \\
\frac{\pi}{0} \\
\frac{1}{\pi} \\
\stackrel{\mathbb{\pi}}{\pi} \\
\text { Z }\end{array}$ & 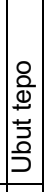 & 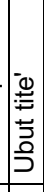 & 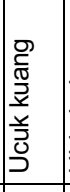 & 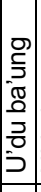 & 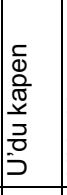 & $\begin{array}{l}\frac{0}{x} \\
\frac{\partial}{\partial} \\
\partial \\
\end{array}$ & . & 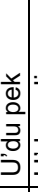 & 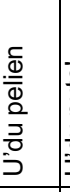 & 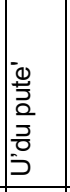 & 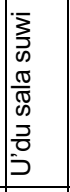 & 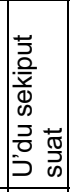 & 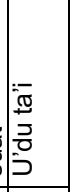 & 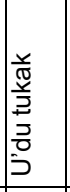 & 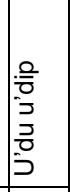 \\
\hline 울 & ₹ & & 离 & & \begin{tabular}{l}
0 \\
\multirow{2}{*}{}
\end{tabular} & 管 & $\left|\begin{array}{l}\infty \\
\vdots \\
1\end{array}\right|$ & & 号 & $\overline{10}$ & స్ & 軟 & 诺 & 占 & 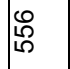 \\
\hline
\end{tabular}




\begin{tabular}{|c|c|c|c|c|c|c|c|c|c|c|c|c|}
\hline 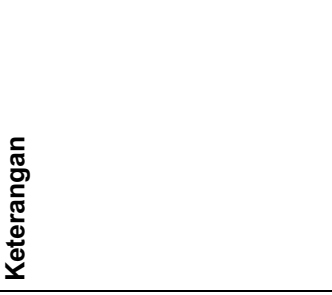 & 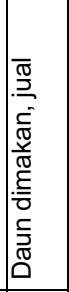 & 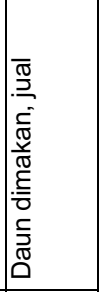 & 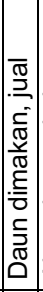 & 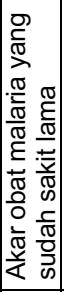 & 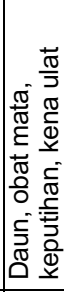 & 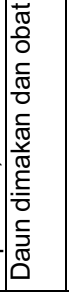 & 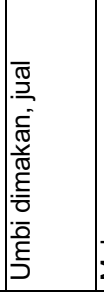 & 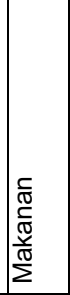 & 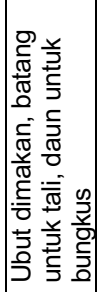 & 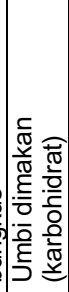 & 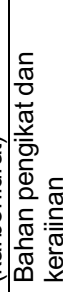 & 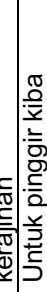 \\
\hline Total kegunaan & N & N & - & $m$ & - & N & N & - & $m$ & N & N & N \\
\hline Dilindungi/mulen & ' & ' & 1 & 1 & ' & ' & ' & ' & ' & ' & ' & ' \\
\hline Status sosial/nama orang & ' & ' & 1 & - & ' & ' & ' & ' & ' & ' & ' & ' \\
\hline Kerajinan/pewarna & ' & ' & 1 & 1 & ' & ' & ' & ' & ' & ' & - & $F$ \\
\hline Upacara/budaya & ' & ' & 1 & 1 & ' & ' & ' & ' & ' & ' & ' & , \\
\hline Kebutuhan tak langsung & ' & ' & 1 & 1 & 1 & ' & ' & 1 & 1 & 1 & 1 & ' \\
\hline Hutan sumber bibit & ' & ' & 1 & 1 & ' & ' & ' & ' & ' & ' & ' & ' \\
\hline Bungkus & ' & ' & 1 & 1 & ' & ' & ' & ' & - & ' & ' & ' \\
\hline Atap & ' & ' & 1 & 1 & ' & ' & ' & ' & ' & ' & ' & ' \\
\hline Bahan pengikat/tali & ' & ' & 1 & 1 & ' & ' & ' & ' & - & 1 & - & - \\
\hline Kayu api & ' & ' & 1 & 1 & ' & ' & ' & ' & ' & ' & ' & ' \\
\hline Ekonomi & - & - & 1 & 1 & ' & ' & - & ' & ' & ' & ' & ' \\
\hline Bangunan/perahu & ' & ' & 1 & 1 & 1 & ' & ' & ' & ' & ' & 1 & 1 \\
\hline Obat/racun & ' & 1 & 1 & - & - & - & 1 & ' & ' & - & ' & 1 \\
\hline Makanan & - & - & - & - & 1 & - & - & - & - & - & 1 & ' \\
\hline Pertanian & - & - & - & 1 & ' & 1 & - & - & 1 & ' & ' & ' \\
\hline Jekkau liar & ' & 1 & 1 & - & 1 & - & 1 & ' & - & - & ' & ' \\
\hline Hutan rimba & 1 & 1 & 1 & $F$ & 1 & - & 1 & ' & - & - & - & - \\
\hline Kategori & $\sum_{F}^{\xi}$ & $\underset{\vDash}{\varepsilon}$ & $\frac{\varepsilon}{F}$ & $\frac{\varepsilon}{F}$ & $\frac{\xi}{\rho}$ & $\xi_{\models}^{\xi}$ & $\xi_{\vdash}^{\xi}$ & $\underset{\vDash}{\xi}$ & $\underset{\vDash}{\xi}$ & $\frac{\varepsilon}{\xi}$ & $\mid \underline{\xi}$ & $\underset{f}{\underline{\xi}}$ \\
\hline $\begin{array}{l}\frac{c}{\pi} \\
\frac{.0}{E} \\
\frac{\pi}{E} \\
\frac{\pi}{Z} \\
\end{array}$ & 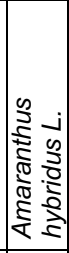 & 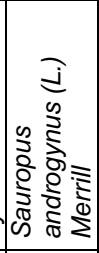 & 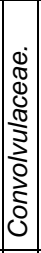 & 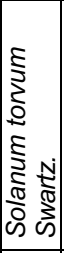 & 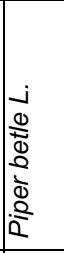 & 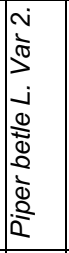 & 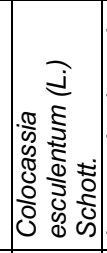 & 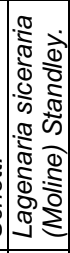 & $\begin{array}{l}2 \\
2 \\
0 \\
0 \\
0 \\
0 \\
0 \\
2 \\
2\end{array}$ & 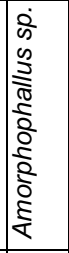 & $\bar{z}$ & $\bar{z}$ \\
\hline 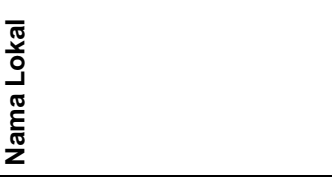 & 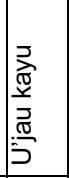 & 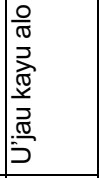 & 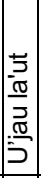 & $\frac{\varepsilon}{\rho}$ & $\begin{array}{l}\frac{5}{\sqrt{0}} \\
\frac{\mathfrak{D}}{5}\end{array}$ & 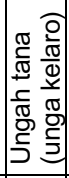 & 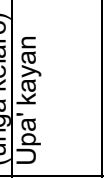 & $\begin{array}{l}\frac{0}{2} \\
\frac{2}{2} \\
\frac{1}{5}\end{array}$ & 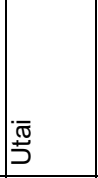 & 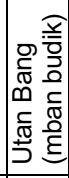 & 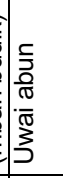 & 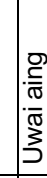 \\
\hline 을 & 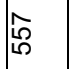 & 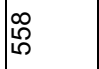 & 吕 & 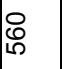 & $\bar{\infty}$ & ్ָ & 勇 & రి & $\mid$ & $\begin{array}{l}\qquad \\
0 \\
i n\end{array}$ & $\hat{\imath}$ & $\mid$ \\
\hline
\end{tabular}




\begin{tabular}{|c|c|c|c|c|c|c|c|c|c|c|c|c|c|c|c|c|}
\hline 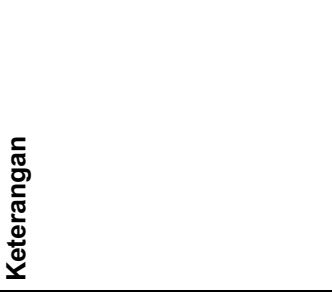 & 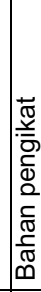 & 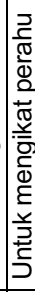 & 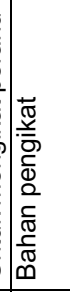 & 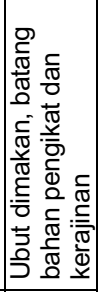 & 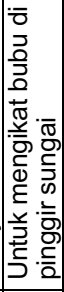 & 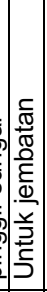 & 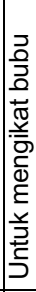 & 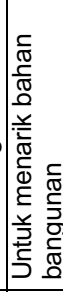 & 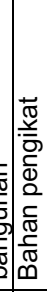 & 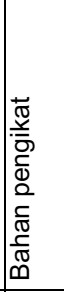 & 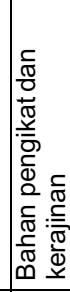 & 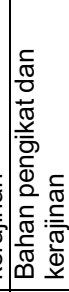 & 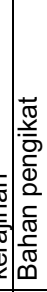 & 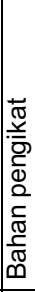 & & 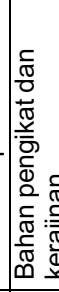 \\
\hline Total kegunaan & - & - & - & $m$ & - & - & - & - & - & - & N & $\theta$ & - & - & - & $m$ \\
\hline Dilindungi/mulen & ' & ' & 1 & 1 & ' & 1 & I & 1 & 1 & 1 & ' & ' & ' & 1 & 1 & 1 \\
\hline Status sosial/nama orang & ' & ' & 1 & 1 & ' & ' & 1 & 1 & 1 & 1 & 1 & ' & ' & 1 & 1 & 1 \\
\hline Kerajinan/pewarna & ' & ' & 1 & - & ' & 1 & 1 & 1 & 1 & 1 & - & - & 1 & ' & 1 & - \\
\hline Upacara/budaya & ' & ' & , & ' & ' & 1 & , & 1 & ' & , & 1 & ' & ' & ' & ' & $F$ \\
\hline Kebutuhan tak langsung & ' & ' & 1 & 1 & ' & 1 & 1 & 1 & 1 & 1 & 1 & ' & 1 & ' & 1 & 1 \\
\hline Hutan sumber bibit & ' & ' & 1 & 1 & ' & 1 & ' & 1 & ' & 1 & 1 & ' & 1 & ' & 1 & 1 \\
\hline Bungkus & ' & ' & I & ' & ' & 1 & . & 1 & ' & . & ' & ' & ' & 1 & ' & 1 \\
\hline Atap & ' & 1 & 1 & 1 & 1 & 1 & . & 1 & 1 & 1 & 1 & ' & ' & ' & 1 & 1 \\
\hline Bahan pengikat/tali & - & - & - & - & - & - & - & - & - & - & - & - & - & - & - & - \\
\hline Kayu api & ' & ' & I & ' & ' & ' & 1 & 1 & ' & 1 & ' & ' & 1 & ' & 1 & 1 \\
\hline Ekonomi & ' & ' & 1 & 1 & ' & 1 & . & 1 & ' & 1 & 1 & 1 & 1 & ' & 1 & 1 \\
\hline Bangunan/perahu & ' & 1 & 1 & 1 & ' & ' & . & 1 & 1 & 1 & ' & ' & ' & . & 1 & 1 \\
\hline Obat/racun & ' & ' & I & ' & ' & ' & . & ' & ' & I & 1 & - & ' & ' & ' & 1 \\
\hline Makanan & ' & ' & 1 & - & 1 & 1 & ' & 1 & 1 & 1 & 1 & - & 1 & 1 & 1 & 1 \\
\hline Pertanian & I & ' & 1 & ' & 1 & 1 & I & 1 & 1 & 1 & 1 & 1 & 1 & ' & 1 & 1 \\
\hline Jekkau liar & ' & 1 & 1 & 1 & ' & 1 & 1 & 1 & 1 & 1 & 1 & 1 & 1 & 1 & 1 & 1 \\
\hline Hutan rimba & - & F & - & - & - & - & $F$ & - & $F$ & - & - & - & - & - & - & - \\
\hline Kategori & $\frac{\varepsilon}{p}$ & $\underset{\xi}{\xi}$ & $\underset{\vDash}{\xi}$ & $\underset{\vDash}{\xi}$ & $\underline{\xi}$ & $\underset{\xi}{\underline{\xi}}$ & $\underline{\xi}$ & $\underset{\vDash}{\xi}$ & $\underset{\vDash}{\xi}$ & $\underset{\xi}{\xi}$ & $\underset{\vDash}{\xi}$ & $\sum_{\models}^{\xi}$ & $\underset{\vDash}{\xi}$ & $\underset{\xi}{\xi}$ & & $\underset{\vDash}{\xi}$ \\
\hline 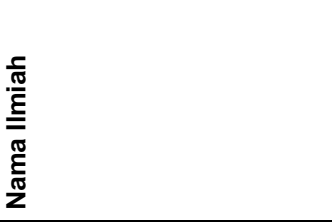 & $\bar{z}$ & $\bar{z}$ & $\bar{z}$ & 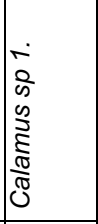 & $\bar{z}$ & $\bar{z}$ & $\bar{z}$ & $\bar{z}$ & $\bar{z}$ & $\bar{z}$ & $\bar{z}$ & 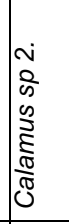 & $\bar{z}$ & & & 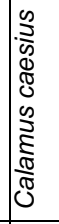 \\
\hline 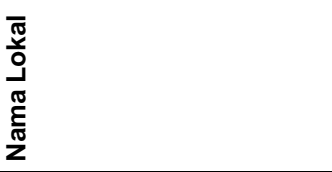 & 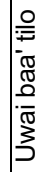 & $\begin{array}{l}\frac{\pi}{\pi} \\
\frac{\pi}{\pi} \\
\frac{\pi}{\pi} \\
3 \\
3\end{array}$ & 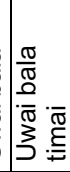 & ه & 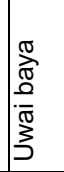 & 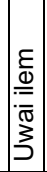 & 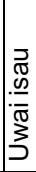 & 㐫 & 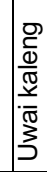 & 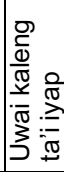 & : & 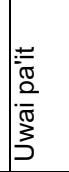 & $\begin{array}{l}\frac{7}{3} \\
\frac{\bar{z}}{2} \\
\frac{\pi}{\pi} \\
\frac{\pi}{3}\end{array}$ & 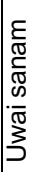 & 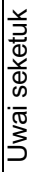 & 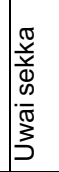 \\
\hline 을 & : & & $\bar{i}$ & 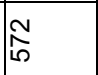 & 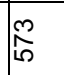 & 出 & 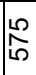 & $\frac{0}{10}$ & in & 象 & $\begin{array}{l}0 \\
\text { in } \\
0\end{array}$ & $\begin{array}{l}\infty \\
\infty \\
i 0\end{array}$ & 隹 & $\underset{\substack{\infty \\
\infty \\
\infty}}{\mathbb{N}}$ & 放 & 犃 \\
\hline
\end{tabular}




\begin{tabular}{|c|c|c|c|c|c|c|c|}
\hline 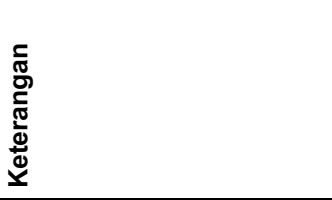 & 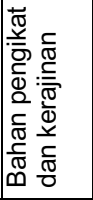 & 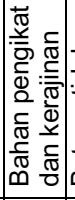 & 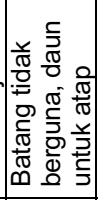 & 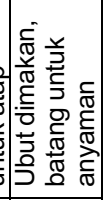 & 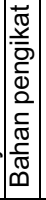 & & \\
\hline Total kegunaan & m & $m$ & - & $m$ & - & h & $\stackrel{\cong}{\cong}$ \\
\hline Dilindungi/mulen & ' & ' & ' & , & . & $\stackrel{\circ}{\circ}$ & $\stackrel{2}{\sim}$ \\
\hline Status sosial/nama orang & ' & ' & ' & 1 & ': & $\stackrel{m}{\square}$ & $\stackrel{\sim}{\sim}$ \\
\hline Kerajinan/pewarna & - & - & ' & - & ' & 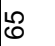 & $\hat{N}$ \\
\hline Upacara/budaya & - & - & ' & - & ' & $\hat{f}$ & 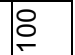 \\
\hline Kebutuhan tak langsung & ' & ' & ' & 1 & $\cdot$ & $\stackrel{\sim}{N}$ & প্ল \\
\hline Hutan sumber bibit & 1 & 1 & ' & 1 & 1 & $\stackrel{\leftrightarrow}{N}$ & $\bar{m}$ \\
\hline Bungkus & ' & ' & ' & ' & $\cdot$ & $\stackrel{\infty}{\sim}$ & $\stackrel{\infty}{-}$ \\
\hline Atap & ' & ' & - & 1 & $\cdot$ & $\neq$ & $\underset{2}{2}$ \\
\hline Bahan pengikat/tali & - & - & ' & ' & - & Lf & \& \\
\hline Kayu api & 1 & 1 & 1 & 1 & 1 & g & g \\
\hline Ekonomi & ' & ' & ' & ' & . & 咅 & 읃 \\
\hline Bangunan/perahu & ' & ' & ' & ' & ' & $\infty$ & $\infty$ \\
\hline Obat/racun & ' & ' & ' & 1 & . & $\stackrel{\mathbb{N}}{\leftarrow}$ & $\stackrel{N}{\Sigma}$ \\
\hline Makanan & ' & ' & ' & - & . & $\stackrel{\mathscr{N}}{\stackrel{2}{\sim}}$ & ల్లి \\
\hline Pertanian & ' & ' & ' & ' & 1 & $\bigoplus$ & $\mathscr{8}$ \\
\hline Jekkau liar & ' & ' & ' & ' & ' & $\bar{\sigma}$ & क人 \\
\hline Hutan rimba & - & - & - & - & - & $\underset{\infty}{\infty}$ & f \\
\hline Kategori & $\underline{\xi}$ & $\sum_{1}^{\underline{\rho}}$ & $\frac{\xi}{\underline{\rho}}$ & $\underline{\xi}$ & $\frac{\xi}{\equiv}$ & ఖ্ল & ஜి \\
\hline 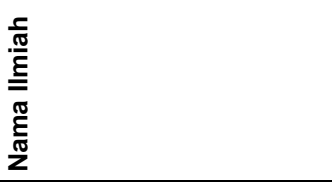 & 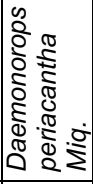 & 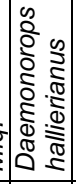 & $\bar{z}$ & 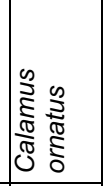 & $\bar{z}$ & 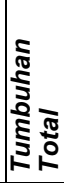 & 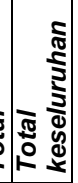 \\
\hline $\begin{array}{l}\bar{\pi} \\
\frac{\pi}{0} \\
\frac{\pi}{\pi} \\
\frac{\pi}{\pi} \\
\text { Z }\end{array}$ & 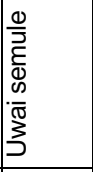 & 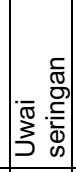 & 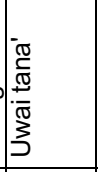 & 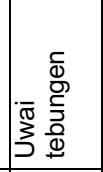 & 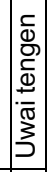 & & \\
\hline$\stackrel{\circ}{z}$ & 冓 & $\begin{array}{l}0 \\
\infty \\
i n\end{array}$ & $\mid \begin{array}{l}\infty \\
\infty \\
i n\end{array}$ & $\begin{array}{l}\infty \\
\infty \\
\infty \\
1\end{array}$ & $\begin{array}{l}\mathbb{8} \\
\infty \\
10\end{array}$ & & \\
\hline
\end{tabular}


Ringkasan jumlah species per kategori:

Binatang

Burung

32

Cacing

Ikan

50

Jamur

21

Reptil

28

Serangga

18

Siput

Tumbuhan

389

$\mathrm{Yu}$ (Crustaceae)

Total

589 
Lampiran 2. Jumlah Jenis Hasil Bumi yang Dipanen Rata-rata Per KK Per Desa

\begin{tabular}{lrcr}
\hline Jenis hasil bumi & Apau Ping & Lg. Alango & Pujungan \\
\cline { 2 - 4 } & 27 & 35 & 23 \\
\hline Pertanian & 12 & 10 & 8 \\
Buah-buahan & 25 & 25 & 17 \\
Sayuran & 9 & 16 & 10 \\
Ikan & 10 & 13 & 10 \\
Kayu & 11 & 14 & 9 \\
Binatang & 7 & 9 & 6 \\
Bambu \& rotan & 10 & 12 & 4 \\
Obat dan kesehatan kulit & 9 & 10 & 6 \\
Bumbu & 10 & 11 & 6 \\
Daun a/ & 4 & 5 & 5 \\
Macam b/ & 1 & 4 & 4 \\
Sagu & 7 & 8 & 4 \\
Tali c/ & 5 & 6 & 2 \\
Bahan upacara & 0 & 1 & 0 \\
Kain dari kulit kayu & 4 & 11 & 7 \\
Serangga & 5 & 4 & 5 \\
Pewarna & 156 & 194 & 126 \\
Total & & & \\
\hline
\end{tabular}


Lampiran 3. Persen Jenis Hasil Bumi yang Dipanen Liar Rata-rata Per KK Per Desa

\begin{tabular}{lrrr}
\hline Jenis hasil bumi & Apau Ping & $\begin{array}{c}\text { Lg. Alango } \\
(\%)\end{array}$ & Pujungan \\
\hline Pertanian & 2 & 2 & 1 \\
Buah - buahan & 38 & 30 & 17 \\
Sayuran & 79 & 85 & 72 \\
Ikan & 100 & 99 & 100 \\
Kayu & 94 & 94 & 95 \\
Binatang & 100 & 100 & 100 \\
Bambu \& rotan & 99 & 99 & 95 \\
Obat dan kesehatan kulit & 36 & 43 & 37 \\
Bumbu & 73 & 73 & 70 \\
Daun a/ & 66 & 67 & 48 \\
Macam b/ & 93 & 81 & 84 \\
Sagu & 0 & 16 & 19 \\
Tali c/ & 96 & 92 & 88 \\
Bahan upacara & 58 & 44 & 64 \\
Kain dari kulit kayu & 0 & 100 & 0 \\
Serangga & 100 & 100 & 100 \\
Pewarna & 100 & 98 & 100 \\
\hline
\end{tabular}

Catatan:

a/ daun untuk bungkus, daun atap, dan daun untuk kerajinan.

b/ madu, getah, racun, dan empedu

c/ tali dan bahan pengikat. 
Untuk lebih memahami dampak perusakan hutan terhadap masyarakat lokal, kami melaporkan mengenai penggunaan hutan dari segi ekonomis dan budaya di tiga desa di Kecamatan Pujungan, Kalimantan Timur. Kami menunjukkan bagaimana kelompok suku Kenyah sangat tergantung pada hutan untuk semua keperluan rumah tangga dan untuk mempertahankan sumber daya alam seperti air dan kesuburan tanah. Kami menunjukkan keterkaitan antara hutan dengan budaya Kenyah dan mempelajari aturan lokal mengenai penggunaan sumber daya hutan, termasuk konsep tana' ulen. Studi ini menyimpulkan bahwa walaupun ada kebijakan yang memungkinkan pengelolaan hutan oleh adat, kebijakan ini tetap harus diaplikasikan secara formal di wilayah hutan tersebut. 